\title{
Insights into the Assembly of Arctic Alaska: Provenance and Geochemical Data from the Doonerak Fenster and Endicott Mountains Allochthon
}

\author{
William Patrick Frier
}

Follow this and additional works at: https://researchrepository.wvu.edu/etd

\section{Recommended Citation}

Frier, William Patrick, "Insights into the Assembly of Arctic Alaska: Provenance and Geochemical Data from the Doonerak Fenster and Endicott Mountains Allochthon" (2017). Graduate Theses, Dissertations, and Problem Reports. 5625.

https://researchrepository.wvu.edu/etd/5625

This Thesis is protected by copyright and/or related rights. It has been brought to you by the The Research Repository @ WVU with permission from the rights-holder(s). You are free to use this Thesis in any way that is permitted by the copyright and related rights legislation that applies to your use. For other uses you must obtain permission from the rights-holder(s) directly, unless additional rights are indicated by a Creative Commons license in the record and/ or on the work itself. This Thesis has been accepted for inclusion in WVU Graduate Theses, Dissertations, and Problem Reports collection by an authorized administrator of The Research Repository @ WVU. For more information, please contact researchrepository@mail.wvu.edu. 


\title{
Insights into the assembly of Arctic Alaska: Provenance and geochemical data from the Doonerak fenster and Endicott Mountains allochthon
}

William Patrick Frier

\author{
Thesis submitted \\ to the Eberly College of Arts and Sciences \\ at West Virginia University
}

In partial fulfillment of the requirements for the degree of

\author{
Masters of Science in \\ Geology \\ Jaime Toro, Ph.D., Chair \\ Helen Lang, Ph.D. \\ Kenneth Brown, Ph.D. \\ Department of Geology and Geography \\ Morgantown, West Virginia \\ 2017
}

Keywords: Arctic Alaska Terrane, Doonerak Fenster, Arctic Alaska Chukotka Microcontinent, Endicott Mountains Allochthon, Provenance, Detrital Zircon, Geochronology, Geochemistry, Major Elements, Trace Elements, Rare Earth Elements 


\begin{abstract}
INSIGHTS INTO THE ASSEMBLY OF ARCTIC ALASKA: PROVENANCE AND GEOCHEMICAL DATA FROM THE DOONERAK FENSTER AND ENDICOTT MOUNTAINS ALLOCHTHON
\end{abstract}

\title{
William Patrick Frier
}

The Doonerak fenster of the central Brooks Range contains the Apoon assemblage, a suite of Early Paleozoic mafic-to-intermediate volcanic and siliciclastic rocks. The fenster exposes deep structural levels of the Brooks Range between regions of Laurentian and nonLaurentian origin in Arctic Alaska. During the Mesozoic to Cenozoic formation of the Brooks Range, Upper Devonian to Triassic siliciclastic and carbonate rocks of the Endicott Mountains allochthon were thrusted northward and juxtaposed over the top of this volcanic suite.

New geochemical data indicates that the Apoon assemblage formed as part of an island arc complex. The assemblage contains basaltic-to-andesitic rocks with diverse textures, including pillow basalts and cross-cutting dikes and sills. Enrichment in large ion lithophile elements (e.g. $\mathrm{Cs}, \mathrm{Rb}, \mathrm{Ba}, \mathrm{Th}$ ), depletion in high field strength elements (e.g. Nb, P, Zr, Ti), and chondritenormalized rare-earth element (REE) trends within the Apoon volcanics are consistent with formation in an island arc setting and corroborate previous work.

Detrital zircon spectra from volcaniclastic portions of the Apoon assemblage show a prominent unimodal 440-530 Ma population centered on 504 Ma with only minor populations potentially derived from Laurentia. The siliciclastic units unconformably overlying the Apoon assemblage (Ellesmerian sequence) and those of the Endicott Mountains allochthon mostly lack detritus from this 504 Ma population and are instead dominated by 400-440 Ma populations centered on $\sim 420 \mathrm{Ma}$. While this is dissimilar from the Apoon assemblage, detritus of this age is common in rocks of the Canadian Arctic, Svalbard, and eastern Greenland and is associated with the Caledonian orogeny.

The coexistence of Caledonian detritus alongside 800 - 550 Ma populations within samples from the northern margin of the fenster also indicates a connection to the Timanian orogen of northern Baltica. The youngest portions of the Apoon assemblage also show significant Laurentian and Caledonian age detritus. This shift in provenance could be explained by the closure of an oceanic basin, providing newly integrated sediment pathways. Collectively, evidence presented here indicates that the Apoon assemblage formed as part of an island arc, which initially formed in a relatively isolated geographic position and received detritus from mostly proximal sources (single unimodal 504 Ma population). This arc progressively approached and eventually docked onto the margin of northwest Laurentian during closure of the northernmost Iapetus Ocean, eventually amalgamating regions of Laurentian and non-Laurentian origin. Thus, the Doonerak fenster preserves an island arc complex and marks the location of a Paleozoic suture between Laurentian and non-Laurentian portions of Arctic Alaska. 


\section{ACKNOWLEDGEMENTS}

Foremost among those I would like to thank is my advisor, Dr. Jaime Toro. Jaime is a passionate teacher, encouraging advisor, caring family man, and genuinely good person. He pushes his advisees to think for themselves and places them in environments that encourage them to develop the skills needed to be successful as students of both geology and life. He is pleasant to be around and approaches life with an attitude that is simultaneously easy-going, hardworking, and contagiously positive. He also plays soccer well and makes great book suggestions.

I owe significant credit to Benjamin Johnson, my office mate and pseudo-advisor. Ben is an extremely generous and kind man. He shared his ideas and experiences with me without complaint, even when I blatantly interrupted his work. Over the past few years, Ben helped me see a path toward completing the document you are now reading all while working to complete his own $\mathrm{PhD}$. His wit and sharp intellect also made our cave-like basement office an engaging and fun place to work. He and his partner, Patricia, are fine people who deserve the best.

Greg Hammond joined me in the Brooks Range as my field assistant before starting his own master's project, focused on the deformational and thermal history of rocks in the vicinity of Doonerak. I feel like I got to know a different side of Greg during our one-on-one fourteen day stint under Alaska's midnight sun. He is an interesting man whom I'm sure will be very successful in life. I wish him the best as he continues to think about the Doonerak fenster.

Drs. Helen Lang and Kenny Brown were kind enough to share their intellect and provide useful critiques as committee members. Helen and Kenny both exhibit unique and fun senses of humor. Helen is a signpost of our department, respected by all who know her, and a pleasure when our department goes to the pub on Fridays. Kenny (of Earth C130) was extremely kind, humorous, passionate, and selfless as he helped me understand geochemistry. I also served as his TA, which was a fun and educational experience for me as well as our students.

Dr. David Barbeau of the University of South Carolina assisted with all aspects of the detrital zircon LA-ICP-MS analysis. Dave is an extremely nice guy and he was a huge help with the DZ data acquisition and processing. He is a laser ablation guru. One DZ sample (J1415) was provided by Justin Strauss, a friend and colleague of Ben's, who is also a great guy.

A. Rizzo, C. Khoury, P. Goodling, and G. Morris helped remind me of my real path. Thanks is also due to many WVU grad students for being encouraging and passionate friends in the department. We have a truly lively group here including A. Andeskie, E. Bausher, A. Delisle, L. Eichenlaub, C. Findlay, B. Gaschot, J. Knapp, W. Martin, J. Pilweski, and M. Reed.

Lastly, I owe thanks to my family: to my father for encouraging me to pursue engaging and emotionally sustaining career paths, to my mother for her kindness and eternal support (as well as access to a washing machine), and to my siblings - Timmy and Kate - who both exhibit strength and fortitude of character in ways that I often lack. They are both remarkable people, but show it in very different ways. Recently we all gathered to celebrate my sister's wedding (hey Craig!). Perhaps because it is so rare, I've come to appreciate opportunities to spend time with my family more and more throughout graduate school. It was particularly lovely to celebrate such a happy occasion together.

Thank you, folks. Hopefully being associated with me and this document isn't too embarrassing for you all.... It might be.... 
To my niece and nephew:

Ashby Cole Frier and Quinn Andrew Frier.

If you grow up and decide you want to go camping in Alaska, let me know. I'm the uncle for that. 


\section{TABLE OF CONTENTS}

FIGURES $v i$

1. INTRODUCTION --

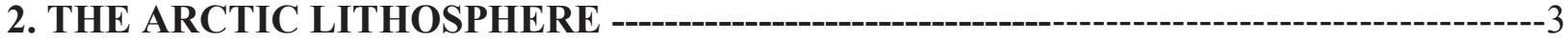

2.1 The Arctic Oceanic Realm ----o---on

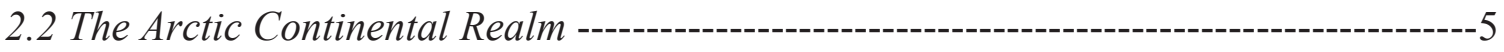

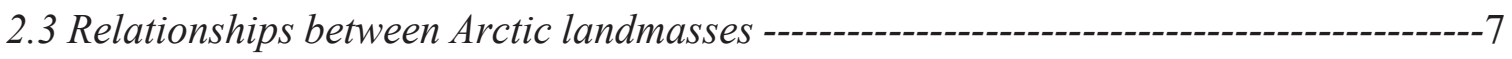

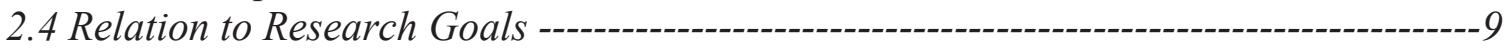

3. THE DOONERAK FENSTER - LOCATION AND GEOLOGIC SETTING ----------10

3.1 Terranes and Subterranes - Context within Arctic Alaska ---_----10

3.2 Pertinent Stratigraphy -----------------------------------------------------------13

3.3 Overview of orogenic events in northern Alaska and the Arctic ------------------------16

3.4 The Doonerak fenster: location and basic relationships --_c--on

3.5 The Apoon Assemblage - Lower Paleozoic volcanic rocks -------------------------21

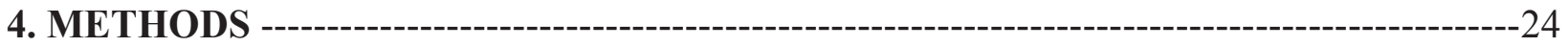

4.1 Methodological goals --------------------------------------------------24

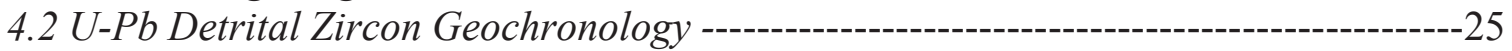

4.3 Whole Rock Volcanic Geochemistry ----_-

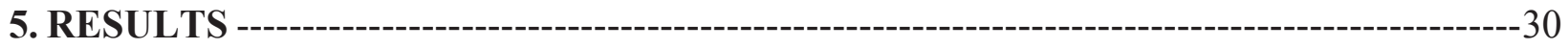

5.1 Field Relationships, sample collection, and lithologic characteristics ---------------30

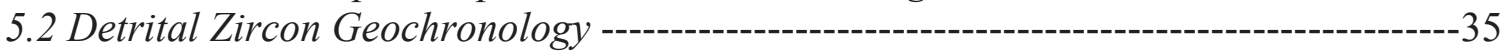

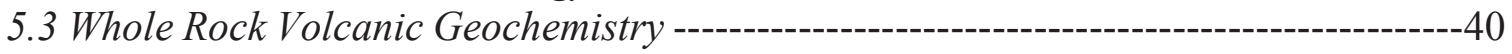

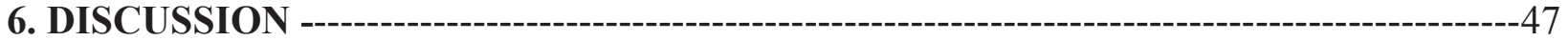

6.1 Field Relations and Overview ------------------------------------------------47

6.2 The Beaucoup and Hunt Fork Formations: Hanging wall of the Awawk Thrust ------50

6.3 The Apoon Assemblage and Endicott Group --------------------------------53

6.4 Circum-Arctic Comparisons and Paleotectonic Setting of the Apoon Assemblage ---55

7. CONCLUSIONS --

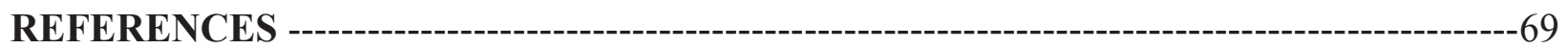

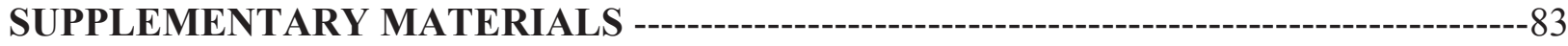

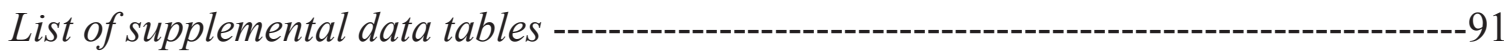




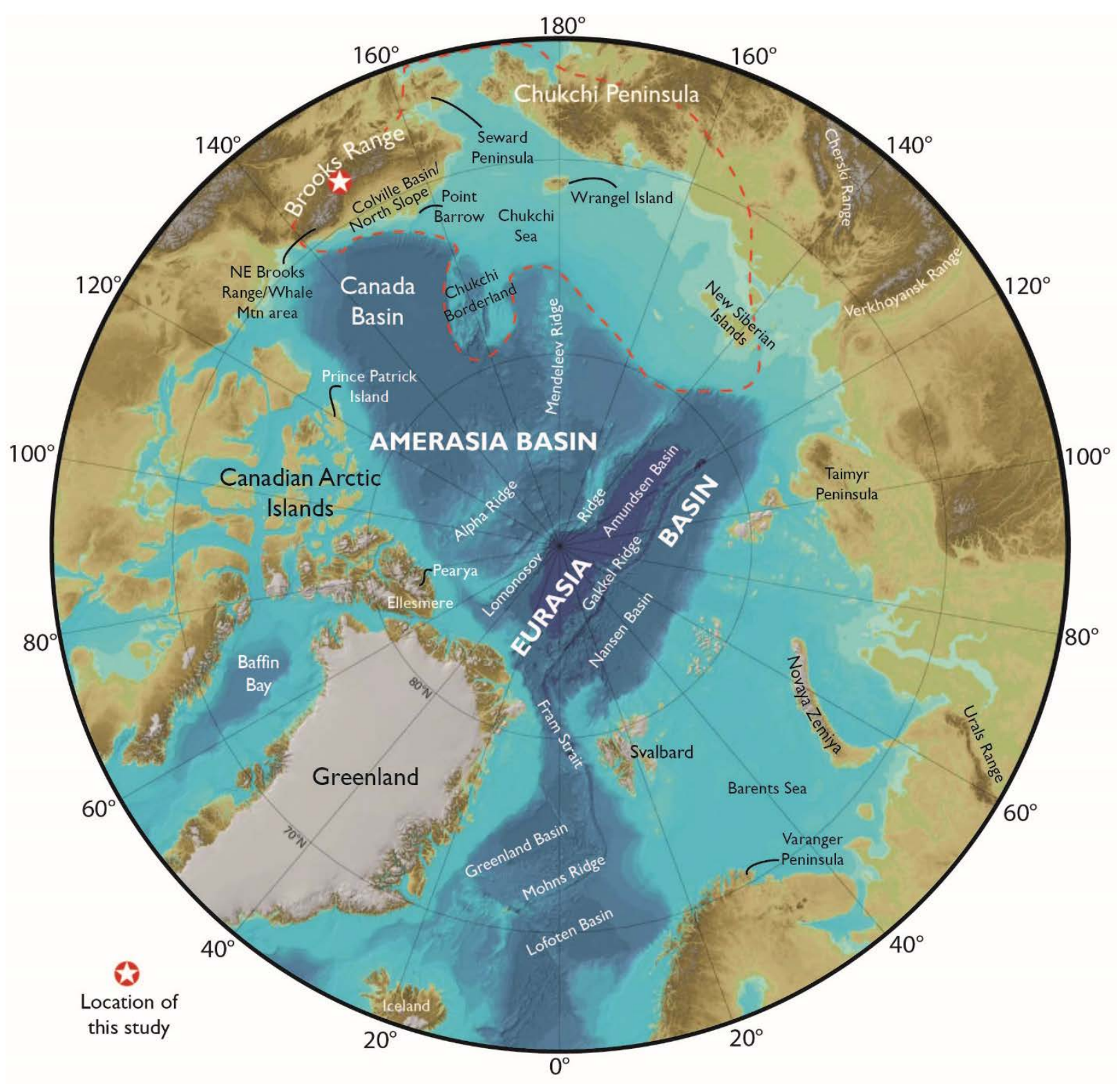

Bathymetric and topographic key (Meters above and below Mean Sea Level)

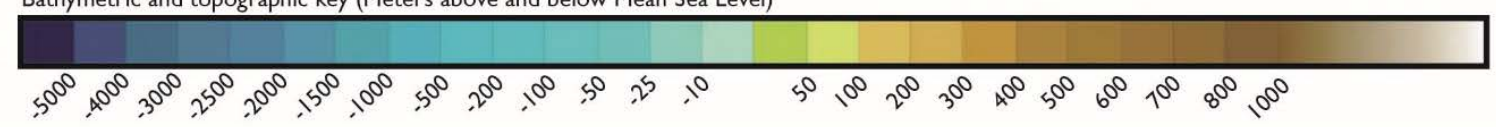

Figure 1: Polar-view index map of the region north of the Arctic Circle showing topography and bathymetry of various physiographic regions (after Jakobsson et al., 2012, Pease et al., 2014). The dashed red line marks the approximate bounds of the Arctic Alaska - Chukotka microplate. The white star outlined in red marks the location of fieldwork for this study. 


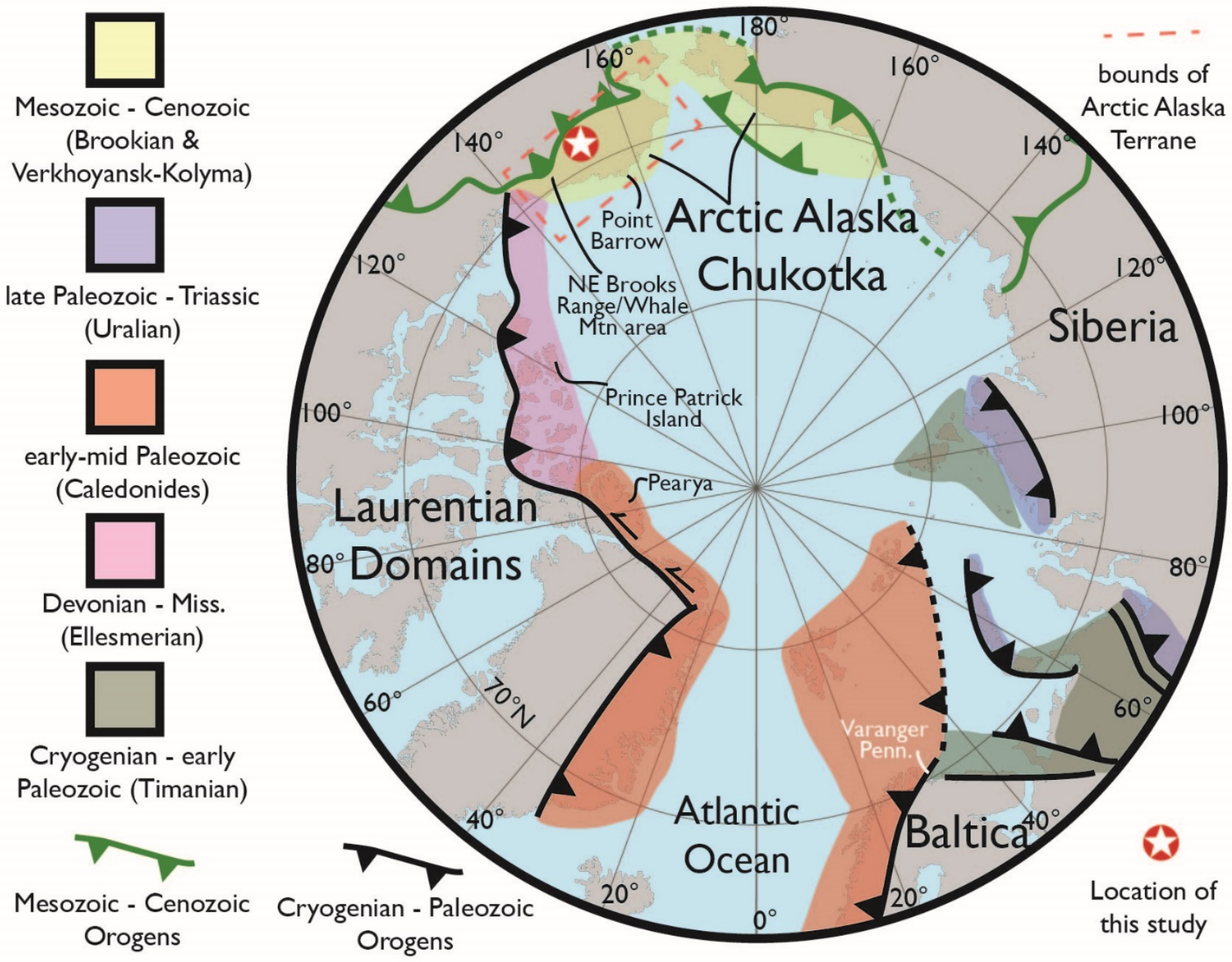

Figure 2: Simplified polar-view map showing the distribution of Proterozoic and Paleozoic orogens in the Arctic region. Modified from Colpron and Nelson (2011) and Strauss et al. (2013). 


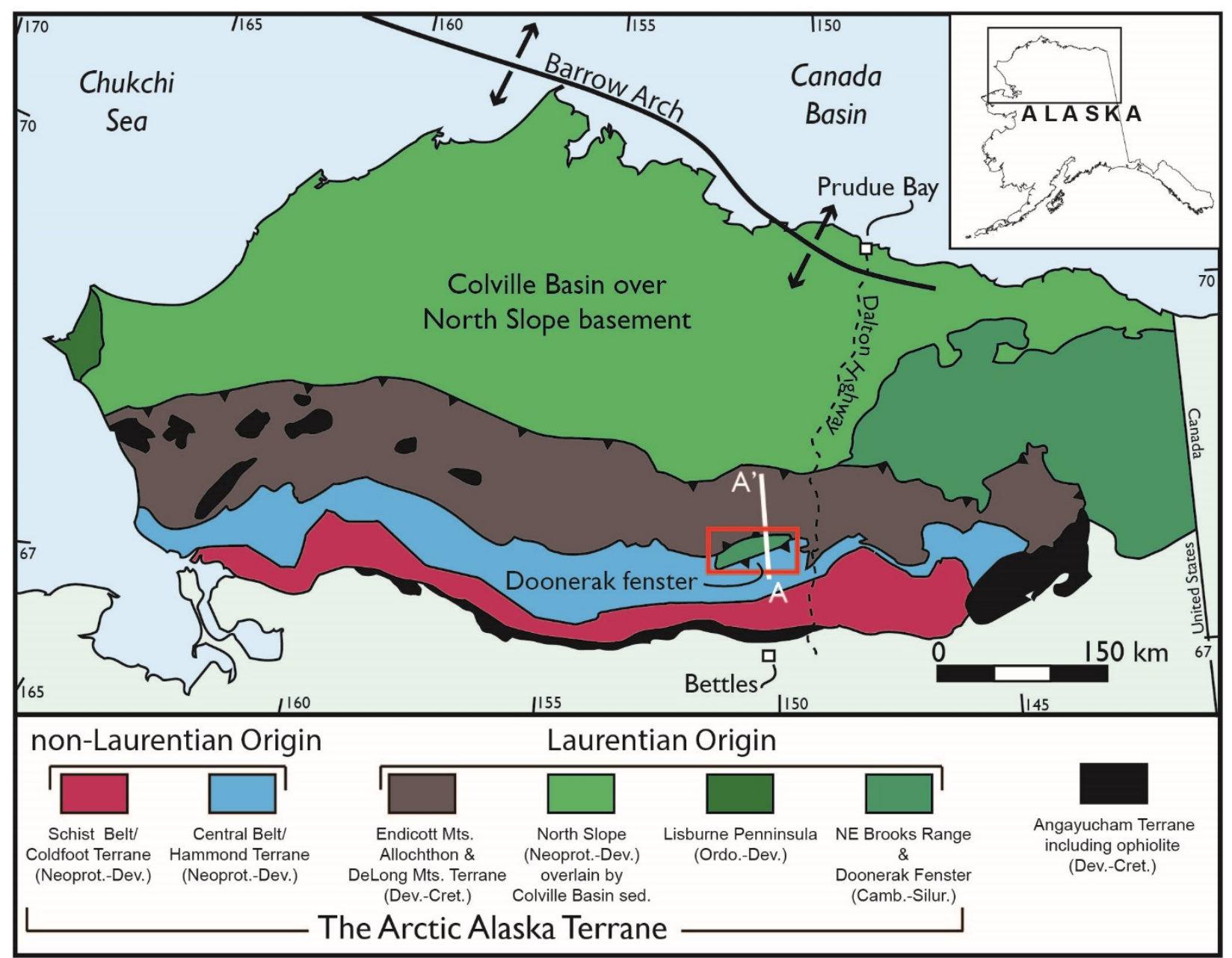

Figure 3: Simplified terrane map of Arctic Alaska colored to show regions of Laurentian and non-Laurentian origin (modified from Moore et al., 1994). Red box marks the location of the Doonerak fenster in the central Brooks Range, which is expanded in Figure 6. Line A-A' corresponds to the cross section in Figure 7. 

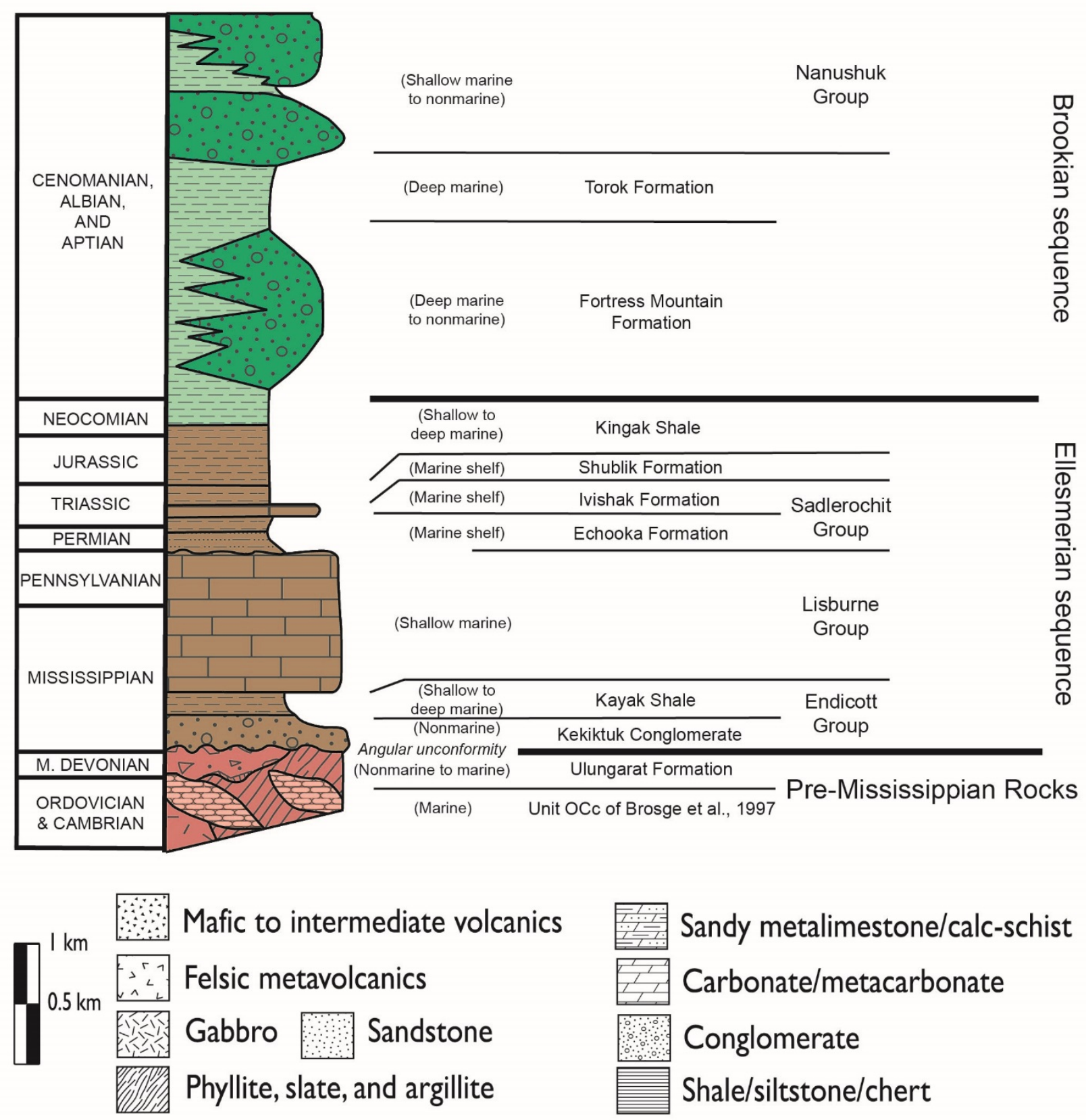

Figure 4: Generalized stratigraphic column of the North Slope portion of the Arctic Alaska terrane (pre-Mississippian rocks and Ellesmerian sequence) and the overlying terrigenous clastics of the Colville Basin fill (Brookian sequence). Column based on the southern portions of the North Slope, located $100 \mathrm{~km}$ north east of the study area. Adapted from Moore et al., (1997). 
S

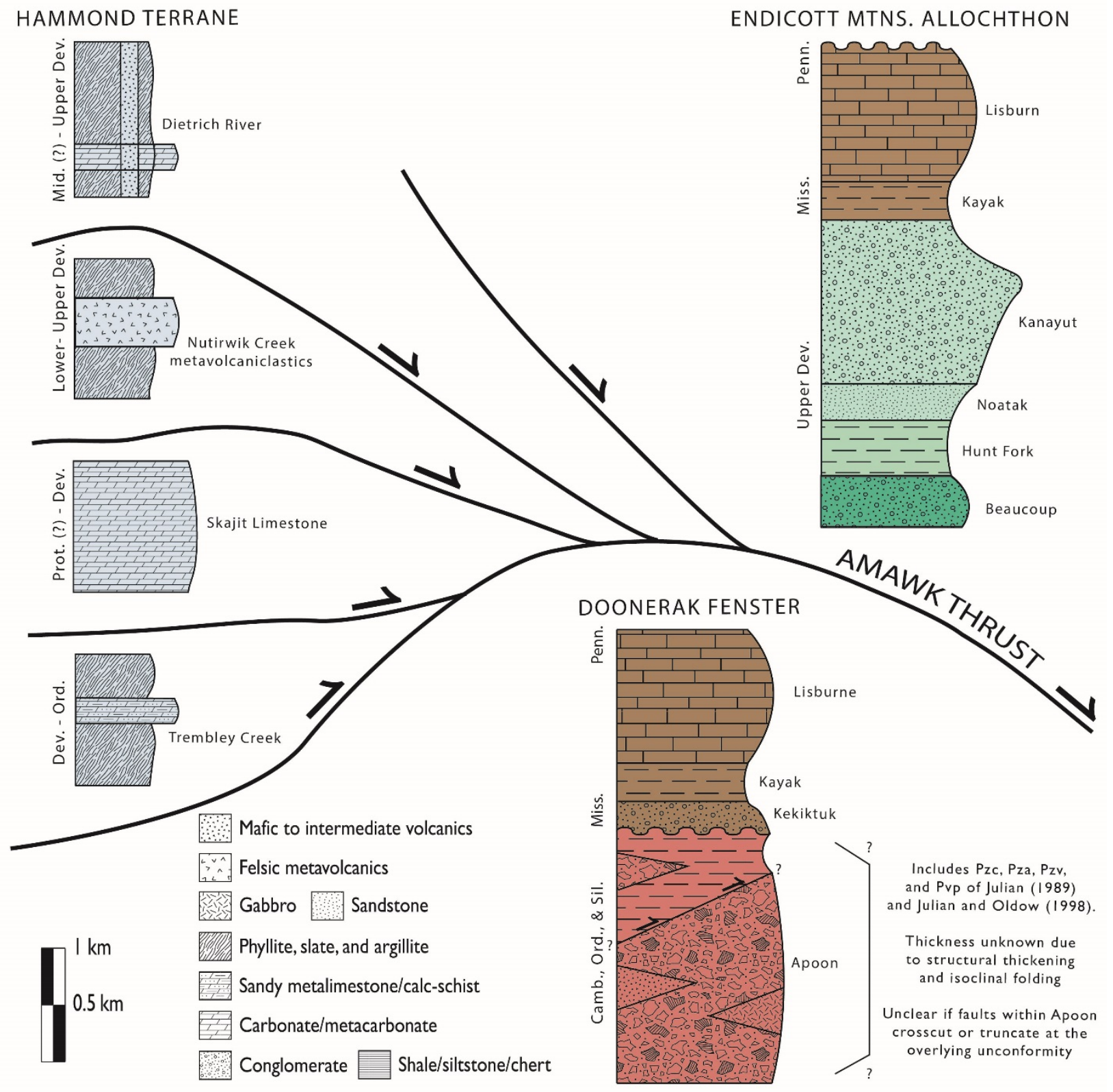

Figure 5: Relative structural positions and stratigraphic relationships of the Hammond subterrane, Endicott Mountains allochthon, and Doonerak fenster in the central Brooks Range. Adapted from Moore et al., (1997) with nomenclature from Julian (1989), Julian and Oldow (1998) and Moore et al., (1997). 


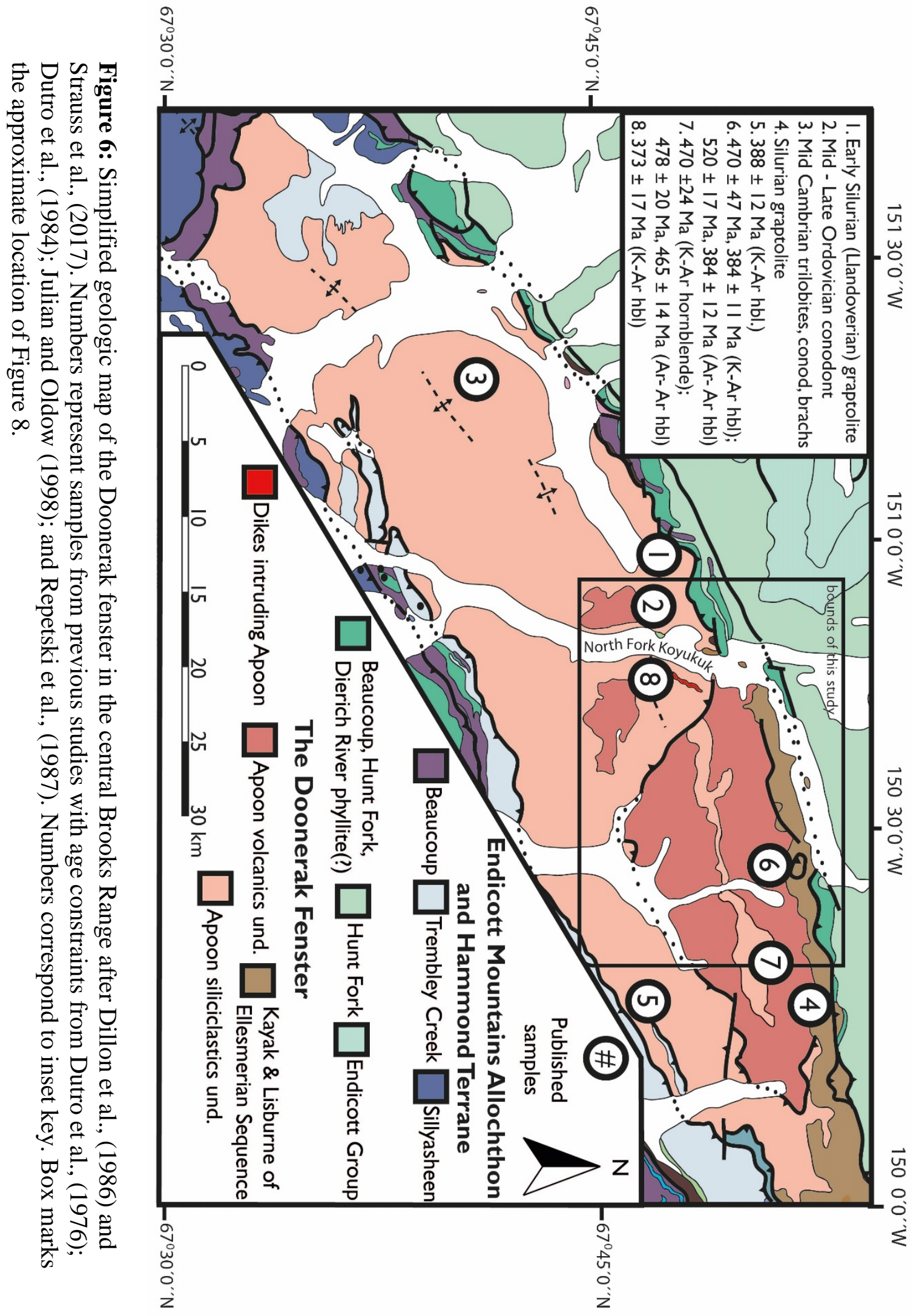




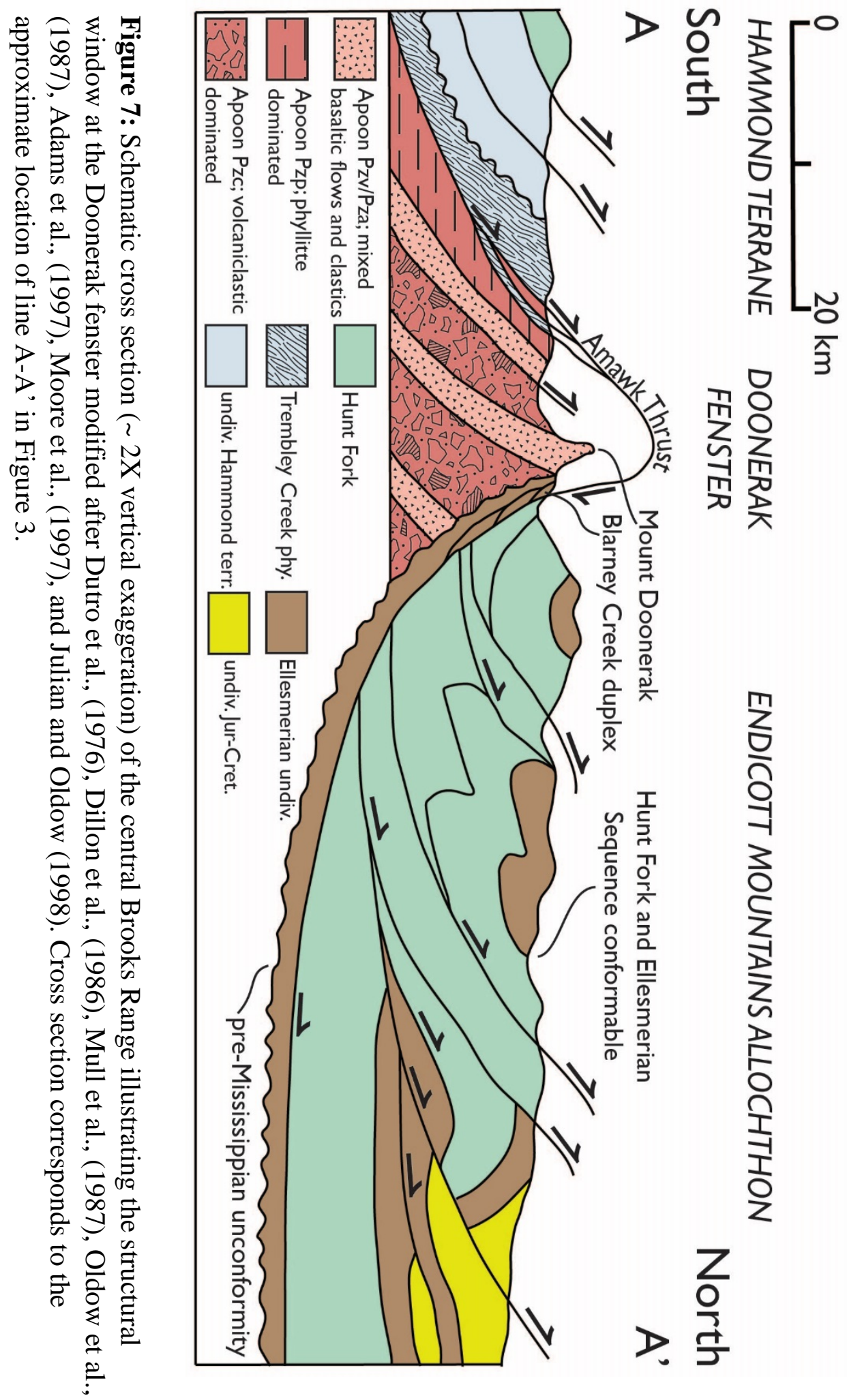




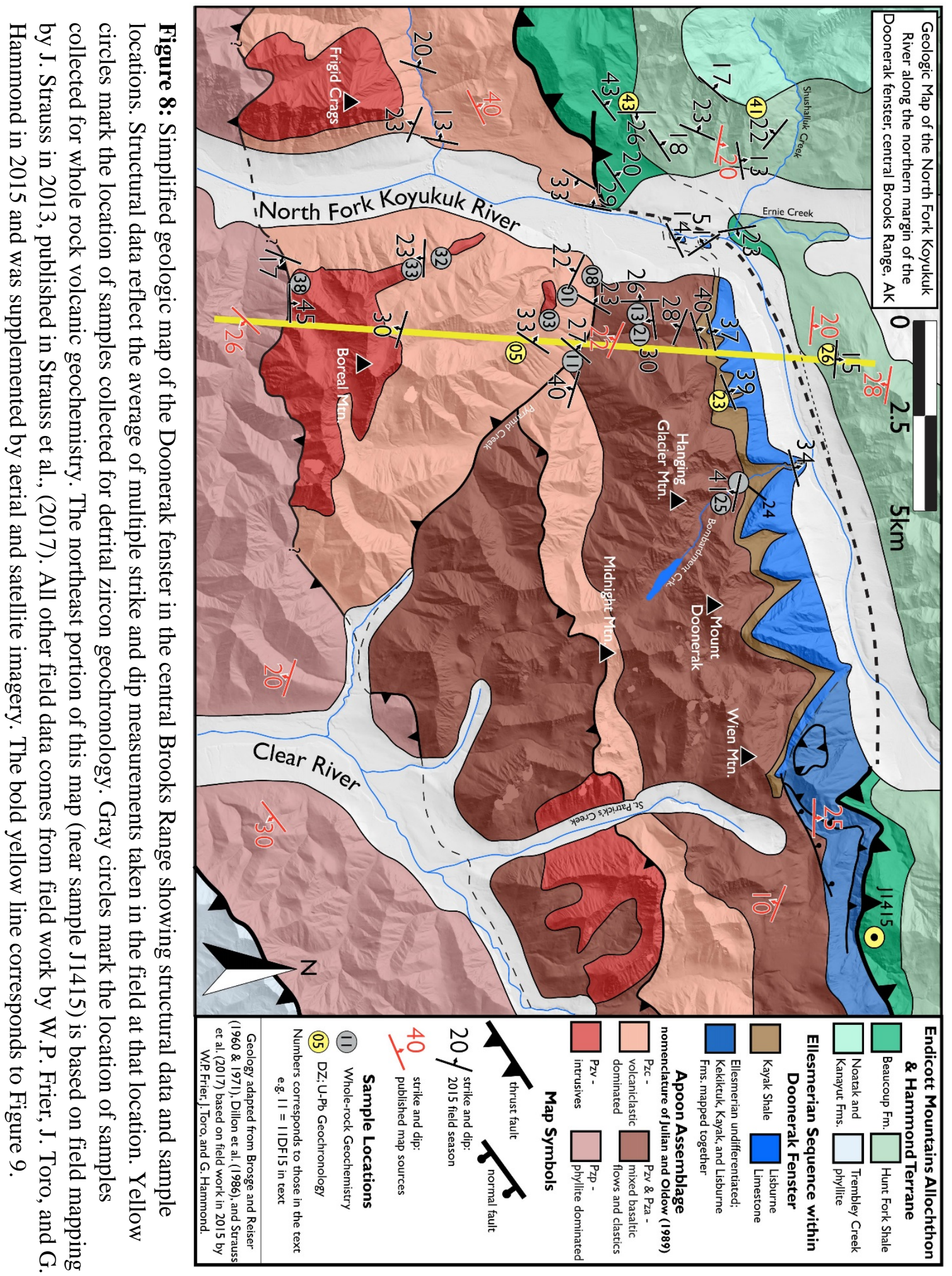




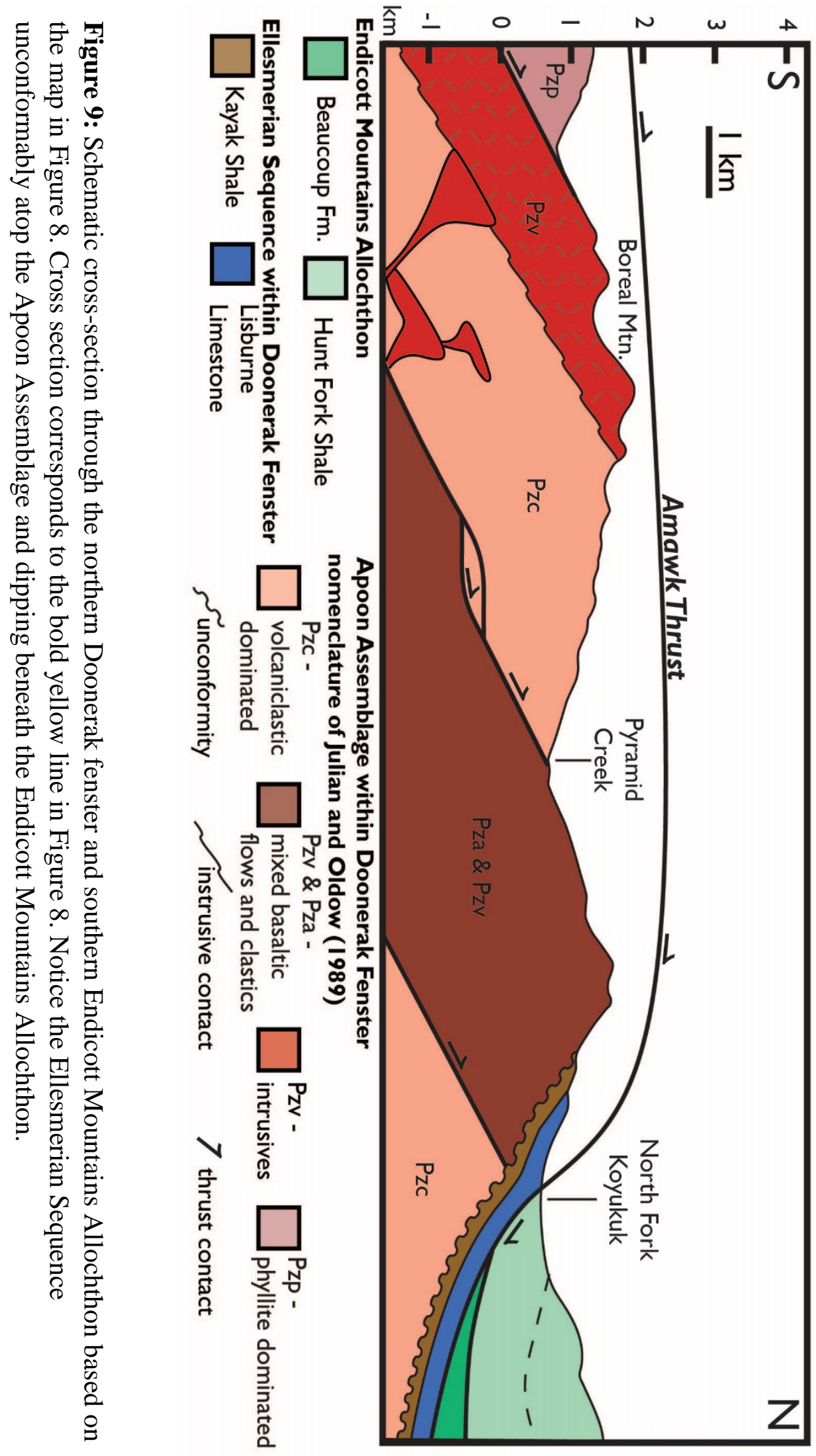




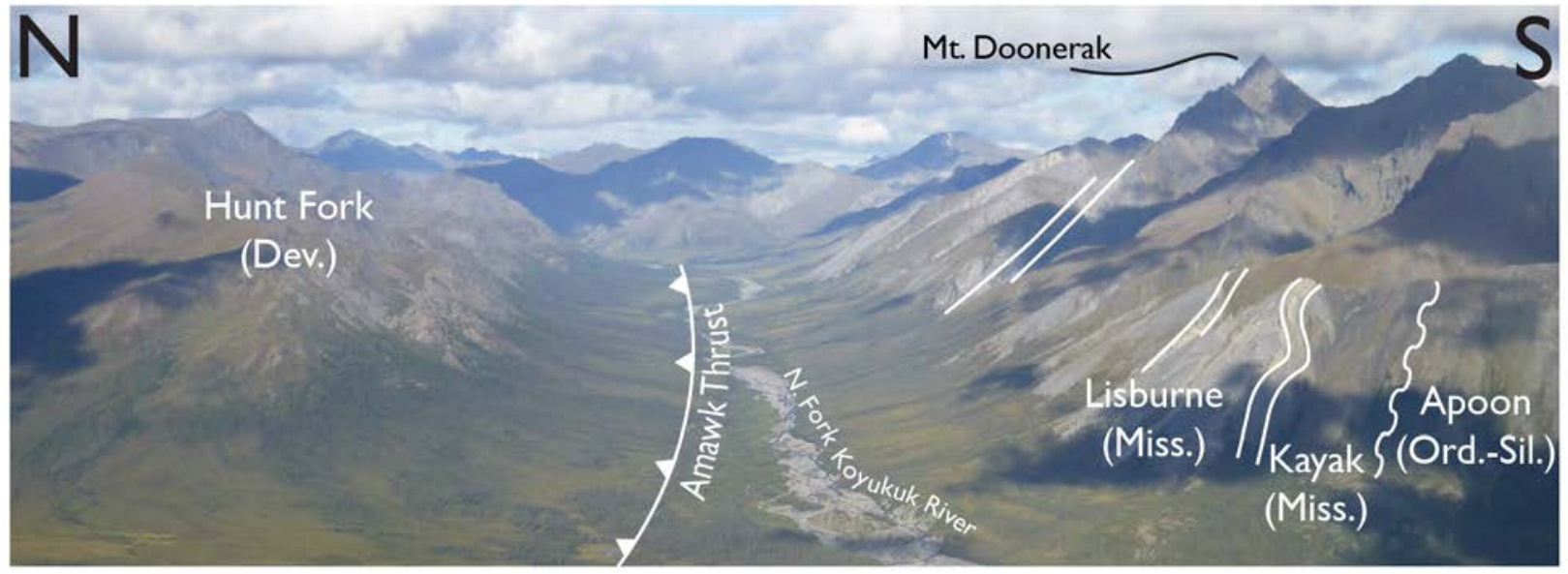

Figure 10: Field photo looking east along the North Fork of the Koyukuk River in the central Brooks Range. To the North (left) side of the image are of rocks of the Endicott Mountains allochthon, the Hunt Fork Shale. To the South (right) side of the image are rocks of the Lisburne Limestone, Kayak Shale (Ellesmerian sequence) and Apoon assemblage (pre-Mississippian basement) of the Doonerak fenster. 

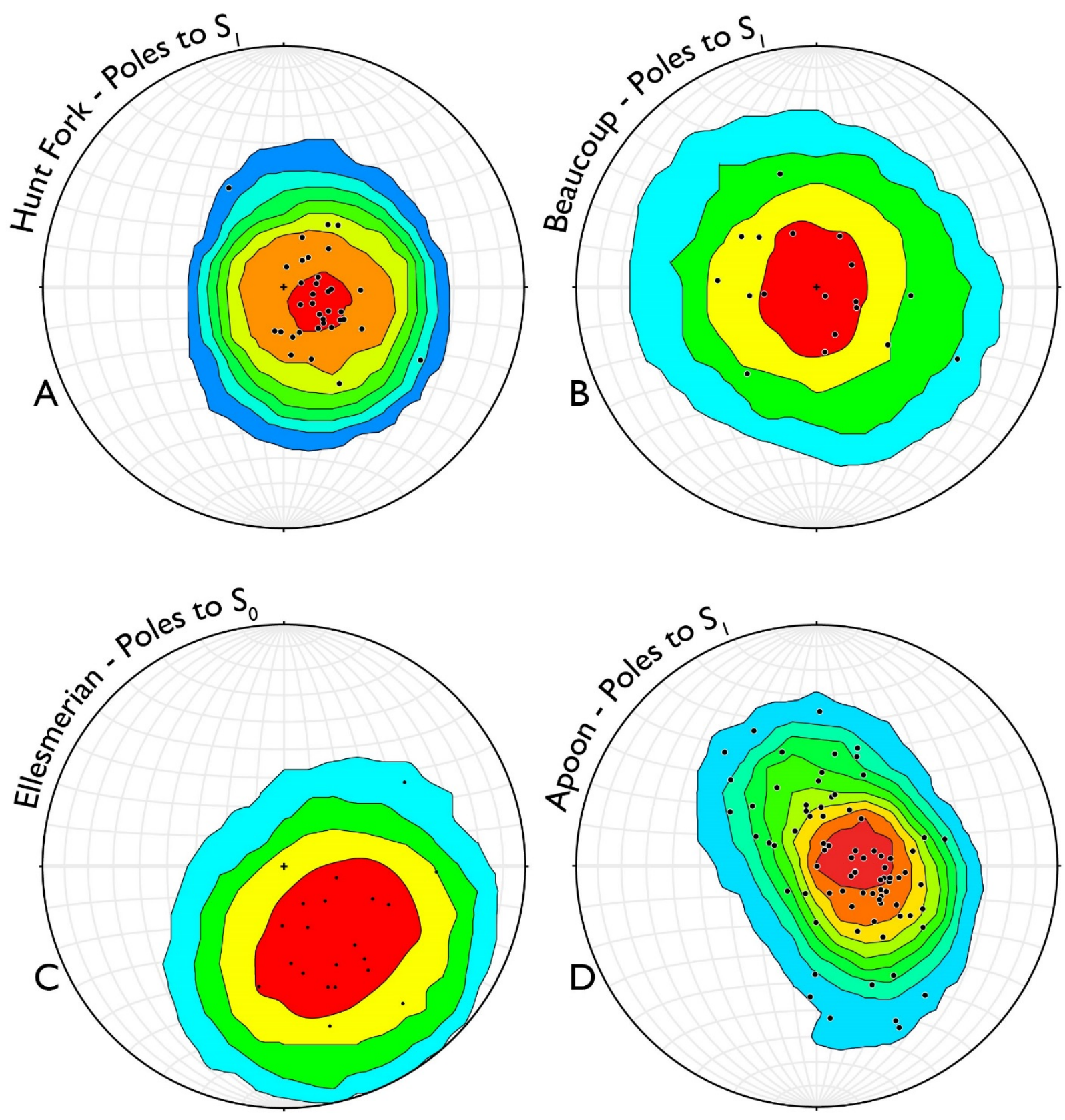

Figure 11: Contoured stereonets showing poles to dominant foliation $\left(\mathrm{S}_{1}\right)$ observed during the 2015 field season and organized based on lithostratigraphic association. In most cases the primary surface corresponds to dominate cleavage $\left(\mathrm{S}_{1}\right)$; however bedding $\left(\mathrm{S}_{0}\right)$ was evident within the Ellesmerian sequence consistently and periodically differentiated from cleavage in other formations. 

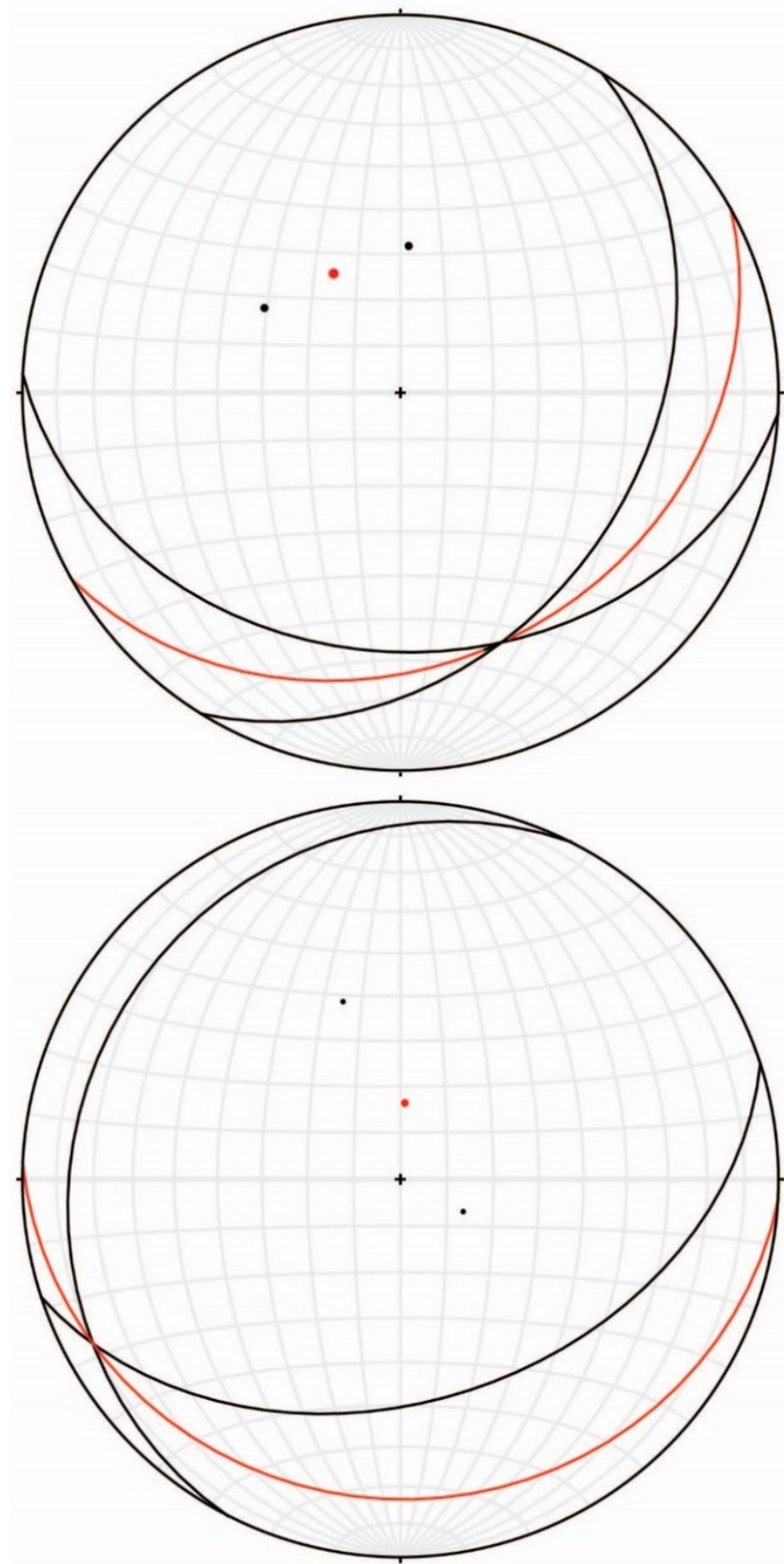

Figure 12: Great circles and their associated poles of bedding around folds observed within the Beaucoup formation, west of the North Fork Koyukuk River in 2015 (shown in black). The inferred fold axes are shown in red with their associated poles (also in red). The attitude of these folds is consistent with the dominant regional trend of Brookian folds. 

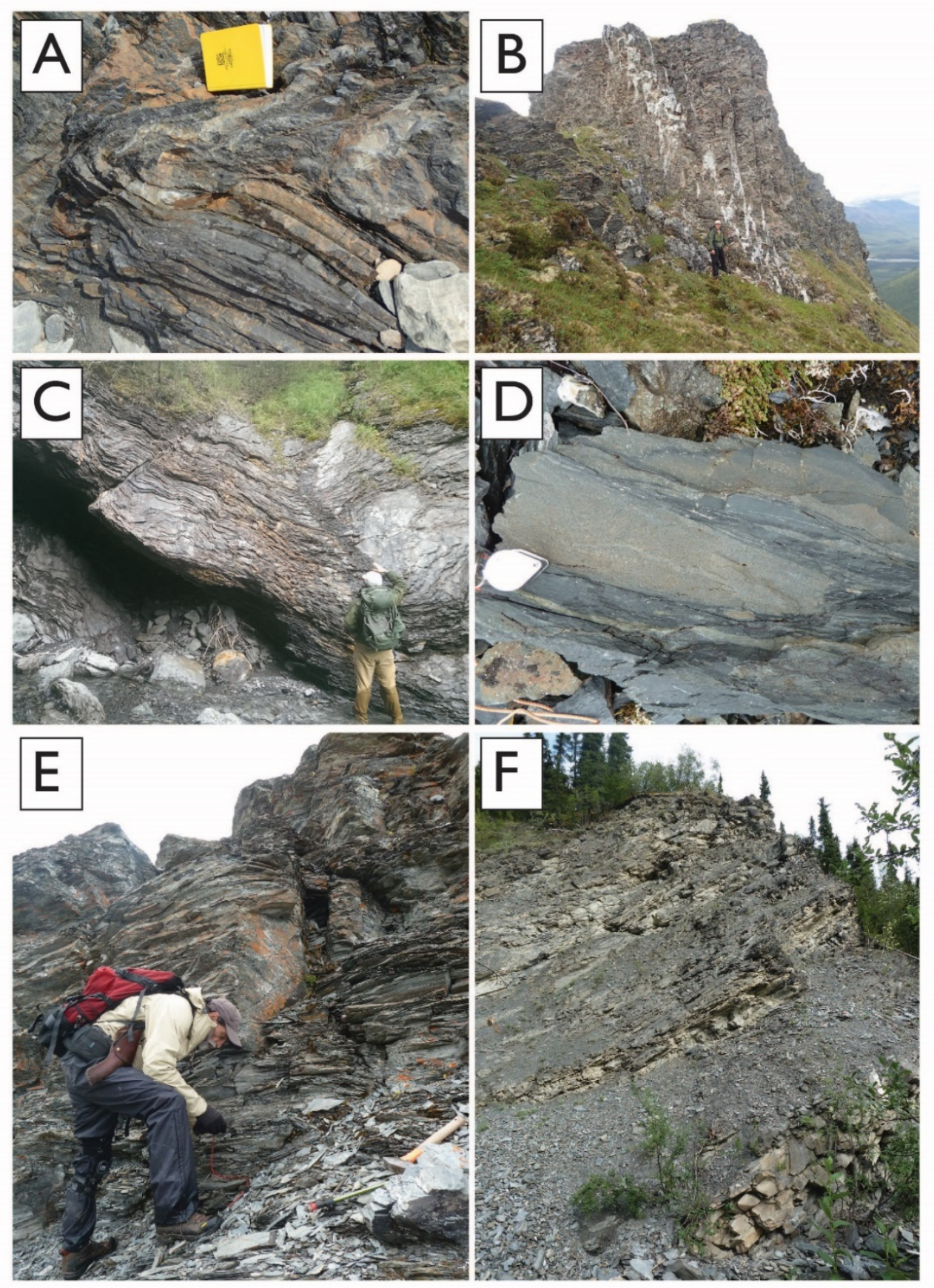

Figure 13: Field photos from clastic/volcaniclastic portions of the Apoon assemblage, Pzc. A outcrop of recumbent isoclinal folds within slate and lithic sandstone along Pyramid Creek. Field book pictured is $19 \mathrm{~cm} \times 12 \mathrm{~cm}$. B - En echelon vein array atop ridge south of Pyramid Creek, defining a small fault zone between slates and tuffs within the Apoon assemblage. Person pictured is $\sim 1.8 \mathrm{~m}$ tall. $\mathrm{C}$ - Broad gently plunging open folds within phyllites of the Apoon assemblage along Pyramid Creek. Person is $\sim 1.8 \mathrm{~m}$ tall. D - Example of fine-to-medium grained lithic sandstone with intermediate slate from ridge south of Pyramid Creek. Hand lens is $\sim 2 \mathrm{~cm}$ in length $\mathrm{E} \& \mathrm{~F}$ - Typical variety among rocks of the Apoon assemblage. Range from fine grained thinly bedded slates and well foliated phyllites to thin-to-medium bedded lithic sandstone interbedded among slates. 

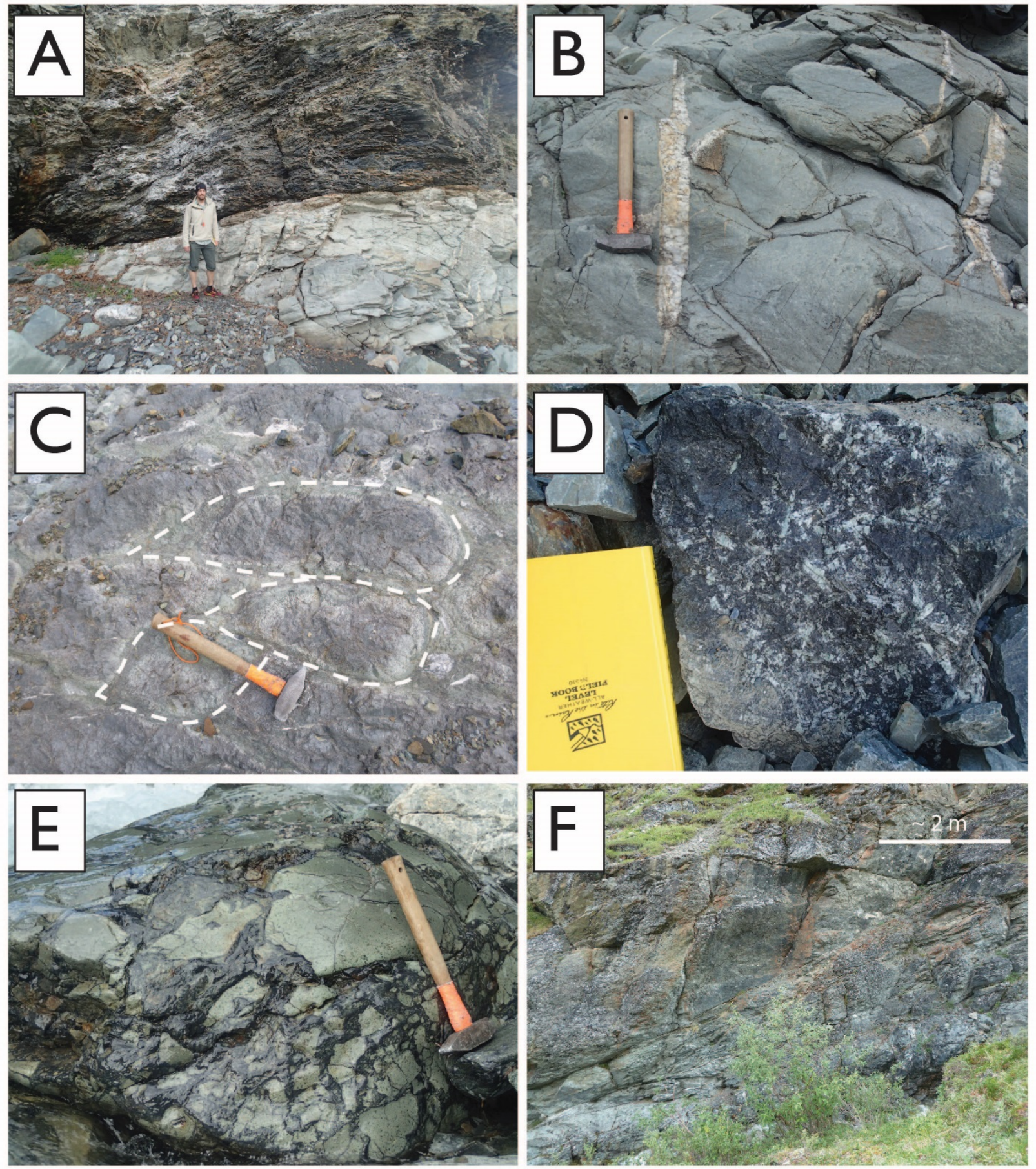

Figure 14: Field photos from volcanic/igneous portions of the Apoon assemblage. A \& B - two images of the same outcrop along Pyramid Creek. Sill of andesite with crosscutting veins of quartz and calcite. Hammer pictured has a $\sim 30 \mathrm{~cm}$ handle. Person pictured is $\sim 1.8 \mathrm{~m}$ tall. $\mathrm{C}$ aphanitic basalt pillows from Bombardment Creek. D - Porphyritic basaltic andesite from Boreal Mountain with large laths of plagioclase. E - Aphanitic greenstone found along Bombardment Creek (not in place) which likely formed as a basaltic flow top breccia. F - Fine grained basaltic greenstone north of Pyramid Creek with thoroughgoing brittle fractures. 

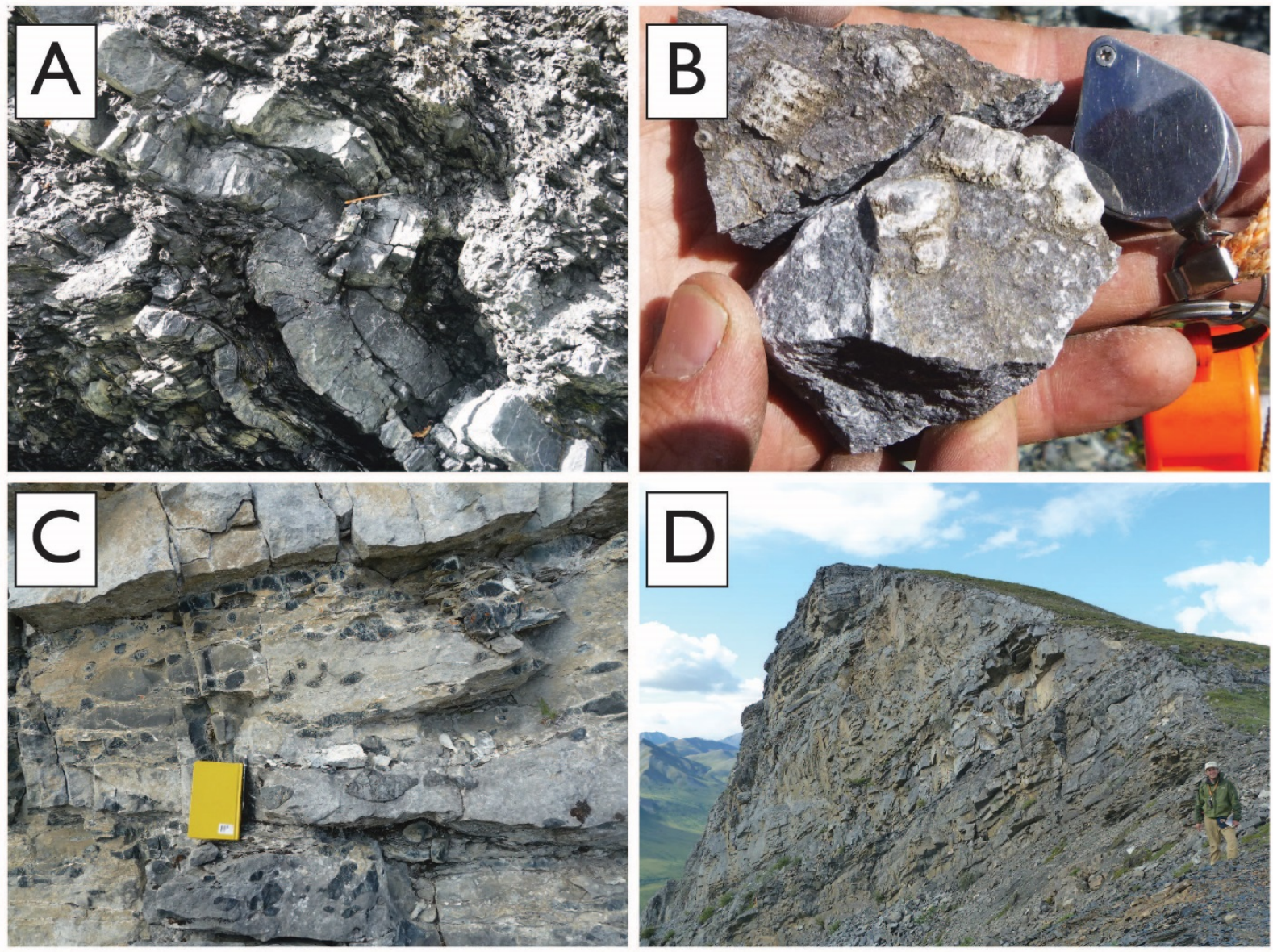

Figure 15: Field photos from the Ellesmerian Sequence within the Doonerak fenster. A - folded limestone and shale within the Kayak Shale along Bombardment Creek. Pencil for scale is $\sim 11$ $\mathrm{cm}$ in length. B - Crinoids within the Kayak Shale. Hand lens is $\sim 2 \mathrm{~cm}$ in length. $\mathrm{C}$ - Nodular chert within thickly-bedded limestone of the Lisburne formation. Field book is $19 \mathrm{~cm}$ long. D Outcrop of thickly-bedded Lisburne Limestone south of the North Fork Koyukuk River in the northern portion of the field area. Person pictured (far right) is $\sim 1.8 \mathrm{~m}$ tall. 

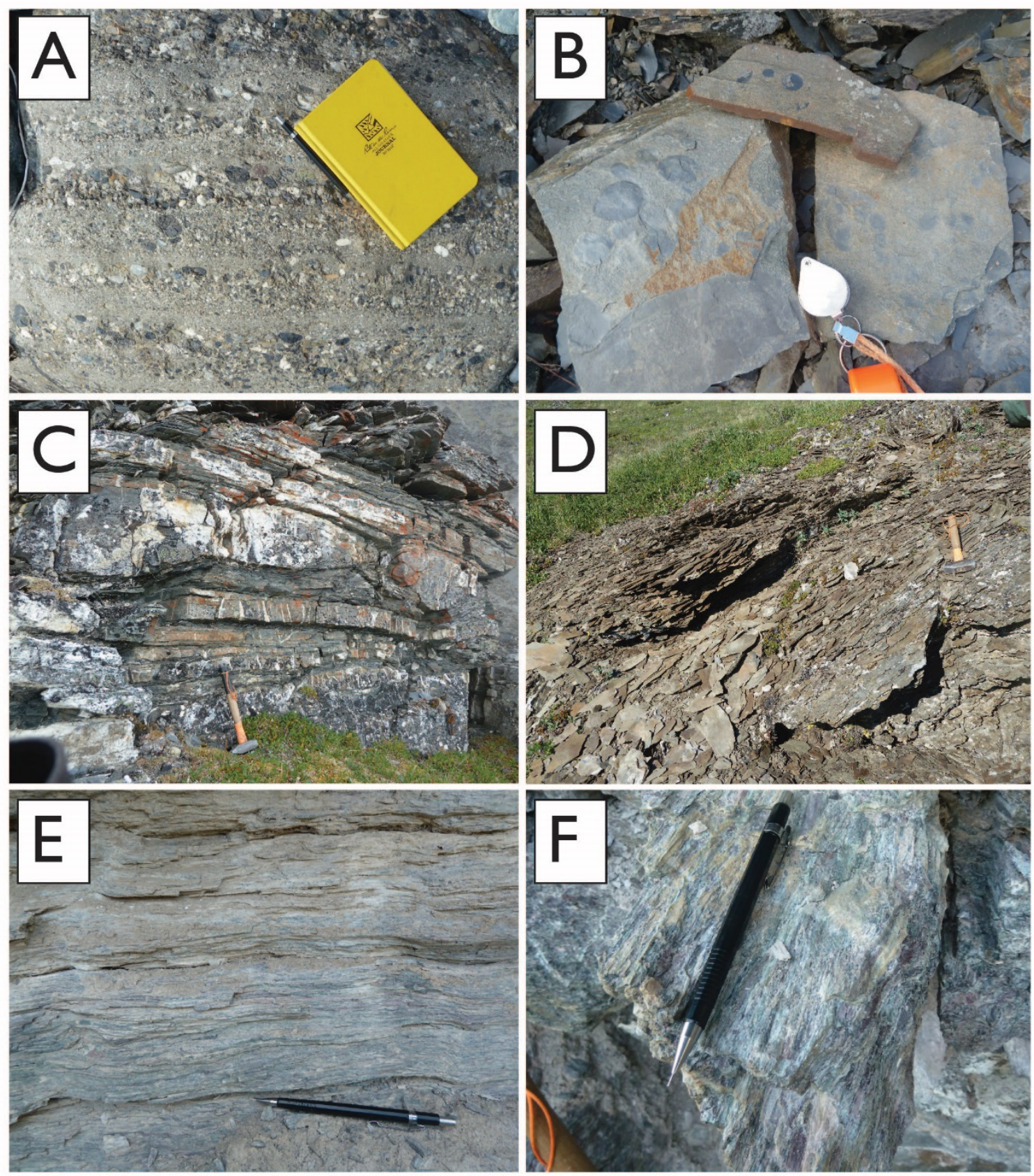

Figure 16: Field photos of other assorted formations. A - Kanayut Conglomerate: example of poorly-sorted quartz and chert pebble conglomerate. B - Hand samples of fine grained lithic sandstone found along the gradational transition from Hunt Fork Shale to Noatak Sandstone, stratigraphically below the Kanayut Conglomerate, northwest portion of map area.. C \& D Hunt Fork Shale - Examples of thin-to-medium bedded outcrop with small calcite filled veins and thinly-bedded, highly-foliated and fissile variety. E \& F - Highly-foliated and sheared greento-purple quartz and chert pebble conglomerate of the Beaucoup formation found just north of the North Fork Koyukuk River. Both photos are from the same outcrop. 


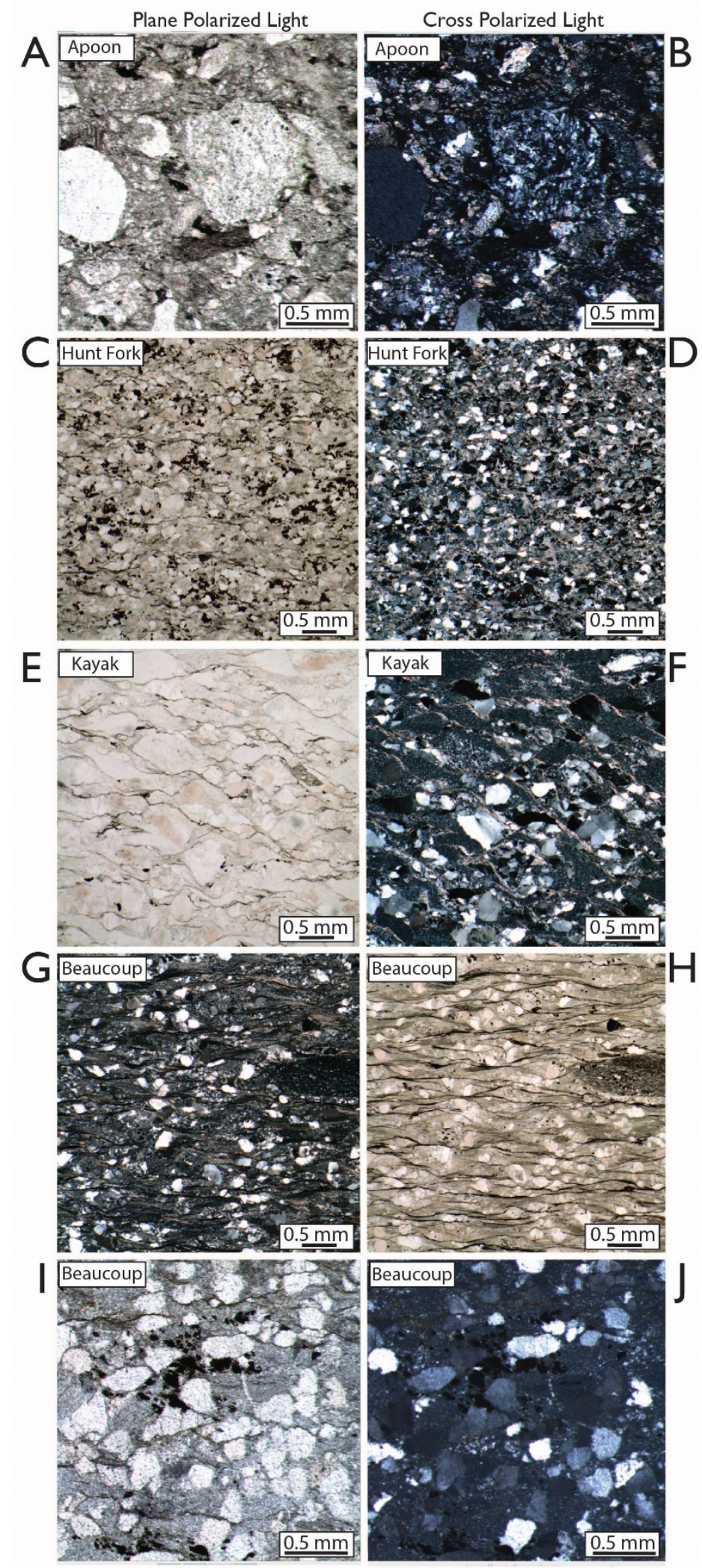

Figure 17: Thin section micrographs of various formations analyzed for detrital zircon geochronology in this study. 

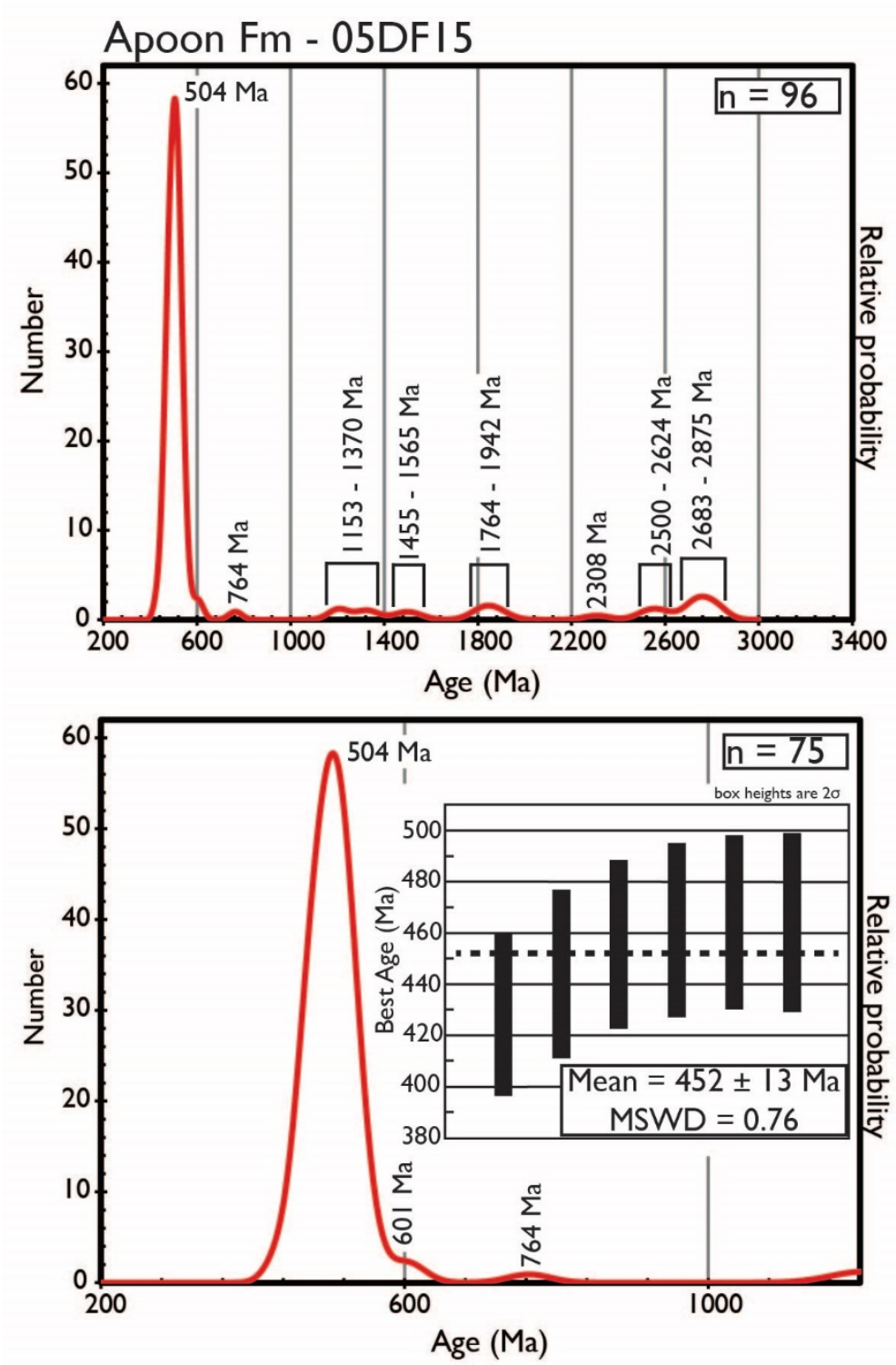

Figure 18: Probability density plot and max depositional age estimation generated from detrital zircon geochronology for sample 05DF15 - Apoon assemblage. See Figure 9 - marked as 05 - for sample location on a map. The top panel shows the entire range of the probability density plot. The lower panel shows a probability density plot generated from only the youngest grains, younger than $1200 \mathrm{Ma}$. Dominate age groupings are labeled. Box heights in the max depositional age figure represent the $2 \sigma$ error on the analysis of that grain. The mean of the youngest population and its associated error is provided in the inset box. 

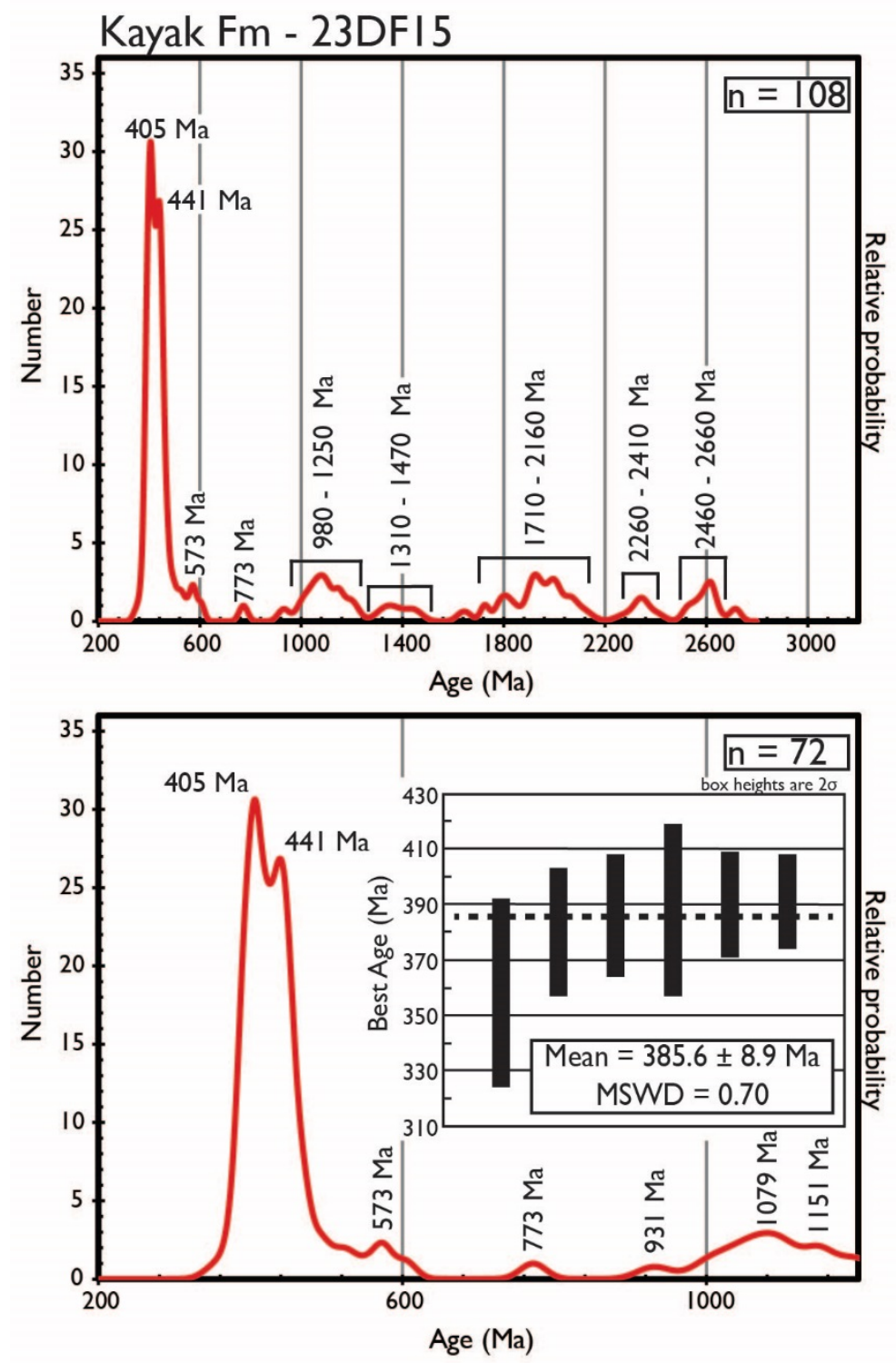

Figure 19: Probability density plot and max depositional age estimation generated from detrital zircon geochronology for sample 23DF15 - Kayak formation. See Figure 9 - marked as 23 - for sample location on a map. The top panel shows the entire range of the probability density plot. The lower panel shows a probability density plot generated from only the youngest grains younger than $1200 \mathrm{Ma}$. Dominate age groupings are labeled. Box heights in the max depositional age figure represent the $2 \sigma$ error on the analysis of that grain. The mean of the youngest population and its associated error is provided in the inset box. 

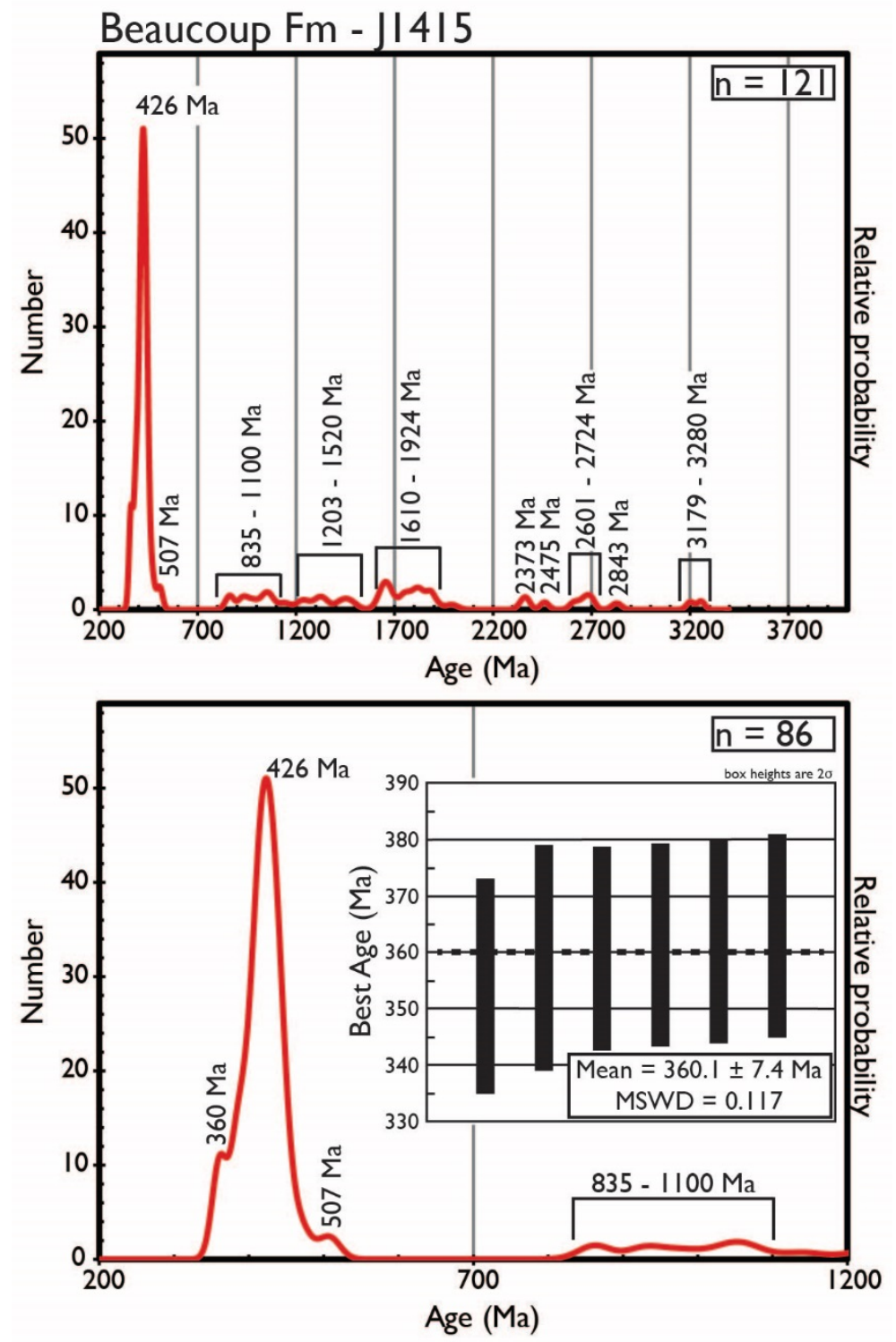

Figure 20: Probability density plot and max depositional age estimation generated from detrital zircon geochronology for sample J1415 - Beaucoup formation. See Figure 9 for sample location on a map. The top panel shows the entire range of the probability density plot. The lower panel shows a probability density plot generated from only the youngest grains - younger than 1200 Ma. Dominate age groupings are labeled. Box heights in the max depositional age figure represent the $2 \sigma$ error on the analysis of that grain. The mean of the youngest population and its associated error is provided in the inset box. 

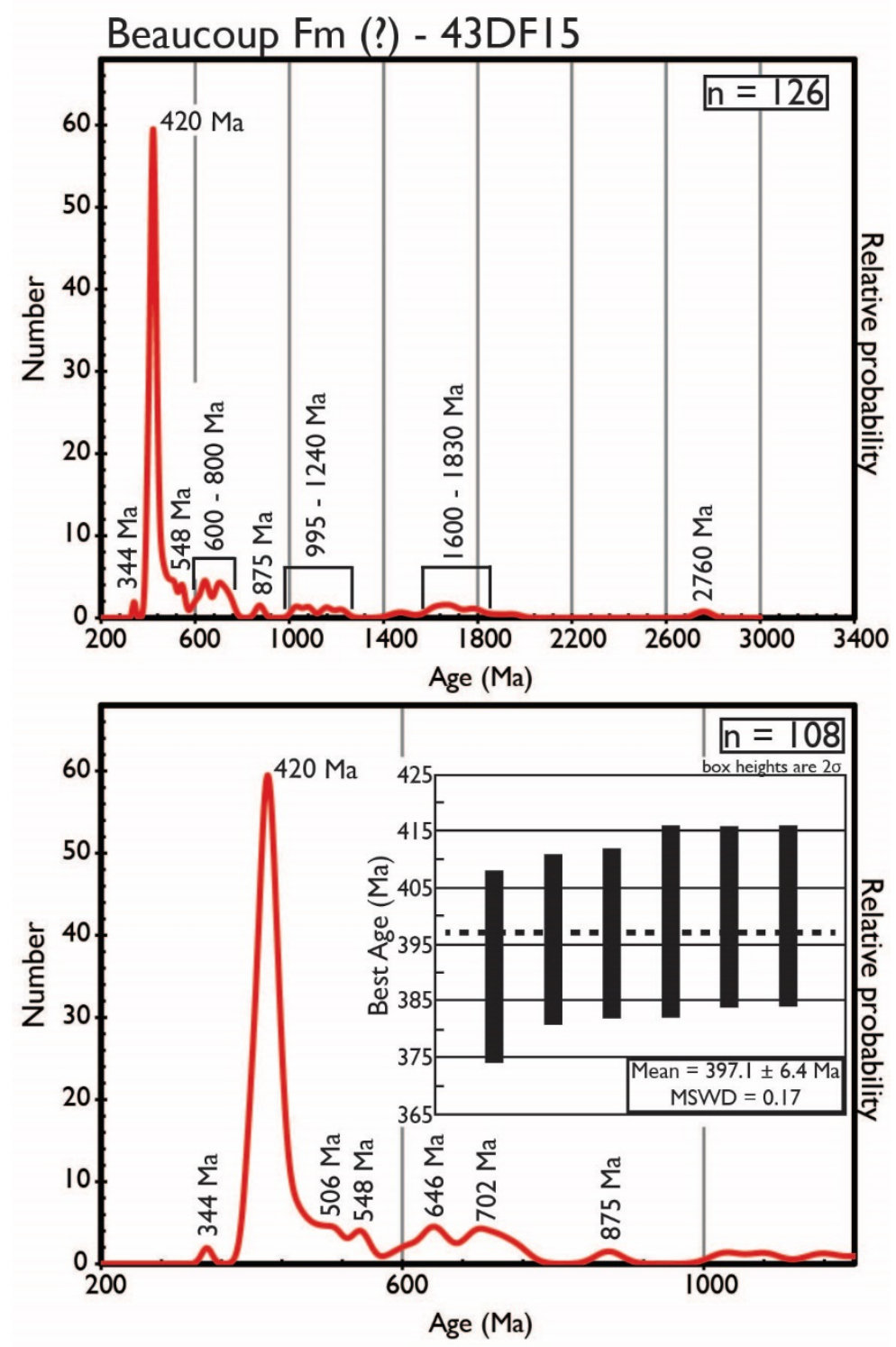

Figure 21: Probability density plot and max depositional age estimation generated from detrital zircon geochronology for sample 43DF15 - Beaucoup formation. See Figure 9 - marked as 43 for sample location on a map. The top panel shows the entire range of the probability density plot. The lower panel shows a probability density plot generated from only the youngest grains younger than $1200 \mathrm{Ma}$. Dominate age groupings are labeled. Box heights in the max depositional age figure represent the $2 \sigma$ error on the analysis of that grain. The mean of the youngest population and its associated error is provided in the inset box. 

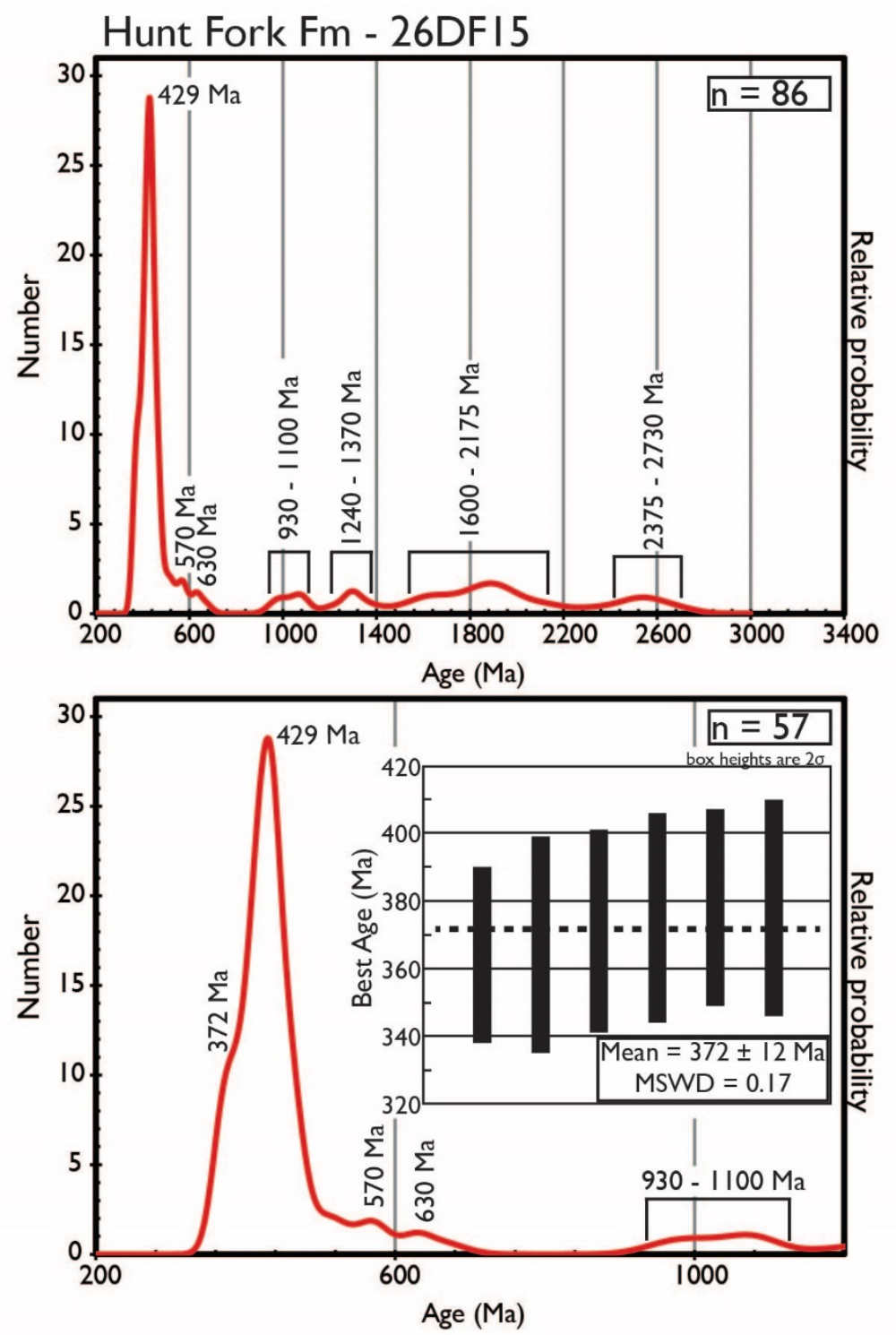

Figure 22: Probability density plot and max depositional age estimation generated from detrital zircon geochronology for sample 26DF15 - Hunt Fork (?) formation. See Figure 9 for sample location on a map. The top panel shows the entire range of the probability density plot. The lower panel shows a probability density plot generated from only the youngest grains - younger than $1200 \mathrm{Ma}$. Dominate age groupings are labeled. Box heights in the max depositional age figure represent the $2 \sigma$ error on the analysis of that grain. The mean of the youngest population and its associated error is provided in the inset box. 

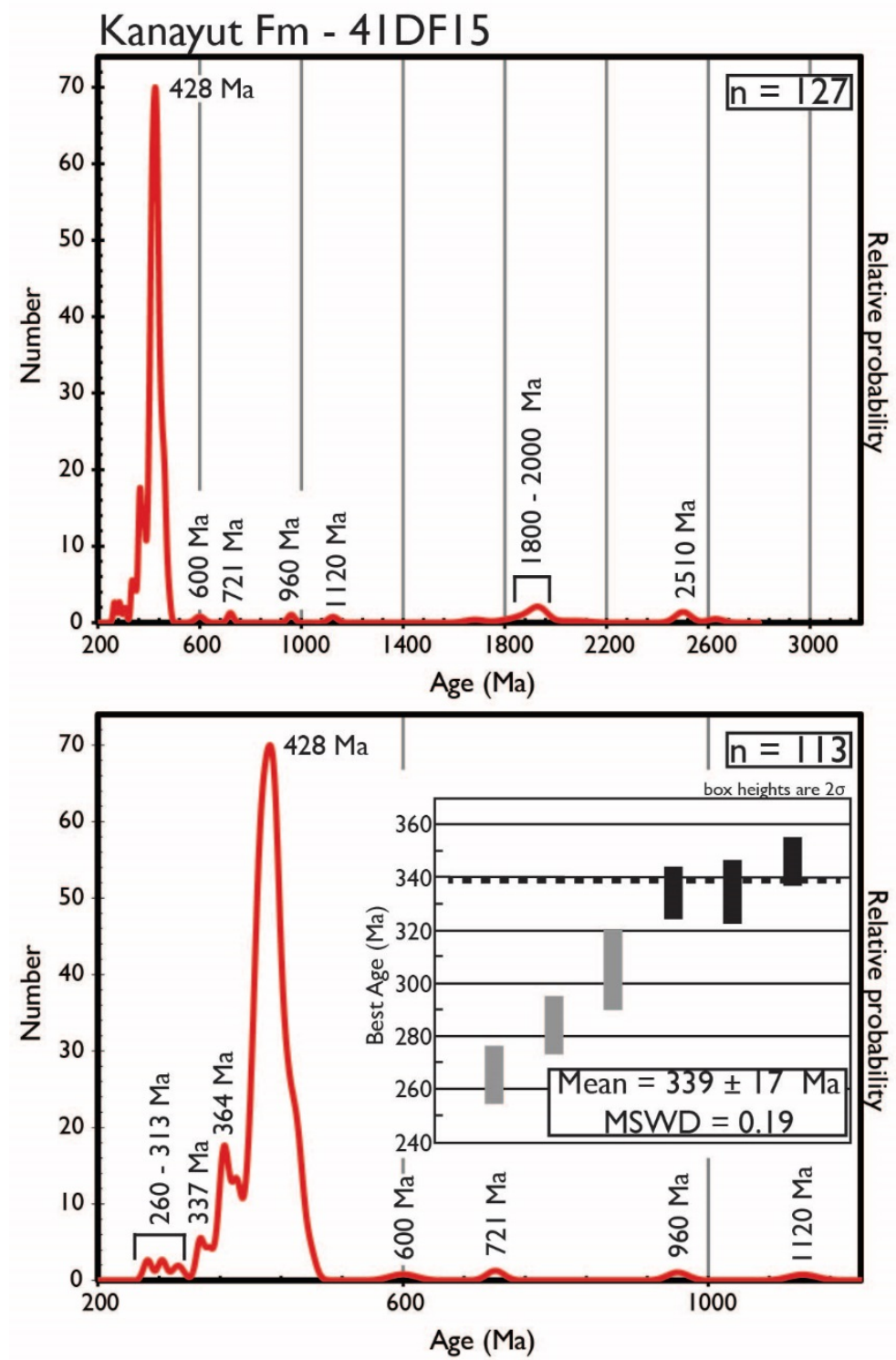

Figure 23: Probability density plot and max depositional age estimation generated from detrital zircon geochronology for sample 41DF15 - Kanayut formation. See Figure 9 for sample location on a map. The top panel shows the entire range of the probability density plot. The lower panel shows a probability density plot generated from only the youngest grains - younger than 1200 Ma. Dominate age groupings are labeled. Box heights in the max depositional age figure represent the $2 \sigma$ error on the analysis of that grain. The mean of the youngest population and its associated error is provided in the inset box. 


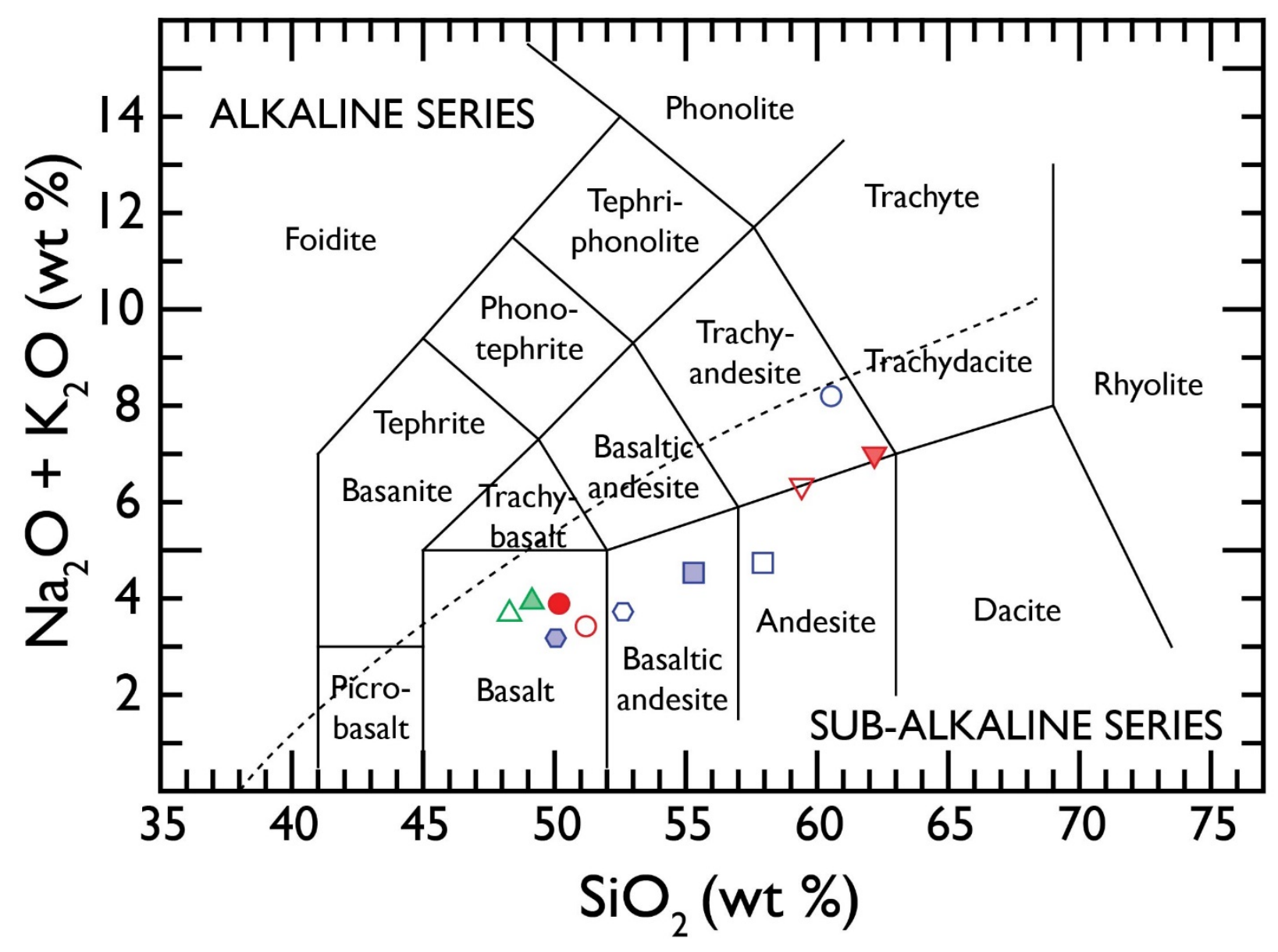

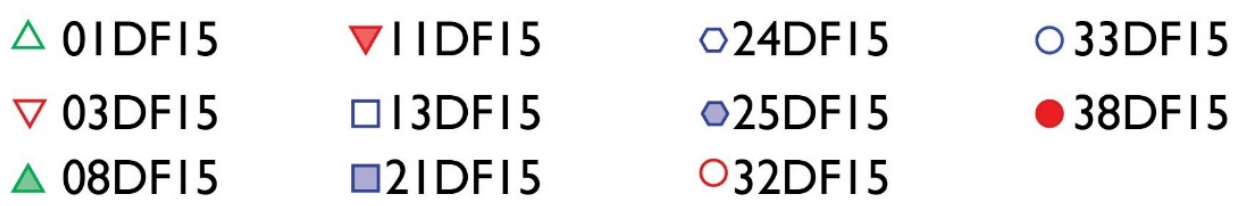

Figure 24: Total alkali $\left(\mathrm{Na}_{2} \mathrm{O}+\mathrm{K}_{2} \mathrm{O}\right.$ in wt \%) - silica $\left(\mathrm{SiO}_{2}\right.$ in wt \%) diagram with fields after Le Maitre et al. (2002). Symbols used in this plot are used in all subsequent figures. Note that the Apoon rocks from this study all plot as subalkaline rocks and can be categorized as basalts, basaltic-andesites, andesites, and trachy-andesites. All samples are normalized to $100 \%$ anhydrous; raw geochemical data are presented in Supplemental Materials section. 


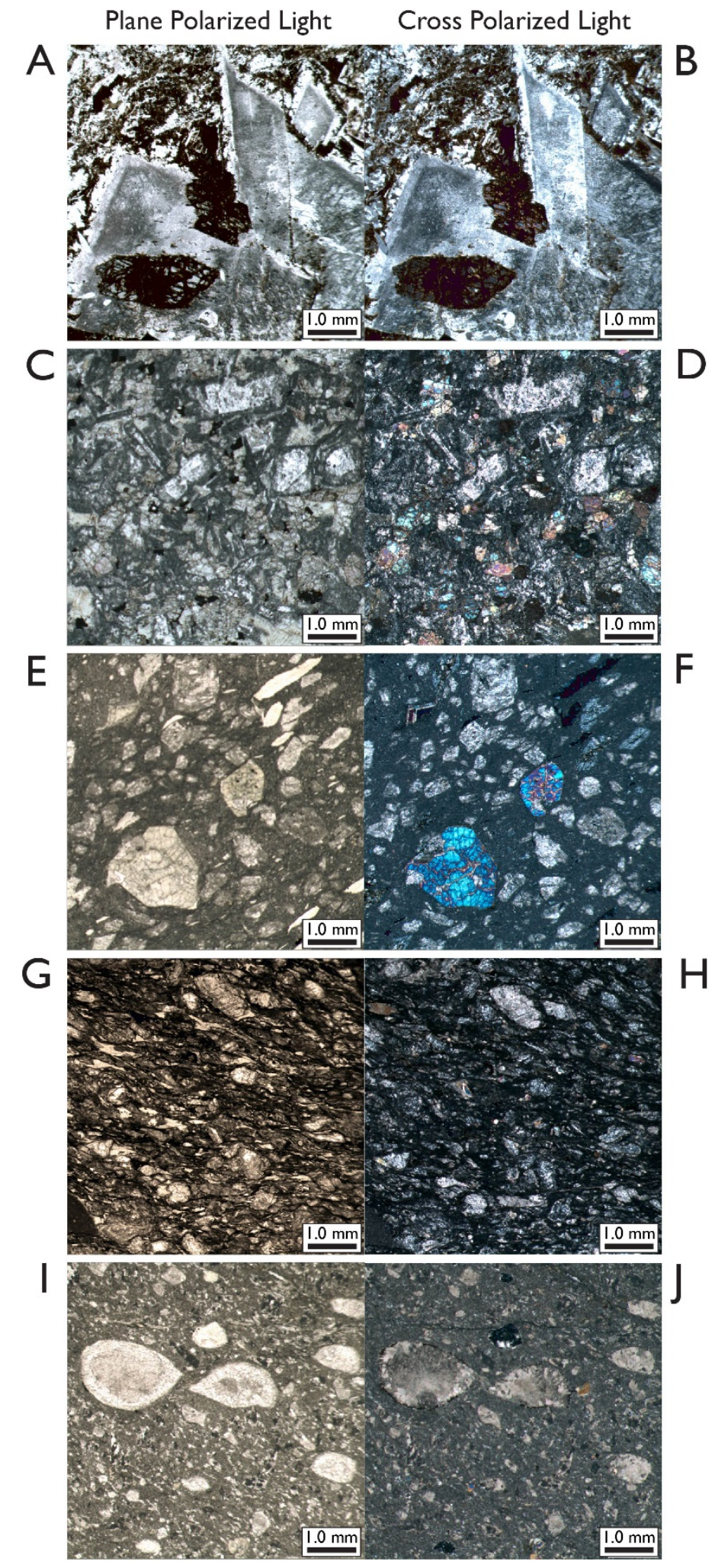

Figure 25: Representative thin section photomicrographs from igneous rocks within the Apoon assemblage demonstrating the textural and compositional variety of the Apoon assemblage's igneous portions. 


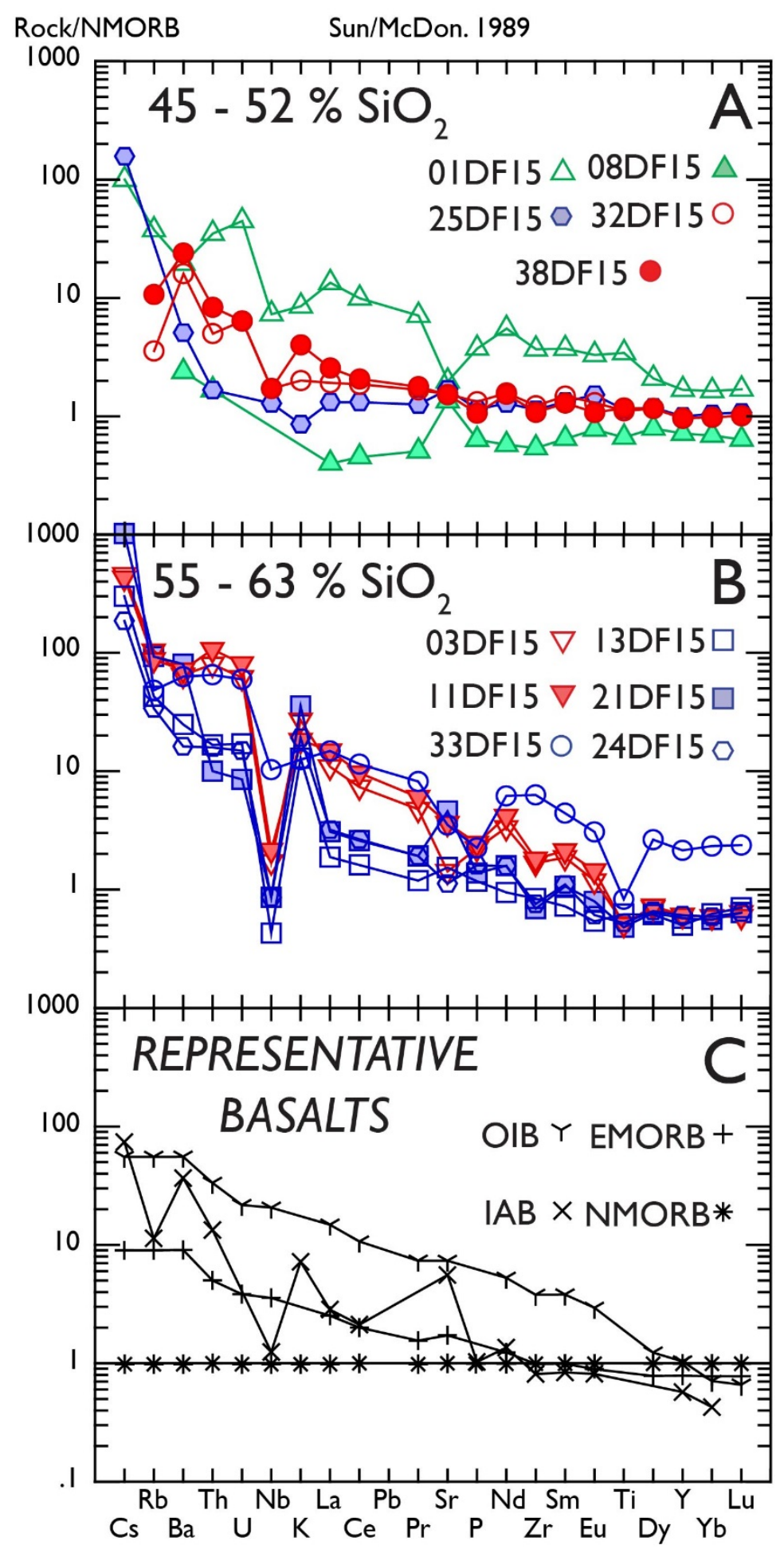

Figure 26: Trace element variation diagrams for eleven samples from the Apoon assemblage. All samples are normalized to the composition of a normal mid-ocean ridge basalt (NMORB) based on Sun and McDonnough (1989). The bottom frame plots representative basalt types from particular tectonic settings from Sun and McDonnough (1989) and Nye and Reid (1986). EMORB - Enriched Mid-Ocean Ridge Basalt; IAB - Island Arc Basalts; NMORB - Normal MidOcean Ridge Basalt; OIB - Ocean Island Basalts. 


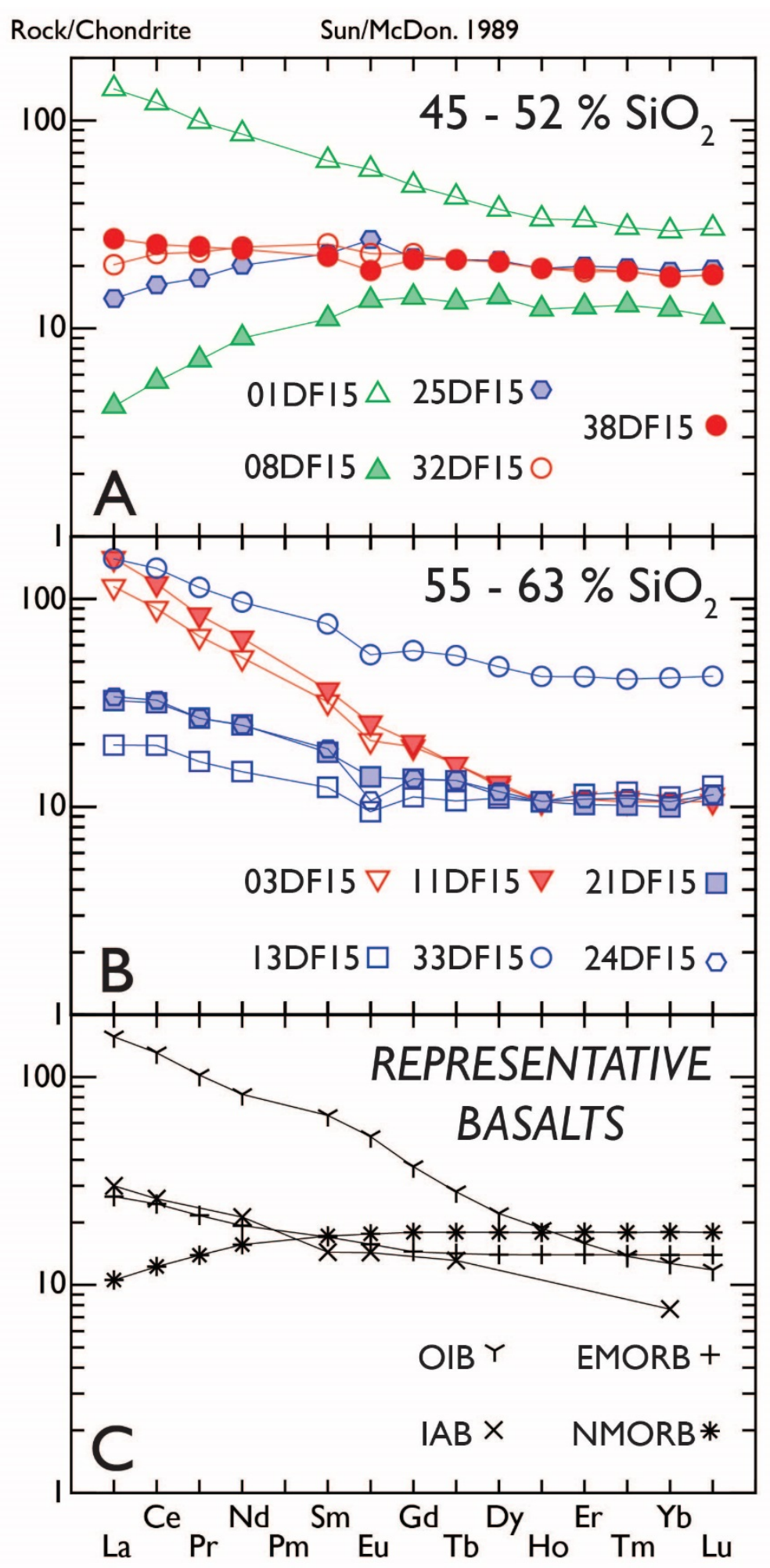

Figure 27: Chondrite-normalized trace element variation diagrams of the Apoon assemblage volcanic rocks (after Sun and McDonnough, 1989). The bottom frame plots representative basalt types from particular tectonic settings from Sun and McDonnough (1989) and Nye and Reid (1986). EMORB - Enriched Mid-Ocean Ridge Basalt; IAB - Island Arc Basalts; NMORB Normal Mid-Ocean Ridge Basalt; OIB - Ocean Island Basalts. 


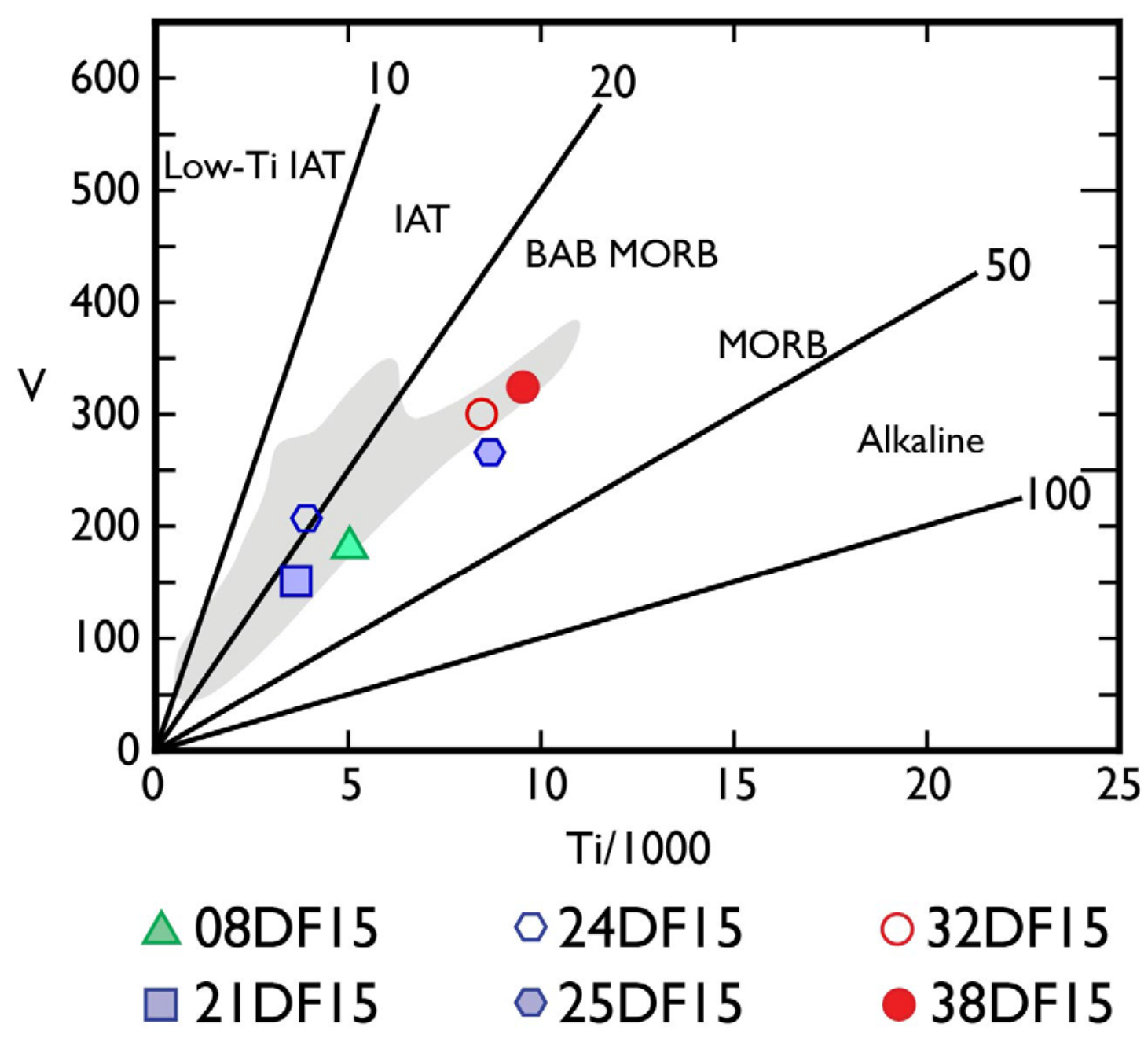

Figure 28: Ti - V tectonic discrimination diagram after Shervais (1982). The gray field marks the compositional range of samples from the Apoon assemblage from previous studies (Julian 1989; Julian and Oldow, 1998). The proportion of Ti:V is here used as a proxy for the oxygen activity within a magma during eruption and related to potential tectonic environments. BAB MORB - Back Arc Basin Mid-Ocean Ridge Basalt; IAT - Island Arc Tholeiitic; MORB - MidOcean Ridge Basalt. Only those samples that classified as basalts and basaltic-andesite (i.e. <57 wt $\% \mathrm{SiO}_{2}$ ) were included in this plot (Shervais, 1982). 


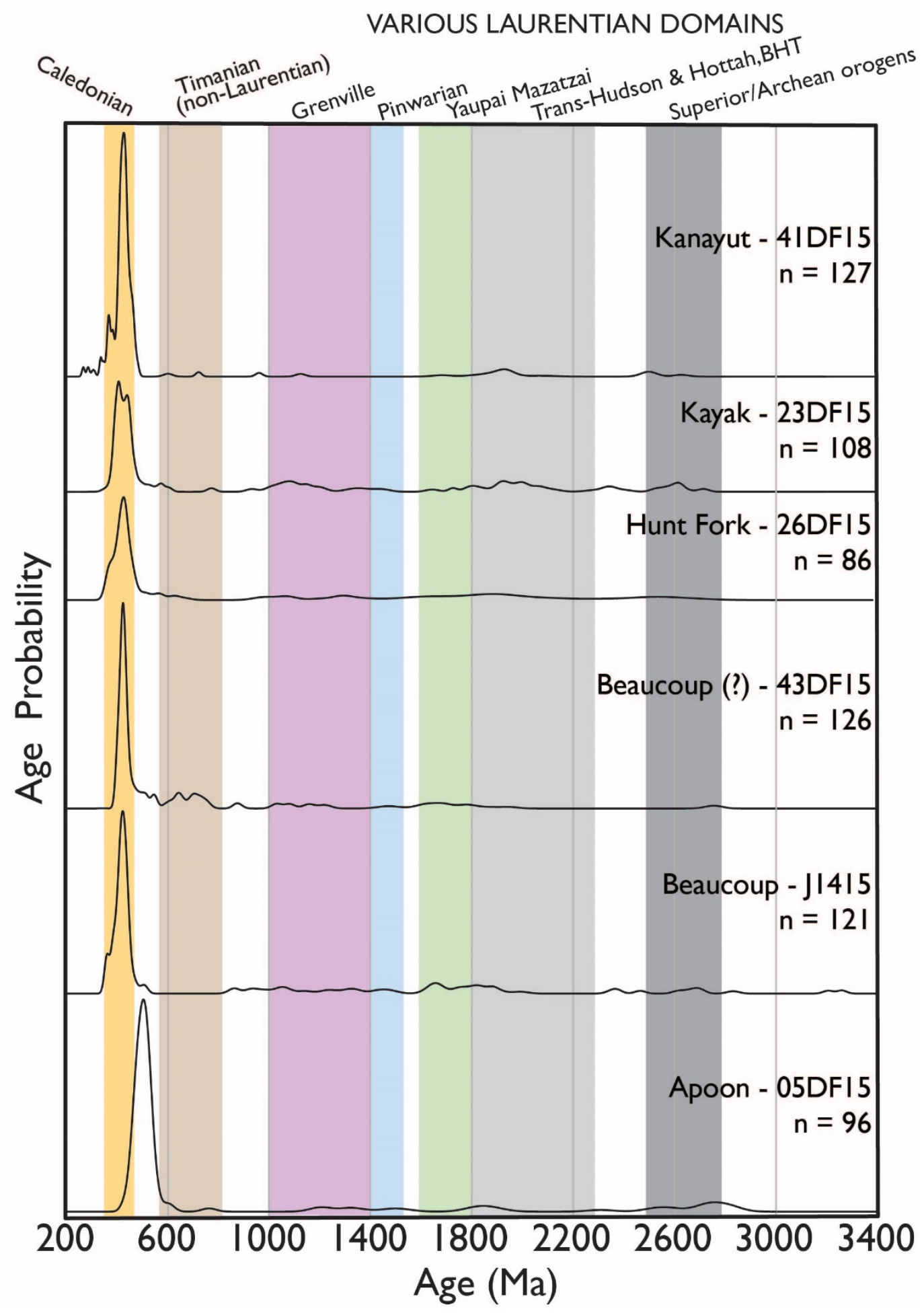

Figure 29: Stacked probability density plots from all samples within this study. Sample names and the number of grains in each analysis are given at the right side of the figure. The vertical colored bars represent the age of various orogenic episodes with affected rocks of the circumArctic. 


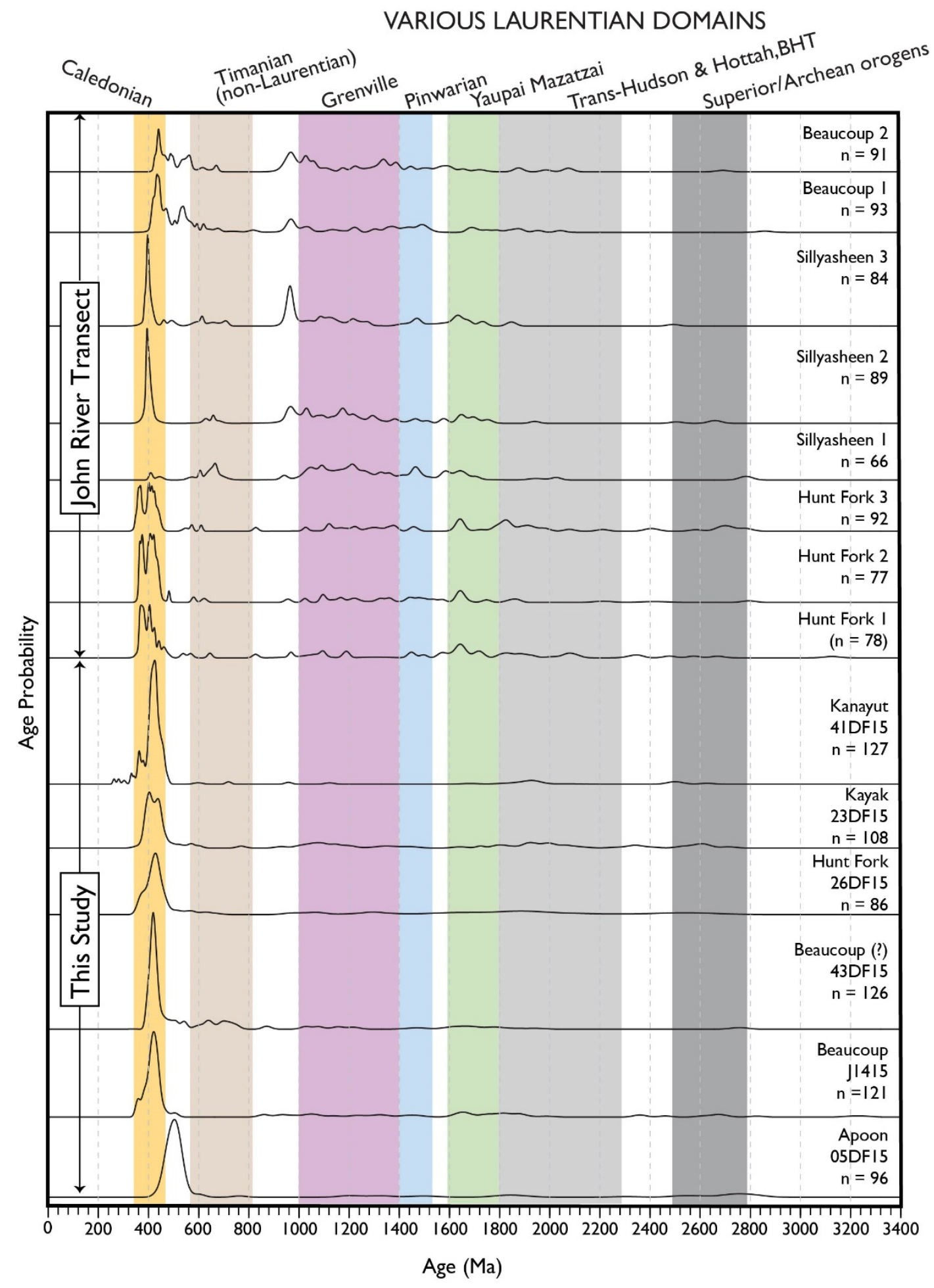

Figure 30: Stacked probability density plots from all samples within this study (lower portion of figure) and those from the John River transect of the central Brooks Range (west of Doonerak) by Miller, Pease, and Hoiland (unpublished data; upper portion of figure). Sample names and the number of grains in each analysis are given at the right side of the figure. The vertical colored bars represent the age of various orogenic episodes which may have contributed detritus to rocks of the circum-Arctic. 


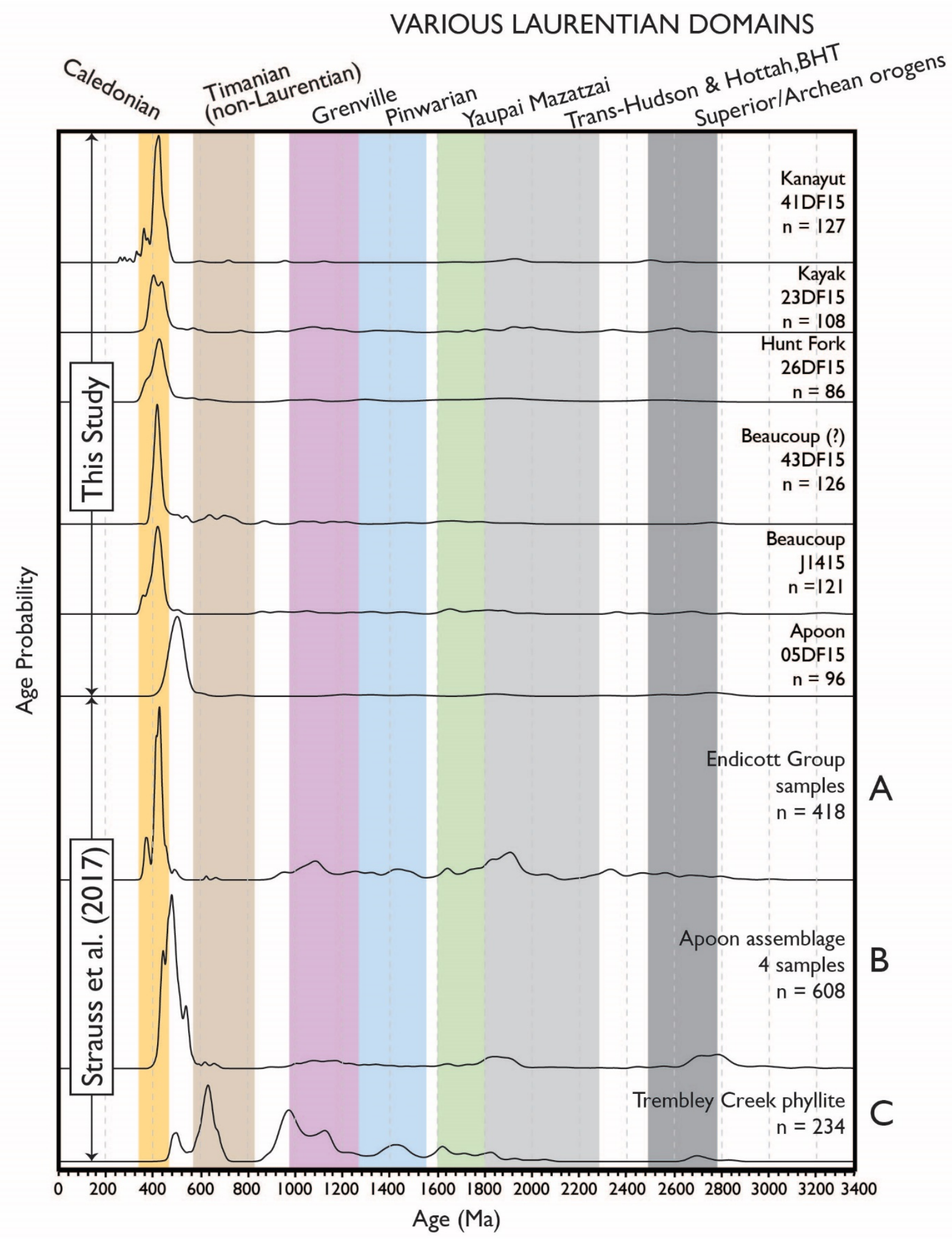

Figure 31: Stacked probability density plots from all samples within this study and those from Strauss et al. (2017). The curves from Strauss et al. (2017) provide the accumulated probability density plots from multiple samples from the same formations 


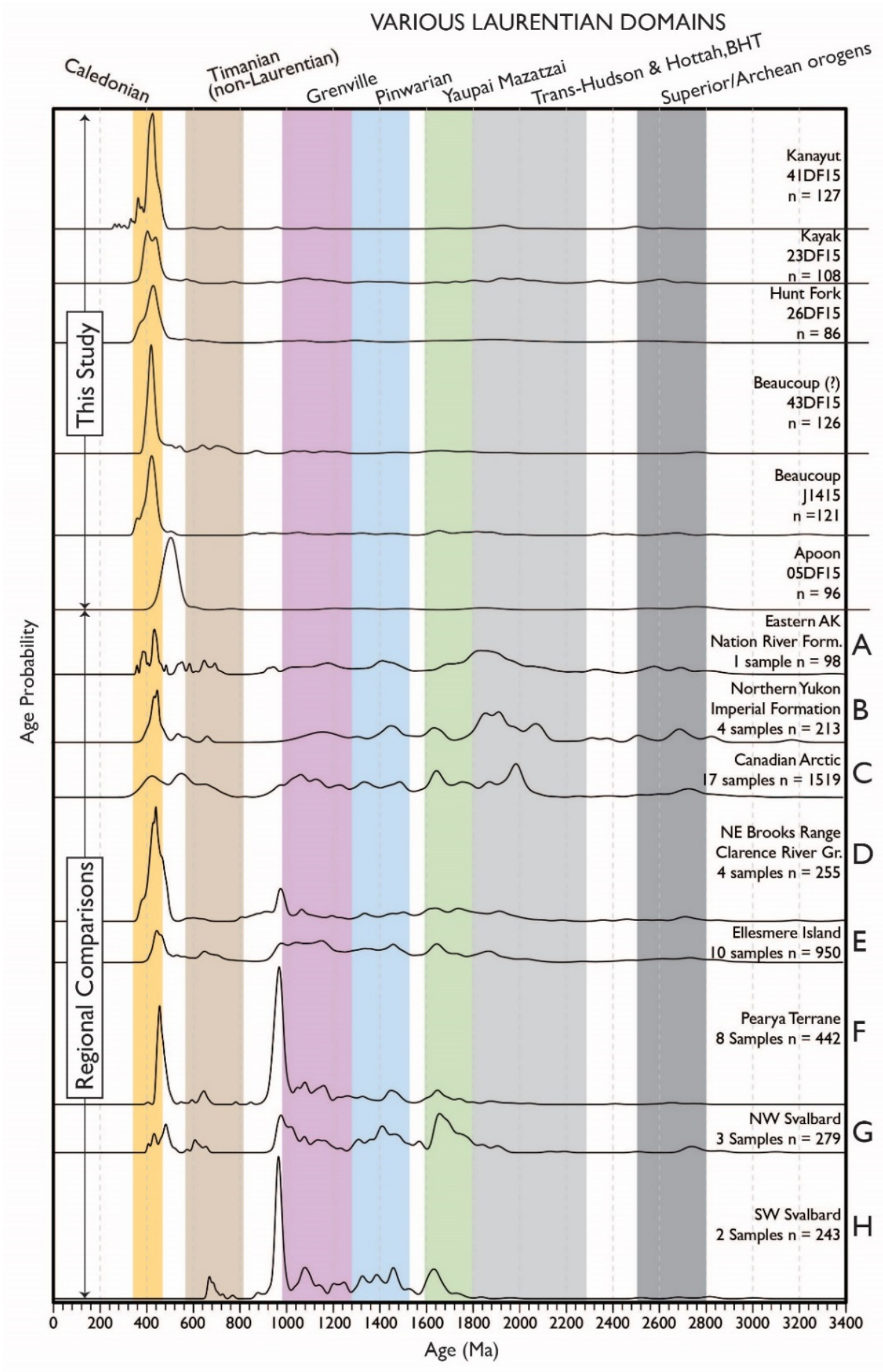

Figure 32: Stacked probability density plots from all samples within this study alongside those from a suite of regional published sources: (A) Ellesmerian clastic wedge of east-central Alaska (Gehrels and Pecha, 2014), (B) Ellesmerian clastic wedge in the Yukon (Beranek et al., 2010),

(C) Ellesmerian clastic wedge in the Canadian Arctic Islands (Anfinson et al., 2012), (D)

Clarence River Group of the northeast Brooks Range (Johnson et al., 2016), (E) Ellesmerian

Island (Beranek et al., 2015), (F) Pearya terrane (Hadlari et al., 2014); (G) northwestern Svalbard (Petterson et al., 2010); and (H) Southwestern Svalbard (Gasser and Andersen, 2013). 

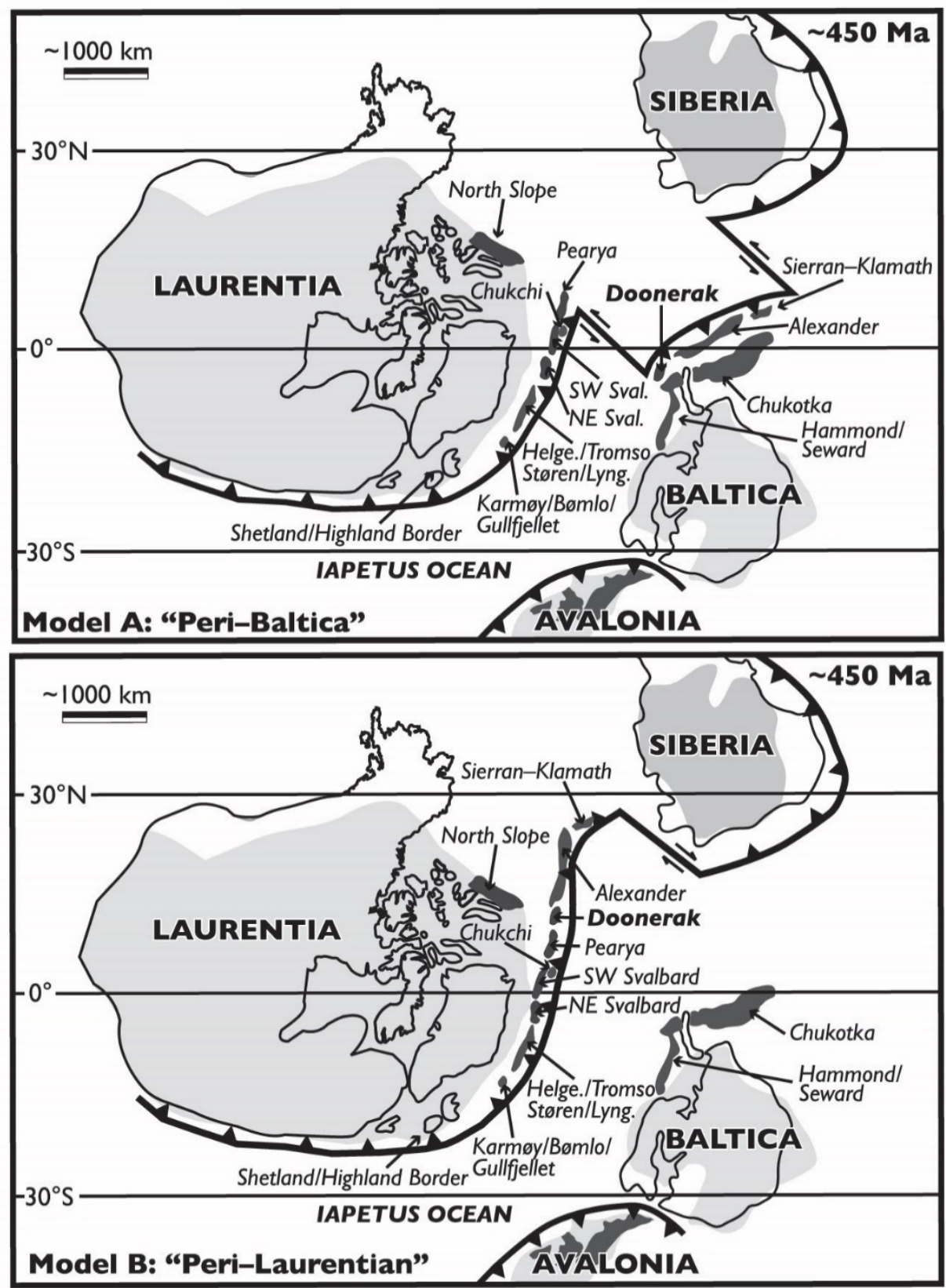

Figure 33: Schematic paleogeographic reconstructions of pertinent circum-Arctic paleocontinents, terranes, and microcontinents in the Late Ordovician from Strauss et al. (2017). Latitudinal positions are based on Cocks and Torsvik (2005, 2007, 2011, and references therein). The bulk of the North Slope of Arctic Alaska is on the peri-Laurentian margin following Strauss et al. (2013), Cox et al. (2015), and Johnson et al. (2016). (A) Paleogeographic model restoring Doonerak to a position proximal to Baltica in the Late Ordovician, in a setting similar to the Alexand er terrane and exotic portions of the Arctic Alaska-Chukotka microplate. In this model, Doonerak sits along the convergent margin of Baltica and there must be subduction polarity reversal to place Baltica on the lower plate during Scandian contraction. (B) Paleogeographic model that restores Doonerak and other circum-Arctic terranes to the northern extent of the Taconic orogenic system, proximal to Laurentia. Subduction polarity reversal is required to accrete the Pearya terrane and Doonerak onto the NE margin of Laurentia. 


\section{INTRODUCTION}

Regional tectonic and paleogeographic models of the circum-Arctic (Fig. 1) are some of the least well constrained in the world due to the regions remoteness and complex geologic relationships (e.g. Pease et al., 2011). Many tectonostratigraphic terranes of the Arctic are remnants of oceanic and continental crust from the margins of the Paleozoic Iapetus Ocean and have Siberian, Baltic, Laurentian, Gondwanan, and/or Panthalassan affinities (e.g. Trettin, 1987; Amato et al., 2009; Colpron and Nelson, 2009, 2011; Grove et al., 2008; Miller et al., 2011; Beranek et al., 2013a\&b). The Phanerozoic accretionary history of Laurentia (proto-North America) potentially involves the translation of exotic terranes (e.g. Arctic Alaska, Farewell, Alexander, Klamath-Sierra, and Pearya) across the continent's northern margin from the Caledonian-Appalachian orogen to the North American Cordillera (e.g. Colpron and Nelson, 2011; Cocks and Torsvik, 2011; Miller et al., 2011; and many others). These regional relationships make the Arctic a critical location for understanding the growth and evolution of continental margins by accretionary and, potentially, large-scale strike slip tectonics.

The Arctic Alaska terrane, one such tectonostratigraphic package, includes the Brooks Range, North Slope and Seward Peninsula of northern Alaska (Fig. 1 and 2). The northeast Brooks Range and most of the North Slope portions of the Arctic Alaska terrane share characteristics (stratigraphy, fossil assemblages, detrital zircon populations) with Laurentia (Fig. 3; Johnson et al., 2016; Strauss et al., 2013; Cox et al., 2015; McClelland et al., 2015; Lane et al., 2015), while the southwestern portion of the terrane, including the Hammond subterrane, Coldfoot subterrane, and Seward Peninsula, has dominantly Baltic and Siberian affinities (Fig. 3;

Kos’ko et al., 1993; Patrick and McClelland, 1995; Natal'in et al., 1999; Blodgett et al., 2002; Dumoulin et al., 2002; 2014; Amato et al., 2009, 2014; Miller et al., 2006, 2010, 2011; Till et al., 
2014a, 2014b; Akinin et al., 2015). These relationships suggest that a suture must exist between these different areas within Arctic Alaska, which records the amalgamation and formation of the Arctic Alaska terrane itself. Although recent efforts have attempted to better define these relationships (e.g. Strauss et al., 2017), our understanding of the timing and location of this suturing event within Arctic Alaska remains poorly constrained. The goal of this project is to constrain the nature of this boundary within Arctic Alaska through analysis of the Doonerak fenster, a strategic location which exposes structural basement of the Brooks Range between these regions of Laurentian and non-Laurentian origin.

For instance, most Arctic plate tectonic models restore the northern portion of the Arctic Alaska terrane near Point Barrow, AK to a conjugate margin near Prince Patrick Island in the Canadian Arctic by Mesozoic time (Fig. 1 and 2; e.g. Grantz et al., 2011; Lawver and Scotese, 1990; Houseknecht and Connors, 2016). This may have been achieved by way of $\sim 60^{\circ}$ rotation of Arctic Alaska around a Euler pole in the Mackenzie Delta during the Early Cretaceous (e.g. Gottlieb et al., 2014); however, one of several unresolved questions related to refining tectonic models of the Arctic concerns the position of the North Slope of Arctic Alaska from the Middle Ordovician to Late Devonian at the time of the Caledonian-Appalachian orogen (ca. 470-350 Ma; e.g. Gee, 1975; Roberts, 2003; McKerrow et al., 2000). Recent detrital geochronology of pre-Mississippian units from the Whale Mountain area in the northeast Brooks Range (Fig. 1) records a major shift in provenance and sediment dispersal that coincides temporally with the Caledonian orogeny and could be related to closure of the northern Iapetus Ocean (Johnson et al., 2016, 2013). The continuity of these relationships in the central Brooks Range is unknown. The Doonerak fenster provides a window into the pre-Mississippian basement of the central Brooks Range, exposes rocks somewhat similar to those found in the Whale Mountain 
area, and has long been enigmatic within the central Brooks Range (e.g. Dutro et al., 1976) because it provides unique exposure of mafic-to-intermediate volcanic rocks of largely unknown origin. Recent igneous and detrital geochronology and Lu-Hf isotopic data from zircon in the Doonerak fenster suggest that the Doonerak area could contain a magmatic arc complex, potentially related to the boundary between rocks of Laurentian and non-Laurentian affinity in Arctic Alaska (Strauss et al., 2017). In this context, the Doonerak fenster is critically important for understanding magmatism along the northern margin of Laurentia and closure of the Iapetus Ocean. Resolving the full tectonic context of the rocks within the Doonerak fenster could have broad implications on Neoproterozoic - Paleozoic plate reconstructions of the circum-Arctic (e.g. Dutro et al., 1973; Moore et al., 1994; Strauss et al., 2013). Herein, I present new detrital geochronologic data from the Doonerak area (from the fenster itself and the overlying allochthonous package) and whole-rock geochemistry from Doonerak’s suite of igneous rocks. The objective this work is to provide evidence to help resolve the tectonic setting of the Doonerak fenster and related areas of the Arctic Alaska terrane during Caledonian-Appalachian orogenesis and to further define the position and nature of the boundary between Laurentian and non-Laurentian rocks in Arctic Alaska.

\section{THE ARCTIC LITHOSPHERE}

\subsection{The Arctic Oceanic Realm}

The Arctic Ocean includes two distinct oceanic basins, the Eurasia and Amerasia Basins (Fig. 1), and is surrounded by continental landmasses that share many characteristics, such as floral and faunal assemblages, detrital zircon populations, and deformation histories (e.g. Pease 
et al., 2014, 2011; Miller et al., 2010). However, the tectonic evolution that led to these relationships and to the modern configuration of these landmasses is poorly understood. The younger of these ocean basins, the Eurasia basin, formed by seafloor spreading along the northern portion of the modern Atlantic/Arctic spreading center, the Gakkel Ridge, during Cenozoic time. This spreading center marks the modern boundary between the North American and Eurasian lithospheric plates in the Arctic (Engen et al., 2003; Karasik, 1968; Kristoffersen, 1990; Savostin and Karasik, 1981; Vogt et al., 1979).

The Eurasia basin contains well-mapped magnetic anomalies, which indicate that spreading began in the Cenozoic (c. $58 \mathrm{Ma}$ - magnetic chron A25) between the Lomonosov Ridge and the Barents-Kara continental margin (Brozena et al., 2003; Glebovsky et al., 2006; Grants et al., 2011; Karasik, 1968, 1974; Kristoffersen, 1990; Vogt et al., 1979). Rates of seafloor spreading along the Gakkel Ridge are among the slowest in the world (Cook et al., 1986; Glebovsky et al., 2006; Karasic, 1974; Vogt et al., 1979). Very slow spreading may have contributed to the great variability in topography of the basin as a product of interplay between variable magmatism and crustal production with extension of the crust itself (Louden et al., 1996; Mutter and Karson, 1992; Small and Sandwell, 1992).

The Lomonosov Ridge (Fig. 1) is a poorly understood fragment of Eurasian continental crust that extends from northern Greenland toward the Siberian continental shelf, bisecting the Arctic Ocean (Brozena et al., 2003; Glebovsky et al., 2006; Grantz et al., 2001; Jokat et al., 1992; Karasik, 1968, 1974; Kristoffersen, 1990; Vogt et al., 1979). The Amerasia Basin lies to the west of the Lomonosov Ridge (Fig. 1) and is surrounded by the Canadian Arctic Islands, northern Alaska, and the Chukotka peninsula of northern Russia. It is larger than the Eurasia Basin and highly heterogeneous. The pre-Amerasia Basin configuration of the Arctic's 
landmasses and the processes by which the basin opened are both unclear. The Amerasia Basin consists of several different physiographic regions, including the Canada Basin.

The Canada Basin is the most pertinent portion of the Amerasia Basin in terms of this study. It is bordered to the north by the Alpha-Mendeleev ridge province, to the west by the Chukchi Borderland, to the southeast by the Canadian Arctic Islands (Ellesmerian Fold Belt), and to the southwest by the continental margin of Arctic Alaska (Fig. 1). The Canada Basin is enigmatic; there is no consensus as to the nature of its crust or the mechanisms by which it opened (e.g. Lawver and Scotese, 1990). Saltus et al. (2011) used magnetic data to conclude that the basin is underlain by crust that is not typical of oceanic lithosphere; however, gravity data (Laxon and McAdoo, 1994, 1998) and regional seismic lines (Dinkelman et al., 2008; Helwig et al., 2011) suggest the existence of an extinct spreading center. Despite a lack of direct dating of basement material, most models for the opening of the Canada Basin assume that sea-floor spreading occurred during the Cretaceous on the basis of stratigraphic similarities along the basin’s margins (e.g. Lawver and Scotese, 1990; Grantz et al., 2011a; Mosher et al., 2012; Spencer et al., 2011; Lane, 1997).

\subsection{The Arctic Continental Realm}

One method to understand the evolution of the Arctic Ocean is to better define the linkages between the different tectonostratigraphic terranes of its surrounding landmasses. Many of the Arctic's landmasses include tectonostratigraphic terranes derived from oceanic and continental crust from the margins of the Iapetus Ocean. These include terranes of Siberian, Baltic, Laurentian, Gondwanan and Panthalassan affinities (e.g. Trettin, 1987; Amato et al., 
2009; Colpron and Nelson, 2009, 2011; Grove et al., 2008; Miller et al., 2011; Beranek et al., 2013). The Arctic Alaska - Chukotka Microcontinent (AACM) is one such tectonostratigraphic package. The AACM includes the Brooks Range, North Slope, and Seward Peninsula of Alaska, the Chukotka Peninsula, Wrangel Island, and New Siberian Islands of Russia, and the continental shelves surrounding the Bering, Beaufort, and Chukchi seas (Fig. 1 \& 2; e.g. Miller et al., 2006). The southern terminus of the AACM is marked by the Angayucham suture in Alaska (e.g. Moore et al., 1994) and the South Anyui suture zone in Russia (e.g. Seslavinskiy, 1979; Sokolov et al., 2002), where belts of ophiolites record oceanic closure that occurred as terranes of southern Alaska and Siberia collided with the AACM (Moore et al., 1994; Pease et al., 2014; Nokleberg et al., 2000; Zonenshain and Napatov, 1989). The geology of the AACM preserves evidence of a long-lived multiphase accretionary history. Because of its location at the edge of the Canada Basin, the AACM also provides critical piercing points for developing Mesozoic reconstructions of the Arctic and opening of the Arctic Ocean (e.g. Miller et al., 2006). The AACM has important paleogeographic links with various circum-Arctic paleocontinents (Dumoulin et al., 2002, 2014; Blodgett et al., 2002; Amato et al., 2009, 2014; Macdonald et al., 2009; Cocks and Torsvik, 2011; Strauss et al., 2013; Cox et al., 2015); however, much of the older history has been overprinted by the relatively young Jurassic-Cretaceous orogenesis which formed the Brooks Range (Brookian orogeny) in Alaska (Moore et al., 1994 and references therein) and the Verkhoyansk-Kolyma and Chukotka orogenic belts in Russia (Fig. 2; e.g. Oxman, 2003 and references therein). These orogenic belts incorporated crust which had previously been affected by older circum-Arctic orogenic episodes (Fig. 2; section 3.4).

The Arctic Alaska terrane, the Alaskan portion of the AACM (Fig. 3), is internally complex, which complicates attempts to restore its paleogeography. The northeast Brooks Range 
and North Slope portions of the Arctic Alaska terrane have stratigraphy, fossil assemblages, and detrital zircon populations that indicate a Laurentian (North American) origin (Johnson et al., 2016; Strauss et al., 2013; Cox et al., 2015; McClelland et al., 2015; Lane et al., 2015).

Conversely, the Hammond and Coldfoot subterranes, to the southwest, have dominantly Baltic and Siberian affinities (Fig. 3; Kos'ko et al., 1993; Patrick and McClelland, 1996; Natal'in et al., 1999; Blodgett et al., 2002; Dumoulin et al., 2002; 2014; Amato et al., 2009, 2014; Miller et al., 2006, 2010, 2011; Till et al., 2014a, 2014b; Akinin et al., 2015). This implies that there must be a boundary between these different areas within Arctic Alaska. A presumably Paleozoic suture, which records the amalgamation and formation of the Arctic Alaska terrane, must lie between these crustal blocks separating Laurentian and non-Laurentian portions of the Arctic Alaska terrane. We do not know the precise timing or mechanism by which Arctic Alaska amalgamated; however, Ordovician-Silurian potentially arc-related rocks of the Doonerak fenster in the central Brooks Range could be related to that internal suture within Arctic Alaska (Mull, 1982; Moore et al., 1997; Grantz et al., 1991; Dumoulin et al., 2000; Strauss et al., 2013, 2017). As such, Doonerak is an important locale for understanding amalgamation of the Arctic Alaska terrane, Paleozoic magmatism, and the closure of the northern Iapetus Ocean.

\subsection{Relationships between Arctic landmasses}

Several models for the opening of the Canada Basin attempt to reconstruct the relationships between the Arctic's landmasses by placing portions of the North Slope in a position against the Canadian Arctic Margin in pre-Mesozoic time (e.g. Lawver and Scotese,

1990; Lawver et al., 2002; Miller et al., 2006; Colpron and Nelson, 2009; Macdonald et al., 
2009). These models all agree that parts of the Arctic Alaska terrane and Canadian Arctic Islands were previously contiguous because they share similar paleontological, detrital zircon, and stratigraphic relationships, but the models differ in the precise mechanisms by which Arctic Alaska achieved its modern position. Determining the precise pre-Canada Basin positions and relationships of these landmasses has direct bearing on developing viable paleogeographic reconstructions and models for basin opening. Defining the mechanisms by which Laurentian and non-Laurentian portions of Arctic Alaska amalgamated and simply defining the location of that boundary with more precision are needed to inform these models. This study provides new geochemical and geochronological data from border between Laurentian and non-Laurentian regions of Arctic Alaska in order to constrain these relationships.

One widely accepted model for the opening of the Canada Basin involves the clockwise rotation $\left(\sim 60-70^{\circ}\right)$ of the AACM, including Arctic Alaska terrane, away from the Canadian Arctic Islands about a pole of rotation located in the Mackenzie Delta (e.g. Grantz et al., 2011; Lawver et al., 2002). This assumes that exotic terranes of Chukotka, Alaska, and the Canadian Arctic arrived against the Laurentian margin as the northern Iapetus Ocean closed, before any Mesozoic rifting (e.g. Lawver et al., 2002). The simple rotational model predicts opening of the Canada Basin as a consequence of this rotation, between the Canadian Arctic and Arctic Alaska; however, it fails to explain the overlap of the Siberian continental shelf and Canadian Arctic Islands ( $\sim 60 \mathrm{~km}$ of overlap) implied by this restoration (Lane, 1997).

Miller et al. (2006) used a more complex combination of rifting and strike-slip displacement to rectify the overlap generated in the simple rotation model. This model allows portions of Arctic Alaska and Chukotka to behave as non-coherent, independent masses with different tectonic and depositional histories. Miller et al., (2006) use detrital zircon data from 
Triassic sandstones of Siberia, Chukotka, northern Alaska, and northern Canada to suggest that Chukotka and the East Siberian Shelf were in a different pre-rift paleogeographic position than Arctic Alaska. During the Triassic, Chukotka and the East Siberian Shelf must have been in a position to receive detritus from the Siberian craton, while Arctic Alaska was receiving detritus from the northern margin of Laurentia near the Canadian margin (Miller et al., 2006).

The Paleozoic geographic position of these same landmasses is more unclear. Stratigraphic similarities between the Seward Peninsula (western AK), Chukotka Peninsula, and portions of the Brooks Range are suggestive of unified deposition in the Lower Paleozoic (Natal'in et al., 1999). Fossil evidence suggests a Siberian affinity for parts of Arctic Alaska and Chukotka in the mid-Paleozoic (Blodgett et al., 2002; Dumoulin et al., 2002) and that Arctic Alaska and Siberia shared faunal assemblages by the Early Ordovician (Dumoulin and Harris, 1994; Dumoulin et al., 2002). These data suggest that portions of Arctic Alaska may have rifted from Siberia in the Devonian or that they had Cambrian to Devonian ties to northeastern Baltica (e.g. Blodgett et al., 2002). Amato et al., (2009) used U-Pb zircon geochronology from igneous and detrital rocks, along with Nd isotopic data from basement rock of the Seward Peninsula to point to an origin exotic to western Laurentia. They also developed a pre-Canada Basin Mesozoic reconstruction in which the Brooks Range, Seward Peninsula, and North Slope are near the Canadian Arctic Islands from the Mississippian to the Jurassic.

\subsection{Relation to research goals}

In order to constrain its paleogeography, we need to better understand the internal complexity within Arctic Alaska and define the boundary between rocks of Laurentian and non- 
Laurentian origin. Defining this boundary would provide greater constraints on PaleozoicMesozoic reconstructions and allow future studies to better evaluate the mechanisms and timing of that amalgamation. This study focuses on the Doonerak fenster, a strategic location in the central Brooks Range, which is one of the best candidates for identifying the Paleozoic suture that must exist between the Laurentian and non-Laurentian portions of Arctic Alaska. Thus, the overarching goal of this research is to provide evidence for the Paleozoic tectonic setting of the rocks exposed within the Doonerak fenster and to better understand their relationship to the allochthonous rocks which overlie the fenster within the Brookian fold thrust belt. To that end, the goals of this work are 1) determine the age and provenance of the metasedimentary rocks within the Doonerak area, both interior and exterior to the fenster and 2) characterize the geochemical affinities of the volcanic rocks exposed in the fenster that may be related to this presumed Paleozoic suture. The combination of these efforts will place tighter constraints on the Paleozoic suture and various paleogeographic models outlined above. We test the hypothesis that the Doonerak fenster preserves the remnant of an island arc complex and marks the location of the suture between Laurentia and Siberian portions of Arctic Alaska. The data presented herein complements recent publications focused on the northeastern Brooks Range and Doonerak fenster by Johnson et al. (2016) and Strauss et al. (2017) respectively.

\section{THE DOONERAK FENSTER - LOCATION AND GEOLOGIC SETTING}

\subsection{Terranes and Subterranes - Context within Arctic Alaska}

Broadly, northernmost Alaska contains two lithostratigraphic terranes: the Arctic Alaska terrane and Angayucham terrane (Fig. 3; Moore et al., 1994; Silberling et al., 1994). Both occupy 
portions of the Brookian orogen. The Brooks Range is the $1000 \mathrm{~km}$ long E-W trending northvergent fold-thrust belt that extends across northern Alaska and into the Yukon of Canada (e.g. Mull, 1982; Oldow et al., 1987a; Grantz et al., 1991; Moore et al., 1994).

The Angayucham terrane is the structurally highest nappe associated with the Brooks Range and contains mostly mafic and ultramafic rocks with minor pelagic rocks of Devonian to Jurassic age (Fig. 3; Roeder and Mull, 1978; Moore et al., 1994). Spatial relationships, stratigraphic associations, and geochemical trends from Angayucham's igneous rocks suggest that the terrane is an internally complex package of obducted oceanic crust which was transported northward and accreted onto the southern Arctic Alaska terrane during Jurassic to Cretaceous orogenesis (e.g. Roeder and Mull, 1978; Barker et al., 1988; Pallister and Budahn, 1989). The Arctic Alaska terrane is more extensive and underlies the Colville basin and Brooks Range (e.g. Mull, 1982; Moore et al., 1994). It can be divided into six subterranes or allochthons on the basis of stratigraphy, facies, metamorphic grade, and structural position (Fig. 3; e.g. Moore et al., 1994; Mull, 1982; Jones et al., 1987; Mayfield et al., 1988). From north to south (i.e. foreland to hinterland), these are the North Slope, Endicott Mountains, De Long Mountains, Hammond, Coldfoot, and Slate Creek subterranes. Variations in the nomenclature of the Brooks Range complicate understanding of the region in general (e.g. Karl and Mull, 1993). A belt nomenclature related to the metamorphic grade of these packages is also used to describe northern Alaska (Fig. 3). These nomenclatures are nearly equivalent, but the subterrane nomenclature will be used throughout this document.

The North Slope, the structurally lowest of Arctic Alaska’s subterranes, includes rocks of the northeastern Brooks Range, Lisburne Hills, Barrow arch, and Colville basin subsurface (Fig. 3). In the Colville basin subsurface, these rocks are not extensively deformed by post- 
Mississippian orogenesis, but in the northeastern Brooks Range the same units show considerable deformation by Cretaceous to Cenozoic contraction. The outcrop of North Slope units south of the Endicott Mountains, in the Doonerak fenster, indicates that the other subterranes within the Brooks Range are structurally emplaced above rocks that are related to the North Slope's basement (Fig. 3).

In some areas across the Brooks Range, the Endicott Mountains allochthon is structurally overlain by De Long Mountains subterrane. Both are imbricated packages of Paleozoic to Mesozoic rocks, but they differ in specific stratigraphic relations. The Hammond subterrane (Fig. 3), south of the Endicott Mountains and Doonerak fenster, includes most of the Proterozoic and lower Paleozoic sedimentary units found in the Endicott Mountains of the central Brooks Range; however, the Hammond subterrane includes ductile deformation structures and greenschist to blueschist facies mineralogy with only sporadic relict primary igneous and sedimentary textures (e.g. Moore et al., 1994). The Coldfoot and Slate Creek subterranes of the southern Brooks Range contain metamorphosed rocks of the Brookian hinterland. The Coldfoot subterrane contains blueschist and greenschist facies schist, calc-schist, marble, and metavolcanic rocks. The Slate Creek subterrane is mostly composed of phyllite and lesser metasandstone of Devonian age. The Colville basin, Koyukuk basin, and Beaufort Sea shelf flank the perimeter of the Arctic Alaska terrane and are post-tectonic basins, which have experienced only minor shortening from the Cretaceous to Cenozoic (Tailleur and Brosgé, 1970; Patton et al., 1994; Moore et al., 1994).

The various subterranes of Arctic Alaska can also be divided into two broad categories based on their paleogeographic relationships: those of Laurentian and non-Laurentian origin (Fig. 3). Several previous workers suggested a Laurentian origin for the North Slope and 
northeastern Brooks Range portions of the Arctic Alaska terrane (e.g. Dutro et al., 1972; Moore et al., 1994, 2011; Lane, 2007; Johnson et al., 2016; Strauss et al., 2013, 2017), but others argue for an exotic origin on the basis of paleobiogeographic affinities of fossil assemblages and geochronologic constraints from the southwestern portion of Arctic Alaska (Dumoulin et al., 2002; Blodgett et al., 2002; Miller et al., 2006, 2010, 2011; Amato et al., 2009). It is important to define the boundary between these paleogeographically distinct regions in order to develop models for the Paleozoic tectonic evolution of the Arctic. The pre-Mesozoic origin of Arctic Alaska's subterranes and their relationships to Laurentia are also vitally important because they have direct bearing on developing constraints on kinematic models for the Jurassic-Cretaceous opening of the Amerasia Basin (e.g. Grantz and May, 1983) and on the development of hydrocarbon resources along the Arctic's continental shelves. The development of reliable piercing points for such Mesozoic tectonic reconstructions rests on constraining the relationships between the crustal fragments of the Arctic Alaska - Chukotka microcontinent.

\subsection{Pertinent Stratigraphy}

The Endicott Group unconformably overlies the lower Paleozoic volcanic and volcaniclastic rocks in the North Slope subsurface and within the Doonerak fenster. It consists of the Upper Devonian-to-Lower Mississippian Kekiktuk Conglomerate and the Lower Mississippian Kayak Shale (Fig. 4 \& 5; Armstrong et al., 1976). The Kekiktuk Conglomerate is a terrigenous clastic succession which rests above a regional sub-Mississippian unconformity in the North Slope subsurface and northeast Brooks Range. Regionally, it ranges from many hundreds of meters thick in the North Slope subsurface (Melvin, 1993; Miller, 1991) to a 
relatively thin and discontinuous unit in the northeast Brooks Range (Le Pain et al., 1994). The position of the Kekiktuk Conglomerate above the regional unconformity, its diversity of interpreted lithofacies and paleoenvironments, widespread distribution, and relationship to overlying marginal to shallow marine shales is suggestive of deposition along a progressively subsiding passive continental margin (e.g. Le Pain et al., 1994). The regional sub-Mississippian unconformity could reflect a transition from contractional tectonics below to extension and thermally controlled passive margin subsidence above (e.g. Le Pain, 1994, Anderson and Wallace, 1991; Moore et al., 1992; Anderson, 1993); therefore, the Kekiktuk Conglomerate (broadly correlative to the Kanayut Conglomerate of the Endicott Group within the Endicott Mountains allochthon; Fig. 5) is the basal terrigenous clastic portion of a larger continental margin succession - the Ellesmerian sequence (LePain et al., 1994; Moore et al., 1992).

En masse, the Endicott Group of the northeast Brooks Range is a transgressive succession (Brosgé et al., 1962; Armstrong, 1974; Armstrong and Bird, 1974; Nilsen, 1981). This succession is marked by the transition from the fluvial to marginal marine depositional settings of the Kekiktuk Conglomerate into the marginal marine to shallow marine lithofacies of the Kayak Shale. The unconformity at the base of the Kekiktuk is significant because it potentially marks cessation of the Devonian Romanzof (or Ellesmerian) orogeny, with dominantly contractional tectonics below and extension followed by thermal subsidence above (Churkin, 1969, 1975; Brosgé et al., 1962; Reed, 1968; Dutro, 1970; Sable, 1977; Oldow et al., 1987a\&b; Moore et al., 1994; Lane, 2007; LePain, 1994). However, in the Endicott Mountains Allochthon (EMA), the sub-Mississippian unconformity is absent and Devonian age strata pass conformably up section into the Carboniferous (Fig. 5). The thick Upper Devonian to Carboniferous clastic package of the Endicott Mountains Allochthon (including the Devonian Beaucoup Formation, 
Hunt Fork Shale, and Noatak Sandstone) is also considered to be part of the Endicott Group (Fig. 5), although within the Endicott Mountains allochthon the conglomeratic unit below the Kayak Shale is referred to as the Kanayut Conglomerate rather than the Kekiktuk Conglomerate. The Kanayut also reflects a transgressive-regressive-transgressive clastic wedge succession that formed as major fluvial-deltaic depocenters migrated along the Late Devonian to Early Carboniferous basin margin (Moore and Nilsen, 1984; Moore et al., 1992). The rocks of the Endicott Mountains allochthon (and the higher grade rocks of the Hammond subterrane; Fig. 3) were transported northward and emplaced into a structural position above the rocks of the Doonerak fenster during the Brookian orogen (Fig. 3, 5, and 7; e.g. Moore et al., 1997).

These regional relationships of Middle Devonian to Lower Carboniferous rocks in the Brooks Range characterize the early rift and drift phases in the evolution of a passive margin (Anderson and Wallace, 1991; Anderson et al., 1992; Moore et al., 1992; Anderson, 1993). The presence of the sub-Mississippian unconformity above the Apoon volcanics within the Doonerak fenster is similar to what is seen in the northeast Brooks Range and North Slope subsurface; however, the unconformity is absent in the overlying Endicott Mountains allochthon (EMA). This is one line of evidence used to suggest that the rocks interior to the Doonerak fenster are in fact structural "basement” to the Brookian fold-thrust belt, despite the fact that they only achieve greenschist metamorphic grade (e.g. Moore et al., 1994). The absence of the unconformity and generally thicker and more complete stratigraphic succession in the Endicott Mountains allochthon suggests that these rocks were deposited in a more basinal position relative to their coeval equivalents in the northeast Brooks Range and Doonerak fenster. The rocks of the Endicott Mountains mark the allochthonous portion of the Brookian orogen and should be restored to a position south of the Doonerak fenster. Understanding the provenance of the 
Endicott Mountains rocks north of Doonerak would shed light on sediment pathways and variation in the Devonian section across the Brooks Range, prior to emplacement of those rocks above the Doonerak antiform.

\subsection{Overview of orogenic events in northern Alaska and the Arctic}

The Phanerozoic orogenic events of northern Alaska have historically been assigned to two major episodes, the Ellesmerian and Brookian (see review by Moore et al., 1994). Ellesmerian deformation affected units below the regionally recognizable sub-Mississippian unconformity in the North Slope subsurface and northeast Brooks Range (described in previous section) but its full extent is not well known. Lerand (1973) expanded the Ellesmerian orogeny to include all early Paleozoic deformation along the Arctic Ocean margin on the basis of presumably coeval sub-Mississippian structures in northern Alaska and the Canadian Arctic Islands. However, other work suggests that the deformation in the northeast Brooks Range is preMiddle Devonian and therefore older than the Ellesmerian structures of the Canadian Arctic (e.g. Anderson et al., 1994). The pre-Middle Devonian deformation of the northeast Brooks Range is now treated as a distinct, yet related, orogenic event, the Romanzof Orogeny (Lane, 2007). Romanzof deformation was likely localized along the northwest margin of Laurentia and could be related to the Early-Middle Devonian accretion of the Whale Mountain allochthon onto the Laurentian margin (Johnson et al., 2016; Lane, 2007). The continuity of Romanzof vs. Ellesmerian structures elsewhere in Arctic Alaska is not well known, nor are the effects of this orogenic episode on sediment dispersal among other regions of Arctic Alaska containing earlymid Paleozoic stratigraphy. 
The Brookian orogeny, the younger orogenic system of northern Alaska, formed the dominant east-west trending, north-vergent fold thrust system of the Brooks Range and occurred in two major phases (Gottschalk and Snee, 1998; Moore et al., 1994). Metamorphism of the southern Brooks Range and emplacement of far traveled thrust sheets in the northern Brooks Range occurred during the first Brookian phase in Middle Jurassic to Early Cretaceous time (Mull, 1982; Mayfield et al., 1988; Dillon 1989). The second Brookian phase formed structures in several deformational episodes affecting mid-Cretaceous and younger strata and occurred as a protracted series of deformational events. The uplift of the Doonerak antiform is attributed to this second phase (e.g. Moore et al., 1994; O’Sullivan et al., 1998). In the North Slope and Beaufort Sea, deformed Neogene and Quaternary units indicate that deformation continued into the recent geologic past (Grantz and May, 1983, Grantz et al., 1990).

Brookian deformation was also synchronous with regional metamorphism between 170 $54 \mathrm{Ma}$, concentrated around $110 \mathrm{Ma}$ (Turner et al., 1979), and contributed to the progressive uplift of the Brooks Range itself. Estimates of uplift from the Doonerak fenster in the central Brooks Range indicate 8-12 km of denudation since 70-65 Ma (O’Sullivan et al., 1998). Apatite fission-tracks suggest a minimum of $\sim 4-6 \mathrm{~km}$ of denudation since the late Oligocene (O’Sullivan et al., 1998). Similarities between the Doonerak antiform and antiforms of the northeast Brooks Range and similarly rapid rates of denudation and uplift could indicate that the Doonerak antiform formed as the result of a deformational and uplift episode that affected both regions in the Oligocene (O’Sullivan et al., 1998).

Other regional orogenic episodes (Fig. 2) which may have contributed detritus to rocks pertinent to this study include the Caledonian orogeny of Greenland, Scandinavia, and the northernmost Atlantic and the Timanian orogeny of northernmost Europe (Baltica) and Russia. 
Younger regional episodes, such as the Uralian orogeny of northern Baltica, which formed the Ural Mountains, the modern boundary between Europe and Asia, are generally too recent to have contributed detritus to rocks at Doonerak, but certainly may have overprinted portions of the Timanian fold thrust belt in northern Europe.

The Caledonian orogeny is the northern equivalent of the trans-Appalachian orogenic episodes associated with the closure of the Iapetus Ocean. It can be subdivided into numerous phases involving arc-arc and arc-continent collisions from Cambrian to Devonian time involving Laurentian, Baltican, and Avalonian crust (e.g. McKerrow et al., 2000). Early Caledonian phases are recorded in both Scandinavia and the United Kingdom and range from 550 - 500 Ma (e.g. Ramsay and Sturt, 1976; Sturt et al., 1978); however, the major collision between Laurentia and Baltica occurred from the Late Silurian to Early Devonian and is often referred to as the Scandian phase, which involved rapid subduction and the emplacement of plutonic igneous rocks between 490 - 390 Ma, with peak development around 420 Ma (e.g. Gee, 1975; Roberts, 2003; McKerrow et al., 2000). The Ellesmerian and Romanzof structures and deformation along the Canadian and Alaskan margins may be related to the Caledonian orogen. Some paleogeographic models of the Arctic predict that terranes of Caledonian origin were transported along the Laurentian Arctic Margin in a strike-slip manner (Colpron and Nelson, 2009, 2011). These Caledonian terranes might have then been incorporated into the Ellesmerian and/or Romanzof orogenic episodes and could have provided pathways for sediment to move from the Caledonian realm toward Arctic Alaska.

The Timanian orogeny is a Neoproterozoic contractional event recorded in rocks of northern and eastern Baltica, spanning about $3000 \mathrm{~km}$ from the Ural Mountains of Kazakhstan to the Varanger Peninsula of northern Norway (Fig. 2; e.g. Gee and Pease, 2004 and references 
therein). Timing of the Timanian orogen spans 800 - 550 Ma with igneous zircon from northeastern Baltica dated to 555 Ma, $\sim 620$ Ma, and $\sim 670$ Ma by Gee et al., (1995). Remizov and Pease (2004) also defined Neoproterozoic cooling ages from a zircon bearing gabbro-norite, in concert with the ages from Gee et al., (1995). Major element, trace (including rare earth) element, and isotope (Rb-Sr and Sm-Nd) geochemistry from the basement of the Pechora Basin (NW Russia) indicate that at least portions of the Timanian system are related to a juvenile island arc, indicating that subduction related arc magmatism occurred along northeastern Baltica in the Neoproterozoic (Dovzhikova et al., 2004). In northernmost Norway, on the Varanger Peninsula, rocks of the Timanides are juxtaposed against those derived from the Caledonian orogen, indicating that a suture exists between Timanian and Caledonian rocks in the Arctic (Fig. 2; e.g. Gee and Pease, 2004). The Timanides and Caledonides are both important in the context of this study because we recognize Timanian and Caledonian age detritus in Alaskan rocks of the central Brooks Range (section 4).

\subsection{The Doonerak fenster: location and basic relationships}

The Doonerak fenster is a NE-SW trending doubly plunging antiform that exposes deep structural levels of the Brooks Range (Fig. 3, 5, 6, \& 7; Dutro et al., 1976; Mull et al., 1987; Oldow et al., 1984). The fenster lies in the central part of the Brookian orogen below the basal detachment of the Endicott Mountains allochthon, the Amawk Thrust. The Endicott Mountains allochthon is a package of imbricated thrust sheets composed of Upper Devonian to Triassic siliciclastic and carbonate rocks, which are juxtaposed above Doonerak as a foreland dipping duplex (Fig. 6 \& 7; e.g. Dutro et al., 1976, 1984a; Moore et al., 1994). 
The polydeformed metamorphic core of the Brooks Range lies to the south of the Doonerak fenster, while the mildly deformed foreland thrust belt lies to its north (Fig. 7; e.g. Moore et al., 1994, 2015). Within this larger framework, the Doonerak area lies between the hinterland and foreland portions of the Brookian orogen (Fig. 3). Although the rocks at the core of the Doonerak fenster are Lower-to-Mid Paleozoic in age (Apoon Assemblage, Kekiktuk Conglomerate, Kayak Shale, Lisburne Limestone) and are overlain by allochthonous rocks also of Paleozoic age (Beaucoup Formation, Hunt Fork Shale, ect.) these two packages were not juxtaposed against each other until the Jurassic-Cretaceous Brookian orogeny. The modern antiform could have formed as recently as the Oligocene based on denudation and uplift calculated from apatite fission track data collected within the Doonerak fenster (O’Sullivan et al., 1998).

In the North Slope subsurface and northeastern Brooks Range portions of Arctic Alaska deformed lower Paleozoic and Proterozoic basement rocks similar to the Franklinian Sequence (e.g. Lerand, 1973; Carter and Laufeld, 1975) are separated from the overlying Ellesmerian Sequence by a regionally recognizable angular unconformity (Lerand, 1973; Grantz and May, 1983). In the northeast Brooks Range, the pre-Mississippian unconformity separates the Middle Devonian Ulungarat Formation from the Kekiktuk Conglomerate of the Ellesmerian Sequence (Fig. 4). Regionally, the pre-Mississippian unconformity likely formed following cessation of the Devonian Ellesmerian (or Romanzof) orogeny (Churkin, 1969, 1975; Brosgé et al., 1962; Reed, 1968; Dutro, 1970; Sable, 1977; Oldow et al., 1987a\&b; Moore et al., 1994; Lane, 2007). The lower Paleozoic volcanic and volcaniclastic rocks in the interior of the Doonerak fenster, in the central Brooks Range, are known as the Apoon assemblage (next section) and are also interpreted as structural basement of the Brookian fold-thrust belt despite their modest 
metamorphic grade (Fig. 5 and 7; Dutro et al., 1976, 1984a\&b; Armstrong et al., 1976; Dillon et al., 1986; Mull, 1982; Mull et al., 1987; Oldow et al., 1987). The basement of the North Slope subsurface and northeast Brooks Range are both different than the rocks of the Apoon assemblage, but all three are overlain by an unconformity which separates basement rocks from the Ellesmerian Sequence of passive margin siliciclastics and carbonates (Moore et al., 1994 and references therein).

\subsection{The Apoon Assemblage - Lower Paleozoic volcanic rocks}

The Apoon assemblage of the Doonerak fenster consists of the lower Paleozoic "basement” rocks below the Amawk Thrust (Fig. 5 \& 7), including volcanic and volcaniclastic rocks. The assemblage is subdivided into four poorly constrained lithologic units (Fig. 6 and 7): (1) a 500 m thick unit dominated by volcanic rocks including basaltic lava and lapilli tuff mixed with pyroclastic breccia and rare phyllites - Pza , (2) a 1500 m thick mixed clastic unit of metaargillite, phyllite, and siltstone interbedded with coarser lithologies of volcanic lithic sandstone, pebbly mudstone, and conglomerate - Pzc, (3) a highly variable $400 \mathrm{~m}$ thick volcaniclastic unit containing basaltic lava flows, interbedded tuff, and litharenite with rare phyllite and argillite Pzv, and (4) a 3000 m thick mixed slate and phyllitic unit with occasional carbonates and thin isolated lenses of aphanitic greenstone - Pzp (Julian, 1989; Julian and Oldow, 1998). All of the Apoon rocks are strongly deformed and have experienced low grade metamorphism. The true stratigraphic thickness of the Apoon assemblage is very poorly constrained due to significant isoclinal folding and structural thickening - thicknesses above are approximate structural thicknesses based on mapping in the northeastern part of the fenster (Julian and Oldow, 1998). 
Until recently, geochronologic constraints on the age of the Apoon assemblage were limited to six hornblende $\mathrm{K}-\mathrm{Ar}$ and ${ }^{40} \mathrm{Ar} /{ }^{39} \mathrm{Ar}$ cooling ages from dikes and sills that range from 520 - 373 Ma and exist in two primary groupings at 380 Ma and 470 Ma (Fig. 6; Dutro et al., 1976). Significantly, Strauss et al. (2017) conducted U-Pb SHRIMP-RG and Lu-Hf isotopic analysis on igneous zircon from a leucogabbro found in the Pzv section of the Apoon assemblage. This analysis yielded a ${ }^{206} \mathrm{~Pb} /{ }^{238} \mathrm{U}$ age of $462 \pm 8 \mathrm{Ma}$, in agreement with the $\sim 470$ Ma ages from hornblende by Dutro et al. (1976). Detrital zircons from the Apoon assemblage analyzed using LA-ICPMS methods yielded age groups of ca. 490 - 420, 540 - 520, 1250 - 960, 1500 - 1380, 1945 - 1750, and 2830 - $2650 \mathrm{Ma}$, with $\mathrm{Lu}$ - Hf data from the 490 - 420 population indicative of juvenile crust and a distinct lack of crustal assimilation during presumed Ordovician-Silurian arc magmatism (Strauss et al., 2017).

A few sporadically located paleontological collections (Fig. 6; locations 1 - 4) also provide constraints on the age of the Apoon assemblage: (1) Middle Ordovician conodonts from siliceous volcaniclastics, probably of Pzv and Lower Silurian (Llandoverian) graptolites and conodonts presumably from Pzc identified by Repetski et al. (1987), (2) Silurian graptolites from Pzc near Amawk Mountain identified by Moore and Churkin (1984), and (3) early-middle Cambrian trilobites of Siberian affinity as well as proto-conodonts, hyolithids, and acrotretid brachiopods identified by Moore et al. (1984), probably from Pzp (Figure 3; also see Supplementary Materials section for a summary of age constraints). The ages and structural relationships between different subunits within the Apoon assemblage are not well defined and could benefit from detailed stratigraphic analysis. The oldest of Doonerak’s fossils, early Cambrian trilobites of Siberian affinity, occur exclusively in the western portions of the fenster 
(Moore et al., 1984), but the effects of structural thickening and the full suite of lithologies present in not well known.

Limited geochemical data from igneous rocks of the Apoon assemblage indicate compositions consistent with a magmatic arc complex and show similarities to the chemistry of volcanic rocks in the northeastern Brooks Range (Julian and Oldow, 1998; Moore et al., 1997; Moore, 1987). Despite some alteration, analyses from Pza and Pzv both show compositional overlap between major and trace element geochemical fields associated with calc-alkaline basalts, island-arc thoeliites, and mid-ocean ridge basalts (MORBs; Julian and Oldow, 1998; Moore, 1987; Julian 1989; Moore et al., 1997). These previous geochemical arguments by Julian and Oldow (1998) provide a good starting point for assessing the tectonic setting of the Apoon assemblage. Previous studies only considered a handful of trace element ratios and did not incorporate rare earth element trends or a sufficient diversity of trace elements, which are resistant to alteration by hydrothermal and metamorphic processes (Julian and Oldow, 1998; Moore et al., 1997; Moore, 1987). The detailed structure within the fenster and age relationships between these different igneous rocks are currently only known at a general level, which prevents determining if the variability within the geochemistry of these samples is the product of a genetically related series of melts or multiple distinct magma series.

Several important geologic features coexist within the Doonerak fenster: (1) Siberian fossils in the westernmost part of the fenster with (2) stratigraphic relationships indicative of Laurentian origin in the eastern part of the fenster - the sub-Mississippian unconformity overlain by the Ellesmerian Sequence as seen in the North Slope subsurface and (3) the presence of a wide range of potentially arc-related Early Paleozoic volcanic rocks within the Apoon assemblage. These data suggest that the Apoon assemblage of the Doonerak fenster could 
represent an early Paleozoic magmatic arc succession based on limited lithological, geochemical, geochronological, and paleontological data, but its tectonic setting and full significance relative to the regional context of Arctic Alaska is unclear (Dutro et al., 1976; Moore, 1987; Julian, 1989; Julian and Oldow, 1998; Strauss et al., 2017). Previous workers have shown that the Doonerak area is a structural window (fenster) which exposes deep levels of the Brooks Range and that the Apoon assemblage is unlike other exposures in the central Brooks Range (e.g. Dutro et al., 1979; Moore et al., 1994; Moore et al., 1997). Limited geochemical data are inconclusive, but suggest that the Apoon assemblage may have formed in a subduction zone (Julian and Oldow, 1998; Moore et al., 1997). As such, the Doonerak fenster may delineate the boundary/suture between Laurentian and non-Laurentian rocks in Arctic Alaska, but more data is needed to address this hypothesis. Basic structural relationships, the general diversity of various map units, the textural and compositional diversity of the Apoon volcanics, and the provenance of various siliciclastic units all remain poorly constrained and are addressed in this study.

\section{METHODS}

\subsection{Methodological goals}

The goal of this study is to provide evidence which can be used to determine the tectonic setting of the Apoon assemblage of the Doonerak fenster and to better understand the relationship of the units exposed in Doonerak fenster to the rocks structurally emplaced above it, the Endicott Mountains allochthon. In order to do so, we constrained the age and provenance of detrital rocks from both above and below the basal detachment of the Endicott Mountains allochthon, the Amawk thrust, using U-Pb detrital zircon geochronology applied to the Apoon 
assemblage, Ellesmerian Sequence and Endicott Group. Whole rock major and trace element geochemistry are used to define the tectonic setting in which the Apoon assemblage formed.

Fieldwork was conducted along the North Fork Koyukuk River, a throughgoing stream which passes through both the Endicott Mountains and the Doonerak Fenster. Fieldwork focused on an area which is approximately $17 \mathrm{~km}$ x $8.5 \mathrm{~km}$ centered on the North Fork Koyukuk River within the Gates of the Arctic National Park (Fig. 8). The following sections present data primarily focused on six sandstone samples collected for detrital zircon analysis and eleven igneous samples collected for geochemical analysis. The Supplementary Materials section of this document contains a table with a full list of all samples collected, basic descriptions and collection locations.

\subsection{U-Pb Detrital Zircon Geochronology}

$\mathrm{U}-\mathrm{Pb}$ detrital zircon geochronology is a common tool for understanding the provenance and depositional age of sedimentary rocks (e.g. Dickinson and Gehrels, 2003; DeGraaf-Surpless et al., 2002; see review by Gehrels, 2014). Because zircon is mechanically and chemically resistant to breakdown it is commonly incorporated as a minor constituent in clastic sedimentary rocks. Dating zircons from a sedimentary rock provides information about that rock’s depositional age and provenance. This can be achieved by comparing the ages calculated from detrital zircon within the rock in question to the ages of potential source regions that may have contributed primary igneous or metamorphic zircon grains as detritus. The $\mathrm{U}-\mathrm{Pb}$ method is capable of capitalizing on three separate, yet related, radioactive geochronometers $\left({ }^{238} \mathrm{U} \rightarrow{ }^{206} \mathrm{~Pb}\right.$, $t_{1 / 2} \sim 4.47 \mathrm{Ga} ;{ }^{235} \mathrm{U} \rightarrow{ }^{207} \mathrm{~Pb}, t_{1 / 2} \sim 0.70 \mathrm{Ga} ;{ }^{233} \mathrm{Th} \rightarrow{ }^{208} \mathrm{~Pb}, t_{1 / 2} \sim 14.01 \mathrm{Ga}$; Jaffey et al., 1971 ). 
There are several analytical methods for measuring the abundance of various $\mathrm{U}, \mathrm{Th}$, and $\mathrm{Pb}$ isotopes within a zircon grain. Laser ablation-inductively coupled plasma-mass spectrometry (LA-ICP-MS) is commonly used to analyze large suites of zircon grains from sedimentary rocks because it is rapid, cost effective, and maintains precision and accuracy of 1-2\% (e.g. Gehrels, 2014; Košler et al., 2013). This method uses a laser beam to ablate zircon material from a polished sample of zircon grains, extracted from the rock in question. The ablated material is fed into a stream of gas which flows into a mass spectrometer, where isotope analysis is conducted (e.g. Fryer et al., 1993; Košler et al., 2001; Košler and Sylvester, 2003). Zircon grains of a precisely known age (calculated by ID-TIMS) are used as standards and are periodically analyzed alongside unknown grains from the rock of interest in order to correct for downhole fractionation. ${ }^{206} \mathrm{~Pb} /{ }^{238} \mathrm{U}$ ratios can be affected by fractionation during sample ablation. This periodic analysis of standard and unknown grains is referred to as standard-sample bracketing (e.g. review by Gehrels, 2014). Isotope ratios can then be used to calculate an age for each ablated zircon from the rock in question. The analyzed zircon grains are treated as a representative sample of the total population of detrital zircons within the rock of interest. Ideally, approximately one hundred to three hundred unknow zircon grains should be analyzed from each sample to allow for robust statistical treatment; however, it is common to report analyses with as few as 80 successful ages (e.g. review by Gehrels, 2014).

Six samples of sandstone from the vicinity of the Doonerak fenster in the central Brooks Range (both from the fenster itself and the overlying allochthonous package) were analyzed for U-Pb detrital zircon geochronology by LA-ICP-MS at the University of South Carolina’s Center for Elemental Mass Spectrometry (CEMS). Each sample consisted of approximately 0.5 - $1.0 \mathrm{~kg}$ of rock collected from single beds. The coarsest fractions were 
targeted because they have a greater likelihood of containing abundant usable zircon. Care was taken to avoid veins, weathering rinds and other potential sources of alteration or contamination. Processing of the raw data generated by the mass spectrometer during LA-ICP-MS analysis was conducted using the UPbGeochronology3 data reduction scheme of the Iolite v.3 software suite (Paton et al., 2010) within the IgorPro data and computation package. Individual ages were then filtered based on the concordance, ${ }^{206} \mathrm{~Pb} /{ }^{207} \mathrm{~Pb}$ and ${ }^{206} \mathrm{~Pb} /{ }^{238} \mathrm{U}$ ratios, total $\mathrm{U}$ and $\mathrm{Th}$ concentrations, and the degree of uncertainty in the resulting calculated ages. Concordance refers to the level of agreement between the ${ }^{207} \mathrm{~Pb} /{ }^{235} \mathrm{U}$ and ${ }^{206} \mathrm{~Pb} /{ }^{238} \mathrm{U}$ ages calculated from a single grain. A concordance filter of $85 \%$ and a reverse concordance filter of $105 \%$ was used as the acceptable cutoff, typical of detrital applications (e.g. Gehrels, 2014). The Sri Lanka (SL) zircon standard was used as the primary reference material for all analyses presented in this study (TIMS age $=563.5 \pm 2.3 \mathrm{Ma}, 2 \sigma ; 518 \mathrm{ppm} \mathrm{U}, 68 \mathrm{ppm} \mathrm{Th},{ }^{206} \mathrm{~Pb} /{ }^{204} \mathrm{~Pb}=18000$; Gehrels et al., 2008). The zircon standard 91500 (ID-TIMS age $=1065 \pm 5$ Ma; Wiedenbeck et al., 1995) was used as the secondary reference material. For consistency and comparability all ages reported are based on the reduction scheme using SL as the primary reference material. During analysis, both reference materials were analyzed following ablation of every five unknowns.

The resulting filtered data is presented herein as normalized age-probability density plots which were created using the program IsoPlot v.3. Individual sample information, full geochronologic data tables, procedures for sample collection, preparation, interpretation, $\mathrm{U}-\mathrm{Pb}$ concordia diagrams (Wetherill, 1956), and accompanying descriptions for each sample are provided in the Supplementary Materials section of this document. The entire U-Pb data collection and processing procedure was conducted under the advisement of Dr. David Barbeau from the University of South Carolina. 


\subsection{Whole Rock Volcanic Geochemistry}

Magmas contain distinctive trace element compositions which can be used to differentiate between basalts erupted from different tectonic settings (e.g. Pearce, 1983). More specifically, the characteristic enrichments and depletions of trace elements within these magmas

can be used to provide clues to identify the source and processes responsible for magma formation. For instance, enrichment in large ion lithophile elements (LILEs; e.g. Cs, Rb, K, Ba, $\mathrm{Pb}, \mathrm{Sr}, \mathrm{Th}$ ) and depletion of high field strength elements (HFSEs; e.g. Nb, Zr, Ti, Ta, P) in arc basalts are the result of metasomatic processes between the subducting lithospheric slab and the overlying mantle wedge and are highly indicative are arc-related tectonic settings (e.g. Tatsumi, 2005). Similarly, the systematic chemical behavior of rare earth elements (REEs) makes them a highly effective tool for determining the tectonic setting in which mafic to intermediate igneous rocks may have formed and the various petrogenic and alteration processes that may have affected them (e.g. Hanson, 1980; Pearce and Cann, 1973; Winchester and Floyd, 1977; Bacon et al., 1997; and many others). REE cations systematically decrease in size with increasing atomic number (from La to Lu) the distribution coefficients and partitioning behavior of REEs, a product of charge and size of an ion relative to crystal lattice sites, also vary systematically (e.g. Blundy and Wood, 1994; Hanson, 1980; Davidson et al., 2013). As such, petrogenetic processes (i.e. partial melting, fractional crystallization, melt mixing) affect REE patterns based on systematically variable properties dictated by variations in ionic radius and the abundance of particular mineral phases capable of incorporating REEs into their structure.

Eleven samples of igneous rock from the Apoon Assemblage of the Doonerak fenster were analyzed for whole rock major, trace, and REE geochemical abundances. Samples were 
prepared and powered in the rock preparation laboratory at West Virginia University using standard practices and analyzed by a professional commercial laboratory (Activation Laboratories, Ontario, CA - Analysis type: Whole Rock Analysis + ICP 4 Lithoresearch QUANT). Care was taken to avoid weathering rinds and obviously altered rock surfaces. All samples were treated with an aggressive fusion technique and then digested in an acid solution, which is required to totally dissolve the entire sample and adequately assess major oxides, refractory minerals, REEs, and other high field strength elements. Analysis was conducted by ICP-OES and ICP-MS. A full table of results, detection limits, and individual sample descriptions is provided in the Supplementary Materials section of this document.

This work expands on that of Moore (1987), who compared the Apoon volcanics to volcanic rocks of the northeast Brooks Range, and Julian and Oldow (1998), who suggested that the lithogeochemistry of rocks in the northeastern part of the Doonerak fenster was indicative of a magmatic arc complex along an active continental margin. Several of the basalt discrimination diagrams used by Julian and Oldow (1998) are presented alongside the new data from this study in order to allow for direct comparison. Neither previous study considered the full suite of trace and REE trends presented herein. The new REE data presented in this study is also presented alongside representative data from global databases to aid in the comparison of geochemical trends. The N-MORB, E-MORB, OIB, and depleted mantle chemistry of Sun and McDonough (1989), Salters and Stracke (2004), and McDonough and Sun (1995) respectively is provided to aid in comparison and qualitatively compare different source regions. Focus is given to variation (spider) diagrams of trace and REEs because rocks of the Apoon assemblage have experienced hydrothermal and/or low grade metamorphic conditions, which complicate the interpretation of trends based on major elements or those based on other fluid mobile elements. Trace elements, 
particularly REEs, are relatively immobile under hydrothermal and low grade metamorphic conditions, making them a more reliable means to assess these particular rocks (e.g. McLennan, 1989). The primary goal of these geochemical analyses is to define the likely tectonic setting in which the Apoon rocks formed.

\section{RESULTS}

\subsection{Field Relationships, sample collection, and lithologic characteristics}

Figure 8 provides an updated geologic map of the area containing the locations of samples analyzed for whole rock geochemistry and detrital zircon geochronology. Note that most samples and field data come from an area which is approximately $17 \mathrm{~km} \mathrm{x} 8.5 \mathrm{~km}$ and focused around the North Fork Koyukuk River; however, one sample (J1415) was provided by J. Strauss northeast of all the other samples. The field relationships mapped in direct proximity to that sample come from their observations and mapping (see Strauss et al., 2017). The nomenclature on this map generally follows that of Julian and Oldow (1998) and Strauss et al. (2017). Some contacts and structures are inferred from aerial and satellite imagery. Some contacts are projected onto this map from the east where Strauss et al. (2017) conducted field work.

One of the most important field relationships observed during the 2015 field season along the North Fork of the Koyukuk River was confirmation of the presence of the sub-Mississippian unconformity between rocks of the Ellesmerian Sequence and rocks of the Apoon assemblage within the Doonerak fenster (below the Amawk thrust). Along the North Fork of the Koyukuk River east of its confluence with Ernie Creek the river's flow direction changes from E-W to NS. Just upstream of that bend in the river, rocks of the Lisburne Limestone are easily visible at 
the field scale as a dip slope on the south side of the river valley. Figure 10 provides an annotated field photo with a view to the east along this strategic portion of the North Fork of the Koyukuk River. To the north (left) side of the image, rocks of the Devonian Hunt Fork formation (Endicott Mountains allochthon) are exposed among rolling tan-gray hills. This is the approximate location of sample 26DF15, which was collected for detrital zircon geochronology (next section). The south (right) side of the image shows the Ellesmerian Sequence, including the Lisburne Limestone and Kayak Shale (Doonerak Fenster), and the Ordovician to Silurian age rocks of the Apoon assemblage. This is the approximate location of sample 23DF15 (Kayak fm), which was also collected for detrital zircon analysis (next section). At this location, the Kayak Shale sits unconformably atop the Apoon assemblage. Elsewhere within the fenster, the Kekiktuk Conglomerate, stratigraphically below the Kayak Shale (see Fig. 4 \& 5), is described as resting in direct unconformable contact with the Apoon assemblage (e.g. Dutro et al., 1976; Julian, 1989; Strauss et al., 2017). This implies some variation along strike of this important contact. That variability has not been acknowledged previously and is different from what is observed in the northeast Brooks Range and North Slope subsurface. The abrupt craggy edifices making resistant peaks to the right (south) side of the image are composed of the Apoon igneous rocks (Fig. 10).

Stereographic projections of poles to the dominant foliation, $S_{1}$, of various outcrops are provided in Figure 11 (A - D), which is organized based on lithology. Interior to the fenster, rocks of the Kayak Shale and Lisburne Limestone (Ellesmerian Sequence in Fig. 11 - C) have poles to bedding, $\mathrm{S}_{0}$, that indicate planes which dip consistently to the north and northwest; however the underlying rocks of the Apoon assemblage do not follow the same orientation (Fig. 11 - D). The attitude of the Apoon units is significantly more variable. Immediately south of the 
sub-Mississippian unconformity, the Apoon units dip to the south opposite those of the Ellesmerian Sequence. Yet, in close proximity the same units strike north-south and dip to the west (see Fig. 8). The relationship and angle between cleavage and bedding (where both were identified) did not remain consistent throughout the area, being near parallel to each other in some places and at a steep angle to each other in others, indicating that the primary bedding planes are folded. Rocks of the Hunt Fork Formation (northern portions of Fig. 8) generally dip to the west and northwest with rare southward dipping structures (Fig. 11 - A). The underlying Beaucoup Formation, which occupies the hanging wall of the Amawk Thrust, contains chaotically organized fabrics (Fig. 11 - B), but generally mimic the orientation of the overlying Hunt Fork Shale.

Some structural features observed in the field exist below the scale of the map in Figure 8 and are not immediately apparent from the aggregated structural data (Fig. 11 A - D). Specifically, two upright, open outcrop scale anticlines were observed along the west side of the North Fork Koyukuk River, north of Frigid Crags and south of Shushalch Creek, near sample location 43 in Figure 8. Both folds were observed within the Beaucoup Formation in the hanging wall of the Amawk thrust, about $2.5 \mathrm{~km}$ from each other (Fig. 12). It was clear that these two anticlines deformed bedding because the lithologies at their centers differed from those at their edges. The axial planes of each of these folds strike approximately east-west or northeastsouthwest (Fig. 12) and dip to the south or southeast, broadly similar to Brookian deformational trends regionally.

The Apoon assemblage contains a diversity of complex structures and lithologies that are easily recognized at the outcrop scale. There are multiple field examples of the internal complexity of the Apoon assemblage, both lithologically and structurally (Fig. 13). Small folds 
deforming bedding in multiple orientations, folds superimposed over a preexisting cleavage, and various brittle structures (i.e. small faults and joints) suggest that the Apoon Assemblage experienced multiple episodes of deformation, some of which likely predate that observed within the Endicott Mountains allochthon (the Brookian structures). Along Pyramid Creek (Fig. 8), small scale ( $0.5 \mathrm{~m}$ wide) isoclinally folded beds of sandstone are exposed on the ground along a pavement outcrop (Fig. 13 - A). These small folds bend gray slate and $3-10 \mathrm{~cm}$ thick sandy beds. They have approximately vertical axial planes parallel to the dominant cleavage, angular hinges, and are crosscut by occasional northwest dipping dolomitic veins. This is markedly different from the broad, nearly upright, open folds seen further up the Pyramid creek drainage (Fig. 13 - C). This other set includes folds that deform a pre-existing foliation within units of mostly slate. The folds are approximately 2 - $10 \mathrm{~m}$ wide with rounded hinges and a gentle plunge to the northwest (Fig. 13 - C). South of Pyramid Creek (Fig. 8) an en echelon array of veins define a small normal fault zone separating tuff from slate within the Apoon assemblage (Fig. 13 - B). The clastic portions of the Apoon assemblage (Fig. 13 - D, E, and F) are widely variable lithologiocally and include slates, tuffs, sandstones, and phyllites.

The volcanic/igneous rocks of the Apoon assemblage show a wide variety of textures and field relationships (Fig. 14 A - F). Some clearly intrusive contacts were observed along Pyramid Creek (Fig. 14 - A and B) where sills of andesite, crosscut by veins of quartz and calcite, intruded the gray slates and sandstones of the Apoon clastics (Pzc). South along Boreal Mountain, a large igneous edifice deflects the surrounding phyllitic rocks and contains basalticandesite with large laths of plagioclase visible to the unaided eye (Fig. 14 - D). In contrast, the region north of Pyramid Creek is dominated by fine grained basaltic greenstone and only minor slates and clastics (Fig. 14 - F). Along Bombardment Creek, basaltic pillows form a massive (15 
- 20 m tall) cliff (Fig. 14 - C). The same area contains out-of-place blocks of brecciated greenstone, which resembles a flow top igneous breccia (Fig. 14 - E).

The downstream portions of Bombardment Creek transect the Ellesmerian Sequence and expose gently folded limestone beds among the Kayak Shale and massive beautifully folded gray Lisburne Limestone high above the creek (Fig. 15). Rare crinoids were observed within the Kayak Shale (Fig. 15 - B). North of Pyramid Creek, along strike of Bombardment Creek, the Lisburne Limestone forms a massive slope south of the North Fork Koyukuk River and exposed bone gray micritic limestone with large black chert nodules (Fig. 15 - C and D).

In the northernmost part of the map area (Fig. 8), the Devonian Hunt Fork Shale outcrops among rolling tan-gray hills north of the North Fork Koyukuk River (Fig. 16). In this area the Hunt Fork dips consistently to the north and northwest; however older published maps suggest that its attitude changes to southeastward dipping strata just north of this study area (Fig 8; Dillon et al., 1986). At the outcrop scale, the Hunt Fork contains tan to brown-black shale and slate interbedded with brown fine grained sandstone and quartzite as well as rare lenses of brown limestone (Fig. 16 - C and D). To the west of the confluence between Ernie Creek and the North Fork Koyukuk River and to south of Shushalluk Creek, the Hunt Fork passes conformably up section into the Noatak Sandstone and Kanayut Conglomerate (Fig. 16 -A and B). The Noatak Sandstone was poorly expressed within a mostly covered interval; however the overlying Kanayut Conglomerate was present as a massive quartz-chert pebble conglomerate within interbedded sandstones (Fig 16 - A). Aerial and satellite imagery was used to supplement field observations and produce the contact relationship seen in Figure 8. This is the approximate location of sample 41DF15 (Kanayut Conglomerate), which was collected for detrital zircon analysis (next section). 
The following section contains observations and data from samples collected for detrital geochronology and whole rock major and trace element geochemistry. These data are presented within Figures 17 - 22. All analyzed sample information is presented within the supplementary materials along with information on other samples collected, but not analyzed, during this study. This document focus on samples used for detrital zircon geochronology (six samples) and whole rock volcanic geochemistry (eleven samples), other samples (45 in total) are appropriate for other analyses. These may include assessment of deformational fabrics, Ar-Ar dating of detrital and potentially authigenic white mica along cleavage planes, and laser raman spectroscopy of carbonaceous material (forthcoming thesis by Greg Hammond will address estimates of maximum paleotemperature based on this technique). All samples could benefit from more detailed petrographic analysis, as this was only conducted on a preliminary basis for most samples in the course of the current project.

\subsection{Detrital Zircon Geochronology}

Six clastic samples (Figs. 8) were collected from the vicinity of the North Fork Koyukuk River in the Gates of the Arctic National Park, AK for laser ablation analysis and detrital zircon geochronology. Samples presented here are organized based on their sampling locations and respective formations. For instance, samples 05DF15 and 23DF15 (Fig. 8) represent the Apoon Assemblage and Kayak Formation respectively. These two samples come from the interior of the Doonerak fenster, definitively below the Amawk thrust. Samples 43DF15 and J1415 (Fig. 8) represent the Beaucoup Formation and come from the complicated northern margin of the fenster, where field relationships and contacts are difficult to decipher and there may be complication by faulted slivers of Apoon, EMA, and/or Hammond Terrane rocks. Samples 
41DF15 and 26DF15 (Fig. 8) represent the Hunt Fork Shale and Kanayut Conglomerate respectively and come from the Endicott Mountains allochthon, north of and definitively above the Amawk thrust. The following sections contain details regarding the detrital zircon geochronology of the samples outlined above. All geochronologic data presented in Figures 1823 and Figures 29-32 contain U-Pb analyses that have met the necessary filtering conditions outlined in the methods section based on concordance and abundance of various $\mathrm{U}$, Th, and $\mathrm{Pb}$ isotopes and isotope ratios (e.g. Gehrels, 2014; more details provided in the Supplemental Materials section).

Fenster Interior: Apoon Assemblage and Kayak Shale

Sample 05DF15 is an impure lithic sandstone collected from the Apoon assemblage along a ridge south of Pyramid Creek and to the east of the North Fork Koyukuk River (Fig. 8; 67.861869 N, -150.787034 W). In hand sample and thin section it is poorly sorted and contains subrounded grains of quartz and K-feldspar, masses of microcrystalline quartz, minor chert fragments, and angular volcanic lithic fragments with clasts reaching an approximate maximum size of 0.6 mm (Fig. 17 - A and B). Detrital zircon spectra from 05DF15 (Fig. 18) are based on 96 successful zircon analyses. The maximum depositional age for 05DF15, calculated as a weighted mean of the six youngest zircon grains that fall within error of each other, is $452 \pm 13$ Ma (MSWD = 0.76). Probability density plots from sample 05DF15 (Fig. 18) show a dominant unimodal peak centered on 504 Ma. Other minor detrital populations are present at 601, 764, 1153 - 1370, 1455 - 1565, 1764 - 1942, 2308, 2500 - 2624, and 2683 - 2875 Ma. 
Sample 23DF15 is a sandstone of the Ellesmerian sequence (Kayak Fm.), which was collected from the south side of the North Fork Koyukuk River between its confluence with Ernie Creek and Bombardment Creek (Fig. 8; 67.907896 N, -150.752165 W). It is a moderately sorted sandstone (Fig. 17 - E and F) containing subrounded to angular monocrystalline and polycrystalline quartz grains, with some grains showing undulose, or wavy, extinction within a fine dark matrix. It also sporadically contains throughgoing bands of mica which appear to define cleavage planes and extend along the boundary of some grains (Fig. 17 - F). Detrital spectra from 23DF15 (Fig. 19) are based on 108 successful zircon analyses. The maximum depositional age for 23DF15, calculated as a weighted mean of the six youngest zircon grains that fall within error of each other, is $385.6 \pm 8.9 \mathrm{Ma}(\mathrm{MSWD}=0.70)$. Probability density plots from sample 23DF15 (Fig. 19) show a dominant polymodal peak centered on 405 and 441 Ma. Other detrital populations are present at 573, 773, 931, 980 - 1250, 1310 - 1470, 1710 - 2160, 2260 - 2410, and 2460 - 2660 Ma.

Fenster Margin: Beaucoup Formation

Sample J1415 is a lithic/conglomeratic sandstone of the Beaucoup Formation, which was collected from an area approximately 10 miles east of the other samples. It was collected by J. Strauss from the east side of the North Fork Koyukuk River, north of the headwaters of Saint Patrick’s Creek (Fig. 8; 67.938861 N, -150.427833 W). In hand sample, J1415 contained stretched grains of chert and quartz within a noticeable pervasive fabric. In thin section it contains many small thoroughgoing fractures and veins among subrounded clasts of quartz, plagioclase, with rare mica and opaques (Fig. 17 - I and J). Detrital zircon spectra from J1415 
(Fig. 20) are based on 121 successful zircon analyses. The maximum depositional age for J1415, calculated as a weighted mean of the six youngest zircon grains that fall within error of each other, is $360.1 \pm 7.4 \mathrm{Ma}$ (MSWD = 0.117). Probability density plots from sample J1415 (Fig. 20) show a dominant unimodal peak centered around $426 \mathrm{Ma}$. Other detrital populations are present at 360, 507, 835 - 1000, 1203 - 1520, 1610 - 1924, 2373, 2475, 2601 - 2724, 2843, and 3179 3280 Ma.

Sample 43DF15 (Fig. 17 - G and H) is a slightly sheared lithic sandstone probably of the Beaucoup Formation (see discussion section), which was collected from the west banks of the North Fork Koyukuk River, south of the confluence with Ernie Creek (Fig. 8; 67.889526 N, 150.935793 W). This unit was mapped as part of the Hunt Fork formation in the field by Dillon et al., (1986) and rests near the Beaucoup - Hunt Fork contact, as drawn in this study. 43DF15 is a fine grained sandstone containing subrounded clasts of quartz and feldspar (Fig. 17 - G and H). It also contains obvious thoroughgoing bands of mica, partitioned onto cleavage planes. The sample was not collected oriented spatially, but grains appear to have rotated slightly within this pervasive banded framework, indicating some component of shear. Detrital zircon spectra from 43DF15 (Fig. 21) are based on 126 successful zircon analyses. The maximum depositional age for 43DF15, calculated as a weighted mean of the six youngest zircon grains that fall within error of each other, is $397.1 \pm 6.4 \mathrm{Ma}$ (MSWD $=0.17)$. A single anomalously young grain $(340.4 \pm 14$ Ma) was not included in this calculation because it does not fall within error of the other youngest grains. Despite careful steps taken to avoid contamination, it is possible that this single grain is exotic to this sample. Therefore, no interpretations were made based on the age of this single grain. It is presented here and within the data tables because there was no impartial means by which to exclude it based on concordance, isotope ratios, or isotope abundances. Probability 
density plots from sample 43DF15 show a dominant unimodal peak centered around 420 Ma. Other detrital populations are present at 506, 548, 646, 702, 875, 995-1240, 1600-1830, and 2760 Ma.

Endicott Mountains Allochthon: Hunt Fork and Kanayut Formations

Sample 26DF15 (Fig. 17 - C and D) is a sandstone of the Hunt Fork formation, which was collected from the north side of the North Fork Koyukuk River between its confluence with Ernie Creek and Bombardment Creek (Fig. 8; 67.933120 N, -150.778276 W). Sample 26DF15 was collected from a sandy fraction interbedded among the tan-gray shales/slates of the Hunt Fork. It is a fine grained sandstone containing rounded and subrounded grains of quartz, potassium feldspar, plagioclase, and opaques (Fig. 17 - C and D). Detrital zircon spectra from 26DF15 (Fig. 22) are based on 86 successful zircon analyses. The maximum depositional age for 26DF15, calculated as a weighted mean of the six youngest zircon grains that fall within error of each other, is $372 \pm 12$ Ma (MSWD = 0.17; Fig. 22). Probability density plots from sample 26DF15 (Fig. 21) show a dominant unimodal peak centered on 429 Ma. Other detrital populations are present at 372, 570, 630, 930 - 1100, 1240 - 1370, 1600 - 2175, and 2375 - 2730 Ma.

Sample 41DF15 is a lithic/conglomeratic sandstone of the Kanayut Formation, which was collected upslope of Shusaluk Creek, to the northwest of the confluence between Ernie Creek and the North Fork Koyukuk River (Fig. 8; 67.918660 N, -150.929762 W). In the field it was collected from a large $10 \mathrm{~m}$ x $10 \mathrm{~m}$ bounder near the top of the slope. This was done because the 
terrain became impassible, but large in place blocks of Kanayut were visible just upslope from where this sample was collected. It is a quartz and chert pebble rich conglomerate with some potassium feldspar and well-rounded clasts held within a sandy matrix (Fig. 16 - A). Detrital spectra from 41DF15 (Fig. 23) are based on 127 successful zircon analyses. The maximum depositional age for 41DF15, calculated as a weighted mean of the three youngest zircon grains that fall within error of each other, is $339 \pm 17 \mathrm{Ma}$ (MSWD = 0.19). Three anomalously young grains (shaded gray in Fig. 23) which did not fall within error of each other were not included in calculation of the maximum depositional age (265.2 $\pm 11 \mathrm{Ma}, 283.9 \pm 11 \mathrm{Ma}, 305 \pm 15 \mathrm{Ma})$. Probability density plots from sample 41DF15 (Fig. 23) show a dominant unimodal peak centered around 428 Ma. Other detrital populations are present at 339, 364, 600, 721, 960, 1120, 1800 - 2000, and 2510 Ma.

\subsection{Whole Rock Volcanic Geochemistry}

The geochemical trends of volcanic rocks can be used to provide information on the tectonic setting in which they formed (e.g. Pearce, 1983; Tatsumi, 2005). Eleven igneous rock samples from the Apoon assemblage were analyzed for major, trace, and rare-earth element (REE) compositions. The geochemical data presented here is the first to include REE abundances from the Apoon assemblage and complements the work of Julian and Oldow (1998).

Major element data from are shown in the Supplemental Materials section. Data reports from Activation Laboratories (Ontario, CA) are included as well as the loss on ignition (LOI), the volatile abundance driven off during sample fusion. All of the major element abundances were recalculated to $100 \%$ without volatiles $\left(\mathrm{H}_{2} \mathrm{O}\right.$ or $\left.\mathrm{CO}_{2}\right)$ for all pertinent figures and calculations. This was done so that all major element plots compare samples on the same 
anhydrous basis, but the raw data is given in the Supplementary Materials section. Not all samples from this study have geochemical compositions that are suitable for use in all of the geochemical plots (i.e. basalt discrimination diagrams were only applied to samples with suitable major element compositions). The samples that contained $\mathrm{SiO}_{2}$ (wt \%) and $\mathrm{CaO}+\mathrm{MgO}$ (wt \%) abundances which prevent them from being classified as basalts or basaltic-andesites by the system of Pearce and Cann (1973) were not included in the basalt discrimination diagrams, but they were included in trace and rare-earth element variation diagrams. These high silica samples include 03DF15 (59.32\% $\mathrm{SiO}_{2}$ norm.), 11DF15 (62.16\% $\mathrm{SiO}_{2}$ norm.), $13 \mathrm{DF} 15$ (57.91\% $\mathrm{SiO}_{2}$ norm.), and 33DF15 (60.51\% $\mathrm{SiO}_{2}$ norm.). Among these, sample 33DF15 was distinct due to its ophitic to subophitic texture in thin section and large laths of plagioclase, as such this sample could not be classified as a basalt. Because all samples have experienced hydrothermal alteration and low grade regional metamorphism, emphasis is given to trace and rare-earth element geochemical trends, which are typically less susceptible to alteration than the major elements. As such, fluid-mobile elements (e.g. LILE) are used with precaution.

For comparison, representative basalt samples are presented alongside geochemical analyses in all trace and REE geochemical plots. These include island arc basalts (IABs; Sun and McDonough, 1989), normal and enriched mid ocean ridge basalts (NMORBs and EMORBs; Sun and McDonough, 1989), and ocean island basalts (OIBs; Nye and Reid, 1984).

\section{$\underline{\text { Basic Classification - Major Elements and Thin Sections }}$}

Figure 24 is a total alkali - silica diagram, comparing the abundance of $\mathrm{SiO}_{2}$ (wt \%) and $\mathrm{CaO}+\mathrm{MgO}$ (wt \%) after Le Maitre et al., (2002). The dotted line represents the boundary 
between alkaline and subalkaline compositions. The fields marked by solid lines denote IUGS classification of volcanic rock type based on the comparison of these major elements. In general, the Apoon Assemblage contains a diverse suite of igneous rock compositions, spanning 45 to $64 \mathrm{wt} \% \mathrm{SiO}_{2}$ (Fig. 24). All of the collected samples $(\mathrm{n}=11)$ from the Apoon Assemblage are classified as subalkaline basalts, basaltic-andesites, and andesites. Although two samples plot within the trachy-andesite field, they are still classified as subalkaline.

The five low $\mathrm{SiO}_{2}$ samples (e.g. 45-52 wt\% $\mathrm{SiO}_{2}$; 01DF15, 08DF15, 25DF15, 32DF15, and 38DF15) are plotted together (Fig. 26A and 27A). Similarly, the moderate-to-high silica samples (e.g. 55- 63 wt\% $\mathrm{SiO}_{2}$; 03DF15, 11DF15, 13DF15, 21DF15, 24DF15, and 33DF15), are grouped together in the subsequent variation diagrams (Fig. 26B and 27B). Comparing these classifications to the spatial distribution of these samples (Fig. 8), highlights no discernable trends related to location within the fenster. South of Pyramid Creek sporadic dikes and sills crosscut clastics, including lithic sandstones and phyllites. In areas north of Pyramid Creek, the clastics are less abundant and massive outcrops of flows and pillows are found along Bombardment Creek. These textural and lithologic variations are visible sample-to-sample but the range of major element compositions observed does not follow any discernible spatial or lithologic pattern.

The igneous rock samples of the Apoon assemblage show wide variability in their textures and mineralogical character, ranging from ophitic/subophitic (Fig. 25 - A and B) to glassy and mildly vesicular (Fig. 25 - G, H, I and J). A mild pock-marked, texture was found on some plagioclase laths within sample 33DF15 (Fig. 25 - A and B) is not concentrated on the edge of grains and appears to muddle grain interiors, possibly as a result of some process during crystallization (trapping fluids or gasses). The thin sections also provide some corroborating 
evidence of hydrothermal alteration. Many samples (e.g. 38DF15 and 01DF15) showed partial to extensive replacement of plagioclase feldspar by carbonate. Birefringent carbonate was ubiquitous across multiple samples, an example of which is visible in Figure $25 \mathrm{C}$ and $\mathrm{D}$. The birefringent carbonate and replacement of plagioclase is direct evidence for the alteration of primary mineral phases and suggests that some geochemical trends, especially major element trends, may have been affected by secondary alteration. Because many of the Apoon Assemblage rocks show evidence of hydrothermal alteration, fluid-mobile elements (e.g. LILE) are used with caution. However, these elements, along with other fluid-immobile trace elements (HFSE and REE) are evaluated in the next section. Greater emphasis is placed on the HFSE and REE elements. These are viewed alongside the fluid-mobile elements (LILE) for completeness and to better characterize geochemical trends within the collected rocks.

\section{Variation/Spider Diagrams - Trace and Rare Earth Element Trends}

Figure 26 (Trace element; NMORB normalized) and Figure 27 (REE; chondrite normalized) are variation diagrams for the Apoon Assemblage whole rock geochemical samples, based on the normalization and plotting scheme of Sun and McDonough (1989). Each of these figures (Fig. 26 and 27) separates the five low $\mathrm{SiO}_{2}$ samples (A - top frame) from the moderate to high $\mathrm{SiO}_{2}$ samples (B -middle frame) and provides normal mid-ocean ridge basalt (NMORB), enriched mid-ocean ridge basalt (EMORB), ocean island basalt (OIB), and island arc basalt (IAB) chemistries (Sun and McDonough, 1989; Nye and Reid, 1986) for comparison (C - bottom frame). The raw geochemical data used to generate these variation diagrams is provided in the Supplementary Materials section of this document. 


\section{$\underline{\text { Rock/NMORB }}$}

The horizontal axes of Figure 26, the NMORB-normalized trace element variation diagram, lists a series of trace elements organized based on their compatibility within common mineral structures (compatibility increasing to the right). The low $\mathrm{SiO}_{2}$ samples (01DF15, 08DF15, 25DF15, 32DF15, and 38DF15; Fig 26 A) show a range of chemical trends, but all show enrichment among large ion lithophile elements (LILEs - e.g. Cs, Rb, Ba, Th) with values ranging from 30 to 110 times the concentration found in a NMORB. Some low $\mathrm{SiO}_{2}$ samples show depletion among the high field strength elements (HFSEs - e.g. Nb, P, Zr, Ti) particularly samples 01DF15, 32DF15, and 38DF15.

The high $\mathrm{SiO}_{2}$ samples (Fig. $26 \mathrm{~B}$ ) show some similar trends. All six high $\mathrm{SiO}_{2}$ samples ( 55- $63 \mathrm{wt} \% \mathrm{SiO}_{2}$ ) display a negative $\mathrm{Nb}$ anomaly, meaning the concentration of $\mathrm{Nb}$ is less than would be expected from the values of adjacent trace elements on the plot. This is accompanied by depletion among other HFSEs (Ti and Zr) in samples 03DF15, 11DF15, and 33DF15. The negative Nb anomaly is particularly prevalent in samples 03DF15, 11DF15, 13DF15, 21DF15, and 24DF15. Depletion of Rb, Nb, P, and Zr all occur within the IAB representative sample. Among the most compatible trace elements (Y, Yb, Lu), all eleven samples show nearly flat trace element patterns, similar to the patterns of NMORBs and EMORBS.

The NMORB-normalized chemistry of rocks from the Apoon assemblage show similarities to the patterns observed within island arc basalts (IABs) and mid-ocean ridge basalts (MORBs). Specifically, the high-silica Apoon Assemblage samples contains LILE enrichments and HFSE depletions similar to IAB patterns world-wide (Fig. 26; e.g 03DF15, 11DF15, 
13DF15, 21DF15, 33DF15, 25DF15). Similarly, some of the low-silica Apoon samples display similarities to MORB trends (Fig. 26; e.g. 01DF15, 08DF15, 25DF15, 32DF15, 38DF15). These are characterized by flat-lying patterns in compatible trace elements in MORB-normalized plots (e.g. Nd, Sm, Eu, Dy, Yb, Lu). No samples showed significant similarity to OIB patterns on NMORB-normalized trace element plots.

\section{$\underline{\text { Rock/Chondrite }}$}

Chondrite-normalized rare earth element (REEs) variation diagrams are a special subset of trace element variation diagrams which capitalize on the unique behavior of the Lanthanide series of elements ( $\mathrm{La}-\mathrm{Lu}$ ). Because the Lanthanides systematically decrease in atomic radius with increasing atomic number $(\mathrm{La} \rightarrow \mathrm{Lu})$, their partition coefficients and partitioning behavior in igneous systems also vary systematically. Similar to Figure 26, low $\mathrm{SiO}_{2}$ samples are plotted in the top frame (Fig. $27 \mathrm{~A}$ ) and followed by the high $\mathrm{SiO}_{2}$ samples (Fig. $27 \mathrm{~B}$ ) and representative basalt samples (the same used previously; Fig. 27 C). All composition are normalized to the composition of a normal chondritic meteorite based on the values of Sun and McDonough (1989). Light rare earth elements (LREEs) refers to La, Ce, Pr, Nd. Middle rare earth elements (MREEs) refers to Sm, Eu, Gd, Tb, Dy, and Ho. Heavy rare earth elements (HREEs) refers to Er, Tm, Tb, and Lu.

The chondrite normalized REE variation diagrams from the Apoon assemblage show a wide range of patterns. In general, the low $\mathrm{SiO}_{2}$ samples display an array of LREE enrichments. Specifically, sample 01DF15 shows a clear enrichment in LREE abundances, while sample 08DF15 shows a dramatically lower LREE abundances. The other low SiO2 samples (e.g 
25DF15, 32DF15, and 38F15) have relatively flat REE patterns with LREE to HREE (right side of Fig. 27) abundances approximately 20-30x chondrite. For example, sample 38DF15 shows near parity among the REEs, meaning the abundance of each REE is similar to the others when normalized to chondritic compositions generating a relatively flat pattern. Its pattern most closely resembles that of the EMORB, which has very mild enrichment among LREEs and approximant parity across the MREEs and HREEs.

The high $\mathrm{SiO}_{2}$ samples all show enrichment of the LREEs relative to the MREEs and HREEs. The LREEs in these samples range from 20 to 110 times the amount expected in chondritic meteorites. All high $\mathrm{SiO}_{2}$ samples show flat patterns among the HREEs, similar to the patterns of both NMORBs and EMORBs. Five samples show anomalously low concentrations of Eu as compared to its adjacent REEs (38DF15, 33DF15, 24DF15, and 13DF15), a feature commonly attributed to the fractionation of plagioclase (see Section 6; discussion). Two samples (03DF15, 11DF15) show LREE and MREE patterns which resemble the composition of OIBs, but they have considerably different HREE patterns compared to OIB. One difference is the slight positive Eu anomaly within the OIB sample, which is noticeably different from the minor negative Eu anomaly within 03DF15 and 11DF15. These samples show similarities to both OIBs and highly LREE enriched IABs. Three samples (13DF15, 21DF15, and 24DF15) show LREE and MREE patterns which most closely resemble the chemistry of IABs.

\section{$\underline{\mathrm{Ti}-\mathrm{V} \text { ratios }}$}

The Ti-V diagram of Shervais (1982) capitalizes on variation in the behavior of Ti and V as a product of differences in their partition coefficients. Because V is found in both reduced (V 
$3^{+}$) and oxidized states ( $\mathrm{V} 4+$, and $\mathrm{V} \mathrm{5+)} \mathrm{within} \mathrm{magmas} \mathrm{and} \mathrm{Ti}$ is not (only exists as $\mathrm{Ti} 4+$ ), the proportion of V:Ti can serve as a proxy for the oxygen activity and fractional crystallization processes, which took place in a magma at the time of eruption. Shervais (1982) related this to the tectonic environment of eruption. Because $\mathrm{Ti}$ and $\mathrm{V}$ are generally immobile under hydrothermal alteration and intermediate metamorphic conditions, this method allows determination of tectonic setting from ancient rocks.

Figure 28 shows the Ti - V diagram of Shervais (1982) with data from the Apoon assemblage superimposed. The gray area marks the field of data from Julian and Oldow (1998) for comparison. Samples from this study plot within the island arc tholeiite and back arc basin MORB fields, and show considerable compositional overlap with the data from Julian and Oldow (1998). Only those samples which classified as basalts and basaltic andesites were included in this figure because the complexities of more highly evolved magmas can affect the proportion of Ti and V by other means (as per Shervais, 1982).

\section{DISCUSSION}

\subsection{Field Relations and Overview}

The Apoon assemblage has been tentatively related to a volcanic arc setting for four decades based on sparse and incomplete data (Dutro et al., 1976; Mull et al., 1987; Julian, 1989; Julian and Oldow, 1998). The relative inaccessibility and complicated field relationships within the Doonerak fenster have prevented conclusive determination of the tectonic setting in which the Apoon assemblage formed. Only small portions of the fenster have been studied in any 
appreciable detail and its stratigraphic and structural architecture is complex and difficult to decipher. One goal of this research was to provide evidence to help constrain the setting in which the Apoon assemblage formed and test the possibility that rocks exposed in the Doonerak fenster are the remnant of an island arc complex, which could be related to the suture between Laurentian and non-Laurentian portions of Arctic Alaska. We also aimed to better understand the provenance of the Apoon assemblage and Ellesmerian Sequence within the fenster relative to the rocks of the Endicott Mountains allochthon and Hammond subterrane, which structurally overlie the fenster within the Brooks Range. The data presented in section 5 provides new insight into the origins of these sequences and, when placed in the context of other recent regional studies, corroborates the interpretation that the Apoon assemblage is the remnant of an island arc complex. The new data also highlights significant outstanding issues concerning the structure and stratigraphy of the Apoon assemblage and some regional relationships.

The updated geologic map and cross section of the North Fork Koyukuk River along the northern margin of the Doonerak fenster in the central Brooks Range (Fig. 5, 8 and 9) make several alterations from previous interpretations. Some notable changes include (1) treatment of the Apoon igneous sequence, Pzv, as two different units - Pzv intrusives and Pzv flows, which are mapped collectively with Pza in keeping with Strauss et al. (2017), (2) the extension of Pzp, the Apoon phyllitic unit, to the east along strike of where it was mapped by Strauss et al. (2017) in the southernmost portions of the map area, (3) the presence of an inferred thrust fault in the southern region to accommodate juxtaposition of Pzp against Pzv intrusives and Pzc, the Apoon clastics, (4) the grouping of several small discontinuous map units of Brosge and Reiser (1960, 1971) and Dillon et al., (1986) into the Beaucoup Formation along the northern margin of the fenster in the hanging wall of the Awawk thrust, (5) the differentiation of the Kayak and 
Lisburne Formations along the southern banks of the North Fork Koyukuk, and (6) extension of the Hunt Fork - Endicott Group contact south of Shushalluk Creek in the northwest portion of the map area based on recognition of the Noatak and Kanayuk formations in that location.

Data from six samples of sandstone analyzed for detrital zircon geochronology from the vicinity of the North Fork Koyukuk River in the Gates of the Arctic National Park are summarized in Figure 29. Placing this data into context requires consideration of potential source regions, which may have contributed primary igneous and metamorphic zircon grains as detritus and potential sources of recycled detrital grains. Detrital spectra from particular regional map units allows for comparison to data from the same formations elsewhere and comparison to regionally associated units from elsewhere in the circum-Arctic. Unpublished detrital geochronologic data from elsewhere in the central Brooks Range was provided by E. L. Miller (Stanford) and V. Pease (U. of Stockholm) for comparison to relatively proximal portions of the Brooks Range (Fig. 30). These data come from the John River, an area also within the Gates of the Arctic National Park, but about 50 km west of the North Fork Koyukuk River. The John River transect samples include some of the same stratigraphy, the Beaucoup and Hunt Fork formations, but come from the Endicott Mountains allochthon and Hammond subterrane and also contain the Sillyasheen formation of the Hammond subterrane. Other detrital zircon data from the Apoon assemblage, Ellesmerian Sequence, and Trembly Creek phyllite (Fig. 31) allow for direct comparison of map units in the vicinity of the North Fork Koyukuk, within the Doonerak fenster from Strauss et al. (2017). These provide the most direct comparison to associated strata from within and near the Doonerak fenster. Lastly, a suite of detrital spectra from elsewhere in the Arctic (Fig. 32; NE Brooks Range, Canadian Arctic, and Svalbard) allow for comparison of regional trends in provenance. 


\subsection{The Beaucoup and Hunt Fork Formations: Hanging wall of the Awawk Thrust}

The Beaucoup Formation and Hunt Fork Shale are widespread Late Devonian units of conglomerate, shale, slate, sandstone, and siltstone that are ubiquitous across much of the Brooks Range (e.g. Tailleur et al., 1967; Dutro et al., 1979; Moore et al., 1994). Their heterogeneity in terms of lithostratigraphy and provenance, although recognized, is poorly defined. Along the northern margin of the Doonerak fenster near the North Fork Koyukuk River, discontinuous units of sandstone, sheared green-purple conglomerate, wacke, shale, and slate have been assigned to both of these units by previous mappers (Dillon et al., 1986; Brosge and Reiser, 1961 and 1971). Herein, we define the contact where the fissile gray-tan shales/slates of the Hunt Fork become the dominant lithology (Fig. 8). This ascribes the complicated package of interbedded and folded conglomerates, wacke and sandstones to the Beaucoup Formation. What is herein defined as the Beaucoup also includes the well-foliated, sheared green-purple quartz and chert pebble conglomerate found near the confluence of the North Fork Koyukuk River and Ernie Creek (Fig. 8 and 16; previous section).

Some previous workers have also suggested that these units along the northern margin of the Doonerak fenster might fit better into formations of the Hammond Terrane particularly the Trembley Creek phyllite, which is recognized along the southern margin of the fenster (Strauss et al., 2017) and could have continuity to its northern side; however that assertion is not well borne out in the new data. Samples 43DF15 and J1415 both come from this complicated border zone in the hanging wall of the Amawk thrust. Sample J1415 is a sheared green-purple conglomerate definitively from the Beaucoup Formation; however, 43DF15 was a dark lithic 
sandstone found in close proximity to the thinly bedded brown slates of the Hunt Fork Shale. In the field 43DF15 could arguably be assigned to either the Hunt Fork or the Beaucoup although it is most similar to the Beaucoup Formation. This ambiguity complicates interpretation of its unique detrital zircon spectrum (Fig. 31 and 21), which bears similarities to the other Beaucoup sample (J1415) and the Hunt Fork sample (26DF15); however, it is largely dissimilar to the Trembley Creek phyllite (Fig. 5) sample from Strauss et al. (2017), which completely lacks the otherwise prominent 440 Ma centered population in the other samples and has a greater abundance of 800 - 550 Ma zircons and other Precambrian populations.

Comparing these detrital zircon spectra highlights several similarities and differences between various formations. In regard to the calculated maximum depositional ages, none of these three formations produce anomalously young maximum depositional ages; however, it is curious that the youngest detritus within 26DF15 (Hunt Fork; Fig 22) is actually older than the youngest detritus within J1415 (Beaucoup; Fig. 20) because the Beaucoup is stratigraphically below the Hunt Fork (see Fig. 5). Both produce Late Devonian maximum depositional ages which fall within error of each other and are in concert with the stratigraphic age of both these formations. The fact that their maximum depositional ages fall within error of each other, prevents any major claims based solely on this; however, sample 43DF15 generates a maximum depositional age of 397.1 \pm 6.4 Ma (Early Devonian) and therefore has a distinct detrital signature, and could be older than both J1415 and 26DF15. It is important to state explicitly that this does not necessarily mean 43DF15 is Early Devonian in depositional age, just that the youngest detrital zircon it contains are Early Devonian. It could still have been deposited in the Late Devonian, consistent with the Beaucoup stratigraphic age. 43DF15 also contains a minor 
peak at $506 \mathrm{Ma}$, similar to one seen within J1415 (Beaucoup Formation), which is the same age as the dominant unimodal peak within sample 05DF15 (Apoon assemblage).

When considered relative to the Hunt Fork, Sillyasheen, and Beaucoup Formations of the John River transect (Fig. 30), sample 43DF15 bears similarities to all three, but more closely resembles the Beaucoup Formation than the Hunk Fork Shale based on the position of its prominent Caledonian population and the presence of some 800 - 550 Ma (Timanian) zircons. Ultimately the detrital spectra and lithologic characteristics of 43DF15 are more similar to the Beaucoup Formation, and it is therefore included within the Beaucoup Formation rather than the Hunt Fork Shale.

It is important to note another significant aspect of 43DF15, which makes it similar to the Trembley Creek phyllite in some respects. Figure 31 compares the samples of this study to those from Strauss et al. (2017). Strauss et al. (2017) analyzed one sample from the Trembley Creek phyllite of the Hammond subterrane from the southern margin of the Doonerak fenster. Interestingly, this sample contained a prominent population centered on $504 \mathrm{Ma}$, the exact same age as the major population found in 05DF15 (Apoon Assemblage). The Trembley Creek phyllite sample also contains a significant population centered on 635 Ma, a Timanian age, and accessory populations consistent with various Proterozoic detritus common to Laurentian rocks. Notice that sample 43DF15 contains a distinct population of 550 - 800 Ma zircon, which is also present within the Trembley Creek phyllite and is rare among other samples (Fig. 31; some rare grains of this age are present within the Endicott Group of this study and of Strauss et al., 2017). Detrital spectra of that age could be the result of detritus from the Timanian orogen of northern Baltica (see Fig. 2). This indicates that both 43DF15 (Beaucoup) and the Trembley Creek phyllite likely received some portion of their detritus from the Timanian orogen. 
That said, the dominant population within 43DF15, a Caledonian age peak centered on $420 \mathrm{Ma}$, contains the vast majority of zircon from that sample. The complete lack of this population within the Trembley Creek phyllite indicates that these cannot possibly be from the same formation. While they may both contain some Timanian detritus, they are not from the same formation. The detrital zircon spectrum of sample 43DF15 is most similar to the Beaucoup Formation (see section 6.3 and 7 for more on the relationship to the Trembley Creek sample and the Timanian orogeny).

\subsection{The Apoon Assemblage and the Endicott Group}

Sample 05DF15 was collected from the volcaniclastic portion of the Apoon assemblage (Pzc of Julian and Oldow, 1998) south of Pyramid Creek and contains a dominantly unimodal detrital zircon spectrum (Fig. 18). A prominent peak centered on 504 Ma (Cambrian) contains $\sim 75 \%$ of the zircon analyzed from this sample. The youngest grains from 05DF15 generate a maximum depositional age of $452 \pm 13$ Ma (Ordovician). Detrital populations of this same age appear as minor constituents in several other samples, J1415 and 43DF15, potentially indicating that minor amounts of Apoon detritus were recycled into the Beaucoup Formation or that the Beaucoup Formation received some portion of its detritus from the same regions as the Apoon itself.

Several interesting characteristics emerge when 05DF15 (Apoon; Fig 18) is compared to the detrital samples of Strauss et al. (2017) (Fig. 31). First, none of the Apoon samples from their study contain the same unimodal population (504 Ma centered population). Instead, their samples contain prominent peaks centered on 440 Ma, 475 Ma, 483 Ma, or 493 Ma. Their 
aggregated Apoon Assemblage spectrum (Fig. 31 - B) has a prominent peak centered on 480 Ma, noticeably younger than 05DF15's major population at $504 \mathrm{Ma}$. The samples they collected from the Apoon Assemblage Pzc unit, approximately along strike 05DF15, contain the same minor accessory peaks as 05DF15; however, they lack the 504 Ma population and instead contain younger (Ordovician-Silurian) major populations. One sample contained major populations both younger and older than that observed in 05DF15 (475 Ma and $540 \mathrm{Ma}$ ), but it still lacked detritus similar in age to the 504 Ma peak. Within the Apoon Assemblage phyllitic unit, Pzp, they recorded two samples. One contained a 440 Ma population and a complete lack of other detritus. The second contained a dominant population centered on $493 \mathrm{Ma}$ ( $\sim 80 \%$ of the sample) with minor populations at 570 Ma and 429 Ma.

When 05DF15 is considered in conjunction with all the samples from Strauss et al. (2017), the nomenclature of Julian and Oldow (1998) is brought into question. While their subdivisions of the Apoon assemblage are useful inasmuch as they provide helpful lithostratigraphic divisions of the broader succession, they cannot be clearly defined in terms of their age relationships. Julian and Oldow (1998) acknowledged that these units could overlap in age, but this results in the grouping of units in the field, which vary in age by up to 50 my and potentially over simplifies complex relationships. Despite their shortcomings, these subdivisions remain the most useful and practical subdivisions of the Apoon assemblage currently available and Figure 8 carries this nomenclature into the north-central portion of the fenster, in keeping with Strauss et al. (2017) to the east. This study only analyzed the detrital spectrum from one Apoon sample, 05DF15. Strauss et al. (2017) analyzed only five. The spectra of 05DF15 is markedly different from any of those five samples. This highlights the significant shortcomings in our current divisions of the Apoon assemblage. The full diversity of Apoon clastics has not 
been sufficiently described. Future work should focus on analyzing a broader suite of Apoon siliciclastics to better define the range of ages present and to provide more useful subdivisions. As it currently stands, multiple non-age-equivalent map units are likely grouped together, misrepresenting the complexities of the Apoon Assemblage in both structure and stratigraphy.

Finally, apart from a greater abundance of Grenville and other Proterozoic detritus, the Endicott Group spectra of Strauss et al. (2017) are very similar to the Kayak and Kanayut curves from samples 23DF15 and 41DF15 respectively (Fig. 31 - A). Strauss et al. (2017) only sampled the Endicott Group within the Doonerak fenster. The similarity to sample 41DF15, which comes from the Endicott Group (Kanayut Formation) of the Endicott Mountains allochthon, implies that by the time these units were deposited (Mississippian) the Endicott Group of the Doonerak fenster and the Endicott Group of the Endicott Mountains allochthon were receiving detritus from similar areas. Recall that the rocks of the Endicott Mountains allochthon did not achieve their current structural position, in fault contact above the rocks of the Doonerak fenster, until the Mesozoic Brookian orogeny. Therefore, by Mississippian time rocks of the Endicott Mountains allochthon and those unconformably atop the Apoon assemblage were likely being deposited in the same broad system, prior to emplacement of the Endicott Mountains allochthon.

\subsection{Circum-Arctic Comparisons and Paleotectonic Setting of the Apoon Assemblage}

Understanding the similarities and differences between the detrital zircon spectra of rocks of the Doonerak fenster relative to other rocks in the Brooks Range is important for correlation of widely distributed map units. It does little, however, to help elucidate connections to other regions of the circum Arctic, which is necessary to inform paleogeographic models. Figure 33 
illustrates two possible paleogeographic reconstructions of circum-Arctic terranes during the late Ordovician ( 450 Ma), at the approximate time of deposition of the Apoon siliciclastics (sample 05DF15 maximum depositional age $452 \pm 13 \mathrm{Ma}$ ). Two lines of evidence from this study can be used to evaluate such models and potentially help discriminate between them: (1) the comparison of detrital spectra to regional sediment sources and (2) the use of the whole rock geochemical data to help determine the paleotectonic setting in which the Apoon assemblage formed.

Limited evidence has been used to suggest that the Apoon assemblage formed in an arc setting for several decades (see section 3), but the data was inconclusive and did not provide exclusive determination of the Apoon's paleotectonic setting (e.g. Julian and Oldow, 1998). The new whole rock geochemical data herein provides an independent line of evidence to help determine the tectonic setting in which the Apoon Assemblage volcanics formed and can be compared to previous work to either corroborate or refute the assertion that the package formed as part of an island arc. Recall that at least some of the Apoon igneous rocks were dated to between $520 \pm 17$ Ma and $373 \pm 17$ Ma by K-Ar and Ar-Ar analysis of hornblende in mafic dikes crosscutting the Pzc unit (Dutro et al., 1976), therefore the reconstructions of Figure 33 represent a time when the Apoon volcanic units were still likely forming. Therefore the geochemistry of these volcanic units can be used to assess the validity of these paleogeographic reconstructions.

Trace element geochemistry is only useful for determining the tectonic environment in which a rock formed if we make some assumptions about the geological processes which control the distribution of trace elements in different tectonic settings. Some such processes are well understood and their effects on trace element distribution in magmas is well defined; however, the inherently incomplete nature of our understanding of chemical behavior of magmas 
introduces uncertainty into deciphering the geological processes capable of generating any given trace element distribution. That said, several fundamental processes must be considered to determine which trace elements and trace element ratios provide the most reliable information about the environment in which an igneous rock formed. All rocks exposed to hydrothermal and metamorphic conditions have experienced some amount of element mobility. As such, high field strength elements (HFSEs), such as, Zr, Hf, Ti, Nb, Ta, and P (Pearce, 1983) which are immobile up to moderate metamorphic conditions are more reliable than their low field strength counterparts. Other elements are also commonly immobile (Co, $\mathrm{Ni}, \mathrm{V}$ and $\mathrm{Cr}$ ), but the degree of mobility of all elements is complicated by particular mineral phases capable of incorporating them and various fluid controls (Humphries, 1984). A special case of element mobility occurs in subduction zones, where dehydration of the subducted oceanic slab causes metasomatic reactions which mobilize some elements ( $\mathrm{Sr}, \mathrm{K}, \mathrm{Rb}, \mathrm{Ba}$, Th, Ce, P, and $\mathrm{Sm}$ ) which may be immobile under other conditions (Pearce, 1983; Tatsumi, 2005). This affects the composition of both the magma expelled from arc volcanoes, derived from the overlying mantle wedge, and the residual components of the slab. In terms of this study, which provides relatively little complementary evidence to understand how particular volcanic rocks are related to each other in the field, it is difficult to know if different samples are part of the same cogenetic suite or if they come from different sources entirely. Regardless, we must consider the affect any petrological process would have on the trace element distribution of both a partial melt and a residual solid.

The major element geochemistry of all rocks analyzed from the Apoon assemblage characterize them as part of the sub-alkaline series and define them as various basalts, basalticandesites, andesites, and minor trachyandesites based on their proportions of silica to total alkalis $\left(\mathrm{SiO}_{2}\right.$ to $\left.\mathrm{Na}_{2} \mathrm{O}+\mathrm{K}_{2} \mathrm{O}\right)$ after Le Maitre et al. (2002). While this simple classification helps 
illustrate the range of rock types present, it does not help assign them to a particular tectonic environment, because basalts and andesites are common to multiple tectonic settings.

The NMORB normalized trace element diagrams (Fig. 26) highlight enrichment in highly incompatible trace elements, especially in the samples with the greatest abundance of $\mathrm{SiO}_{2}$. Large ion lithophile elements (LILEs; e.g. Cs, Rb, Ba, Th) are enriched to between 50 and 1000 times the composition of a NMORB in the high $\mathrm{SiO}_{2}$ samples. Those same elements are enriched, but to a lesser extent, in the low $\mathrm{SiO}_{2}$ samples. Nearly all samples show depletion among HFSEs (e.g. Nb, P, Zr, and Ti), especially in Nb. Such depletion in HFSEs is characteristic of magmas from arc settings because HFSEs can be left within the down-going slab as other trace elements are liberated during dehydration and incorporated into the overlying mantle wedge, ultimately being incorporated into the magma of arc volcanoes (e.g. Tatsumi, 2005). Conversely, the patterns of the most compatible trace elements (e.g. Y, Yb, Lu) are similar to normal and enriched MORBs across all samples (flat lying patterns to the right side of Fig. 26).

On the whole, the Apoon Assemblage volcanic rocks cover a wide range of REE geochemical trends, even among samples with similar $\mathrm{SiO}_{2}$ abundances, which classify as the same rock type based on their total alkali-silica compositions (Fig. 24). Samples 01DF15 and 08DF15 both classify as basalts based on their total alkali-silica abundances and come from relatively proximal locations within the field area south of Pyramid Creek (Fig. 8). Despite these similarities, these samples (01DF15 and 08DF15) have entirely different REE patterns (Fig. 27 A). 08DF15 is depleted in the LREEs relative to the MREEs and HREEs, while 01DF15 is enriched in the LREEs relative to the MREEs and HREEs. These two samples are indistinguishable in terms of their textures, basic minerology, and major element compositions, 
so these REE differences cannot be explained as a product of differences in rock type. Such variation in REE trends among otherwise similar rocks could be explained by small degrees of partial melting, which would preferentially liberate LREEs into the melt phase. Ultimately this could result in the residue and the melt phase forming two different rocks with mirrored REE patterns, as seen in 01DF15 and 08DF15. That said, because there is no age constraint on either of these samples and their field relationships are ambiguous it is not possible to determine if these two samples are in fact genetically related. The same geochemical trends could result from the melting of two different initial sources.

The high SiO2 samples (Fig. 27 - B) are all highly enriched in LREEs (03DF15, 11DF15, and 33DF15) relative to the MREEs and HREEs, ranging from 20 to 110 times the composition of a normal chondrite. Samples 03DF15 and 11DF15 (Fig. 27 - B) have geochemical trends and relative abundances of LREEs, MREEs, and HREEs that most closely resemble the ocean-island basalt (OIB) representative sample (Fig. 27 - C). Other high $\mathrm{SiO}_{2}$ samples demonstrate some direct similarities to island arc volcanic rocks (IAB representative basalt in Fig. 27 - C) especially among the LREEs and MREEs in samples 13DF15, 21DF15, and 24DF15 (Fig. 27 B).

Eight of the eleven samples also show a negative Eu anomaly - depletion of Eu relative to its adjacent REEs (Sm and Gd). Europium anomalies are controlled by the precipitation of feldspars from the melt because divalent Eu is easily incorporated into plagioclase, whereas other REEs (trivalent) are incompatible within the structure of feldspars. A melt can attain a negative Eu anomaly, as seen in many Apoon igneous samples, by the removal of feldspar by fractional crystallization or by the partial melting of a rock in which feldspar, laden with Eu, is retained in the source. At least one sample (25DF15) has a positive (rather than a negative) Eu anomaly, 
which could result from the exact opposite scenario, if that sample were derived from a rock with abundant feldspar laden with Eu. As before, without age constraints and better defined field relationships it is not possible to confidently know if these samples are genetically related, but it is at least conceivable that 25DF15 (positive Eu anomaly) represents the residue from which the other samples (with negative Eu anomalies) might have been derived by partial melting. This further highlights the great range in REE geochemical trends found within igneous rocks of the Apoon Assemblage and suggests that the tectonic setting in which these rocks formed must be capable of producing a sufficiently wide range of geochemical trends. As a general rule, volcanic arcs and subduction zones are more capable of producing such a wide range in trace and REE trends than other tectonic settings (e.g. Bacon et al., 1997; Tatsumi, 2005).

Another high $\mathrm{SiO}_{2}$ sample, 33DF15 (Fig. 27 - B), is also best explained through formation in an arc setting. Although 33DF15 has an overall higher REE pattern, meaning all REE occur in greater abundances than in the other samples, this could be explained by very small partial melts or considerable amounts of fractional crystallization. The overall shape of 33DF15's REE pattern is still consistent with that of the island arc basalt (IAB; Fig. 27 - C) representative sample, potentially indicating a wet and oxidized setting where plagioclase is not strongly crystallized (small Eu anomaly).

The depletions in high field strength elements (HFSEs) observed within the NMORB normalized diagram also suggests formation within an island arc setting. HFSEs are often retained within particular mineral structures and often not incorporated into the overlying mantel wedge along subductions zones, leading to a relative lack of some HFSEs in the magma of arc volcanoes as compared to the abundance of other trace elements. Niobium (Nb) is particularly useful in this regard because its abundance is not often controlled by the presence of any 
particular mineral phase that might preferentially incorporate it, so if $\mathrm{Nb}$ is depleted relative to other trace elements it is best explained by formation in a subduction zone related tectonic setting, where $\mathrm{Nb}$ can be sequestered within the down going slab. Highly prevalent negative $\mathrm{Nb}$ anomalies occur within eight of the eleven samples analyzed from the Apoon Assemblage, further suggesting formation within an island arc tectonic setting.

Placing this information into context alongside the Ti:V ratios of the Apoon samples (Fig. 28) begins to highlight the strong likelihood that the igneous portions of the Apoon assemblage are likely derived from a subduction-related tectonic setting. Fig. 28 suggests formation within either an arc setting or a mixed back arc basin setting based on the proportion of Ti:V within these rocks, which occurs as a result of the oxygen activity and fractional crystallization processes within a magma chamber (Shervais, 1982). This in conjunction with the trace and REE data, further corroborates the formation of the Apoon in an arc setting.

It remains difficult to differentiate between the potential of either an island arc or a continental arc based on these chemical trends alone; however, the clean unimodal detrital zircon populations from Apoon Assemblage sample 05DF15 indicates that most detritus was contributed from a proximal source and that only a minor proportion came from some continental margin. This supports the idea that these rocks formed, at least initially, in a relatively isolated paleogeographic setting, which is more consistent with an island arc rather than a continental one. Additionally, some features within the Apoon rocks indicate subaqueous extrusion of magma during their formation (pillow basalts along Bombardment Creek; Fig. 15). This potential arc system could have been influenced by dry asthenosphere magmas, which could help form the MORB like geochemical trends, or by the subduction of non-typical oceanic crust (e.g. an ocean island or seamount), which could result in some of the ocean-island basalt like 
geochemical trends. Those complexities cannot be determined from this data alone, but the diversity among the trace and rare earth elements seen within the Apoon assemblage is best explained by its formation within an island arc setting.

Other geochemical and isotopic evidence corroborates an island arc interpretation for the oridin of the Apoon Assemblage. Strauss et al. (2017) conducted U-Pb analysis on a set of igneous zircon from a leucogabbro within the Apoon assemblage in order to corroborate previous dating of the volcanic units (Fig. 6). The age Strauss et al. (2017) found fell within the range of previously published ages (462 \pm 8 Ma; Ordovician); however they also conducted Hf isotopic analysis on the zircon grains and calculated highly positive $\varepsilon \mathrm{Hf}$ values $(\varepsilon \mathrm{Hf}=+13)$, which suggest a distinct lack of crustal assimilation and corroborate the idea of these rocks having formed in an island arc setting. This strongly suggests that the rocks of the Apoon Assemblage had limited crustal influence, at least from ancient continental crust. Additionally, they found similar $\varepsilon$ Hf values within their Ordovician age detrital populations from the Apoon Pzc unit. Again, this suggests that these clastics were receiving detritus from a highly juvenile source. Collectively, this data and the geochemical data presented herein indicate conclusively that the Apoon assemblage formed as part of an island arc complex, which could have persisted for tens of millions of years based on the range of depositional ages found from the Apoon assemblage, but more data is needed to fully address that.

We have demonstrated that sample 05DF15 contains a prominent unimodal detrital zircon population centered on 504 Ma (Cambrian; Fig. 29) and has a maximum depositional age of $452 \pm 13$ Ma (Ordovician). Strauss et al. (2017) demonstrated that detrital spectra from other samples of the Apoon assemblage contain prominent youngest peaks centered on $\sim 475 \mathrm{Ma}, 478$, 483, 429, and $440 \mathrm{Ma}$ (Fig. 31). This alone indicates that the Apoon assemblage was deposited 
within a long lived depocenter, which must have persisted for 40 - 50 my. Apoon samples from Strauss et al. (2017) contain diagnostic accessory peaks (980 - 1200 Ma; 1300 -1500 Ma, 1600 $1800 \mathrm{Ma}, 2600$ - $2800 \mathrm{Ma}$ ) that are suggestive of detritus from the Laurentian margin (Grenville, Pinwarian, Superior craton, ect.).

Additionally, a sample of the overlying Kayak Formation (23DF15) from this study and the Endicott Group of Strauss et al. (2017) contain prominent Caledonian age peaks centered on 420 Ma (Fig. 31). Recall that sample 43DF15 (max depositional age 397.1 \pm 6.4 Ma), which was assigned to the Beaucoup Formation, contains a prominent unimodal Caledonian age peak and significant amounts of Timanian age detritus (Fig. 21). This means that between the time of deposition of the youngest Apoon sample known ( 420 Ma max depositional age; J1427 of Strauss et al. (2017)) and deposition of sample 43DF15 sedimentary provenance changed in several ways. There was an increase in the amount of Timanian detritus and the appearance of Caledonian age spectra all alongside typical Laurenitan spectra (Grenville, ect.). This change in provenance occurred between the deposition of these units; however, because the Beaucoup sample (43DF15) could have been transported a great distance during Brookian thrusting it is difficult to know how to fit this into a paleogeographic context.

Elsewhere in the Arctic, along the Varanger Peninsula (Fig. 1 and 2) of the northern Baltic states, Caledonian and Timaninan rocks are sutured together (e.g. Gee and Pease, 2004 and references therein). The coexistence of Timanian and Caledonian age detritus within 43DF15 (Beaucoup Formation), indicates that there may be continuity of this suture on the Alaskan side of the Arctic.

Caledonian age (Laurentian side) and Timanian age (Russian side) detritus is similarly ubiquitous across much, though not all, of the circum-Arctic and allows for comparison to the 
units from this study (Fig. 33). Zircon between 990 - 820 Ma from the Clarence River Group of the NE Brooks Range (Johnson et al., 2016) are mostly absent from samples collected along the North Fork of the Koyukuk River except for minimal sporadic grains. Tentative links between rocks of Doonerak and those of the northeast Brooks Range have been discussed for several decades (e.g. Moore, 1987; Moore et al., 1994; 1997) because broadly coeval mafic volcanic rocks of the Whale Mountain area (Fig. 1 and 2) have similar chemistry to those at Doonerak (Moore, 1987) and are similarly enigmatic. Zircon of this 990 - 820 Ma range are not common however, and are thought to be related to the collapse of the Grenville orogen, related to rocks in the Central Gneiss Belt of Ontario, CA (Ketchum et al., 1998), the East Greenland Caledonides (Kalsbeek et al., 2000; Watt et al., 2000), the Canadian Arctic and Svalbard. The presence of these in the northeast Brooks Range and general lack of them in the Apoon samples (and others) at Doonerak suggests differences in the sediment pathways between Doonerak and the Whale Mountain area (Fig. 1 and 2).

Early Neoproterozoic (1000 - $541 \mathrm{Ma}$ ) magmatic rocks have also contributed detritus to the peri-Laurentian terranes of the Canadian Arctic and Greenland, including Pearya (e.g. Trettin, 1987) and Svalbard (e.g. Gee et al., 1995; Johnansson et al., 2004, 2005). Connections between Pearya, Svalbard and possibly the northeast Brooks Range are apparent (Fig 33), but the same cannot be said for the Apoon assemblage rocks of Doonerak. The prominent peak of the Apoon sample (05DF15) is slightly older than those associated with most other locales and generally lacks the accessory peaks which draw links to Svalbard, Pearya, and the Clements Markham Belt of Ellesmere Island (Canadian Arctic) (See Fig 1. for locations). This implies that while 05DF15 was being deposited (452 $\pm 13 \mathrm{Ma}$ ) there were only limited similarities in the sediment pathways between these landmasses. That said 05DF15 does contain some older 
accessory peaks which link it to the Laurentian margin to some degree. Yet, the age of 05DF15's major peak (504 Ma) is rare among Laurentian rocks. Regarding the paleogeographic implications, there is admittedly limited data to support or refute either model proposed in Figure 33; however, the general dissimilarities between the detrital spectra of the Apoon as compared to those of Pearya, Ellesmere Island, northwest Svalbard, and southwest Svalbard more closely support Model A “Peri-Baltica” over Model B “Peri-Laurentian.”

The unimodal Apoon sample from this study (05DF15) suggests that a geographically isolated island arc existed during the Cambrian and generated significant amounts of detritus, which was deposited to form some of the older Apoon siliciclastics. The increasing proportion of Laurentian affinity detritus within younger Apoon samples from Strauss et al. (2017; Fig. 31) indicates that this arc progressively approached the continental margin of Laurentia. All of the Devonian and Mississippian age rocks from this study (Beaucoup Fm., Hunt Fork Shale, Kayak Shale, Kanayut Conglomerate) contain prominent, generally unimodal, Caledonian age peaks within their detrital zircon spectra, which is evidence for an accretionary event. Some samples from this study, including the younger Mississippian age rocks (Kayak Shale, Kanayut Conglomerate), contain both Caledonian and Timanian detritus (both sides of the orogen) and likely reflect a post accretionary overlap assemblage. The Trembley Creek phyllite sample of Strauss et al. (2017) mostly lacks the Caledonian age peak, which could be explained by derivation from the passive margin side of this orogen.

\section{CONCLUSIONS}

This study aimed to provide evidence which would place the Doonerak fenster into greater context. One goal was to determine the tectonic setting in which the Apoon assemblage 
of the Doonerak fenster formed. Whole rock volcanic geochemistry, including trace and rare earth elements, was applied to igneous rocks of the Apoon assemblage and provides clear evidence for formation within a subduction zone related tectonic setting, likely an island arc. Another goal of this study was to constrain the sedimentological links between rocks of the Doonerak fenster and the Endicott Mountains allochton. Detrital zircon geochronology was applied to the Apoon Assemblage and Kayak Formation within the Doonerak fenster and to the Endicott Group of the Endicott Mountains allochthon. These data highlighted a major change in provenance from the Apoon assemblage (05DF15) to the overlying Carboniferous rocks of the Ellesmerian Sequence and showed the coexistence of detritus from the Caledonian (Laurentian) and Timanian (Baltican) orogens. Together these data help constrain the origins of the Apoon assemblage and highlight the Doonerak fenster as a probable location for the boundary between Laurentian and non-Laurentian rocks within Arctic Alaska. Several new conclusions (below) can be drawn from these data:

- The Apoon assemblage likely formed along a subduction zone as part of an island arc complex. HFSE depletions and enrichment among LREEs and MREEs suggest formation along an island arc. Although there is a considerable amount of geochemical variability within the Apoon Assemblage, many of the analyzed rocks contain chemistries similar to patterns observed within IAB and MORB world-wide. An arc interpretation is also supported by the Hf isotopic data of Strauss et al. (2017).

- Caledonian age detritus was the dominant source of clastic material for all units except the Apoon assemblage, suggesting that the Doonerak arc initially formed in a different and relatively isolated paleogeographic setting, fed by a proximal arc. The near complete 
lack of detritus from other sources (i.e. minimal presence of zircon from other populations; general lack of Grenville and other Laurentian sources) within 05DF15 indicates it formed in this isolated setting, where most detritus feeding 05DF15 was proximal. This change in provenance among the overlying units is evidence for an accretionary event which occurred between the time of deposition for sample 05DF15 (Apoon; $452 \pm 13 \mathrm{Ma}$ ) and the other clastic samples of this study, all of which contain 420 Ma centered populations (Caledonian detritus).

- The Apoon volcaniclastics were deposited in a long lived (50 my +) depocenter based on the range of depositional ages from the Apoon assemblage.

- Portions of the Apoon assemblage received detritus from similar source regions as the Beaucoup Formation and Trembley Creek phyllite, both of which contain a 504 Ma peak, identical to the dominant peak in the Apoon assemblage. The Cambrian detritus of the Endicott Mountains allochthon and Hammond subterrane could be recycled from the Apoon Assemblage.

- Similarities between the detrital spectra of the Endicott Group interior and exterior to the fenster indicate shared provenance for the Endicott Mountains allochthon and Doonerak regions by Mississippian time.

- The presence of Timanian age detritus (800 - $550 \mathrm{Ma}$; Baltican) alongside Caledonia detritus ( 420 Ma; Laurentian) in some samples (e.g. 43DF15) indicates the juxtaposition of Timanian (Baltican) and Caledonian (Laurentian) source regions in Arctic Alaska by late Devonian to Mississippian time. This likely represents a post accretionary assemblage, deposited after the amalgamation Laurentian and nonLaurentian terranes. 
- Cumulative detrital zircon spectra indicate significant dissimilarities between rocks of the Apoon assemblage and those of the Canadian Arctic and Svalbard during deposition of sample 05DF15 (Apoon), further supporting the idea that this sample was deposited in an isolated paleogeographic setting (Max Depositional Age $=452 \pm 13 \mathrm{Ma}$ ).

- Based on the data presented here, the Apoon Assemblage likely initially formed in an isolated island arc setting. This arc progressively approached and eventually docked onto the northwest margin of Laurentian in the early Paleozoic, juxtaposing Laurentian and non-Laurentian terranes within Arctic Alaska. Accretion was complete by late Devonianto-Mississippian time leading to post assembly overlap assemblages containing both Caledonian (Laurentian) and Timanian (Baltican) age detritus, which reflect both sides of the orogen. 


\section{REFERENCES}

Akinin, V.V., Gottlieb, E.S., Miller, E.L., Polsunenkov, G.O., Stolbov, N.M., and Sobolev, N.N., 2015, Age and composition of basement beneath the De Long archipelago, Arctic Russia, based on zircon $\mathrm{U}-\mathrm{Pb}$ geochronology and $\mathrm{O}-\mathrm{Hf}$ isotopic systematics from crustal xenoliths in basalts of Zhokhov Island: Arktos, v. 1. p. 9

Amato, J.M., Toro, J., Miller, E.L., Gehrels, G.E., Farmer, G.L., Gottlieb, E.S., and Till, A.B., 2009, Late Proterozoic-Paleozoic evolution of the Arctic Alaska-Chukotka terrane based on U-Pb igneous and detrital zircon ages: Implications for Neoproterozoic paleogeographic reconstructions: Geological Society of America Bulletin, v. 121, p. 1219-1235.

Amato, J.M., Aleinikoff, J.N., Akinin, V.V., McClelland, W.C., and Toro, J., 2014, Age, chemistry, and correlations of Neoproterozoic -Devonian igneous rocks of the Arctic Alaska-Chukotka terrane: An overview with new U-Pb ages, in Dumoulin, J.A., and Till, A.B., eds., Reconstruction of a Late Proterozoic to Devonian Continental Margin Sequence, Northern Alaska: Its Paleogeographic Significance and Contained Base-Metal Sulfide Deposits: Geological Society of America Special Paper, v. 506, p. 29-57, doi: 10.1130/2014.2506(02).

Anderson, A.V., Wallace, W.K., and Mull, C.G., 1994, Depositional record of a major tectonic transition in northern Alaska: Middle Devonian to Mississippian rift-basin margin deposits, upper Kongakut River region, eastern Brooks Range, Alaska, in Thurston, D.K., and Fujita, K., eds., 1992 Proceedings of the International Conference on Arctic Margins: Anchorage, Alaska, U.S. Department of the Interior, Minerals Management Service, p. 71-76.

Anderson, A.V., and Wallace, W.K., 1991, Middle Devonian to Early Mississippian stratigraphic record of the formation of a passive continental margin in northeastern Alaska: Geological Society of America Abstracts with Programs, v.23. No. 5, p. 436.

Armstrong, A.K., Mamet, B.L., Brosgé, W.P., and Reiser, H.N., 1976, Carboniferous section and unconformity at Mount Doonerak, Brooks Range, northern Alaska: American Association of Petroleum Geologists, v. 60, p. 962-972.

Bacon, C. R., Bruggman, P. E., Christiansen, R. L., Clynne, M. A., Donnelly-Nolan, J. M., \& Hildret, W., 1997. Primitive magmas at five Cascades volcanic fields: Melts from hot, heterogeneous sub-arc mantle. Canadian Mineralogist, v. 35, p. 397-424.

Barker, F., Jones, D. L., Budahn, J. R., and Coney, P. J., 1988. Ocean plateau-seamount origin of basaltic rocks, Angayuchaln terrane, central Alaska, J. Geol., v. 96, p. 368-374.

Beranek, L.P., van Staal, C.R., McClelland, W.C., Israel, S.A., and Mihalynuk, M.G., 2013a, Baltican crustal provenance for Cambrian-Ordovician sandstones of the northern Alexander terrane, Saint Elias Mountains, northwestern Canada: The Journal of Geology, v. 120, p. 293-314. 
Beranek, L.P., van Staal, C.R., McClelland, W.C., Israel, S.A., and Mihalynuk, M.G., 2013b, Detrital zircon Hf isotopic compositions indicate a northern Caledonian connection for the Alexander terrane: Lithosphere, v. 5, no. 2, p. 163-168.

Blodgett, R.B., Rohr, D.M., and Boucot, A.J., 2002, Paleozoic links among some Alaskan accreted terranes and Siberia based on megafossils, in Miller, E.L., Grantz, A., and Klemperer, S.L., eds., Tectonic evolution of the Bering Shelf-Chukchi Sea-Arctic Margin and Adjacent Landmasses: Geological Society of America Special Paper 360, p. 273-290.

Blundy, J., \& Wood, B. 1994. Prediction of crystal-melt partition coefficients from elastic moduli. Nature, v. 372 no. 6505, p. 452-454.

Brosgé, W.P. and Reiser, H.N., 1971, Preliminary bedrock geologic map, Wiseman and eastern Survey Pass Quadrangles, Alaska: U.S. Geological Survey Open-File Map 71-56, scale 1:250,000.

Brosgé, W.P., Dutro, J.T., Jr., Mangus, M.D., and Reiser, H.N., 1962, Paleozoic sequence in eastern Brooks Range, Alaska: American Association of Petroleum Geologists Bulletin, v. 46, p. 174198.

Brozena, J.M., Childers, V.A., Lawver, L.A., Gahagan, L.M., Forsberg, R., Faleide, J.I., Eldholm, O., 2003. New aerogeophysical study of the Eurasia Basin and Lomonosov Ridge: implications for basin development. Geology 31, 825-828.

Carter, C., and Laufeld, S., 1975, Ordovician and Silurian fossils in well cores from North Slope of Alaska: American Association of Petroleum Geologists Bulletin, v. 59, p. 457-464.

Churkin, M., Jr., 1975, Basement rocks of Barrow Arch, Alaska, and circum-Arctic Paleozoic mobile belts: American Association of Petroleum Geologists, v. 59, no. 3, p. 451-456.

Churkin, M., Jr., Whitney, J.W., and Rogers, J.F., 1985, The North American-Siberian connection, a mosaic of craton fragments in a matrix of oceanic terranes, in Howell, D.G., ed., Tectonostratigraphic Terranes of the Circum-Pacific Region, Earth Science Series 1: Houston, Texas, Circum-Pacific Council for Energy and Mineral Resources, p. 79-84.

Cocks, L.R.M., and Torsvik, T.H., 2011, The Palaeozoic geography of Laurentia and western Laurussia: A stable craton with mobile margins: Earth Science Reviews, v. 106, p. 1-51.

Cook, D.B., Fujita, K., McMullen, C.A., 1986. Present-day plate interactions in Northeast Asia: North American, Eurasian, and Okhotsk plates. J. Geodyn. 6, 33-51.

Cook, F.A., Coflin, K.C., Lane, L.S., Dietrich, J.R., Dixon, 1987. Structure of the southeast margin of the Beaufort-Mackenzie basin, Arctic Canada, from crustal seismicreflection data. Geology 15, 931-935. 
Colpron, M., and Nelson, J.L., 2009, A Palaeozoic Northwest Passage: incursion of Caledonian, Baltican and Siberian terranes into eastern Panthalassa, and the early evolution of the North American Cordillera: Geological Society of London, Special Publications, v 318, p. 273-307.

Colpron, M., and Nelson, J.L., 2011, A Paleozoic Northwest Passage and the Timanian, Caledonian, and Uralian connections to some exotic terranes in the North American Cordillera, in, Spencer, A.M., Embry, A.F., Gautier, D.L., Stoupakova, A.V., and Sorensen, K., eds., Arctic Petroleum Geology, Geological Society of London Memoir 35, p. 463-484.

Cox, G.M., Strauss, J.V., Halverson, G.P., Schmitz, M.A., McClelland, W.C., Stevenson, R.S., and Macdonald, F.A., 2015, Kikiktat volcanics of Arctic Alaska-Melting of harzburgitic mantle associated with the Franklin large igneous province: Lithosphere, v. 7, no. 3, p. 275-295.

Davidson, J., Turner, S., and Plank, T., 2013. Dy/Dy*: Variations arising from mantle sources and petrogenetic processes. Journal of Petrology v. 54, no. 3, p. 525-537.

Dillon, J.T., 1989, Structure and stratigraphy of the southern Brooks Range and northern Koyukuk Basin near the Dalton Highway, in Mull, C.G., and Adams, K.E., Dalton Highway, Yukon River to Prudhoe Bay, Alaska: Bedrock Geology of the Eastern Koyukuk Basin, Central Brooks Range, and East-Central Arctic Slope, Alaska Division of Geological and Geophysical Surveys, Guidebook 7, v. 2, p. 157-187.

DeGraaff-Surpless, K., Graham, S. A., Wooden, J. L., \& McWilliams, M. O., 2002. Detrital zircon provenance analysis of the Great Valley Group, California: Evolution of an arc-forearc system. Geological Society of America Bulletin, 114(12), 1564-1580.

Dickinson, W. R., \& Gehrels, G. E., 2003. U-Pb ages of detrital zircons from Permian and Jurassic eolian sandstones of the Colorado Plateau, USA: paleogeographic implications. Sedimentary Geology, 163(1), 29-66.

Dillon, J.T., Brosgé, W.P., and Dutro, J.T., Jr., 1986, Generalized geologic map of the Wiseman quadrangle, Alaska: U.S. Geological Survey Open-File Report 86-219, scale 1:250,000.

Dinkelman, M.G., Kumar, N., Helwig, J., Emmet, P., Granath, J., 2008. Highlights of petroleum and crustal framework of the Beaufort-Mackenzie Basin: key results from BeaufortSPAN(TM) East Phases I and II surveys. Can. Soc. Explor. Geophys. Rec. 35, 22-25.

Dovzhikova, E., Pease, V., and Remizov, D., 2004., Neoproterozoic island are magmatism beneath the Pechora Basin, NW Russia, GFF, 126:4, 353-362, DOI: 10.1080/11035890401264353

Dumoulin, J.A., Harris, A.G., Bradley, D.C., and de Freitas, T.A., 2000, Facies patterns and conodont biogeography in Arctic Alaska and the Canadian Arctic Islands: Evidence against juxtaposition of these areas during Early Paleozoic time: Polarforschung, v. 68, p. 257-266.

Dumoulin, J.A., Harris, A.G., Gagiev, M., Bradley, D.C., and Repetski, J.E., 2002, Lithostratigraphic, conodont, and other faunal links between lower Paleozoic strata in northern and central Alaska 
and northeastern Russia, in Miller, E.L., Grantz, A., and Klemperer, S.L., eds., Tectonic evolution of the Bering Shelf-Chukchi Sea-Arctic Margin and Adjacent Landmasses: Geological Society of America Special Paper 360, p. 291-312.

Dumoulin, J.A., Harris, A.G., and Repetski, J.E., 2014, Carbonate rocks of the Seward Peninsula, in Dumoulin, J.A., and Till, A.B., eds., Reconstruction of a Late Proterozoic to Devonian Continental Margin Sequence, Northern Alaska: Its Paleogeographic Significance and Contained Base-Metal Sulfide Deposits: Geological Society of America Special Paper 506.

Dutro, J.T., Jr., Brosgé W.P., Lanphere, M.A., and Reiser, H.N., 1976, Geologic significance of Doonerak structural high, central Brooks Range, Alaska: American Association of Petroleum Geologists Bulletin, v. 60, p. 952-961.

Dutro, J.T., Jr., Palmer, A.R., Repetski, J.E., and Brosgé W.P., 1984a, The Doonerak anticlinorium revisited, in Coonrad, W.L., and Elliot, R.L., eds., The U.S. Geological Survey in Alaska Accomplishments during 1981: U.S. Geological Survey Circular 868, p. 17-19.

Dutro, J.T., Jr., Palmer, A.R., Repetski, J.E., and Brosgé W.P., 1984b, Middle Cambrian fossils from the Doonerak anticlinorium, central Brooks Range, Alaska: Journal of Paleontology, v. 58, p. 1364-1371.

Engen, Ø., Eldholm, O., Bungum, H., 2003. The Arctic plate boundary. J. Geophys. Res. B 108 (2). http://dx.doi.org/10.1029/2002JB001809 (ETG 5-1-5-17).

Floyd, P. A., and Winchester, J. A., 1978. Identification and discrimination of altered and metamorphosed volcanic rocks using immobile elements. Chemical Geology v. 21, no. 3, p. 291306.

Fryer BJ, Jackson SE, Longerich HP. 1993. The application of laser ablation microprobe-inductively coupled plasma mass spectrometry (LAM-ICPMS) to in situ (U)-Pb geochronology. Chem. Geol. 109:1-8

Gee, D. G., 1975. A tectonic model for the central part of the Scandinavian Caledonides. American Journal of Science, v. 275A, p. 468-515.

Gee, D. G., \& Pease, V., 2004. The Neoproterozoic Timanide Orogen of eastern Baltica: introduction. In Gee, D. G. \& Pease, V . (eds) 2004. The Neoproterozoic Timanide Orogen of Eastern Baltica. Geological Society, London, Memoirs, 30, 1-3. 0435-4052/04/\$15

Gee, D., Johansson, Å., Ohta, Y., and Tebenkov, A., 1995, Grenvillian basement and a major unconformity within the Caledonides of Nordaustlandet, Svalbard: Precambrian Research, v. 70, no. 3-4, p. 215-234, doi:10.1016/0301-9268(94)00041-O.

Gehrels, G. 2014. Detrital zircon U-Pb geochronology applied to tectonics. Annu. Rev. Earth Planet. Sci. 2014. 42:127-49 doi: 10.1146/annurev-earth-050212-124012 
Gehrels, G.E., Valencia, V., Ruiz, J., 2008, Enhanced precision, accuracy, efficiency, and spatial resolution of U-Pb ages by laser ablation-multicollector-inductively coupled plasma-mass spectrometry: Geochemistry, Geophysics, Geosystems, v. 9, Q03017, doi:10.1029/2007GC001805.

Glebovsky, V.Yu., Kaminsky, V.D., Minakov, A.N., Merkur'ev, S.A., Childers, V.A., Brozena, J. M., 2006. Formation of the Eurasia Basin in the Arctic Ocean as inferred from geohistorical analysis of the anomalous magnetic field. Geotectonics v.40 no.4, p. 263-281.

Gottlieb, E.S., Meisling, K.E., Miller, E.L., and Mull, C.G., 2014, Closing the Canada Basin: Detrital zircon geochronology relationships between the North Slope of Arctic Alaska and the Franklinian mobile belt of Arctic Canada: Geosphere, v. 10, no. 6, p. 1-19.

Gottschalk, R.R. and Snee, L.W., 1998. Tectonothermal evolution of metamorphic rocks in the southcentral Brooks Range, Alaska: Constraints from 40Ar/39Ar geochronology. Geological Society of America Special Papers, 324, p.225-251.

Grantz, A., Moore, T.E., and Roeske, S.M., 1991, Continent-ocean transect A-3: Gulf of Alaska to Arctic Ocean: Geological Society of America Centennial Continent/Ocean Transect 15, 72 p., 3 sheets, scale 1:500 000 .

Grantz, A., Pease, V.L., Willard, D.A., Phillips, R.L., Clark, D.L., 2001. Bedrock cores from 898 North: implications for the geologic framework and Neogene paleoceanography of Lomonosov Ridge and a tie to the Barents shelf. Geol. Soc. Am. Bull. 113, 1272-1281.

Grantz, A., Hart, P., May, S.D., Coastal, W.R., 2004. Seismic reflection and refraction data acquired in Canada Basin, Northwind Ridge, and Northwind Basin, Arctic Ocean in 1988, 1992 and 1993. US Geological Survey, Reston, VA, Open-file Reports, 2004-1243 (World Wide Web Address http://pubs.usgs.gov/of/2004/1243/).

Grantz, A., May, S., Hart, P., 1990. Geology of the Arctic continental margin of Alaska. Geol. North Am. 50, p. 257-288.

Grantz, A., Dinter, D.A., and Culotta, R.C., 1987, Structure of the continental shelf north of the Arctic National Wildlife Refuge, in Bird, K.J., and Magoon, L.B., eds., Petroleum geology of the northern part of the Arctic National Wildlife Refuge, northeastern Alaska: U.S. Geological Survey Bulletin v. 1778, p. 271-276.

Grantz, A., and May, S. D.,1983. Rifting history and structural development of the continental margin north of Alaska. Studies in continental margin geology: AAPG Memoir, v. 34, p. 77-100.

Grantz, A., Hart, P., Childers, V., 2011a. Geology and tectonic development of the Amerasia and Canada Basins, Arctic Ocean. In: Spencer, A.M., Embry, A.F., Gautier, D.L., Stoupakova, A.V., Sørensen, K. (Eds.), Arctic Petroleum Geology. Geological Society (London) Memoirs, 35, pp. 771-799. 
Grantz, A., Scott, R.A., Drachev, S.S., Moore, T.E., Valin, Z.C., 2011b. Sedimentary successions of the Arctic Region (58-64 to $90^{\circ} \mathrm{N}$ ) that may be prospective for hydrocarbons. In: Spencer, A.M., Embry, A.F., Gautier, D.L., Stoupakova, A.V., Sørensen, K. (Eds.), Arctic Petroleum Geology. Geological Society (London) Memoirs, 35, pp. 17-37.

Grove, M., Gehrels, G.E., Cotkin, S.J., Wright, J.E., and Zou, H., 2008, Non-Laurentian cratonal provenance of Late Ordovician eastern Klamath blueschists and a link to the Alexander terrane, in Wright, J.E., and Shervais, J.W., eds., Ophiolites, arcs and batholiths: A tribute to Cliff Hopson: Geological Society of America Special Paper 438, p. 223-250.

Hadlari, T., Davis, W.J., Dewing, K., 2014. A peri-cratonic model for Pearya Terrane as an extension of the Franklinian margin of Laurentia, Canadian Arctic. Geol. Soc. Am. Bull. 126 (1-2), 182200

Hanson, G. N., 1980. Rare earth elements in petrogenetic studies of igneous systems. Annual Review of Earth and Planetary Sciences v. 8, no. 1, p.371-406.

Hawkesworth, C. J., Gallagher, K., Hergt, J. M., McDermott, F., 1993, Mantle and slab contributions in arc magmas. Annual Review of Earth and Planetary Sciences, 21(1), p. 175-204.

Helwig, J., Kumar, N., Emmet, P., Dinkelman, M.G., 2011. Regional seismic interpretation of crustal framework, Canadian Arctic passive margin, Beaufort Sea, with comments on petroleum potential. In: Spencer, A.M., Embry, A.F., Gautier, D.L., Stoupakova, A.V., Sørensen, K. (Eds.), Arctic Petroleum Geology. Geological Society (London) Memoirs, 35, pp. 527-543.

Houseknecht, D.W., and Connors, C.D., 2016, Pre-Mississippian tectonic affinity across the Canada Basin-Arctic margins of Alaska and Canada: Geology, v. 44, n. 7, p. 507-510.

Humphries, S.E., 1984, The mobility of the rare earth elements in the crust. In: Henderson, P. (ed.), Rare earth element geochemistry. Elsevier, Amsterdam, p. 315-341

Jaffey AH, Flynn KF, Glendenin LE, Bentley WC, Essling AM. 1971. Precision measurement of halflives and specific activities of ${ }^{235} \mathrm{U}$ and ${ }^{238} \mathrm{U}$. Phys. Rev. C4:1889-906

Johansson, Å., Larionov, A.N., Gee, D.G., Ohta, Y., Teben’kov, A.M., and Sadelin, S., 2004, Grenvillian and Caledonian tectonomagmatic activity in northeasternmost Svalbard, in Gee, D.G., and Pease, V., eds., The Neoproterozoic Timanide Orogen of Eastern Baltica: Geological Society of London Memoir 30, p. 207-232.

Johansson, Å., Gee, D., Larionov, A., Ohta, Y., and Tebenkov, A., 2005, Grenvillian and Caledonian evolution of eastern Svalbard-A tale of two orogenies: Terra Nova, v. 17, p. 317 325, doi:10.1111/j.1365-3121.2005.00616.x.

Johnson, B.G., Strauss, J.V., Toro, J., Benowitz, J.A., and Ward, W.P., in review, Geochronological constraints from synorogenic detritus and early Paleozoic accretionary tectonics in the NE Brooks Range: Lithosphere, v. 8, no.6; p. 649-667. 
Jokat, W., Uenzelmann-Neben, G., Kristoffersen, Y., Rasmussen, T.M., 1992. Lomonosov Ridge - a double-sided continental margin. Geology 20, 887-890.

Jones, D. L., Bounday-Sanders, S., Murray, R. L , Howell, D. G., and Wiley, T. J., 1987. Tectonic contacts of miogeoclinal strata in east-central Alaska: American Association of Petroleum Geologists Abstracts with Programs, V. 7J, p. 573.

Jones, P. B., 1982, Mesozoic rifting in the western Arctic ocean basin and its relationship to Pacific seafloor spreading, in Embry, A. F., and Balkwill, H. R., eds., Arctic geology and geophysics; Proceedings of the Third International Symposium on Arctic Geology: Canadian Society of Petroleum Geologists Memoir 8, p. 83- 99.

Julian, F.E., 1989, Structure and stratigraphy of lower Paleozoic rocks, Doonerak Window, central Brooks Range, Alaska (Ph.D. Thesis): Houston, Texas, Rice University, 127 p.

Julian, F.E., and Oldow, J.S., 1998, Structure and lithology of the lower Paleozoic Apoon Assemblage, eastern Doonerak Window, central Brooks Range, Alaska, in Oldow, J.S., and Ave Lallemant, H.G., eds., Architecture of the central Brooks Range fold and thrust belt, Arctic Alaska: Geological Society of America Special Paper 324, p. 65-80.

Karasik, A.M., 1968. Magnetic Anomalies of the Gakkel Ridge and the origin of the Eurasia Subbasin of the Arctic Ocean. Geofizicheskie metody razvedki i Arktike 5, 8-19 (in Russian).

Karasik, A.M., 1974. The Eurasia Basin of the Arctic Ocean from the Point of View of Plate Tectonics: Problems in Geology of Polar Regions of the Earth. NauchnoIsseledovateliskiy Institut Geologii, Leningrad, (in Russian).

Kos’ko, M.K., Cecile, M.P., Harrison, J.C., Banelin, V.G., Khandoshko, N.V., and Lopatin, B.G., 1993, Geology of Wrangel Island, between Chukchi and East Siberian seas, northeastern Russia: Geological Survey of Canada Bulletin, v. 461, 101 p.

Košler J, Sylvester PJ. 2003. Present trends and the future of zircon in U-Pb geochronology: laser ablation` ICPMS. See Hanchar \& Hoskin 2003, pp. 243-75

Košler J, Fonneland H, Sylvester P, Tubrett M, Pedersen R-B. 2002. U-Pb dating of detrital zircons for sediment provenance studies-a comparison of laser ablation ICPMS and SIMS techniques. Chem. Geol. 182: 605-18

Košler J, Tubrett M, Sylvester P. 2001. Application of laser ablation ICPMS to U-Th-Pb dating of monazite. Geostand. Newsl. 25: 375-86

Košler J, Sláma J, Belousova E, Corfu F, Gehrels GE, et al. 2013. U-Pb detrital zircon analysis—results of inter-laboratory comparison. Geostand. Geoanal. Res. 37: 243-59 
Kristoffersen, Y., 1990. Eurasia Basin. In: Grantz, A., Johnson, G.L., Sweeney, J.F. (Eds.), The Arctic Ocean region. The Geology of North America, L. Geological Society of America, Boulder, CO, pp. 365-378.

Lane, L.S., 1997. Canada Basin, Arctic Ocean: evidence against a rotational origin. Tectonics 5, 252276.

Lane, L.S., 2007, Devonian-Carboniferous paleogeography and orogenesis, northern Yukon and adjacent Arctic Alaska: Canadian Journal of Earth Sciences, v. 44, p. 679-694.

Lane, L.S., Gehrels, G.E., and Layer, P.W., 2015, Provenance and paleogeography of the Neruokpuk Formation, northwest Laurentia: An integrated synthesis: Geological Society of America Bulletin.

Lawver, L.A., and Scotese, C.R., 1990, A review of tectonic models for the evolution of the Canadian Basin, in Grantz, A., et al., eds., The Arctic Ocean region: Boulder, Colorado, Geological Society of America, Geology of North America, v. L, p. 593-618.

Laxon, S., McAdoo, D., 1994. Arctic Ocean gravity field derived from ERS-1 satellite altimetry. Science 265, 621-624.

Laxon, S.W., McAdoo, D.C., 1998. Satellites provide new insights into Polar geophysics. EOS Trans. 79 (69), 72-73.

Le Bas, M. J., 1986. A chemical classification of volcanic rocks based on the total alkali-silica diagram. Journal of Petrology, 27, 745-750.

Le Maitre, R. W., Streckeisen, A., Zanettin, B., Le Bas, M. J., Bonin, B., Bateman, P, \& Lameyre, J., 2002. Igneous Rocks: A Classification and Glossary of Terms: Recommendations of the International Union of Geological Sciences, Subcommission on the Systematics of Igneous Rocks. Cambridge University Press, Cambridge

LePain, D.L., Crowder, R.K., and Wallace, W. K., 1994, Early Carboniferous transgression on a passive continental margin: deposition of the Kekiktuk conglomerate, northeastern Brooks Range, Alaska. AAPG Bulletin, v. 78, no. 5, p. 679-699.

Lerand, M., 1973, Beaufort Sea, in McCrossam, R.G., ed., The Future Petroleum Provinces of Canada — Their Geology and Potential: Canadian Society of Petroleum Geology Memoir 1, p. 315-386.

Louden, K., Osler, J., Srivastava, S., Keen, C., 1996. Formation of oceanic crust at slow spreading rates: new constraints from an extinct spreading center in the Labrador Sea. Geology 24, 771774.

Macdonald, F.A., McClelland, W.C., Schrag, D.P., and Macdonald, W.P., 2009, Neoproterozoic glaciation on a carbonate platform margin in Arctic Alaska and the origin of the North Slope subterrane: Geological Society of America Bulletin, v. 121, p. 448-473. 
Mayfield, C. F., Tailleur, I. L., and Ellersieck, I., 1988, Stratigraphy, structure, and palinspastic synthesis of the western Brooks Range, northwestern Alaska, in Geology and Exploration of the National Petroleum Reserve in Alaska, 1974 to 1982, edited by G. Gryc, U.S. Geol. Surv. Prof. Paper, 1399, p.143-186.

McClelland, W.C., Colpron, M., Piepjohn, K., von Gosen, W., Ward, W., and Strauss, J.V., 2015, Preliminary detrital zircon geochronology of the Neruokpuk Formation in the Barn Mountains, Yukon: in Yukon Exploration and Geology, K.E. MacFarlane, M.G. Nordling, and P.J. Sack (eds.), Yukon Geological Survey, p. 123-143.

McDonough, W.F. and Sun, S.S., 1995. The composition of the Earth. Chemical geology, v. 120 no. 34, p.223-253.

McKerrow, W. S., Mac Niocaill, C., \& Dewey, J. F., 2000. The Caledonian orogeny redefined. Journal of the Geological Society, v. 157 no. 6, p. 1149-1154.

McLennan, S.L., 1989, Rare Earth Elements in Sedimentary Rocks: influence of Provenance and Sedimentary Processes in Lipin, B.R. and McKay G.A., eds., Geochemistry and Mineralogy of Rare Earth Elements, Reviews in Mineralogy, vol. 21, pgs. 169-200.

Miller, E.L., Toro, J., Gehrels, G., Amato, J.M., Prokopiev, A., Tuchkova, M.I., Akinin, V.V., Dumitru, T.A., Moore, T.E., and Cecile, M.P., 2006, New insights into Arctic paleogeography and tectonics from U-Pb detrital zircon geochronology: Tectonics, v. 25, TC3013, 19 p.

Miller, E., Gehrels, G., Pease, V., and Sokolov, S., 2010, Stratigraphy and U-Pb detrital zircon geochronology of Wrangel Island, Russia: Implications for Arctic paleogeography: AAPG bulletin, v. 94, no. 5, p. 665 .

Miller, E.L., Kuznetsov, N., Soboleva, A., Udoratina, O., Grove, M.J., and Gehrels, G., 2011, Baltica in the Cordillera?: Geology, v. 39, no. 8, p. 791-794, doi: 10.1130/G31910.1.

Moore, T.E., 1987, Geochemical and tectonic setting of some volcanic rocks of the Franklinian assemblage, central and eastern Brooks Range, in Tailleur, I.L. and Weimer, P., eds., Alaskan North Slope Geology: Bakersfield, California, Society of Economic Paleontologists and Mineralogists, Pacific Section, and Alaska Geological Society, Book 50, p. 691-710.

Moore, T.E. and Churkin, M., Jr., 1984, Ordovician and Silurian graptolite discoveries from the Neruokpuk Formation (sensu lato), northeastern and central Brooks Range, Alaska: Paleozoic Geology of Alaska and Northwestern Canada Newsletter, no. 1, p. 21-23.

Moore, T.E., Wallace, W.K., Bird, K.J., Karl, S.M., Mull, C.G., and Dillon, J.T., 1994, Geology of northern Alaska, in Plafker, G., and Berg, H.C., eds., The Geology of Alaska: Boulder, Colorado, Geological Society of America, The Geology of North America, v. G-1, p. 49-140. 
Moore, T.E., Wallace, W.K., Mull, C.G., Adams, K.E., Plafker, G., and Nokleberg, W.J., 1997, Crustal implications of bedrock geology along the Trans-Alaska Crustal Transect (TACT) in the Brooks Range, northern Alaska: Journal of Geophysical Research, v. 102, no. B9, p. 20645-20684.

Moore, T.E., Potter, C.J., and O’Sullivan, P.B., 2007, Detrital zircon U-Pb analysis of preMississippian metasedimentary basement strata, North Slope, Alaska: Evidence of a Caledonian connection: Geological Society of America Abstracts with Programs, v. 39, no. 6, p. 488.

Moore, T.E., O’Sullivan, P.B., Potter, C.J., and Donelick, R.A., 2015, Provenance and detrital zircon geochronologic evolution of lower Brookian foreland basin deposits of the western Brooks Range, Alaska, and implications for early Brookian tectonism: Geosphere, v. 11, no. 1, p. 93122.

Mosher, D.C., Shimeld, J., Hutchinson, D., Chian, D., Lebedova-Ivanova, Jackson, R., 2012. Canada Basin revealed. Arctic Technology Conference Proceedings, OTC 23797 (11 pp.).

Mull, C.G., 1982, The tectonic evolution and structural style of the Brooks Range, Alaska: An illustrated summary, in Powers, R.B., ed., Geological Studies of the Cordilleran Thrust Belt, Volume 1: Denver, Colorado, Rocky Mountain Association of Geologists, p. 1-45.

Mull, C.G., Adams, K.E., and Dillon, J.T., 1987a, Stratigraphy and structure of the Doonerak fenster and Endicott Mountains allochthon, central Brooks Range, Alaska, in Tailleur, I., and Weimer, P., eds., Alaskan North Slope Geology: Bakersfield, California, Society of Economic Paleontologists and Mineralogists (SEPM), Pacific Section, and Alaska Geological Society, Book 50, p. 663-679.

Mutter, J.C., Karson, J.A., 1992. Structural processes at slow-spreading ridges. Science 257, 627-634.

Nakamura, N. 1974. Determination of REE, Ba, Fe, Mg, Na and K in carbonaceous and ordinary chondrites. Geochimica et Cosmochimica Acta v38, p. 757-775.

Natal'in, B.A., Amato, J.M., Toro, J., and Wright, J.E., 1999, Paleozoic rocks of northern Chukotka Peninsula, Russian Far East: Implications for the tectonics of the Arctic region: Tectonics, v. 18, p. 977-1003.

Nokleberg, W.J., Parfenov, L.M., Monger, J.W., Norton, I.O., Chand'uk, A.I., Stone, D.B., Scotese, C.R., Scholl, D.W., Fujita, K., 2000. Phanerozoic Tectonic Evolution of the Circum-North Pacific. US Department of the Interior, US Geological Survey.

Oldow, J.S., Avé Lallemant, H.G., Julian, F.E., and Seidensticker, C.M., 1984, The Doonerak window duplex: regional implications: Geological Society of America Abstracts with Programs, v. 16, p. 326.

Oldow, J.S., Avé Lallemant, H.G., Julian, F.E., and Seidensticker, C.M., 1987a, Balanced cross sections through the central Brooks Range and North Slope, Arctic Alaska: American Assoication of Petroleum Geologists Special Publication, v. 19, 19 p., 8 plates. 
Oldow, J.S., Avé Lallemant, H.G., Julian, F.E., and Seidensticker, C.M., 1987b, Ellesmerian(?) and Brookian deformation in the Franklin Mountains, northeastern Brooks Range, Alaska, and its bearing on the origin of the Canada Basin: Geology, v. 15, p. 37-41.

O’Sullivan, P.B., Moore, T.E. and Murphy, J.M., 1998. Tertiary uplift of the Mt. Doonerak antiform, central Brooks Range, Alaska: Apatite fission-track evidence from the Trans-Alaska Crustal Transect, in Architecture of the Central Brooks Range Fold and Thrust Belt, Arctic Alaska, edited by Oldow, J., and Avé Lallement, H., p.179.

Oxman, V. S., 2003. Tectonic evolution of the Mesozoic Verkhoyansk-Kolyma belt (NE Asia). Tectonophysics, 365(1), 45-76.

Pallister, J.S., Budahn, J.R. and Murchey, B.L., 1989. Pillow basalts of the Angayucham terrane: Oceanic plateau and island crust accreted to the Brooks Range. Journal of Geophysical Research: Solid Earth, 94, p.15901-15923.

Paton, C., Hellstrom, J., Paul, B., Woodhead, J., \& Hergt, J. 2011. Iolite: Freeware for the visualisation and processing of mass spectrometric data. Journal of Analytical Atomic Spectrometry, v. 26, p. 2508-2518.

Patton, W.W., Jr., Box, S. E., and Grybeck, D. J., 1994, Ophiolites and other mafic-ultramalic complexes in Alaska, in Plafker, G., and Berg, H. C., eds., The Geology of Alaska: Boulder, Colorado, Geological Society of America, The Geology of North America, v. G-1, p. 671-686.

Patrick, B.E., and McClelland, W.C., 1995, Late Proterozoic granitic magmatism on Seward Peninsula and a Barentian origin for Arctic Alaska-Chukotka: Geology, v. 23, p. 81-84.

Pearce, J.A., 1983. Role of the sub-continental lithosphere in magma genesis at active continental margins. In Hawksworth, C.J. and Norry, M. J. (eds.), Continental basalts and mantle xenoliths. Shiva, Nantwich, p. 230-249

Pearce, J.A., and Cann, J., 1973. Tectonic setting of basic volcanic rocks determined using trace element analysis. Earth Planet. Sci. Lett., v. 19, p. 290-300.

Pease, V., 2011, Eurasian orogens and Arctic tectonics: an overview, in Spencer, A.M., Embry, A.F., Gautier, D.L., Stoupakova, A.V., and Sorensen, K., eds., Arctic Petroleum Geology: Geological Society, London, Memoir 35, p. 311-324.

Pease, V., Drachev, S., Stephenson, R., \& Zhang, X., 2014. Arctic lithosphere-A review. Tectonophysics, v. 628, p. 1-25.

Pease, V., Dovzhikova, E., Beliakova, L., \& Gee, D. G., 2004. Late Neoproterozoic granitoid magmatism in the basement to the Pechora Basin, NW Russia: geochemical constraints indicate westward subduction beneath NE Baltica. Geological Society, London, Memoir 30, p 75-85. 
Ramsay, D. M. \& Sturt, B. A., 1976, The syn-metamorphic emplacement of the Magerøy Nappe. Norsk Geologisk Tidsskrift, Vol. 56, pp. 291-307.

Reed, B. L., 1968, Geology of the Lake Peters area, northeastern Brooks Range, Alaska: U.S. Geological Survey Bulletin, v. 1236, p. 1-132.

Remizov, D., and Pease, V., 2004. The Dzela complex, Polar Urals, Russia: a Neoproterozoic island arc in The Neoproterozoic Timanide Orogen of eastern Baltica (eds.) Gee, D. G., and Pease, V., Geological Society of London, Memoir 30, p. 107 - 123.

Repetski, J.E., Carter, C., Harris, A.G., and Dutro, J.T. Jr., 1987, Ordovician and Silurian fossils from the Doonerak anticlinorium, central Brooks Range, Alaska, in Hamilton, T.D., and Galloway, J.P., eds., Geologic studies in Alaska by the U.S. Geological Survey during 1986: U.S. Geological Survey Circular 998, p. 40-42.

Roberts, D., 2003. The Scandinavian Caledonides: event chronology, palaeogeographic settings and likely modern analogues. Tectonophysics, v. 365 no. 1, p. 283-299.

Roberts, D and Olovyanishnikov, V., 2004, Structural and tectonic development of the Timanide orogen in The Neoproterozoic Timanide Orogen of eastern Baltica (eds.) Gee, D. G., and Pease, V., Geological Society of London, Memoir 30, p. 47 - 57.

Roeder, D., and Mull, C. G., 1978., Tectonics of Brooks Range ophiolites, Alaska, AAPG Bull., v. 62, p. 1696-1702.

Sable, E.G., 1977, Geology of the western Romanzof Mountains, Brooks Range, northeastern Alaska: U.S. Geological Survey Professional Paper 897, 84 p. Saleeby, J.B., 1983, Accretionary tectonics of the North American Cordillera: Annual Review of Earth and Planetary Sciences, v. 11, p. 4573, doi:10.1146/annurev.ea.11.050183.000401.

Salters, V. J. M. \& Stracke, A. 2004. Composition of the depleted mantle. Geochemistry, Geophysics, Geosystems 5, doi:10.1029/ 2003GC000,597

Saltus, R.W., Miller, E.M., Gaina, C., Brown, P.J., 2011. Regional magnetic domains of the circumArctic - a framework for geodynamic interpretation. In: Spencer, A.M., Embry, A.F., Gautier, D.L., Stoupakova, A.V., Sørensen, K. (Eds.), Arctic Petroleum Geology. Geological Society (London) Memoirs, 35, pp. 49-60.

Savostin, L.A., Karasik, A.M., 1981. Recent plate tectonics of the Arctic basin and of northeastern Asia. Tectonophysics 74, 111-145.

Shervais, J. W., 1982. Ti-V plots and the petrogenesis of modern and ophiolitic lavas. Earth and planetary science letters, v. 59, no. 1, p. 101-118.

Silberling, N.L., Jones, D.L., Monger, J.W.H., Coney, P.J., Berg, H.C. and Plafker, G., 1994. Lithotectonic terrane map of Alaska and adjacent parts of Canada, in Plafker, G., and Berg, H.C., 
eds., The Geology of Alaska: Boulder, Colorado, Geological Society of America, The Geology of North America, v. G-1, 1 sheet, 1:250000.

Small, C., Sandwell, D.T., 1992. An analysis of ridge axis gravity roughness and spreading rate. J. Geophys. Res. Solid Earth 97, 3235-3245 (1978-2012).

Spencer, A.M., Embry, A.F., Gautier, D.L., Stoupakova, A.V., Sørensen, K., 2011. An overview of the petroleum geology of the Arctic. In: Spencer, A.M., Embry, A.F., Gautier, D.L., Stoupakova, A.V., Sørensen, K. (Eds.), Arctic Petroleum Geology. Geological Society (London) Memoirs, 35, pp. 1-15.

Strauss, J.V., Macdonald, F.A., Taylor, J.F., Repetski, J.E., and McClelland, W.C., 2013, Laurentian origin for the North Slope of Alaska: Implications for the tectonic evolution of the Arctic: Lithosphere, v. 5, no. 5, p. 477-482.

Strauss, J. V., Hoiland, C. W., Ward, W. P., Johnson, B. G., Nelson, L. L., \& McClelland, W. C., 2017, Orogen transplant: Taconic-Caledonian arc magmatism in the central Brooks Range of Alaska. Geological Society of America Bulletin, 129 (5-6), p. 649-676.

Sturt, B. A., Pringle, I. R., \& Ramsay, D. M., 1978. The Finnmarkian phase of the Caledonian orogeny. Journal of the Geological Society, 135(6), 597-610.

Sun, S.S., and McDonough, W.F., 1989, Chemical and isotopic systematics of oceanic basalts: implications for mantle composition and processes, in Saunders, A.D. and Norry, M.J., eds., Magmatism in Ocean Basins: Geological Society of London Special Publication No. 42, p. 313345.

Tailleur, l. L ... and Brosgé, W. P., 1970, Tectonic history of northern Alaska. In Adkison, W. L., and Brosgé, M. M., eds., Proceedings, Geological seminar on the North Slope of Alaska: Los Angeles, American Association of Petroleum Geologists Pacific Section Meeting, p. El- E20.

Tatsumi, Y., The subduction factory: How it operates in the evolving Earth. GSA Today: v. 15, no. 7, p. 4-10 doi: 10:1130/1052-5173(2005)015<4:TSFHIO>2.0.CO;2

Till, A.B., Dumoulin, J.A., Harris, A.G., Moore, T.E., Bleick, H., and Siwiec, B., 2008, Bedrock geologic map of the southern Brooks Range, Alaska, and accompanying conodont data: U.S. Geological Survey Open-File Report 2008-1149, 88 p., 2 sheets.

Till, A.B., Amato, J.M., Aleinikoff, J.N., and Bleick, H.A., 2014a, U-Pb detrital zircon geochronology as evidence for the origin of the Nome Complex, northern Alaska, and implications for regional and trans-Arctic correlations, in Dumoulin, J.A., and Till, A.B., eds., Reconstruction of a Late Proterozoic to Devonian Continental Margin Sequence, Northern Alaska: Its Paleogeographic Significance and Contained Base-Metal Sulfide Deposits: Geological Society of America Special Paper 506, p. 111-131.

Till, A.B., Dumoulin, J.A., Ayuso, R.A., Aleinikoff, J.N., Amato, J.M., Slack, J.F., and Shanks, W.C.P., III, 2014b, Reconstruction of an early Paleozoic continental margin basin on the nature 
of protoliths in the Nome Complex, Seward Peninsula, Alaska, in Dumoulin, J.A., and Till, A.B., eds., Reconstruction of a Late Proterozoic to Devonian Continental Margin Sequence, Northern Alaska: Its Paleogeographic Significance and Contained Base-Metal Sulfide Deposits:

Geological Society of America Special Paper 506.

Trettin, H.P., 1987, Pearya: A composite terrane with Caledonian affinities in northern Ellesmere Island: Canadian Journal of Earth Sciences, v. 24, p. 224-245.

Trettin H.P., 1998, Pre-Carboniferous geology of the northern part of the Arctic islands, Chapter 4: Geology of Pearya: Geological Survey Canada Bulletin, v. 425, pp. 108-192.

Turner, D. L., Forbes, R. B., and Dillon, J. T., 1979, K-Ar geochrooometry of the southwestern Brooks Range, Alaska: Canadian Journal of Earth Sciences, v. 16. p. 1789- 1804.

Vogt, P.R., Taylor, P.T., Kovacs, L.C., Johnson, G.L., 1979. Detailed aeromagnetic investigation of the Arctic Basin. J. Geophys. Res. Solid Earth 84, 1071-1089.

Vogt, P., Jung, W., Jakobsson, M., Mayer, L., Williamson, M., 2006. The Alpha Mendeleev Magmatic Province, Arctic Ocean: a new synthesis. EOS Trans. Am. Geophys. Union 87, 36.

Wiedenbeck, M. A. P. C., Alle, P., Corfu, F., Griffin, W. L., Meier, M., Oberli, F. V., \& Spiegel, W. 1995. Three natural zircon standards for U-Th-Pb, Lu-Hf, trace element and REE analyses. Geostandards and Geoanalytical Research, 19(1), p. 1-23.

Winchester, J. A., and Floyd, P. A., 1977. Geochemical discrimination of different magma series and their differentiation products using immobile elements. Chemical geology v. 20, p.325-343.

Zonenshain, L.P., Natapov, L.M., 1989. Tectonic history of the Arctic Region from the Ordovician through the Cretaceous. In: Herman, Y. (Ed.), The Arctic Seas: Climatology, Oceanography, Geology and Biology. Van Nostrand Reinhold, New York, pp. 829-862. 


\section{SUPPLEMENTARY MATERIALS $\backslash$ APPENDIX}

\section{NOTE ON THE NOMENCLATURE OF SAMPLE DESCRIPTIONS/NAMES}

Reconnaissance scale mapping of the Wiseman Quadrangle by Dillon et al. (1986) and

Brosge and Reiser (1960 \& 1971) are the most current and comprehensive geological maps in the vicinity of the Doonerak fenster in the central Brooks Range. Some detailed mapping and stratigraphic studies were conducted in the eastern part of the fenster by Julian (1989) and Strauss et al., (2017). Additional regional work by Mull et al. (1987) and Moore (1987) add further complexity to the nomenclature of major rock units making the comparison of results increasingly difficult. For these reasons and to increase comparability, I utilized on the mapping and unit descriptions of the most recent published work from Doonerak - Strauss et al. (2017). This nomenclature recycles the nomenclature of Julian (1989) and Julian and Oldow (1998) for the lower Paleozoic volcanic rocks of the Doonerak fenster (Apoon assemblage) but otherwise generally remains consistent with Dillon et al., (1986). Even so, it is important to acknowledge

the difficulty of defining precise unit boundaries in an area of poorly constrained stratigraphic relations. The samples from this study can be generally divided into those from the Endicott Mountains allochthon (above the Amawk thrust), those from the Doonerak fenster but above the regionally recognizable pre-Mississippian unconformity (Ellesmerian Sequence), and those from the Doonerak fenster and below the major unconformity (Apoon assemblage). The sample summary table (below) includes the sample locations and types of analysis pertaining to the various samples. It also shows samples available for potential future analysis.

\section{NOTE ON DETRITAL ZIRCON SAMPLE PREPARATION}

Zircon-rich separates were acquired from whole rock samples by mechanical disaggregation and by density and magnetic differentiation of the resulting rock powders in the 
rock preparation lab at West Virginia University. This procedure was adapted from the standardized protocol used by the Arizona LaserChron Center and other laser ablation labs (e.g. e.g. Gehrels, 2014).

Samples were disaggregated to $<\sim 250 \mu \mathrm{m}$ particle sizes using a jaw crusher (Bico Braun Chipmunk) and disc mill (Bico Braun UA Pulverizer). After each crushing or pulverizing step, all material finer than $250 \mu \mathrm{m}$ was removed from further disaggregation via standard U.S. series sieves (No. 60 - opening .0098 in; $250 \mu \mathrm{m}$ ). Sieves were thoroughly cleaned before and after each sample using an air compressor, fine brush, and alcohol wash. Each sieve was visually inspected prior to use to ensure no foreign material was added to the separate.

The disaggregated rock powders were then separated based on their hydrodynamic characteristics (mainly density) using a shaking water table (MD Mineral Technologies MK2 Gemini). The most dense sample grains, those that entered the most distant three of seven receptacles attached to the water table, proceeded to further processing. Less dense material which entered the upper four receptacles was examined, dried, and archived when found to be absent of zircon.

The densest grains were then separated by their magnetic properties. First a hand magnet was used to remove highly magnetic material (mostly iron filings incorporated during crushing and pulverizing). Samples were then progressively separated according to magnetic susceptibility when exposed to an electromagnet within an L-1 Frantz isodynamic magnetic separator operating at a vertical angle of 15 degrees. Paramagnetic grains were removed from the sample in $~ 0.25$ ampere increments up to $~ 1.5$ amperes, and archived progressively. Nonmagnetic fractions at $~ 1.5$ amperes were retained for further processing. 
The nonmagnetic dense mineral fractions were then combined with a lithium polytungstate solution ( LPT; density $=2.85 \pm 0.02 \mathrm{~g} / \mathrm{mL}$ ) in a $\sim 50 \mathrm{~mL}$ glass funnel fixed with a gasket and rotatable valve at the base. Each sample was agitated and allowed to settle for approximately 45 min within the LPT, until grains could be observed within distinct floating and sunken fractions with an intervening clear heavy liquid zone between them. The gasket at the base of the funnel was then briefly opened to allow the dense mineral fraction to fall into a second glass funnel fixed with filter paper. Dense separates were then washed repeatedly using deionized water, sonicated, and dried before proceeding to further processing. The lighter mineral fraction was similarly treated, washed repeatedly, inspected to confirm the absence of zircon, and archived.

The nonmagnetic mineral separates denser than LPT proceeded to further heavy liquid processing. The densest grains from previous steps were combined with a methylene iodide solution (MEI; density $=3.3 \pm 0.02 \mathrm{~g} / \mathrm{mL}$ ) in glass constriction tubes, inserted into test tubes following the procedure of Dumitru and Stockli (1998). Grains were left to settle within the MEI filled constriction tubes for $\sim 1$ hour. Lighter grains were removed by inserting a needle into the opening of the constriction tube and removing the constriction tube with forceps. The lighter grains were then transferred to filter paper, washed repeatedly with acetone, transferred to a vile and archived. The denser mineral fraction was then transferred to a separate funnel with filter paper, repeatedly washed with acetone, sonicated, washed again, and dried in a low temperature oven. The final dense zircon-rich mineral separate was inspected to assess the proportion of zircon. Those samples found to contain significant amounts of pyrite progressed to further processing. Those samples found to be sufficiently zircon-rich without significant amounts of other dense nonmagnetic mineral grains progressed to sample mounting. 
Pyrite rich samples were placed within glass beakers, warmed over a hot plate and agitated with a magnetic stirrer while submerged in a $20 \%$ nitric acid solution in order to dissolve the pyrite ( $\sim 25 \mathrm{~min})$. Samples were then washed repeatedly, sonicated, dried and transferred to a new vial. The final zircon rich mineral separate progressed to sample mounting steps.

To avoid the biases related to the selection of individual grains, each sample's resulting zircon-rich separate was simply poured onto double-sided tape attached to a hard glass tile within the bounds of a 1" diameter Buehler circular ring form. Any un-adhered grains were then poured off to yield a representative mounted subset. Samples were again visually inspected to ensure that the resulting mounted aliquot was zircon-rich. Obvious grains of non-zircon high-density nonmagnetic minerals (e.g. pyrite, barite, apatite) were removed from the mount by hand using tweezers. Approximately 300 individual zircon grains were mounted in this manner for each sample.

Grain mounts were then constructed using Buehler Epo-Thin epoxy resin and hardener (Buehler \#20-8142-016 \& \#20-8140-032). Epoxy resin was mixed with hardener at a ratio of 100:39 and poured over top the grains within the 1" diameter Buehler ring form and allowed to harden for 48 hours. Mounts were then removed from the glass tile and sanded using progressively finer wet sandpaper - standard 2500 grit paper followed by 9 micron and 5 micron film paper (Precision Surfaces PSI-1609-6 and PSI-1605-6). Sanding progressed until grains were polished between $1 / 3-1 / 2$ way into the surface of most grains without removing the smallest grains. Mounts were inspected under the microscope between each sanding step. When found to be sufficiently well sanded, mounts were finally polished using a solution of 1 micron gamma 
alumina Buehler micropolish B on a Buehler MINIMET auto-polisher, sonicated, dried, and stored in clean sample containers until LA-ICP-MS analysis.

\section{NOTE ON LASER-ABLATION MASS-SPECTROMETRY}

Detrital-zircon U-Pb geochronologic analysis was performed at the University of South Carolina’s Center for Elemental Mass Spectrometry (CEMS) by laser-ablation high-resolution single-collector inductively coupled plasma mass-spectrometry (LA-HR-SC-ICP-MS) in 2 different sample runs during December of 2015 (23DF15 \& 26DF15) and May of 2016 (05DF15, 41DF15, 43DF15 \& J1415).

Grain ablation was conducted using a PhotonMachines Analyte G2 193 nm (deep ultraviolet) ArF exciplex laser operating with a $25 \mu \mathrm{m}$ diameter spot aimed at the center of individual sample zircons, “unknowns,” and reference zircons “standards.” Reference zircon standards come from natural zircons of well-constrained and known ages determined by U-Pb isotope dilution thermal ionizonation mass-spectrometry (ID-TIMS). All zircon grains were mounted in 1” polished epoxy resin-filled ring forms and contained within a nine-hole stage held within a HelEx sample cell. Unknown zircons were randomly selected, shot by the laser and ablated in batches of five unknown grains each. Natural reference "standard” zircons were analyzed after each set of five unknown grains. The method of sequentially shooting five unknowns followed by standards is referred to as the "standard-unknown bracketing" approach and is used to correct for instrumental drift age-offset, and down-hole elemental fractionation as the laser ablates (e.g. Gehrels, 2014). Instrumental drift and down-hole fractionation both introduce uncertainties in age accuracy and precision (e.g. Gehrels, 2014) as compared to data 
collected by ID-TIMS; however, this is offset by the larger datasets used it detrital provenance studies such as this one.

For the purposes is of this study the Sri Lanka (SL) zircon standard was used as the primary reference material $\left(\right.$ TIMS age $=563.5 \pm 2.3 \mathrm{Ma}, 2 \sigma ; 518 \mathrm{ppm} \mathrm{U}, 68 \mathrm{ppm} \mathrm{Th},{ }^{200} \mathrm{~Pb} / 204 \mathrm{~Pb}=$ 18000; Gehrels et al., 2008). The zircon standard 91500 (ID-TIMS age = $1065 \pm 5$ Ma;

Wiedenbeck et al., 1995) was used as the secondary reference material. For consistency and comparability all ages reported are based on the reduction scheme using SL as the primary reference material. During analysis, both reference materials were ablated following ablation of every five unknowns.

Ablated material was transported in He carrier gas flowing from internal and external HelEx sample cell mass flow controllers toward the torch of the mass spectrometer. Entering the mass spectrometer, the carrier gas mixed with Ar sample gas in a mixing chamber before flowing into the dry plasma torch of the Thermo ELEMENT2 high resolution single collector mass spectrometer, where the ablatant passed through the plasma and was ionized. A portion of the ionized material then passed through the sample and skimmer cones into the vacuum of the mass spectrometer where it could be analysed and discriminated using the ELEMENT2's doublefocusing magnetic sector field mass analyzer.

Before each analysis, the entire LA-HR-SC-ICP-MS system was manually adjusted to maximize signal and performance using the NIST 612 synthetic glass standard (Hollocher and Ruiz, 1995). Manual tuning included adjusting the torch position as well as sample and carrier gas flow rates while attempting to minimize oxide formation. Analysis of unknown and reference zircons involved the collection of signal intensity data for a set of masses (202, 204, 206, 207, 208, 232, and 238) using the ion counting feature of the ELEMENT2. The mass of 235 was 
found by dividing the signal intensity of 238 by 137.88 (Nier, 1939 a\&b; Nier et al., 1941). During analysis, laser ablation of "unknown" and "standard" zircons was preceded by 5 seconds of background data collection and followed by approximately 15 seconds for signal washout and data recording. In this manner, between 50 and 75 standard and unknown grains could be measured per hour, including time for periodic manual laser focusing and selection of spot locations.

NOTE ON DETRITAL ZIRCON DATA REDUCTION AND PROCESSING

Processing of the raw data generated by the mass spectrometer was conducted using the UPbGeochronology3 data reduction scheme of the Iolite v.3 software package (Paton et al., 2010) within the IgorPro data and computation package.

Processing began with the import of individual .FIN2 files acquired from analysis of each unknown or reference zircon and its associated baseline and washout signals into the timeconstrained reference frame of the IgorPro environment. Following data import, integration windows for baseline and ablatant signals were selected automatically by trimming $5 \mathrm{sec}$ respectively from the start and end of each data file for baseline integrations, and $15 \mathrm{sec}$ respectively from the start and end of each data file for ablation signals. In addition to removing the baseline signal for the ablatant signal, the latter data trimming removes any surface contamination incorporated into the mount surface during grinding, polishing and storage. Small offsets in analytical start times caused by operator error or computational delays in compiling prior analyses’ data occasionally yielded inaccurately auto-selected integration windows; the ablation of epoxy in insufficiently ground zircons and/or small zircons drilled through during standard ablation durations yielded similarly inappropriate windows. Adjustment of these windows was achieved by manual grain-by-grain data inspection, as was the elimination of 
analyses of grains known not to be zircon (e.g., by very low U signals, etc.). In the case of the former, care was taken to ensure that the start time of each ablatant integration window was spatially equivalent to those of grains with auto-selected windows in order to optimize the accuracy of down-hole fraction correction models.

Following data import, selection, and inspection of integration windows, Iolite-based data reduction involved: (1) subtraction of background signals from an automatic (best-fit: see Paton et al. 2010) interpolation model; (2) determination of an appropriate downhole-fractionation correction model by separately stacking the ${ }^{200} \mathrm{~Pb} / 23 \mathrm{U},{ }^{200} \mathrm{~Pb} / 23 \mathrm{U}$ and ${ }^{2008 \mathrm{~Pb}} / 23 \mathrm{Th}$ downhole ratios for each of the primary reference zircon analyses, calculating best-fit exponential curves to those stacked datasets, and applying the resulting models to transform the isotopic ratios of analyzed ‘unknown’ zircons, ideally to optimize ratio steadiness; (3) estimation and correction of instrumental age-offsets and drift by comparison of determined (raw) and accepted (i.e., IDTIMS) isotopic ratios of the primary reference zircon; and (4) calculation of final ages and values, including (a) propagated uncertainties determined from analyses of the primary reference zircon as pseudo-secondary standards, progressively removing them individually from the dataset, reprocessing the data, and calculating uncertainty, and (b) error correlations using the IgorPro StatsCorrelation function. See Paton et al. (2010) for further clarification and discussion of methods of Iolite data reduction of U-Pb zircon data. 
LIST OF SUPPLEMENTAL DATA TABLES: PRESENTED ON SUBSEQUENT PAGES

Table 1: Sample Collection and Analyses Run

Table 2: Raw Geochemical Data of Apoon Volcanic Rocks

Table 3: Apoon Detrital Zircon U-Pb Data - 05DF15

Table 4: Kayak Detrital Zircon U-Pb Data - 23DF15

Table 5: Beaucoup Detrital Zircon U-Pb Data - J1415

Table 6: Beaucoup Detrital Zircon U-Pb Data - 43DF15

Table 7: Kanayut Detrital Zircon U-Pb Data - 41DF15

Table 8: Hunt Fork Detrital Zircon U-Pb Data - 26DF15 
Table 1: Sample Collection and Analyses Run

All Samples are stored with the Dept. of Geology and Geography at WVU

\begin{tabular}{|c|c|c|c|c|c|c|c|c|c|c|c|c|}
\hline Sample Number & WPF Fieldbook & Collection & Northing & Easting & Elevation & Locale & Lithology & Thin Sectioned & DZ Sep & LA-ICPMS & Powdered & ActLabs \\
\hline 01DF15 & PF002 & $7 / 19 / 2015$ & 591604 & 7530431 & 3324 & Pyramid Creek Area-S & basalt & $\mathrm{Y}$ & & & $\mathrm{Y}$ & $\mathrm{Y}$ \\
\hline 02DF15 & PF004 & $7 / 19 / 2015$ & 591957 & 7530138 & 3635 & Pyramid Creek Area-S & ss & & & & & \\
\hline 03DF15 & PF006 & $7 / 19 / 2015$ & 592251 & 7529975 & - & Pyramid Creek Area-S & metatuff & $Y$ & & & $Y$ & $Y$ \\
\hline 04DF15 & PF011 & $7 / 19 / 2015$ & 593039 & 7529146 & - & Pyramid Creek Area-S & metatuff & $Y$ & & & & \\
\hline 05DF15 & PF012 & $7 / 19 / 2015$ & 593047 & 7529129 & - & Pyramid Creek Area-S & lithic ss & $Y$ & $Y$ & $Y$ & & \\
\hline 06DF15 & PF014 & $7 / 19 / 2015$ & 591784 & 7529758 & - & Pyramid Creek Area-S & tuff & $Y$ & & & $Y$ & \\
\hline 07DF15 & PF015 & $7 / 19 / 2015$ & 590949 & 7530392 & 1901 & Pyramid Creek Area-S & ss & $Y$ & & & & \\
\hline 08DF15 & PF017 & $7 / 20 / 2015$ & 591095 & 7531135 & 1712 & Pyramid Creek Area- $\mathrm{N}$ & basalt & $Y$ & & & $Y$ & $Y$ \\
\hline 09DF15 & PF019 & $7 / 20 / 2015$ & 591467 & 7531140 & 1828 & Pyramid Creek Area-N & basalt & $Y$ & & & $Y$ & \\
\hline 10DF15 & PF021 & $7 / 20 / 2015$ & 592495 & 7531188 & 2105 & Pyramid Creek Area- $\mathrm{N}$ & slate & $Y$ & & & & \\
\hline 11DF15 & PF026 & $7 / 20 / 2015$ & 593242 & 7530575 & 2069 & Pyramid Creek Area- $\mathrm{N}$ & andesite & $\mathrm{Y}$ & & & $Y$ & $Y$ \\
\hline 12DF15 & PF027 & $7 / 20 / 2015$ & 593393 & 7530598 & 2100 & Pyramid Creek Area- $\mathrm{N}$ & ss & $\mathrm{Y}$ & & & & \\
\hline 13DF15 & PF035 & $7 / 21 / 2015$ & 592123 & 7532190 & 3632 & Pyramid Creek Area-N & metabasalt & $Y$ & & & $Y$ & $Y$ \\
\hline 14DF15 & PF037 & $7 / 21 / 2015$ & 592068 & 7532273 & 3584 & Pyramid Creek Area-N & metabasalt & & & & & \\
\hline 15DF15 & PF037 & $7 / 21 / 2015$ & 592068 & 7532273 & 3584 & Pyramid Creek Area- $\mathrm{N}$ & phyllite & & & & & \\
\hline 16 DF15 & PF039 & $7 / 21 / 2015$ & 592286 & 7532571 & 3605 & Pyramid Creek Area-N & andesite & & & & & \\
\hline 17DF15 & PF040 & $7 / 21 / 2015$ & 592291 & 7532648 & 3657 & Pyramid Creek Area-N & andesite & $Y$ & & & $Y$ & \\
\hline 18DF15 & PF043 & $7 / 21 / 2015$ & 592452 & 7533689 & 3810 & Pyramid Creek Area- $\mathrm{N}$ & slate & & & & & \\
\hline 19DF15 & PF044 & $7 / 21 / 2015$ & 592492 & 7533815 & 3768 & Pyramid Creek Area- $\mathrm{N}$ & slate & & & & & \\
\hline 20DF15 & PF052 & $7 / 21 / 2015$ & 592672 & 7532630 & - & Pyramid Creek Area-N & andesite & $Y$ & & & & \\
\hline 21DF15 & PF054 & $7 / 21 / 2015$ & 592618 & 7532385 & - & Pyramid Creek Area-N & andesite & $Y$ & & & $Y$ & Y \\
\hline 22DF15 & PF061 & $7 / 22 / 2015$ & 594157 & 7534481 & 3839 & S of the N. Fork - btw Ernie and Bomb. & ss & $Y$ & & & & \\
\hline 23DF15 & PF062 & $7 / 22 / 2015$ & 594326 & 7534310 & 4265 & S of the N. Fork - btw Ernie and Bomb. & ss & $Y$ & $Y$ & $Y$ & & \\
\hline 24DF15 & PF070 & $7 / 23 / 2015$ & 596421 & 7534790 & 2407 & Bomdardment Creek & andesite & $Y$ & & & $Y$ & $Y$ \\
\hline 25DF15 & PF072 & $7 / 23 / 2015$ & 596874 & 7534364 & 2817 & Bomdardment Creek & andesite & $\mathrm{Y}$ & & & $Y$ & $Y$ \\
\hline 26DF15 & PF075 & $7 / 24 / 2015$ & 593130 & 7537081 & 2481 & $\mathrm{~N}$ of the $\mathrm{N}$ Fork - btw Ernie and Bomb. & ss & $Y$ & $\mathrm{Y}$ & $\mathrm{Y}$ & & \\
\hline 27DF15 & PF076 & $7 / 24 / 2015$ & 593126 & 7537293 & 2797 & $\mathrm{~N}$ of the N Fork - btw Ernie and Bomb. & shale & & & & & \\
\hline 28DF15 & PF084 & $7 / 25 / 2015$ & 590112 & 7534985 & 1699 & N Fork Koyukuk & slate & $\mathrm{Y}$ & & & & \\
\hline 29DF15 & PF085 & $7 / 25 / 2015$ & 590064 & 7534806 & 1670 & N Fork Koyukuk & conglomerate & $Y$ & & & & \\
\hline 30 DF15 & PF092 & $7 / 26 / 2015$ & 587088 & 7526376 & 2983 & Kachawara Creek & phyllite & & & & & \\
\hline 31DF15 & PF093 & $7 / 26 / 2015$ & 586761 & 7526449 & 2532 & Kachawara Creek & andesite & & & & & \\
\hline 32DF15 & PF104 & $7 / 27 / 2015$ & 590601 & 7527188 & 3482 & Boriel Mtn Area & basalt & $Y$ & & & $Y$ & $Y$ \\
\hline 33DF15 & PF107 & $7 / 27 / 2015$ & 590899 & 7526653 & 3577 & Boriel Mtn Area & tuff & $Y$ & & & $Y$ & $Y$ \\
\hline 34DF15 & PF108 & $7 / 27 / 2015$ & 590952 & 7526601 & 3580 & Boriel Mtn Area & phyllite & $Y$ & & & & \\
\hline 35DF15 & PF114 & $7 / 29 / 2015$ & 590915 & 7523411 & 3006 & Boriel Mtn Area & tuff & & & & & \\
\hline $36 \mathrm{DF} 15$ & PF115 & $7 / 29 / 2015$ & 591057 & 7523464 & 3356 & E of $N$ Fork - $N$ of Fishless & tuff & $Y$ & & & & \\
\hline 37DF15 & PF116 & $7 / 29 / 2015$ & 591167 & 7523404 & 3537 & E of $N$ Fork $-N$ of Fishless & ss & & & & & \\
\hline 38DF15 & PF119 & $7 / 29 / 2015$ & 591309 & 7423635 & 3971 & E of $N$ Fork $-\mathrm{N}$ of Fishless & andesite & $Y$ & & & $Y$ & $Y$ \\
\hline $39 D F 15$ & PF124 & $7 / 31 / 2015$ & 588889 & 7535206 & 1823 & Shusaluk Area & shale & & & & & \\
\hline 40DF15 & PF128 & $7 / 31 / 2015$ & 587871 & 7535347 & 3022 & Shusaluk Area & ss & $Y$ & & & & \\
\hline 41DF15 & PF133 & $7 / 31 / 2015$ & 586836 & 7535250 & 4223 & Shusaluk Area & ss & & $Y$ & $Y$ & & \\
\hline 42DF15 & PF159 & $8 / 2 / 2015$ & 586888 & 7532129 & 3592 & Koyukuk & ss & $Y$ & $Y$ & & & \\
\hline 43DF15 & PF160 & $8 / 2 / 2015$ & 586692 & 7531995 & 3143 & Koyukuk & lithic ss & $Y$ & $Y$ & $Y$ & & \\
\hline 44DF15 & PF160 & $8 / 2 / 2015$ & 586692 & 7531995 & 3143 & Koyukuk & lithic ss & $Y$ & & & & \\
\hline 45DF15 & PF166 & $8 / 2 / 2015$ & 587552 & 7532070 & 2946 & Koyukuk & wacke & $Y$ & & & & \\
\hline 46DF15 & PF173 & $8 / 3 / 2015$ & 588426 & 7531505 & 2301 & Frigid Craggs & ss & $Y$ & & & & \\
\hline 47DF15 & PF175 & $8 / 3 / 2015$ & 588350 & 7531230 & 2425 & Frigid Craggs & ss & $Y$ & & & & \\
\hline $\mathrm{J} 1409$ & Strauss & - & $6755^{\prime} 49.8^{\prime \prime}$ & $15028^{\prime} 15.0^{\prime \prime}$ & - & E side of Fenster, Justin & SS & $\mathrm{Y}$ & $Y$ & & & \\
\hline $\mathrm{J} 1415$ & Strauss & - & $6756^{\prime} 19.9^{\prime \prime}$ & $15025^{\prime} 40.2^{\prime \prime}$ & - & E side of Fenster, Justin & conglomerate & $Y$ & $Y$ & $Y$ & & \\
\hline $\mathrm{J} 1417$ & Strauss & - & $6756^{\prime} 08.8^{\prime \prime}$ & $15026^{\prime} 21.9^{\prime \prime}$ & - & E side of Fenster, Justin & ss & $\mathrm{Y}$ & $Y-f$ & & & \\
\hline
\end{tabular}


Table 2: Raw Geochemical Data of Apoon Volcanic Rocks

\begin{tabular}{|c|c|c|c|c|c|c|c|c|c|c|c|c|c|c|}
\hline Analyte & Unit & Det. Limit & Method & $01 D F 15$ & $03 \mathrm{DFI5}$ & $08 \mathrm{DF} / 5$ & $11 \mathrm{DFI5}$ & $13 \mathrm{DFI5}$ & $21 \mathrm{DFI}$ & $24 \mathrm{DF} / 5$ & $25 \mathrm{DFI5}$ & $32 \mathrm{DFI5}$ & 33DFI5 & $38 \mathrm{DFI5}$ \\
\hline Lat $(\mathrm{N})$ & deg & - & - & 67.874 & 67.869704 & 67.880471 & 67.87477 & 67.889606 & 67.891193 & 67.911505 & 67.907531 & 67.845244 & 67.840358 & 67.813177 \\
\hline Long(W) & deg & - & - & -150.820238 & -150.805255 & -150.831753 & -150.781184 & -150.806428 & -150.794473 & -150.701873 & -150.691463 & -150.846776 & -150.840137 & -150.832909 \\
\hline $\mathrm{SiO} 2$ & $\%$ & 0.01 & FUS-ICP & 46.34 & 54.77 & 46.36 & $58.4 \mathrm{I}$ & 54.77 & 50.47 & 51.42 & 48.44 & 49.38 & 57.62 & 48.48 \\
\hline $\mathrm{Al} 2 \mathrm{O}_{3}$ & $\%$ & 0.01 & FUS-ICP & 15.46 & 16.11 & 15.97 & 15.85 & 16.67 & 15.5 & 12.8 & 13.61 & 14 & 15.82 & 16.18 \\
\hline $\mathrm{Fe} 2 \mathrm{O} 3(\mathrm{~T})$ & $\%$ & 0.01 & FUS-ICP & 17.46 & 5.12 & 9.01 & 5.3 & 10.83 & 8.2 & 5.63 & 10.85 & 10.3 & 7.97 & 10.61 \\
\hline $\mathrm{MnO}$ & $\%$ & 0.001 & FUS-ICP & 0.22 & 0.135 & 0.147 & 0.122 & 0.125 & 0.154 & 0.135 & 0.171 & 0.19 & 0.111 & 0.183 \\
\hline $\mathrm{MgO}$ & $\%$ & 0.01 & FUS-ICP & 4.3 & 4.56 & 9.05 & 2.75 & 5.35 & 7.4 & 5.35 & 8.52 & 6.79 & 0.93 & 5.93 \\
\hline $\mathrm{CaO}$ & $\%$ & 0.01 & FUS-ICP & 4.03 & 4.92 & 9.26 & 4.1 & 1.45 & 9.87 & 12.77 & 10.67 & 11.03 & 3.72 & 9.95 \\
\hline $\mathrm{Na} 2 \mathrm{O}$ & $\%$ & 0.01 & FUS-ICP & 3.02 & 4.06 & 3.75 & 5.32 & 3.63 & 2.24 & 1.83 & 3.03 & 3.17 & 6.95 & 3.49 \\
\hline $\mathrm{K} 2 \mathrm{O}$ & $\%$ & 0.01 & FUS-ICP & 0.59 & 1.8 & $<0.01$ & 1.24 & 0.88 & 1.33 & 2.39 & 0.06 & 0.14 & 0.86 & 0.28 \\
\hline $\mathrm{TiO} 2$ & $\%$ & 0.001 & FUS-ICP & 4.177 & 0.602 & 0.794 & 0.606 & 0.742 & 0.635 & 0.566 & 1.401 & 1.362 & 1 & 1.441 \\
\hline P2O5 & $\%$ & 0.01 & FUS-ICP & 0.42 & 0.24 & 0.07 & 0.27 & 0.13 & 0.18 & 0.15 & 0.13 & 0.15 & 0.25 & 0.12 \\
\hline LOI & $\%$ & & FUS-ICP & 4.81 & 7.78 & 6.16 & 6.17 & 5.45 & 4.58 & 7.47 & 3.33 & 2.88 & 3.4 & 3.38 \\
\hline Total & $\%$ & 0.01 & FUS-ICP & 100.8 & 100.1 & 100.6 & 100.1 & 100 & 100.6 & 100.5 & 100.2 & 99.37 & 98.62 & 100.1 \\
\hline Sc & $\mathrm{ppm}$ & 1 & FUS-ICP & 39 & 21 & 33 & $1 \mathrm{II}$ & 33 & 40 & 19 & 39 & 42 & 10 & 38 \\
\hline $\mathrm{Be}$ & $\mathrm{ppm}$ & 1 & FUS-ICP & 1 & $\mathrm{I}$ & $<1$ & 1 & $<1$ & $<1$ & $<1$ & $<1$ & $<1$ & $<1$ & $<1$ \\
\hline $\mathrm{v}$ & $\mathrm{ppm}$ & 5 & FUS-ICP & 386 & 151 & 181 & 101 & 236 & 207 & 151 & 266 & 300 & 14 & 321 \\
\hline $\mathrm{Ba}$ & $\mathrm{ppm}$ & 2 & FUS-ICP & 123 & 407 & 15 & 451 & 156 & 102 & 505 & 32 & 101 & 396 & 151 \\
\hline $\mathrm{Sr}$ & $\mathrm{ppm}$ & 2 & FUS-ICP & 178 & 128 & 121 & 326 & 138 & 101 & 413 & 152 & 138 & 316 & 137 \\
\hline $\mathbf{Y}$ & $\mathrm{ppm}$ & 1 & FUS-ICP & 47 & 17 & 20 & 17 & 14 & 17 & 16 & 28 & 27 & 60 & 27 \\
\hline $\mathrm{Zr}$ & $\mathrm{ppm}$ & 2 & FUS-ICP & 273 & 124 & 40 & 134 & 62 & 56 & 51 & 84 & 91 & 466 & 80 \\
\hline $\mathrm{Cr}$ & $\mathrm{ppm}$ & 20 & FUS-MS & 60 & 110 & 230 & 40 & 70 & 260 & 140 & 360 & 120 & 30 & 100 \\
\hline Co & $\mathrm{ppm}$ & 1 & FUS-MS & 44 & 21 & 42 & 13 & 29 & 33 & 16 & 45 & 34 & 7 & 34 \\
\hline $\mathrm{Ni}$ & $\mathrm{ppm}$ & 20 & FUS-MS & 40 & 40 & 130 & 20 & 40 & 100 & 70 & 190 & 50 & $<20$ & 60 \\
\hline $\mathrm{Cu}$ & $\mathrm{ppm}$ & 10 & FUS-MS & 20 & 50 & 80 & $<10$ & 60 & 60 & 30 & 80 & 20 & $<10$ & 120 \\
\hline$Z_{n}$ & $\mathrm{ppm}$ & 30 & FUS-MS & 130 & 60 & 60 & 60 & 90 & 60 & 50 & 70 & 60 & 80 & 100 \\
\hline $\mathrm{Ga}$ & $\mathrm{ppm}$ & 1 & FUS-MS & 24 & 14 & 12 & 13 & 15 & 12 & 9 & 12 & 14 & 21 & 15 \\
\hline $\mathrm{Ge}$ & $\mathrm{ppm}$ & 1 & FUS-MS & 3 & 2 & 1 & 2 & 1 & 2 & 1 & 2 & 2 & 2 & 2 \\
\hline As & $\mathrm{ppm}$ & 5 & FUS-MS & 13 & $<5$ & $<5$ & $<5$ & 8 & $<5$ & $<5$ & $<5$ & $<5$ & $<5$ & $<5$ \\
\hline $\mathrm{Rb}$ & $\mathrm{ppm}$ & 2 & FUS-MS & 21 & 58 & $<2$ & 49 & 24 & 19 & 52 & $<2$ & 2 & 27 & 6 \\
\hline $\mathrm{Nb}$ & $\mathrm{ppm}$ & 1 & FUS-MS & 17 & 4 & $<1$ & 5 & $\mathrm{I}$ & 2 & 2 & 3 & 4 & 24 & 4 \\
\hline Mo & $\mathrm{ppm}$ & 2 & FUS-MS & $<2$ & $<2$ & $<2$ & $<2$ & $<2$ & $<2$ & $<2$ & $<2$ & $<2$ & 3 & $<2$ \\
\hline $\mathrm{Ag}$ & $\mathrm{ppm}$ & 0.5 & FUS-MS & 0.8 & $<0.5$ & $<0.5$ & $<0.5$ & $<0.5$ & $<0.5$ & $<0.5$ & $<0.5$ & $<0.5$ & 1.3 & $<0.5$ \\
\hline In & $\mathrm{ppm}$ & 0.2 & FUS-MS & $<0.2$ & $<0.2$ & $<0.2$ & $<0.2$ & $<0.2$ & $<0.2$ & $<0.2$ & $<0.2$ & $<0.2$ & $<0.2$ & $<0.2$ \\
\hline$S_{n}$ & $\mathrm{ppm}$ & 1 & FUS-MS & 1 & 1 & $<1$ & $<1$ & $<1$ & 2 & 5 & 1 & 1 & 4 & $<1$ \\
\hline Sb & $\mathrm{ppm}$ & 0.5 & FUS-MS & 0.9 & 0.9 & 0.8 & 1.7 & 1.5 & 0.8 & 0.8 & 0.8 & 0.8 & 1 & 1.6 \\
\hline Cs & $\mathrm{ppm}$ & 0.5 & FUS-MS & 0.7 & 3.2 & $<0.5$ & 3 & 2.1 & 1.3 & 7.1 & 1.1 & $<0.5$ & 23.1 & $<0.5$ \\
\hline $\mathrm{La}$ & $\mathrm{ppm}$ & 0.1 & FUS-MS & 33.6 & 27.2 & 1 & 37.2 & 4.7 & 8 & 7.7 & 3.3 & 4.8 & 37 & 6.4 \\
\hline $\mathrm{Ce}$ & $\mathrm{ppm}$ & 0.1 & FUS-MS & 74.4 & 55.1 & 3.4 & 72.5 & 12.1 & 19.9 & 19.4 & 9.9 & 14 & 86 & 15.5 \\
\hline $\mathrm{Pr}$ & $\mathrm{ppm}$ & 0.05 & FUS-MS & 9.37 & 6.29 & 0.67 & 7.96 & 1.57 & 2.53 & 2.54 & 1.66 & 2.21 & 10.8 & 2.35 \\
\hline $\mathrm{Nd}$ & $\mathrm{ppm}$ & 0.1 & FUS-MS & 40.2 & 24.4 & 4.2 & 30.3 & 6.9 & 11.5 & 11.6 & 9.4 & 11.5 & 45.1 & 11.2 \\
\hline $\mathrm{Sm}$ & $\mathrm{ppm}$ & 0.1 & FUS-MS & 9.8 & 4.9 & 1.7 & 5.6 & 1.9 & 2.9 & 2.8 & 3.5 & 3.9 & 11.6 & 3.4 \\
\hline $\mathrm{Eu}$ & $\mathrm{ppm}$ & 0.05 & FUS-MS & 3.37 & 1.21 & 0.79 & 1.47 & 0.55 & 0.62 & 0.81 & 1.55 & 1.33 & 3.13 & 1.1 \\
\hline Gd & $\mathrm{ppm}$ & 0.1 & FUS-MS & 10 & 4 & 2.9 & 4.2 & 2.3 & 2.8 & 2.8 & 4.5 & 4.7 & 11.6 & 4.4 \\
\hline $\mathrm{Tb}$ & $\mathrm{ppm}$ & 0.1 & FUS-MS & 1.6 & 0.6 & 0.5 & 0.6 & 0.4 & 0.5 & 0.5 & 0.8 & 0.8 & 2 & 0.8 \\
\hline Dy & $\mathrm{ppm}$ & 0.1 & FUS-MS & 9.5 & 3.2 & 3.6 & 3.3 & 2.8 & 3 & 2.9 & 5.4 & 5.3 & 12 & 5.3 \\
\hline $\mathrm{Ho}$ & $\mathrm{ppm}$ & 0.1 & FUS-MS & 1.9 & 0.6 & 0.7 & 0.6 & 0.6 & 0.6 & 0.6 & 1.1 & 1.1 & 2.4 & 1.1 \\
\hline $\mathrm{Er}$ & $\mathrm{ppm}$ & 0.1 & FUS-MS & 5.5 & 1.8 & 2.1 & 1.8 & 1.9 & 1.8 & 1.7 & 3.3 & 3.1 & 7 & 3.2 \\
\hline $\mathrm{Tm}$ & $\mathrm{ppm}$ & 0.05 & FUS-MS & 0.78 & 0.28 & 0.33 & 0.27 & 0.3 & 0.28 & 0.26 & 0.5 & 0.48 & 1.05 & 0.48 \\
\hline $\mathrm{Yb}$ & $\mathrm{ppm}$ & 0.1 & FUS-MS & 5 & 1.8 & 2.1 & 1.8 & 1.9 & 1.8 & 1.7 & 3.2 & 3 & 7.1 & 3 \\
\hline Lu & ppm & 0.01 & FUS-MS & 0.77 & 0.29 & 0.29 & 0.27 & 0.32 & 0.29 & 0.29 & 0.49 & 0.46 & 1.08 & 0.46 \\
\hline $\mathrm{Hf}$ & $\mathrm{ppm}$ & 0.2 & FUS-MS & 6.1 & 2.9 & 1.2 & 3.1 & 1.7 & 1.5 & 1.3 & 2.1 & 2.4 & 9.9 & 2 \\
\hline $\mathrm{Ta}_{\mathrm{a}}$ & $\mathrm{ppm}$ & 0.1 & FUS-MS & 1.3 & 0.3 & $<0.1$ & 0.4 & 0.1 & 0.2 & 0.1 & 0.2 & 0.3 & 1.8 & 0.3 \\
\hline$w$ & $\mathrm{ppm}$ & 1 & FUS-MS & 6 & 3 & 2 & 4 & 3 & 2 & 20 & 2 & 3 & 3 & 3 \\
\hline $\mathrm{TI}$ & $\mathrm{ppm}$ & 0.1 & FUS-MS & 0.1 & 0.3 & $<0.1$ & 0.3 & $<0.1$ & $<0.1$ & 0.2 & $<0.1$ & $<0.1$ & 0.2 & $<0.1$ \\
\hline $\mathrm{Pb}$ & $\mathrm{ppm}$ & 5 & FUS-MS & $<5$ & 14 & $<5$ & 8 & 7 & $<5$ & $<5$ & $<5$ & $<5$ & 6 & $<5$ \\
\hline $\mathrm{Bi}$ & $\mathrm{ppm}$ & 0.4 & FUS-MS & $<0.4$ & $<0.4$ & $<0.4$ & $<0.4$ & $<0.4$ & $<0.4$ & $<0.4$ & $<0.4$ & $<0.4$ & $<0.4$ & $<0.4$ \\
\hline Th & $\mathrm{ppm}$ & 0.1 & FUS-MS & 4.2 & 9.6 & 0.2 & 12.8 & 2 & 1.9 & 1.2 & 0.2 & 0.6 & 7.8 & 1 \\
\hline$u$ & $\mathrm{ppm}$ & 0.1 & FUS-MS & 2.1 & 2.9 & $<0.1$ & 3.8 & 0.8 & 0.7 & 0.4 & $<0.1$ & 0.3 & 2.8 & 0.3 \\
\hline
\end{tabular}


Table 3: Apoon Detrital Zircon U-Pb Data - 05DF15

\begin{tabular}{|c|}
\hline \\
\hline Analysis \\
\hline \\
\hline 05DF15 $\mathrm{n}=99$ \\
\hline X05DF_ 1 \\
\hline X05DF_3 \\
\hline X05DF_4 \\
\hline X050F_8 \\
\hline X05DF_9 \\
\hline X05DF_10 \\
\hline X05DF_11 \\
\hline X05DF_12 \\
\hline X05DF_15 \\
\hline X05DF_16 \\
\hline X05DF_17 \\
\hline X05DF_18 \\
\hline X05DF_19 \\
\hline X05DF_20 \\
\hline X05DF_21 \\
\hline X05DF_22 \\
\hline X05DF_23 \\
\hline X05DF_24 \\
\hline X05DF_25 \\
\hline X05DF_26 \\
\hline X05DF_27 \\
\hline X05DF_28 \\
\hline X05DF_29 \\
\hline X05DF_30 \\
\hline X05DF_31 \\
\hline X05DF_32 \\
\hline X05DF_33 \\
\hline X05DF_34 \\
\hline X05DF_35 \\
\hline X05DF_36 \\
\hline X05DF_37 \\
\hline X05DF_38 \\
\hline X05DF_39 \\
\hline X05DF_40 \\
\hline X05DF_41 \\
\hline X05DF_42 \\
\hline X05DF_43 \\
\hline X05DF_44 \\
\hline X05DF_45 \\
\hline X05DF_46 \\
\hline X05DF_47 \\
\hline X05DF_48 \\
\hline X05DF_49 \\
\hline X05DF_50 \\
\hline X05DF_52 \\
\hline X05DF_53 \\
\hline X05DF_54 \\
\hline X05DF_57 \\
\hline X05DF_59 \\
\hline X05DF_60 \\
\hline X05DF_61 \\
\hline X05DF_62 \\
\hline X05DF_63 \\
\hline X05DF_64 \\
\hline x05DF_65 \\
\hline X05DF_66 \\
\hline X05DF_67 \\
\hline X05DF_69 \\
\hline $\mathrm{X}_{05 \mathrm{DF}_{-} 70}$ \\
\hline Xo5DF_71 \\
\hline X05DF_72 \\
\hline X05DF 73 \\
\hline X05DF_74 \\
\hline X05DF 75 \\
\hline X05DF_77 \\
\hline X05DF_78 \\
\hline X05DF_79 \\
\hline X05DF_80 \\
\hline X05DF_82 \\
\hline X05DF_84 \\
\hline X05DF_85 \\
\hline X05DF_86 \\
\hline X05DF_87 \\
\hline X05DF_89 \\
\hline X05DF_90 \\
\hline X05DF_91 \\
\hline X05DF_92 \\
\hline X05DF_93 \\
\hline X05DF_94 \\
\hline X05DF_95 \\
\hline X05DF_96 \\
\hline X05DF_98 \\
\hline X05DF_99 \\
\hline X05DE_100 \\
\hline XO5DE_101 \\
\hline X05DE_102 \\
\hline X05DF_103 \\
\hline X05DF_104 \\
\hline X05DF_105 \\
\hline X05DE_106 \\
\hline XosDF_107 \\
\hline X05DF_108 \\
\hline X05DE_109 \\
\hline X05DF_110 \\
\hline
\end{tabular}


Table 3: Apoon Detrital Zircon U-Pb Data - 05DF15 cont.

\begin{tabular}{|c|c|c|c|c|c|c|c|c|c|c|c|c|c|c|c|c|c|c|c|}
\hline x05DF_112 & 294 & 5.63 & 0.2005 & 0.013 & $-0.21267 \mid$ & 12.88 & 1.4 & 0.463 & 0.036 & 0.79378 & 2450 & 160 & 2674 & 110 & 2824 & 100 & 2824 & 100 & $87 \%$ \\
\hline X05DF_115 & 262.7 & 3.92 & 0.0562 & 0.0038 & 0.1763 & 0.638 & 0.069 & 0.0821 & 0.0061 & 0.22013 & 509 & 37 & 500 & 43 & 442 & 150 & 509 & 37 & $100 \%$ \\
\hline X05DF_117 & 322 & 1.965 & 0.0602 & 0.0044 & 0.16562 & 0.701 & 0.077 & 0.0856 & 0.0063 & 0.2316 & 529.1 & 38 & 538 & 45 & 584 & 150 & 529.1 & 38 & $100 \%$ \\
\hline X05DF_120 & 80.3 & 7.23 & 0.0636 & 0.0053 & 0.27645 & 0.685 & 0.078 & 0.0783 & 0.006 & 0.054685 & 486 & 36 & 528 & 47 & 680 & 180 & 486 & 36 & $100 \%$ \\
\hline *050F $=2$ & 157 & 3.01 & 0.0747 & 0.0053 & 0.019611 & 2.19 & 0.25 & 0.2083 & 0.016 & 0.275 & 1220 & 83 & 1159 & 64 & 1038 & 150 & 1220 & 83 & 118\% \\
\hline *050F 5 & 177.7 & 3.4 & 0.1127 & 0.0072 & 0.22339 & 5.87 & 0.62 & 0.3805 & 0.029 & 0.4806 & 2077 & 130 & 1952 & 92 & 1834 & 120 & 1834 & 120 & 113\% \\
\hline *050F_ 6 & 17.06 & 0.1676 & 0.524 & 0.04 & 0.25477 & 14.03 & 1.6 & 0.1932 & 0.016 & 0.27952 & 1138 & 84 & 2743 & 100 & 4294 & 110 & 1138 & 84 & 2796 \\
\hline *0505-7 & 507 & 4.4 & 0.079 & 0.0052 & 0.39615 & 2.503 & 0.26 & 0.2268 & 0.017 & 0.455332 & 1317 & 9 & 1270 & 77 & 1158 & 130 & 1317 & 90 & $114 \%$ \\
\hline X050F_13 & 88.1 & 1.204 & 0.1845 & 0.012 & 0.35426 & 14.56 & 1.6 & 0.577 & 0.046 & 0.74422 & 2950 & 180 & 2801 & 97 & 2704 & 100 & 2704 & 100 & 109\% \\
\hline X050F_14 & 170.8 & 5.16 & 0.1886 & 0.012 & 0.50452 & 15.59 & 1.6 & 0.607 & 0.047 & 0.63589 & 3055 & 190 & 2854 & 100 & 2731 & 110 & 2734 & 110 & $112 \%$ \\
\hline X05DF_51 & 35.2 & 0.317 & 0.827 & 0.052 & 0.042138 & 398 & 48 & 3.53 & 0.33 & 0.90819 & 9670 & 470 & 6087 & 120 & 5023 & 120 & 5023 & 120 & 193\% \\
\hline xo5DE_55 & 378 & 2.67 & 0.114 & 0.0071 & 0.053439 & 5.7 & 0.62 & 0.364 & 0.029 & 0.77183 & 1998 & 130 & 1926 & 93 & 1860 & 110 & 1860 & 110 & $107 \%$ \\
\hline X050F_56 & 18.9 & 1.16 & 0.1817 & 0.013 & 0.1374 & 16.47 & 1.9 & 0.662 & 0.054 & 0.2983 & 3270 & 210 & 2877 & 100 & 2631 & 81 & 2634 & 81 & $124 \%$ \\
\hline X05DF_58 & 45.6 & 0.464 & 0.792 & 0.048 & 0.30194 & 76.7 & 8 & 0.703 & 0.055 & 0.75454 & 3426 & 210 & 4416 & 100 & 4944 & 110 & 4944 & 110 & $69 \%$ \\
\hline X050F_68 & 409 & 6.58 & 0.1159 & 0.0076 & 0.41626 & 6.01 & 0.64 & 0.374 & 0.029 & 0.43624 & 2055 & 130 & 1973 & 92 & 1894 & 120 & 1894 & 120 & 109\% \\
\hline$\times 050 F_{Z} 76$ & 46.2 & 0.434 & 0.81 & 0.049 & 0.059552 & 65.4 & 8.6 & 0.588 & 0.065 & 0.96007 & 2950 & 270 & 4225 & 140 & 4985 & 110 & 4985 & 110 & $59 \%$ \\
\hline X050F_8 81 & 209.6 & 2.83 & 0.0738 & 0.0047 & 0.3315 & 1.958 & 0.2 & 0.1933 & 0.015 & 0.56434 & 1139 & 80 & 1099 & 70 & 1038 & 130 & 1139 & 80 & 110\% \\
\hline X050F_83 & 35.8 & 0.384 & 0.809 & 0.049 & 0.24636 & 76.2 & 8 & 0.684 & 0.053 & 0.72601 & 3371 & 200 & 4409 & 110 & 4984 & 110 & 4984 & 110 & $68 \%$ \\
\hline X050F_88 & 221 & 2.24 & 0.0991 & 0.0066 & 0.42888 & 4.16 & 0.44 & 0.3058 & 0.023 & 0.29455 & 1719 & 120 & 1663 & 84 & 1594 & 120 & 1594 & 120 & 108\% \\
\hline X05DF_97 & 100 & 1.385 & 0.1873 & 0.012 & 0.4714 & 14.81 & 1.5 & 0.57 & 0.043 & 0.55466 & 2920 & 190 & 2801 & 97 & 2721 & 99 & 2721 & 99 & 107\% \\
\hline XOSDF_113 & 258 & 3.56 & 0.1052 & 0.0063 & 0.19539 & 4.87 & 0.5 & 0.3366 & 0.025 & 0.68726 & 1869 & 120 & 1805 & 86 & 1714 & 110 & 17714 & 110 & 109\% \\
\hline Xo50F_114 & 247 & 4.08 & 0.2149 & 0.013 & 0.14573 & 20.57 & 2.2 & 0.695 & 0.052 & 0.59729 & 3398 & 200 & 3115 & 100 & 2938 & 100 & 2938 & 100 & 116\% \\
\hline X050__116 & 204 & 2.79 & 0.0733 & 0.0046 & 0.1174 & 1.829 & 0.19 & 0.1817 & 0.014 & 0.6466 & 1076 & 75 & 1054 & 69 & 1013 & 130 & 1076 & 75 & $106 \%$ \\
\hline XOSDF_118 & 125 & 3.11 & 0.0764 & 0.0049 & 0.15388 & 2.207 & 0.23 & 0.2112 & 0.016 & 0.50344 & 1235 & 84 & 1181 & 73 & 1096 & 130 & 1235 & 84 & 113\% \\
\hline Xosor_119 & 119.3 & 2.417 & 0.0767 & 0.0049 & 0.35247 & 2.178 & 0.23 & 0.2071 & 0.016 & 0.60941 & 1213 & 86 & 1172 & 73 & 1104 & 120 & 1213 & 86 & $110 \%$ \\
\hline X050__221 & 23.9 & 1.11 & 0.1873 & 0.012 & 0.22831 & 15.03 & 1.6 & 0.582 & 0.045 & 0.52084 & 2955 & 180 & 2812 & 100 & 2708 & 110 & 2708 & 110 & 109\% \\
\hline
\end{tabular}


Table 4: Kayak Detrital Zircon U-Pb Data - 23DF15

\begin{tabular}{|c|}
\hline \\
\hline Analysis \\
\hline Analysis \\
\hline 23DF15 $n=106$ \\
\hline WPF23_2 \\
\hline WPF 23__3 \\
\hline WPF23_4 \\
\hline WPF 23_5 \\
\hline WPF23_6 \\
\hline WPF23_7 \\
\hline WPF 23_\& \\
\hline WPF23_9 \\
\hline WPF23_11 \\
\hline WPF23_12 \\
\hline WPF23_15 \\
\hline WPF23_17 \\
\hline WPF23_18 \\
\hline WPF23_19 \\
\hline WPF23_20 \\
\hline WPF23_21 \\
\hline WPF23_23 \\
\hline WPF23_24 \\
\hline WPF23_25 \\
\hline WPF23_26 \\
\hline WPF23_27 \\
\hline WPF23_28 \\
\hline WPF23_29 \\
\hline WPF23_30 \\
\hline WPF23_31 \\
\hline WPF23_32 \\
\hline WPF23_33 \\
\hline WPF23_34 \\
\hline WPF23_35 \\
\hline WPF23_36 \\
\hline WPF23_37 \\
\hline WPF23_38 \\
\hline WPF23_39 \\
\hline WPF23_40 \\
\hline WPF23_41 \\
\hline WPF23_42 \\
\hline WPF23_43 \\
\hline WPF23_44 \\
\hline WPF23_45 \\
\hline WPF23_46 \\
\hline WPF23_47 \\
\hline WPF23_48 \\
\hline WPF23_49 \\
\hline WPF23_50 \\
\hline WPF23_51 \\
\hline WPF23_52 \\
\hline WPF23_53 \\
\hline WPF23_55 \\
\hline WPF23_56 \\
\hline WPF23_57 \\
\hline WPF23_58 \\
\hline WPF23_59 \\
\hline WPF23_60 \\
\hline WPF23_61 \\
\hline WPF23_62 \\
\hline WPF23_63 \\
\hline WPF23_64 \\
\hline WPF23_65 \\
\hline WPF23_66 \\
\hline WPF23_67 \\
\hline WPF23_68 \\
\hline WPF23_69 \\
\hline WPF23_70 \\
\hline WPF23_71 \\
\hline WPF23_72 \\
\hline WPF23_73 \\
\hline WPF23_74 \\
\hline WPF23_75 \\
\hline WPF23_76 \\
\hline WPF23_77 \\
\hline WPF23_78 \\
\hline WPF23_79 \\
\hline WPF23_82 \\
\hline WPF23_83 \\
\hline WPF23_84 \\
\hline WPF23_85 \\
\hline WPF23_86 \\
\hline WPF23_87 \\
\hline WPF23_88 \\
\hline WPF23_89 \\
\hline WPF23_90 \\
\hline WPF23_91 \\
\hline WPF23_92 \\
\hline WPF23_93 \\
\hline WPF23_94 \\
\hline WPF23_95 \\
\hline WPF23_96 \\
\hline WPF23_97 \\
\hline WPF23.98 \\
\hline WPF23_101 \\
\hline WPF23_102 \\
\hline WPF23_104 \\
\hline WPF23_105 \\
\hline WPF23_107 \\
\hline
\end{tabular}


Table 4: Kayak Detrital Zircon U-Pb Data - 23DF15 - cont.

\begin{tabular}{|c|c|c|c|c|c|c|c|c|c|c|c|c|c|c|c|c|c|c|c|c|}
\hline WPF23_109 & 395 & 1.8 & 0.0619 & 0.0026 & -0.0143499 & 0.564 & 0.038 & 0.066 & 0.0036 & 0.81686 & 412 & 22 & 452 & 24 & 677 & 89 & 412 & 22 & $100 \%$ & 1 \\
\hline WPF23_110 & 172 & 1.64 & 0.1281 & 0.0033 & 0.049426 & 6.79 & 0.49 & 0.387 & 0.026 & 0.92727 & 2100 & 120 & 2076 & 64 & 2065 & 45 & 2065 & 45 & $102 \%$ & 1 \\
\hline WPF23_112 & 211 & 1.02 & 0.1231 & 0.0032 & 0.32761 & 5.18 & 0.29 & 0.308 & 0.019 & 0.91612 & 1726 & 92 & 1847 & 50 & 1995 & 46 & 1995 & 46 & $87 \%$ & 1 \\
\hline WPF23_113 & 79.6 & 1.93 & 0.1016 & 0.003 & 0.023787 & 3.62 & 0.23 & 0.266 & 0.017 & 0.88148 & 1516 & 87 & 1562 & 54 & 1644 & 54 & 1644 & 54 & $92 \%$ & 1 \\
\hline WPF23_114 & 81.6 & 5.87 & 0.0647 & 0.0032 & 0.017043 & 0.642 & 0.064 & 0.0713 & 0.0053 & 0.8591 & 443 & 32 & 497 & 39 & 750 & 100 & 443 & 32 & $100 \%$ & 1 \\
\hline WPF23_115 & 729 & 4.06 & 0.0583 & 0.0021 & 0.29759 & 0.57 & 0.033 & 0.0711 & 0.004 & 0.81505 & 442 & 24 & 456 & 21 & 523 & 77 & 442 & 24 & $100 \%$ & 1 \\
\hline WPF23_116 & 327 & 3.71 & 0.0554 & 0.0018 & -0.094379 & 0.525 & 0.043 & 0.0686 & 0.0047 & 0.93477 & 427 & 28 & 425 & 28 & 436 & 73 & 427 & 28 & $100 \%$ & 1 \\
\hline WPF23_117 & 969 & 5.06 & 0.0555 & 0.0018 & 0.33532 & 0.548 & 0.033 & 0.0709 & 0.0041 & 0.8234 & 441 & 25 & 442 & 22 & 435 & 68 & 441 & 25 & $100 \%$ & 1 \\
\hline WPF23_118 & 543 & 3.05 & 0.0591 & 0.0019 & -0.070981 & 0.596 & 0.034 & 0.0722 & 0.0031 & 0.82298 & 449 & 19 & 473 & 21 & 570 & 72 & 449 & 19 & $100 \%$ & 1 \\
\hline WPF23_119 & 375 & 5.02 & 0.0558 & 0.0023 & 0.058222 & 0.495 & 0.04 & 0.0648 & 0.0047 & 0.871 & 404 & 28 & 405 & 26 & 422 & 87 & 404 & 28 & $100 \%$ & 1 \\
\hline WPF23_120 & 212 & 3.19 & 0.1761 & 0.004 & \begin{tabular}{ll|}
0.093173 &
\end{tabular} & 11.58 & 0.47 & 0.476 & 0.017 & 0.80657 & 2507 & 74 & 2577 & 38 & 2619 & 36 & 2619 & 36 & $96 \%$ & 1 \\
\hline WPF23_1 & 99 & 6.6 & 0.056 & 0.0034 & -0.025753 & 0.529 & 0.069 & 0.0697 & 0.0078 & 0.93242 & 433 & 47 & 422 & 44 & 410 & 130 & 433 & 47 & $100 \%$ & 0 \\
\hline WPF23_10 & 84 & 5.3 & 0.065 & 0.0064 & 0.12259 & 0.71 & 0.1 & 0.075 & 0.0098 & 0.82575 & 464 & 58 & 526 & 61 & 660 & 200 & 464 & 58 & $100 \%$ & 0 \\
\hline WPF23_13 & 179 & 4.72 & 0.0541 & 0.0035 & -0.081701 & 0.564 & 0.086 & 0.0718 & 0.0079 & 0.89551 & 446 & 47 & 442 & 52 & 390 & 120 & 446 & 47 & $100 \%$ & 0 \\
\hline WPF23_14 & 390 & 2.55 & 0.0536 & 0.0026 & -0.026477 & 0.536 & 0.059 & 0.075 & 0.0078 & 0.83533 & 464 & 47 & 430 & 38 & 340 & 110 & 464 & 47 & $100 \%$ & 0 \\
\hline WPF23_16 & 51.3 & 3.33 & 0.0586 & 0.0035 & 0.1361 & 0.86 & 0.11 & 0.104 & 0.011 & 0.87914 & 633 & 65 & 628 & 59 & 510 & 130 & 633 & 65 & $100 \%$ & 0 \\
\hline WPF23_22 & 146.4 & 3.06 & 0.0848 & 0.0023 & 0.26764 & 2.83 & 0.13 & 0.242 & 0.012 & 0.80758 & 1397 & 63 & 1364 & 33 & 1303 & 51 & 1397 & 63 & $107 \%$ & 0 \\
\hline WPF23_54 & 470 & 13.9 & 0.0757 & 0.0016 & 0.32062 & 2.18 & 0.1 & 0.208 & 0.0099 & 0.89032 & 1216 & 52 & 1170 & 32 & 1082 & 43 & 1216 & 52 & $112 \%$ & 0 \\
\hline WPF23_80 & 142 & 1.28 & 0.1187 & 0.0045 & 0.096592 & 3.21 & 0.25 & 0.194 & 0.014 & 0.85077 & 1141 & 76 & 1447 & 61 & 1927 & 68 & 1141 & 76 & $59 \%$ & 0 \\
\hline WPF23_81 & 683 & 5.01 & 0.0719 & 0.0031 & -0.11317 & 1.91 & 0.21 & 0.185 & 0.018 & 0.90793 & 1087 & 95 & 1061 & 73 & 978 & 88 & 1087 & 95 & $111 \%$ & 0 \\
\hline WPF23_99 & 363 & 3.78 & 0.1068 & 0.0019 & 0.058491 & 5.13 & 0.34 & 0.347 & 0.022 & 0.94261 & 1910 & 100 & 1835 & 56 & 1741 & 33 & 1741 & 33 & $110 \%$ & 0 \\
\hline WPF23_100 & 132 & 4.94 & 0.0677 & 0.0032 & 0.056896 & 0.78 & 0.11 & 0.082 & 0.01 & 0.9233 & 505 & 59 & 573 & 56 & 832 & 96 & 505 & 59 & $100 \%$ & 0 \\
\hline WPF23_103 & 3.8 & 1.06 & 0.699 & 0.068 & 0.12622 & 46.6 & 8.5 & 0.47 & 0.09 & 0.913 & 2400 & 360 & 3790 & 180 & 4720 & 160 & 4720 & 160 & $51 \%$ & 0 \\
\hline WPF23_106 & 105 & 2 & 0.1082 & 0.0045 & 0.063086 & 2.89 & 0.32 & 0.183 & 0.018 & 0.90861 & 1080 & 100 & 1363 & 86 & 1770 & 79 & 1080 & 100 & $61 \%$ & 0 \\
\hline WPF23_111 & 3.66 & 4.24 & 0.737 & 0.081 & 0.19629 & 32.3 & 7.9 & 0.313 & 0.062 & 0.89387 & 1700 & 290 & 3390 & 210 & 4810 & 190 & 4810 & 190 & $35 \%$ & 0 \\
\hline
\end{tabular}


Table 5: Beaucoup Detrital Zircon U-Pb Data - J1415

\begin{tabular}{|c|}
\hline \\
\hline Analysis \\
\hline Analysis \\
\hline J1415 $n=122 / 1$ \\
\hline J1415_1 \\
\hline J1415_2 2 \\
\hline J1415_5 \\
\hline J1415_6 \\
\hline J1415_ 7 \\
\hline J1415_8 \\
\hline J1415_9 \\
\hline J1415_10 \\
\hline J1415_11 \\
\hline J1415_12 \\
\hline J1415_13 \\
\hline J1415_14 \\
\hline J1415_15 \\
\hline J1415_16 \\
\hline J1415_18 \\
\hline J1415_19 \\
\hline J1415_20 \\
\hline J1415_21 \\
\hline J1415_23 \\
\hline J1415_24 \\
\hline J1415_25 \\
\hline J1415_26 \\
\hline J1415_27 \\
\hline J1415_28 \\
\hline J1415_29 \\
\hline J1415_30 \\
\hline J1415_31 \\
\hline J1415_32 \\
\hline J1415_33 \\
\hline J1415_34 \\
\hline J1415_35 \\
\hline J1415_36 \\
\hline J1415_37 \\
\hline${ }^{J 1415} 388$ \\
\hline J1415_39 \\
\hline J1415_41 \\
\hline J1415_42 \\
\hline J1415_43 \\
\hline J1415_44 \\
\hline J1415_45 \\
\hline J1415_46 \\
\hline J1415_47 \\
\hline J1415_48 \\
\hline J1415_49 \\
\hline J1415_50 \\
\hline J1415_52 \\
\hline J1415_53 \\
\hline J1415_54 \\
\hline J1415_55 \\
\hline J1415_56 \\
\hline J1415_57 \\
\hline J1415_58 \\
\hline J1415_59 \\
\hline J1415_60 \\
\hline J1415_61 \\
\hline J1415_62 \\
\hline J1415_63 \\
\hline J1415_64 \\
\hline J1415_65 \\
\hline J1415_66 \\
\hline J1415_67 \\
\hline J1415_68 \\
\hline J1415_69 \\
\hline J1415_70 \\
\hline J1415_71 \\
\hline J1415_73 \\
\hline J1415_74 \\
\hline J1415_75 \\
\hline J1415_76 \\
\hline 11415_77 \\
\hline 11415_78 \\
\hline J1415_79 \\
\hline J1415_80 \\
\hline J1415_81 \\
\hline J1415_82 \\
\hline J1415_83 \\
\hline J1415_84 \\
\hline J1415_85 \\
\hline J1415_86 \\
\hline J1415_87 \\
\hline J1415_88 \\
\hline J1415_89 \\
\hline J1415_90 \\
\hline J1415_91 \\
\hline J1415_92 \\
\hline J1415_93 \\
\hline J1415_94 \\
\hline J1415_95 \\
\hline J1415_96 \\
\hline J1415_97 \\
\hline 11415_98 \\
\hline J1415_99 \\
\hline J1415_100 \\
\hline J1415_101 \\
\hline
\end{tabular}


Table 5: Beaucoup Detrital Zircon U-Pb Data - J1415 - cont.

\begin{tabular}{|c|c|c|c|c|c|c|c|c|c|c|c|c|c|c|c|c|c|c|c|c|}
\hline J1415_103 | & 69 & 4.83 & 0.0581 & 0.0041 & 0.21021 & 0.533 & 0.046 & 0.0676 & 0.0034 & 0.042175 & 421.4 & 20 & 431 & 30 & 480 & 140 & 421.4 & 20 & $100 \%$ & 1 \\
\hline J1415_104 & 103.1 & 3.1 & 0.0586 & 0.0039 & 0.27985 & 0.564 & 0.043 & 0.0716 & 0.0036 & 0.15299 & 446 & 22 & 452 & 28 & 500 & 140 & 446 & 22 & $100 \%$ & 1 \\
\hline J1415_105 & 550 & 2.53 & 0.0562 & 0.0018 & 0.38862 & 0.46 & 0.027 & 0.0601 & 0.0031 & 0.50579 & 376.4 & 19 & 383.7 & 19 & 463 & 68 & 376.4 & 19 & $100 \%$ & 1 \\
\hline J1415_106 & 342.1 & 2.38 & 0.1089 & 0.0035 & -0.026189 & 4.59 & 0.3 & 0.3054 & 0.015 & 0.66555 & 1717 & 76 & 1748 & 53 & 1774 & 57 & 1774 & 57 & $97 \%$ & 1 \\
\hline J1415_107 & 291 & 1.171 & 0.0548 & 0.0024 & 0.20008 & 0.459 & 0.033 & 0.0616 & 0.0035 & 0.62408 & 385 & 21 & 383 & 23 & 438 & 100 & 385 & 21 & $100 \%$ & 1 \\
\hline J1415_108 & 166 & 3.97 & 0.0766 & 0.0025 & 0.50171 & 1.876 & 0.11 & 0.1801 & 0.0095 & 0.60825 & 1067 & 52 & 1071 & 40 & 1100 & 64 & 1067 & 52 & $97 \%$ & 1 \\
\hline J1415_109 & 203 & 3.74 & 0.0533 & 0.0024 & 0.4682 & 0.536 & 0.036 & 0.0716 & 0.004 & 0.39348 & 446 & 24 & 434 & 24 & 320 & 96 & 446 & 24 & $100 \%$ & 1 \\
\hline J1415_110 & 59.8 & 4.78 & 0.0531 & 0.0031 & 0.1829 & 0.538 & 0.043 & 0.0707 & 0.0039 & 0.33752 & 440 & 23 & 435 & 29 & 300 & 120 & 440 & 23 & $100 \%$ & 1 \\
\hline J1415_111 & 75 & 2.83 & 0.0775 & 0.0023 & 0.23147 & 1.909 & 0.12 & 0.1771 & 0.0088 & 0.51911 & 1051 & 48 & 1082 & 40 & 1126 & 59 & 1051 & 48 & $93 \%$ & 1 \\
\hline J1415_113 & 452 & 1.385 & 0.0555 & 0.0017 & 0.41991 & 0.499 & 0.028 & 0.0653 & 0.0033 & 0.39604 & 408 & 20 & 411.1 & 19 & 421 & 67 & 408 & 20 & $100 \%$ & 1 \\
\hline J1415_114 & 34.7 & 2.14 & 0.1825 & 0.006 & 0.27623 & 13.01 & 0.8 & 0.522 & 0.029 & 0.69256 & 2706 & 120 & 2682 & 60 & 2668 & 54 & 2668 & 54 & $101 \%$ & 1 \\
\hline J1415_115 & 96.8 & 3.77 & 0.0714 & 0.0043 & 0.070408 & 0.702 & 0.061 & 0.0702 & 0.0037 & 0.45251 & 437 & 23 & 536 & 36 & 990 & 120 & 437 & 23 & $100 \%$ & 1 \\
\hline J1415_116 & 103.1. & 1.684 & 0.1826 & 0.0063 & 0.39594 & 13.5 & 0.83 & 0.531 & 0.028 & 0.53021 & 2744 & 120 & 2711 & 58 & 2668 & 57 & 2668 & 57 & $103 \%$ & 1 \\
\hline$J 1415 \_117$ & 173 & 10.25 & 0.0568 & 0.0021 & -0.11373 & 0.546 & 0.036 & 0.0698 & 0.0034 & 0.58268 & 435 & 21 & 442 & 24 & 479 & 85 & 435 & 21 & $100 \%$ & 1 \\
\hline J1415_118 & 12.46 & 2.06 & 0.1122 & 0.0059 & 0.3481 & 5.08 & 0.35 & 0.3339 & 0.017 & 0.29388 & 1856 & 84 & 1825 & 59 & 1824 & 92 & 1824 & 92 & $102 \%$ & 1 \\
\hline J1415_119 & 161.5 & 1.014 & 0.102 & 0.003 & 0.32089 & 4.09 & 0.24 & 0.2934 & 0.015 & 0.61924 & 1658 & 75 & 1655 & 46 & 1654 & 55 & 1654 & 55 & $100 \%$ & 1 \\
\hline J1415_120 & 107.4 & 2.39 & 0.0573 & 0.0024 & 0.31989 & 0.524 & 0.034 & 0.0666 & 0.0034 & 0.43407 & 416 & 21 & 427 & 23 & 497 & 97 & 416 & 21 & $100 \%$ & 1 \\
\hline J1415_121 & 128 & 4.86 & 0.099 & 0.018 & -0.48413 & 1.1 & 0.24 & 0.075 & 0.0044 & 0.75284 & 466 & 26 & 706 & 100 & 1380 & 310 & 466 & 26 & $100 \%$ & 1 \\
\hline J1415_122 & 94.5 & 4.99 & 0.0768 & 0.0029 & 0.23457 & 1.521 & 0.1 & 0.1434 & 0.0073 & 0.35015 & 864 & 41 & 945 & 37 & 1116 & 80 & 864 & ${ }_{41}$ & $77 \%$ & 1 \\
\hline J1415_123 & 341 & 3.87 & 0.0909 & 0.0024 & 0.43581 & 3.142 & 0.19 & 0.2509 & 0.014 & 0.70831 & 1442 & 70 & 1441 & 46 & 1457 & 55 & 1457 & 55 & $99 \%$ & 1 \\
\hline J1415_124 & 89.4 & 3.1 & 0.0863 & 0.0029 & 0.14227 & 2.758 & 0.17 & 0.2308 & 0.013 & 0.59845 & 1345 & 69 & 1342 & 45 & 1347 & 62 & 1345 & 69 & $100 \%$ & 1 \\
\hline J1415_125 & 127.3 & 3.87 & 0.0599 & 0.0032 & 0.32635 & 0.585 & 0.041 & 0.0706 & 0.0037 & 0.21075 & 440 & 22 & 466 & 27 & 590 & 120 & 440 & 22 & $100 \%$ & 1 \\
\hline J1415_126 & 246 & 1.799 & 0.0598 & 0.0027 & 0.080516 & 0.543 & 0.04 & 0.0665 & 0.0035 & 0.45687 & 415 & 21 & 439 & 26 & 570 & 100 & 415 & 21 & $100 \%$ & 1 \\
\hline J1415_127 & 142.8 & 3.84 & 0.059 & 0.0032 & 0.27245 & 0.555 & 0.039 & 0.068 & 0.0036 & 0.2167 & 424 & 22 & 447 & 25 & 560 & 130 & 424 & 22 & $100 \%$ & 1 \\
\hline J1415_128 & 63.4 & 3.33 & 0.0627 & 0.0044 & 0.013803 & 0.595 & 0.057 & 0.07 & 0.0045 & 0.38588 & 436 & 27 & 470 & 36 & 640 & 140 & 436 & 27 & $100 \%$ & 1 \\
\hline J1415_129 & 133.3 & 2.75 & 0.0583 & 0.0027 & 0.16085 & 0.513 & 0.036 & 0.063 & 0.0031 & 0.22112 & 393.5 & 19 & 419 & 24 & 540 & 110 & 393.5 & 19 & $100 \%$ & 1 \\
\hline J1415_130 & 180 & 2.57 & 0.0555 & 0.0022 & 0.10493 & 0.547 & 0.04 & 0.0703 & 0.004 & 0.49122 & 438 & 24 & 441 & 26 & 414 & 88 & 438 & 24 & $100 \%$ & 1 \\
\hline 11415_3 & 200 & 6 & 0.0864 & 0.0023 & 0.2194 & 2.989 & 0.18 & 0.2477 & 0.012 & 0.39865 & 1426 & 64 & 1402 & 45 & 1343 & 50 & 1343 & 50 & $106 \%$ & $\theta$ \\
\hline 12115_4 & 49.4 & 1.505 & 0.0824 & 0.0028 & 0.40875 & 2.812 & 0.16 & 0.245 & 0.013 & 0.41507 & 1412 & 65 & 1357 & 44 & 1257 & 63 & 1257 & 63 & $112 \%$ & $\theta$ \\
\hline 11415_17 & 3.13 & 0.654 & 0.666 & 0.026 & 0.14107 & 38.3 & 3.6 & 0.418 & 0.036 & 0.90556 & 2230 & 170 & 3777 & 83 & 4669 & 64 & 4669 & 61 & $48 \%$ & $\theta$ \\
\hline 11415_22 & 36.2 & 2.35 & 0.0228 & 0.0043 & 0.082318 & 1.619 & 0.12 & 0.144 & 0.0069 & 0.25488 & 867 & 39 & 973 & 46 & 1260 & 94 & 867 & 39 & $6 \%$ & $\theta$ \\
\hline 11415_40 & 554 & 3.89 & 0.0899 & 0.0026 & 0.24799 & 3.188 & 0.18 & 0.2605 & 0.013 & 0.55915 & 1492 & 67 & 1452 & 45 & 1416 & 55 & 1416 & 55 & $105 \%$ & $\theta$ \\
\hline 11415_51 & 38.8 & 1.047 & 0.768 & 0.02 & 0.15007 & 60.3 & 4.2 & 0.575 & 0.037 & 0.85451 & 2920 & 150 & 41771 & 70 & 4890 & 45 & 4890 & 45 & $60 \%$ & $\theta$ \\
\hline 11415 72 & 580 & 14.9 & 0.0706 & 0.002 & 0.18081 & 1.639 & 0.1 & 0.1698 & 0.0086 & 0.66167 & 1011 & 47 & 984 & 38 & 955 & 58 & 1011 & 47 & $106 \%$ & $\theta$ \\
\hline |1145_112 & 62.9 & 1.036 & 0.622 & 0.019 & 0.38444 | & 16.9 & 099 & 0.1992 & 0.01 & 0.55564 & 1170 & 55 & 2931 & 53 & 4557 & ${ }_{45}$ & 1170 & 55 & $26 \%$ & $\theta$ \\
\hline
\end{tabular}


Table 6: Beaucoup Detrital Zircon U-Pb Data - 43DF15

\begin{tabular}{|c|}
\hline \\
\hline Analysis \\
\hline Analysis \\
\hline 43DF15 $n=126$ \\
\hline X43DF_1 \\
\hline X43DF_2 \\
\hline $\mathrm{X}_{43 \mathrm{DF}-3}$ \\
\hline X43DF_4 \\
\hline $\mathrm{X}_{43 \mathrm{DF}-5}$ \\
\hline X430F_6 \\
\hline $\mathrm{X} 43 \mathrm{DOF}=7$ \\
\hline X430F_- 8 \\
\hline X430F_9 \\
\hline X43DF_11 \\
\hline X430F_12 \\
\hline X43DF_13 \\
\hline X43DF_14 \\
\hline X43DF_15 \\
\hline X43DF_16 \\
\hline X43DF_17 \\
\hline X43DF_18 \\
\hline X43DF_19 \\
\hline X43DF_20 \\
\hline X430F_21 \\
\hline X430F_22 \\
\hline X43DF_23 \\
\hline X430F_24 \\
\hline X43DF_25 \\
\hline X430F_26 \\
\hline X43DF_27 \\
\hline X430F_28 \\
\hline X43DF_29 \\
\hline X43DF_30 \\
\hline X43DF_31 \\
\hline X43DF_-32 \\
\hline X430F_33 \\
\hline X43DF_34 \\
\hline X43DF_ 35 \\
\hline X430F_-36 \\
\hline X43DF_37 \\
\hline X430F_ 38 \\
\hline X43DF_39 \\
\hline X43DF_40 \\
\hline X43DF_41 \\
\hline X43DF_42 \\
\hline X43DF_43 \\
\hline X43DF_44 \\
\hline X43DF_45 \\
\hline X43DF_46 \\
\hline X43DF_47 \\
\hline X430F_48 \\
\hline X43DF_49 \\
\hline $\mathrm{X}_{43 \mathrm{DO}} 50$ \\
\hline X43DF_51 \\
\hline X430F_52 \\
\hline X43DF_53 \\
\hline X43DF_54 \\
\hline X43DF_55 \\
\hline X43DF_56 \\
\hline X430F_57 \\
\hline X43DF_58 \\
\hline X430F_59 \\
\hline X43DF_60 \\
\hline X43DF_61 \\
\hline X43DF_62 \\
\hline X43DF_63 \\
\hline X43DF_64 \\
\hline X43DF_65 \\
\hline X43DF_66 \\
\hline X43DF_67 \\
\hline X43DF_68 \\
\hline X43DF_69 \\
\hline X43DF_70 \\
\hline $\mathrm{X} 43 \mathrm{DF} \mathrm{F}_{-} 71$ \\
\hline X430F_ 72 \\
\hline X430F 73 \\
\hline X43DF_ 74 \\
\hline X430F_75 \\
\hline X43DF_77 \\
\hline X430F_78 \\
\hline X43DF_79 \\
\hline X43DF_80 \\
\hline X43DF_81 \\
\hline X43DF_82 \\
\hline X43DF_83 \\
\hline X43DF_84 \\
\hline X43DF_85 \\
\hline X43DF_86 \\
\hline X43DF_87 \\
\hline X43DF_88 \\
\hline X43DF_89 \\
\hline X43DF_90 \\
\hline X43DF_91 \\
\hline X43DF_92 \\
\hline $\mathrm{X}_{43 \mathrm{DF}} 93$ \\
\hline X43DF_94 \\
\hline X430F_95 \\
\hline X43DF_96 \\
\hline
\end{tabular}


Table 6: Beaucoup Detrital Zircon U-Pb Data - 43DF15 - cont.

\begin{tabular}{|c|c|c|c|c|c|c|c|c|c|c|c|c|c|c|c|c|c|c|c|}
\hline X43DF_98 & 25.2 & 3.57 & 0.1004 & 0.0069 & 0.1572 & 3.64 & 0.27 & 0.2635 & 0.012 & 0.044218 & 1506 & 64 & 1548 & 53 & 1600 & 120 & 1600 & 120 & $94 \%$ \\
\hline X43DF_99 & 79.7 & 2.55 & 0.103 & 0.0039 & 0.49403 & 4.27 & 0.16 & 0.3044 & 0.012 & 0.79899 & 1712 & 61 & 1685 & 31 & 1674 & 70 & 1674 & 70 & $102 \%$ \\
\hline X43DF_100 & 198 & 1.396 & 0.15 & 0.013 & -0.58691 & 1.49 & 0.13 & 0.0741 & 0.0033 & 0.75201 & 461 & 20 & 916 & 52 & 2300 & 130 & 461 & 20 & $100 \%$ \\
\hline X43DF_101 & 233 & 2.6 & 0.148 & 0.011 & -0.11691 & 1.48 & 0.16 & 0.0716 & 0.0046 & 0.7457 & 445 & 28 & 918 & 65 & 2330 & 130 & 445 & 28 & $100 \%$ \\
\hline X43DF_102 & 528 & 2.45 & 0.0569 & 0.0025 & 0.51428 & 0.533 & 0.023 & 0.0668 & 0.0034 & 0.59315 & 417 & 20 & 433 & 15 & 474 & ${ }_{93}$ & 417 & 20 & $100 \%$ \\
\hline X43DF_103 & 333 & 19 & 0.0685 & 0.0032 & 0.4515 & 1.173 & 0.05 & 0.1206 & 0.0054 & 0.24816 & 734 & 31 & 787 & 23 & 883 & 96 & 734 & 31 & $100 \%$ \\
\hline X43DF_105 & 25.2 & 1.224 & 0.084 & 0.0084 & -0.10363 & 1.29 & 0.14 & 0.1045 & 0.0045 & 0.40971 & 641 & 26 & 827 & 60 & 1310 & 200 & 641 & 26 & $100 \%$ \\
\hline X43DF_106 & 63.1 & 1.208 & 0.0993 & 0.0039 & 0.3011 & 4.02 & 0.16 & 0.2834 & 0.011 & 0.56565 & 1608 & 57 & 1640 & 33 & 1613 & 68 & 1613 & 68 & $100 \%$ \\
\hline X43DF_107 & 568 & 2.68 & 0.0566 & 0.0021 & 0.1693 & 0.526 & 0.022 & 0.0667 & 0.0027 & 0.69762 & 416 & 17 & 429 & 15 & 487 & 83 & 416 & 17 & $100 \%$ \\
\hline X43DF_108 & 346 & 2.52 & 0.0562 & 0.0022 & 0.12395 & 0.511 & 0.02 & 0.066 & 0.0027 & 0.61033 & 412 & 16 & 421 & 14 & 479 & 83 & 412 & 16 & $100 \%$ \\
\hline X43DF_109 & 61.1 & 1.233 & 0.0992 & 0.0038 & 0.36452 & 3.676 & 0.14 & 0.2683 & 0.011 & 0.46243 & 1531 & 55 & 1568 & 29 & 1613 & 69 & 1613 & 69 & $95 \%$ \\
\hline X43DF_110 & 237 & 1.622 & 0.0588 & 0.0028 & 0.39433 & 0.537 & 0.023 & 0.0672 & 0.0028 & 0.30978 & 419 & 17 & 436 & 15 & 574 & 100 & 419 & 17 & $100 \%$ \\
\hline X43DF_111 & 569 & 2.499 & 0.0559 & 0.0023 & 0.3851 & 0.52 & 0.02 & 0.0675 & 0.0025 & 0.34929 & 420.9 & 15 & 426.3 & 14 & 450 & 95 & 420.9 & 15 & $100 \%$ \\
\hline X43DF_112 & 137.6 & 3.6 & 0.1901 & 0.0067 & 0.53534 & 13.93 & 0.49 & 0.531 & 0.02 & 0.58369 & 2746 & 85 & 2743 & 33 & 2740 & 57 & 2740 & 57 & $100 \%$ \\
\hline X43DF_113 & 124.1 & 1.041 & 0.0645 & 0.0031 & 0.24787 & 0.952 & 0.046 & 0.1069 & 0.0041 & 0.17309 & 655 & 24 & 682 & 22 & 740 & 100 & 655 & 24 & $100 \%$ \\
\hline X43DF_114 & 56.4 & 2.9 & 0.0579 & 0.0037 & 0.0046471 & 0.558 & 0.035 & 0.0709 & 0.0031 & 0.39839 & 441 & 19 & 449 & 23 & 490 & 140 & 441 & 19 & $100 \%$ \\
\hline X43DF_115 & 373 & 1.93 & 0.058 & 0.0026 & 0.1781 & 0.536 & 0.025 & 0.0675 & 0.003 & 0.71398 & 421 & 18 & 435 & 17 & 528 & 100 & 421 & 18 & $100 \%$ \\
\hline X43DF_116 & 523 & 2.028 & 0.0572 & 0.0025 & 0.64209 & 0.541 & 0.021 & 0.0698 & 0.0028 & 0.49111 & 435.2 & 17 & 438.9 & 14 & 486 & 93 & 435.2 & 17 & $100 \%$ \\
\hline X43DF_117 & 27.1 & 1.671 & 0.0977 & 0.01 & -0.22915 & 1.51 & 0.17 & 0.1109 & 0.0047 & 0.50776 & 678 & 28 & 913 & 71 & 1510 & 210 & 678 & 28 & $100 \%$ \\
\hline X43DF_118 & 513 & 1.97 & 0.0576 & 0.0024 & 0.21512 & 0.543 & 0.022 & 0.0685 & 0.003 & 0.5148 & 427 & 18 & 440 & 15 & 503 & 93 & 427 & 18 & $100 \%$ \\
\hline X43DF_119 & 347 & 2.73 & 0.057 & 0.0023 & 0.081207 & 0.544 & 0.024 & 0.0688 & 0.0027 & 0.48171 & 429.1 & 16 & 440 & 16 & 498 & 84 & 429.1 & 16 & $100 \%$ \\
\hline X43DF_120 & 261 & 2.074 & 0.062 & 0.0039 & -0.25529 & 0.688 & 0.056 & 0.0794 & 0.0036 & 0.61519 & 493 & 21 & 527 & 32 & 640 & 120 & 493 & 21 & $100 \%$ \\
\hline X43DF_121 & 82 & 4.98 & 0.0835 & 0.0037 & 0.55287 & 2.403 & 0.094 & 0.2087 & 0.0087 & 0.33991 & 1221 & 47 & 1246 & 30 & 1270 & 85 & 1221 & 47 & $96 \%$ \\
\hline X430F_1222 & 32.8 & 2.56 & 0.0917 & 0.0044 & 0.37934 & 3.08 & 0.15 & 0.2461 & 0.01 & 0.40462 & 1418 & 53 & 1435 & 36 & 1460 & 89 & 1460 & 89 & $97 \%$ \\
\hline X43DF_123 & 136 & 3.02 & 0.0621 & 0.0029 & 0.29793 & 1.054 & 0.054 & 0.1231 & 0.0054 & 0.51962 & 752 & 29 & 729 & 26 & 674 & 100 & 752 & 29 & $100 \%$ \\
\hline X43DF_124 & 280 & 1.374 & 0.1037 & 0.0036 & 0.065203 & 4.31 & 0.16 & 0.3052 & 0.012 & 0.69543 & 1717 & 58 & 1694 & 32 & 1696 & 60 & 1696 & 60 & $101 \%$ \\
\hline X430F_125 & 505 & 2.87 & 0.0603 & 0.0023 & 0.20633 & 0.579 & 0.027 & 0.0686 & 0.0031 & 0.7415 & 428 & 19 & 463 & 17 & 606 & 82 & 428 & 19 & $100 \%$ \\
\hline X43DF_126 & 497 & 2.32 & 0.0657 & 0.003 & 0.27516 & 0.61 & 0.028 & 0.0662 & 0.0029 & 0.47535 & 413 & 18 & 485 & 17 & 795 & 91 & 413 & 18 & $100 \%$ \\
\hline X43DF_127 & 406 & 2.22 & 0.0612 & 0.0025 & 0.1281 & 0.889 & 0.04 & 0.1042 & 0.0043 & 0.68042 & 639 & 25 & 645 & 21 & 647 & 86 & 639 & 25 & $100 \%$ \\
\hline X430F_128 & 284.7 & 1.962 & 0.0601 & 0.003 & -0.013885 & 0.537 & 0.029 & 0.0633 & 0.0025 & 0.50094 & 395.8 & 15 & 435 & 19 & 585 & 110 & 395.8 & 15 & $100 \%$ \\
\hline X43DF_129 & 435 & 17.7 & 0.0722 & 0.0029 & -0.13137 & 1.454 & 0.068 & 0.1442 & 0.0058 & 0.74185 & 868 & 33 & 909 & 28 & 984 & 82 & 868 & 33 & $88 \%$ \\
\hline X43DF_10 & 252 & 11.09 & 0.0748 & 0.0026 & 0.48474 & 1.948 & 0.068 & 0.19 & 0.0068 & 0.63724 & 1121 & 37 & 1097 & 24 & 1059 & 70 & 1121 & 37 & $106 \%$ \\
\hline X43DF_76 & 8.3 & 0.966 & 0.724 & 0.046 & 0.045731 & 26.1 & 2.2 & 0.27 & 0.019 & 0.68845 & 1539 & 97 & 3352 & 81 & 4789 & 110 & 4789 & 110 & $32 \%$ \\
\hline X43DF_104 & 114 & 2.22 & 0.1267 & 0.0048 & 0.12093 & 7.24 & 0.29 & 0.405 & 0.018 & 0.76429 & 2192 & 85 & 2139 & 34 & 2048 & 66 & 2048 & 66 & $107 \%$ \\
\hline
\end{tabular}


Table 7: Kanayut Detrital Zircon U-Pb Data - 41DF15

\begin{tabular}{|c|}
\hline \\
\hline Analysis \\
\hline WPF41_1 \\
\hline WPF41_3 \\
\hline WPF41_4 \\
\hline WPF41_5 \\
\hline WPF41_6 \\
\hline WPF41_? \\
\hline WPF41_8 \\
\hline WPF41_9 \\
\hline WPF41_10 \\
\hline WPF41_11 \\
\hline WPF41_12 \\
\hline WPF $41 \_13$ \\
\hline WPF41_14 \\
\hline WPF41_15 \\
\hline WPF41_16 \\
\hline WPF41_17 \\
\hline WPF41_18 \\
\hline WPF41_19 \\
\hline WPF41_20 \\
\hline WPF41_21 \\
\hline WPF41_22 \\
\hline WPF41_23 \\
\hline WPF41_24 \\
\hline WPF41_25 \\
\hline WPF41_26 \\
\hline WPF41_27 \\
\hline WPF41_28 \\
\hline WPF41_29 \\
\hline WPF41_30 \\
\hline WPF41_31 \\
\hline WPF41_32 \\
\hline WPF41_33 \\
\hline WPF41_34 \\
\hline WPF41_35 \\
\hline WPF41_36 \\
\hline WPF41_37 \\
\hline WPF41_38 \\
\hline WPF41_39 \\
\hline WPF41_40 \\
\hline WPF41_41 \\
\hline WPF41_42 \\
\hline WPF41_43 \\
\hline WPF41_44 \\
\hline WPF41_45 \\
\hline WPF41_46 \\
\hline WPF41_47 \\
\hline WPF41_48 \\
\hline WPF41_49 \\
\hline WPF41_50 \\
\hline WPF41_51 \\
\hline WPF41_52 \\
\hline WPF41_53 \\
\hline WPF41_54 \\
\hline WPF41_55 \\
\hline WPF41_56 \\
\hline WPF41_57 \\
\hline WPF41_58 \\
\hline WPF41_59 \\
\hline WPF41_60 \\
\hline WPF41_61 \\
\hline WPF41_62 \\
\hline WPF41_63 \\
\hline WPF41_64 \\
\hline WPF41_65 \\
\hline WPF41_66 \\
\hline WPF41_67 \\
\hline WPF41_68 \\
\hline WPF41_69 \\
\hline WPF41_70 \\
\hline WPF $41 \_71$ \\
\hline WPF41_72 \\
\hline WPF41_73 \\
\hline WPF $41 \_75$ \\
\hline WPF41_76 \\
\hline WPF41_77 \\
\hline WPF41_78 \\
\hline WPF41_79 \\
\hline WPF41_80 \\
\hline WPF41_81 \\
\hline WPF41_82 \\
\hline WPF41_83 \\
\hline WPF41_84 \\
\hline WPF41_85 \\
\hline WPF41_86 \\
\hline WPF41_87 \\
\hline WPF41_88 \\
\hline WPF41_89 \\
\hline WPF41_90 \\
\hline WPF41_91 \\
\hline WPF41_92 \\
\hline WPF41_93 \\
\hline WPF41_94 \\
\hline WPF41_95 \\
\hline WPF41_96 \\
\hline
\end{tabular}


Table 7: Kanayut Detrital Zircon U-Pb Data - 41DF15 - cont.

\begin{tabular}{|c|c|c|c|c|c|c|c|c|c|c|c|c|c|c|c|c|c|c|c|}
\hline WPF41_98 & 116 & 116 & 0.0548 & 0.0027 & 0.36776 & 0.555 & 0.031 & 0.074 & 0.0026 & 0.3837 & 460 & 15 & 451 & 21 & 387 & 110 & 460 & 15 & $100 \%$ \\
\hline WPF41_99 & 184 & 184 & 0.0786 & 0.0048 & 0.37785 & 0.573 & 0.036 & 0.0532 & 0.0016 & 0.088384 & 334.1 & 9.8 & 462 & 23 & 1130 & 120 & 334.1 & 9.8 | & $100 \%$ \\
\hline WPF41_100 & 392 & 392 & 0.0519 & 0.0022 & 0.1677 & 0.539 & 0.029 & 0.0741 & 0.0021 & 0.25834 & 460.8 & 12 & 433 & 19 & 272 & 93 & 460.8 & 12 & $100 \%$ \\
\hline WPF41_101 & 67.5 & 67.5 & 0.0488 & 0.0038 & 0.19433 & 0.402 & 0.032 & 0.0594 & 0.002 & -0.070142 & 371.7 & 12 & 341 & 23 & 130 & 150 & 371.7 & 12 & $100 \%$ \\
\hline WPF41_103 & 60 & 60 & 0.0495 & 0.0041 & 0.39296 & 0.496 & 0.043 & 0.0742 & 0.0028 & 0.029715 & 461 & 17 & 412 & 29 & 190 & 170 & 461 & 17 & $100 \%$ \\
\hline WPF41_104 & 50.2 & 50.2 & 0.0641 & 0.008 & 0.10255 & 0.64 & 0.076 & 0.0722 & 0.0025 & 0.18123 & 449 & 15 & 494 & 46 & 650 & 250 & 449 & 15 & $100 \%$ \\
\hline WPF41_105 & 148.2 & 148.2 & 0.0548 & 0.0023 & 0.39644 & 0.525 & 0.027 & 0.0687 & 0.002 & 0.2415 & 428.4 & 12 & 430 & 17 & 406 & 100 & 428.4 & 12 & $100 \%$ \\
\hline WPF41_106 & 588 & 588 & 0.0545 & 0.0021 & 0.27728 & 0.508 & 0.027 & 0.0656 & 0.0021 & 0.51909 & 409.5 & 13 & 417 & 18 & 382 & 88 & 409.5 & 13 & $100 \%$ \\
\hline WPF41_107 & 191 & 191 & 0.054 & 0.0024 & -0.12324 & 0.553 & 0.036 & 0.0734 & 0.0027 & 0.49831 & 457 & 16 & 445 & 24 & 354 & 100 & 457 & 16 & $100 \%$ \\
\hline WPF41_108 & 47.3 & 47.3 & 0.048 & 0.0044 & 0.23133 & 0.477 & 0.05 & 0.0716 & 0.0025 & 0.010183 & 445 & 15 & 393 & 34 & 130 & 190 & 445 & 15 & $100 \%$ \\
\hline WPF41_109 & 142 & 142 & 0.0581 & 0.0036 & 0.061101 & 0.552 & 0.044 & 0.0679 & 0.0024 & 0.34294 & 424 & 15 & 444 & 28 & 490 & 130 & 424 & 15 & $100 \%$ \\
\hline WPF41_110 & 790 & 790 & 0.0563 & 0.0019 & 0.18943 & 0.542 & 0.028 & 0.0701 & 0.0025 & 0.76168 & 436 & 14 & 439 & 19 & 458 & 77 & 436 & 14 & $100 \%$ \\
\hline WPF41_111 & 141.8 & 141.8 & 0.1153 & 0.0044 & 0.453 & 5.28 & 0.24 & 0.3275 & 0.011 & 0.59162 & 1825 & 55 & 1864 & 41 & 1876 & 74 & 1876 & 74 & $97 \%$ \\
\hline WPF41_112 & 52.6 & 52.6 & 0.0592 & 0.0046 & -0.013661 & 0.593 & 0.053 & 0.0712 & 0.0024 & 0.30152 & 443 & 14 & 469 & 34 & 580 & 180 & 443 & 14 & $100 \%$ \\
\hline WPF41_113 & 490 & 490 & 0.055 & 0.0024 & 0.20207 & 0.539 & 0.03 & 0.0704 & 0.0027 & 0.53825 & 438 & 16 & 437 & 20 & 396 & 98 & 438 & 16 & $100 \%$ \\
\hline WPF41_114 & 67 & 67 & 0.0562 & 0.0038 & 0.48564 & 0.491 & 0.033 & 0.0623 & 0.0022 & -0.033385 & 390 & 13 & 404 & 21 & 480 & 150 & 390 & 13 & $100 \%$ \\
\hline WPF41_15 & 165 & 165 & 0.0541 & 0.0027 & 0.091987 & 0.516 & 0.034 & 0.0685 & 0.0023 & 0.33628 & 427 & 14 & 421 & 23 & 354 & 110 & 427 & 14 & $100 \%$ \\
\hline WPF41_116 & 83.7 & 83.7 & 0.0733 & 0.005 & 0.25901 & 0.731 & 0.052 & 0.0711 & 0.0032 & 0.22446 & 443 & 19 & 553 & 35 & 970 & 150 & 443 & 19 & $100 \%$ \\
\hline WPF41_117 & 81.9 & 81.9 & 0.1637 & 0.0054 & 0.39209 & 10.92 & 0.51 & 0.476 & 0.016 & 0.66715 & 2507 & 69 & 2519 & 41 & 2497 & 57 & 2497 & 57 & $100 \%$ \\
\hline WPF41_118 & 45.1 & 45.1 & 0.0576 & 0.006 & 0.021933 & 0.557 & 0.061 & 0.0693 & 0.0022 & 0.13247 & 432 & 13 & 433 & 39 & 380 & 180 & 432 & 13 & $100 \%$ \\
\hline WPF41_119 & 84.2 & 84.2 & 0.0611 & 0.0043 & 0.10623 & 0.566 & 0.041 & 0.0681 & 0.0021 & 0.14273 & 424.7 & 12 & 453 & 26 & 560 & 130 & 424.7 & 12 & $100 \%$ \\
\hline WPF41_120 & 74.3 & 74.3 & 0.0581 & 0.0042 & 0.32474 & 0.548 & 0.04 & 0.0674 & 0.0026 & -0.17092 & 420 & 16 & 442 & 26 & 480 & 150 & 420 & 16 & $100 \%$ \\
\hline WPF41_121 & 195 & 195 & 0.0818 & 0.0029 & 0.44322 & 1.824 & 0.089 & 0.1606 & 0.0051 & 0.57975 & 960 & 28 & 1053 & 33 & 1233 & 75 & 960 & 28 & $78 \%$ \\
\hline WPF41_122 & 38.2 & 38.2 & 0.0534 & 0.0037 & 0.46485 & 0.506 & 0.036 & 0.0676 & 0.0028 & 0.068867 & 422 & 17 & 414 & 24 & 310 & 150 & 422 & 17 & $100 \%$ \\
\hline WPF41_123 & 218 & 218 & 0.0576 & 0.0024 & 0.35939 & 0.597 & 0.031 & 0.0746 & 0.0024 & 0.31303 & 464 & 15 & 477 & 20 & 514 & 110 & 464 & 15 & $100 \%$ \\
\hline WPF41_124 & 85.5 & 85.5 & 0.0621 & 0.0048 & -0.015428 & 0.612 & 0.055 & 0.0711 & 0.0022 & 0.18085 & 443 & 13 & 472 & 34 & 610 & 160 & 443 & 13 & $100 \%$ \\
\hline WPF41_125 & 298 & 298 & 0.0574 & 0.0021 & 0.26815 & 0.461 & 0.024 & 0.0578 & 0.002 & 0.57022 & 362 & 12 & 385 & 16 & 512 & 89 & 362 & 12 & $100 \%$ \\
\hline WPF41_126 & 42.7 & 42.7 & 0.0592 & 0.0049 & 0.22618 & 0.58 & 0.057 & 0.0682 & 0.0028 & 0.088715 & 425 & 17 & 459 & 36 & 550 & 190 & 425 & 17 & $100 \%$ \\
\hline WPF41_127 & 363 & 363 & 0.0612 & 0.0027 & -0.0666644 & 0.564 & 0.033 & 0.0659 & 0.0023 & 0.66773 & 411 & 14 & 453 & 22 & 641 & 110 & 411 & 14 & $100 \%$ \\
\hline WPF41_128 & 67.9 & 67.9 & 0.0627 & 0.0044 & 0.026413 & 0.552 & 0.042 & 0.0638 & 0.0021 & 0.29122 & 399 & 13 & 444 & 30 & 670 & 160 & 399 & 13 & $100 \%$ \\
\hline WPF41_129 & 72 & 72 & 0.0556 & 0.0029 & 0.1052 & 0.444 & 0.028 & 0.0572 & 0.0018 & 0.29143 & 358.5 & 11 & 376 & 18 & 470 & 110 & 358.5 & 11 & $100 \%$ \\
\hline WPF41_130 & 91 & 91 & 0.0575 & 0.003 & 0.52536 & 0.532 & 0.03 & 0.0678 & 0.0023 & -0.10593 & 423 & 14 & 433 & 20 & 510 & 110 & 423 & 14 & $100 \%$ \\
\hline WPF41_2 & 9.7 & 9.7 & 0.668 & 0.03 & -0.30799 & 32.5 & 4.4 & 0.347 & 0.039 & 0.87528 & 1890 & 190 & 3500 & 160 & 4663 & 69 & 4663 & 69 & $41 \%$ \\
\hline WPF41_102 & 55.4 & 55.4 & 0.1077 & 0.004 & 0.34662 & 5.06 & 0.25 & 0.334 & 0.0096 & 0.42719 & 1857 & 46 & 1832 & 42 & 1756 & 69 & 1756 & 69 & $106 \%$ \\
\hline
\end{tabular}


Table 8: Hunt Fork Detrital Zircon U-Pb Data - 26DF15

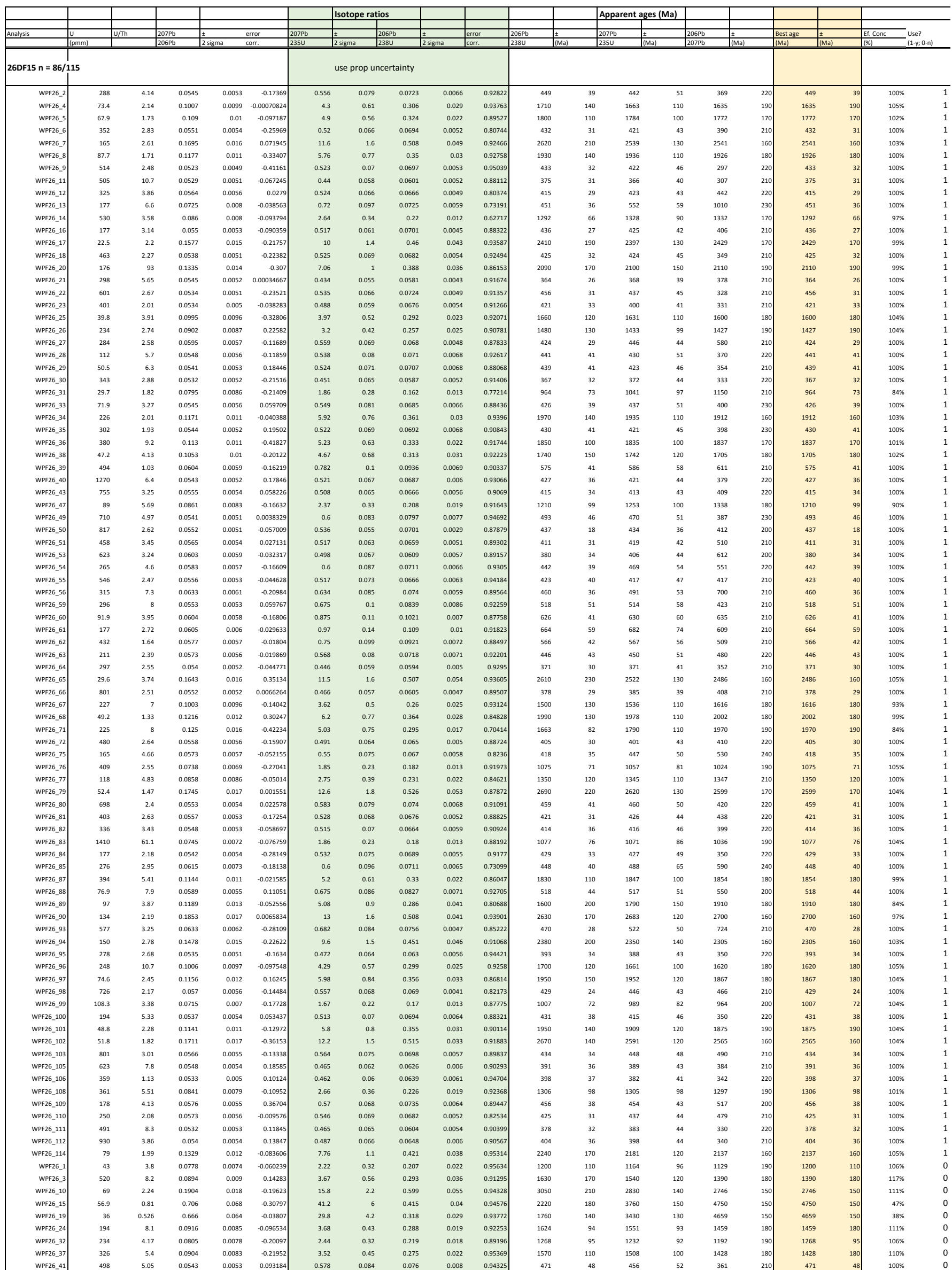


Table 8: Hunt Fork Detrital Zircon U-Pb Data - 26DF15 - cont.

\begin{tabular}{|c|c|c|c|c|c|c|c|c|c|c|c|c|c|c|c|c|c|c|c|}
\hline WPF26_42 & 236 & 12.5 & 0.0699 & 0.0067 & 0.0048951 & 1.63 & 0.23 & 0.169 & 0.016 & 0.93741 & 1018 & 95 & 975 & 88 & 908 & 200 & 1018 & 95 & $112 \%$ \\
\hline WPF26_44 & 141 & 6.9 & 0.1179 & 0.011 & 0.014669 & 6.06 & 0.84 & 0.371 & 0.034 & 0.93432 & 2010 & 160 & 1947 & 120 & 1910 & 170 & 1910 & 170 & $105 \%$ \\
\hline WPF26_45 & 2.83 & 0.392 & 0.685 & 0.072 & 0.34201 & 42.9 & 7.3 & 0.44 & 0.064 & 0.92402 & 2370 & 300 & 3780 & 170 & 4700 & 170 & 4700 & 170 & $50 \%$ \\
\hline WPF26_46 & 188 & 2.37 & 0.0549 & 0.0054 & -0.03738 & 0.562 & 0.086 & 0.0721 & 0.0081 & 0.93201 & 447 & 48 & 444 & 54 & 400 & 230 & 447 & 48 & $100 \%$ \\
\hline WPF26_48 & 126 & 2.74 & 0.0754 & 0.0074 & 0.077172 & 2.13 & 0.3 & 0.209 & 0.023 & 0.90531 & 1210 & 120 & 1150 & 97 & 1076 & 200 & 1210 & 120 & $112 \%$ \\
\hline WPF26_52 & 123 & 3.08 & 0.1122 & 0.011 & 0.28645 & 5.54 & 0.73 & 0.351 & 0.034 & 0.90189 & 1920 & 160 & 1875 & 110 & 1817 & 180 & 1817 & 180 & $106 \%$ \\
\hline WPF26_57 & 46.5 & 2.66 & 0.0897 & 0.009 & 0.061731 & 3.27 & 0.47 & 0.261 & 0.027 & 0.91783 & 1480 & 130 & 1440 & 110 & 1397 & 190 & 1397 & 190 & $106 \%$ \\
\hline WPF26_58 & 51.6 & 0.54 & 0.689 & 0.068 & -0.022985 & 44.6 & 7.1 & 0.434 & 0.048 & 0.94319 & 2300 & 210 & 3830 & 160 & 4711 & 150 & 4711 & 150 & $49 \%$ \\
\hline WPF26_69 & 118 & 5.81 & 0.0866 & 0.0083 & -0.21 & 3.22 & 0.42 & 0.277 & 0.024 & 0.9273 & 1570 & 120 & 1451 & 100 & 1349 & 190 & 1349 & 190 & $116 \%$ \\
\hline WPF $26 \_70$ & 555 & 8.1 & 0.0823 & 0.008 & -0.12986 & 2.76 & 0.39 & 0.243 & 0.024 & 0.92152 & 1390 & 120 & 1349 & 110 & 1236 & 180 & 1390 & 120 & $112 \%$ \\
\hline WPF26_73 & 57.5 & 0.65 & 0.499 & 0.05 & -0.10482 & 19.8 & 3.1 & 0.278 & 0.032 & 0.90299 & 1600 & 170 & 3040 & 150 & 4224 & 140 & 4224 & 140 & $38 \%$ \\
\hline WPF26_74 & 51 & 6.5 & 0.0548 & 0.0055 & -0.039162 & 0.579 & 0.087 & 0.0754 & 0.0082 & 0.89593 & 467 & 49 & 464 & 57 & 420 & 240 & 467 & 49 & $100 \%$ \\
\hline WPF26_78 & 201 & 6.5 & 0.0623 & 0.0065 & -0.21841 & 0.722 & 0.12 & 0.0798 & 0.0084 & 0.87463 & 493 & 50 & 538 & 67 & 660 & 230 & 493 & 50 & $100 \%$ \\
\hline WPF26_86 & 167 & 5.1 & 0.0724 & 0.0072 & -0.19805 & 1.74 & 0.26 & 0.173 & 0.017 & 0.92932 & 1025 & 95 & 1000 & 98 & 972 & 200 & 1025 & 95 & $105 \%$ \\
\hline WPF26_91 & 235 & 15.3 & 0.0703 & 0.0069 & -0.23072 & 1.67 & 0.24 & 0.172 & 0.015 & 0.91287 & 1018 & 84 & 975 & 86 & 915 & 200 & 1018 & 84 & $111 \%$ \\
\hline WPF26_92 & 413 & 29 & 0.0695 & 0.0068 & -0.26981 & 1.79 & 0.24 & 0.182 & 0.014 & 0.90226 & 1071 & 76 & 1022 & 85 & 892 & 210 & 1071 & 76 & $120 \%$ \\
\hline WPF26_104 & 236 & 5.3 & 0.0968 & 0.0094 & -0.11888 & 4.18 & 0.58 & 0.313 & 0.03 & 0.93381 & 1740 & 150 & 1650 & 110 & 1560 & 180 & 1560 & 180 & $112 \%$ \\
\hline WPF26_107 & 269 & 3.43 & 0.084 & 0.018 & -0.16098 & 0.9 & 0.25 & 0.0728 & 0.0096 & 0.58705 & 452 & 58 & 630 & 120 & 1240 & 380 & 452 & 58 & $100 \%$ \\
\hline WPF26_113 & 280 & 6.2 & 0.1075 & 0.011 & 0.14762 & 5.15 & 0.71 & 0.335 & 0.032 & 0.91371 & 1880 & 160 & 1810 & 120 & 1752 & 180 & 1752 & 180 & $107 \%$ \\
\hline WPF26_115 & 322 & 5.5 & 0.0573 & 0.0058 & 0.11032 & 0.572 & 0.09 & 0.0691 & 0.008 & 0.8962 & 429 & 48 & 449 & 56 & 490 & 230 & 429 & 48 & $100 \%$ \\
\hline
\end{tabular}

